

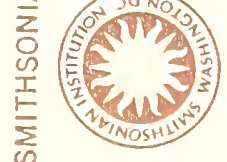

minament
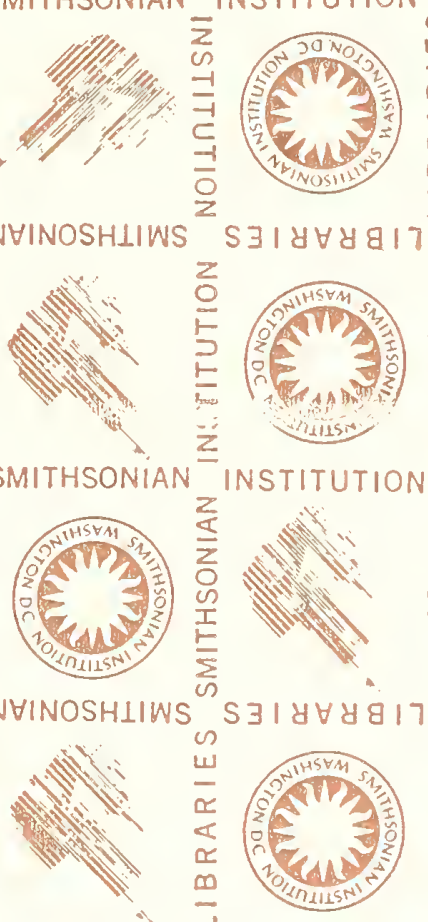

andent
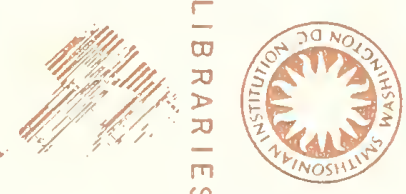

S S 31 바익

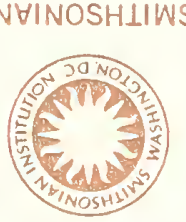

SMITHSONIAN
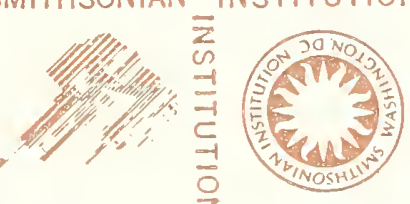

S $\exists 14 \forall 4817$

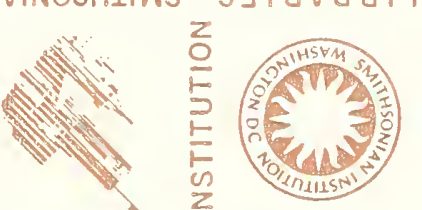

SMITHSONIAN INSTITUTION
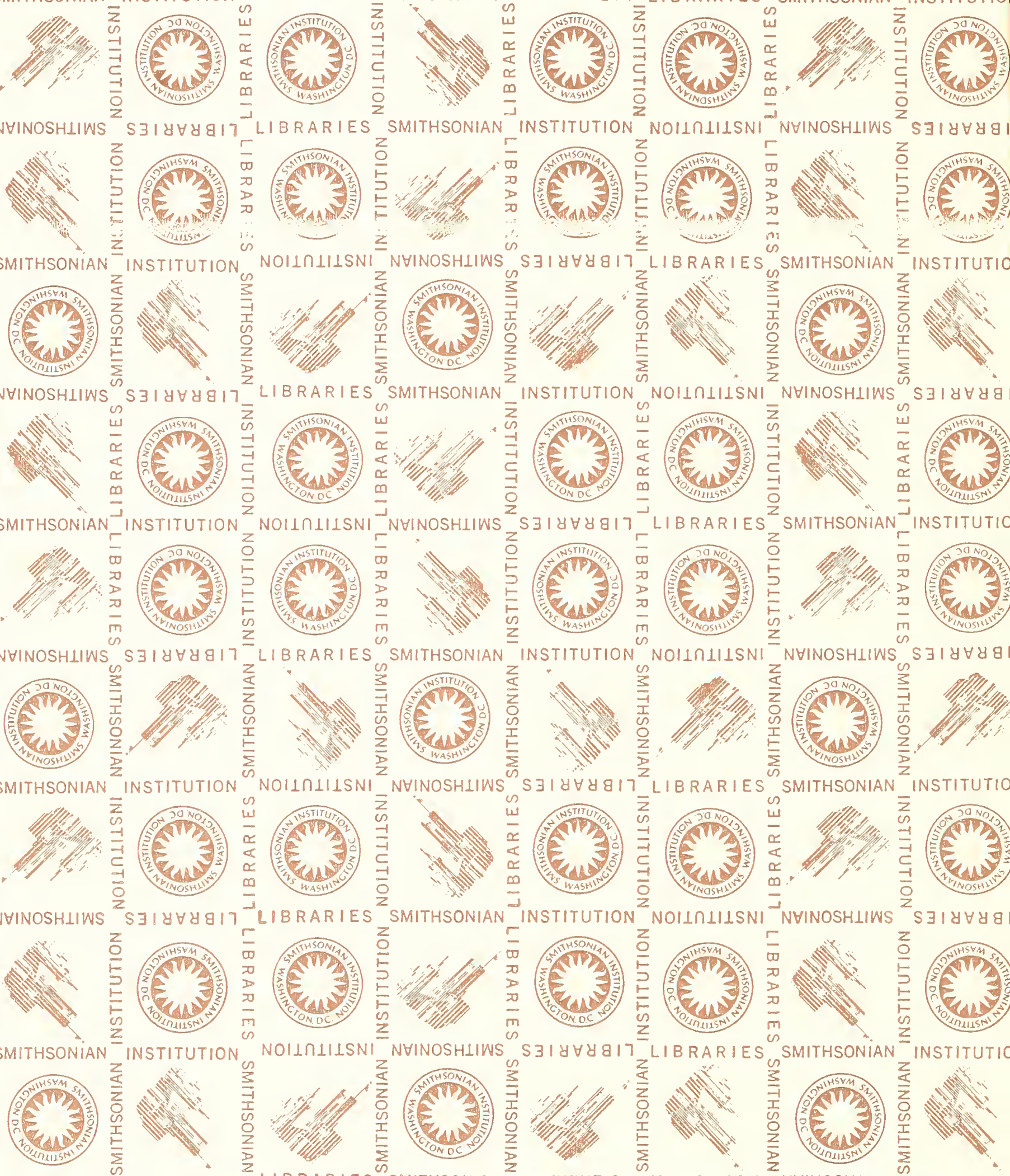

NOIIOLILSNI NVINOSHLIWS
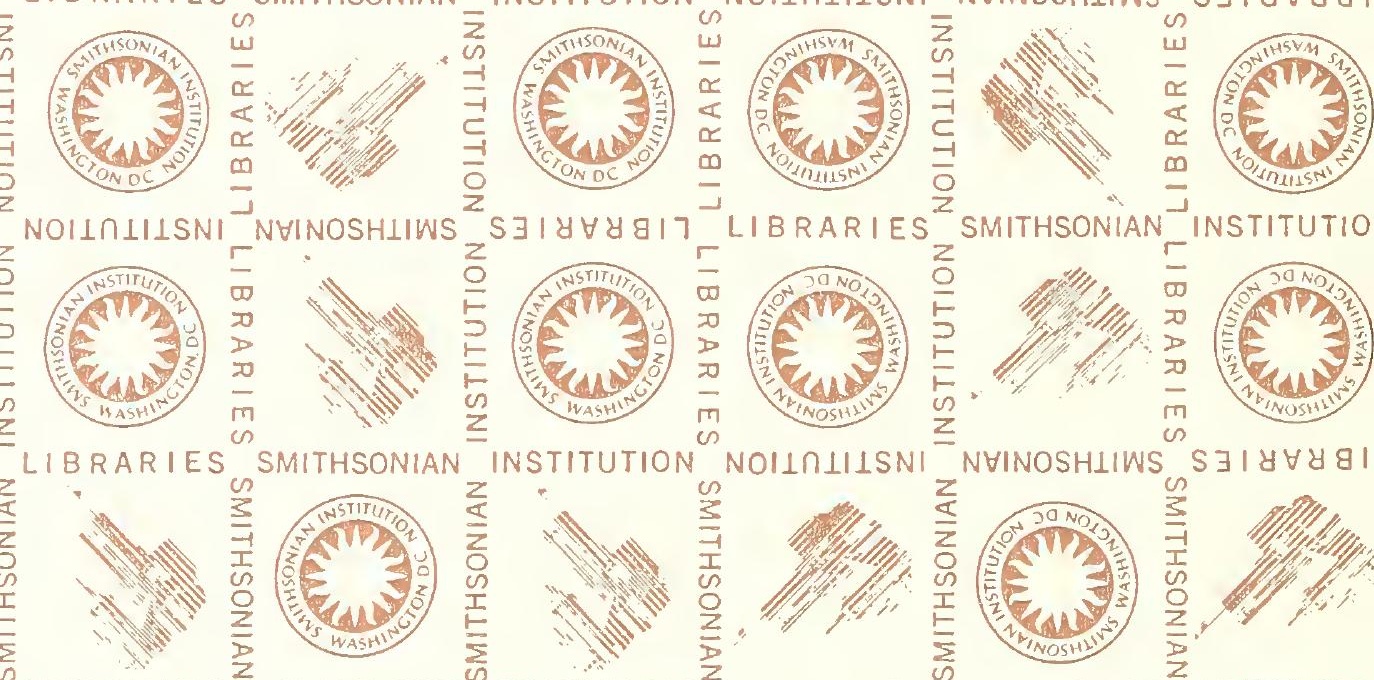

告
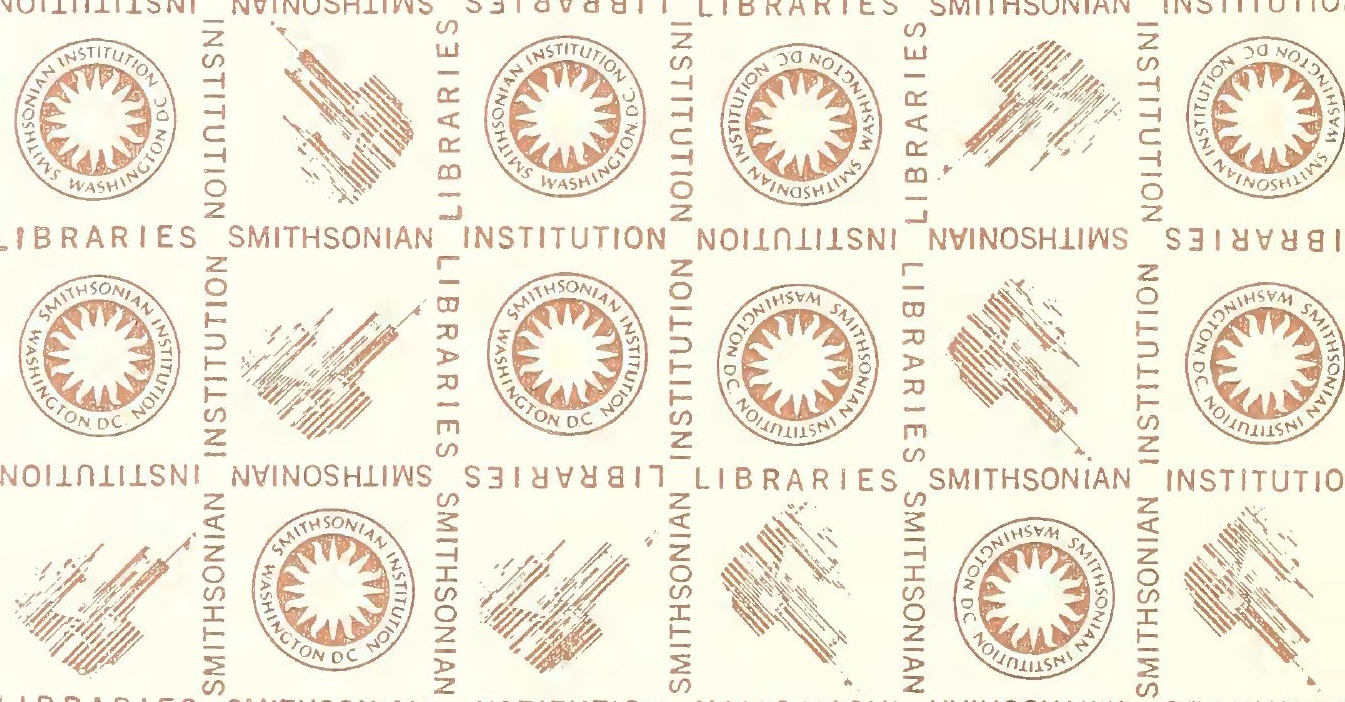
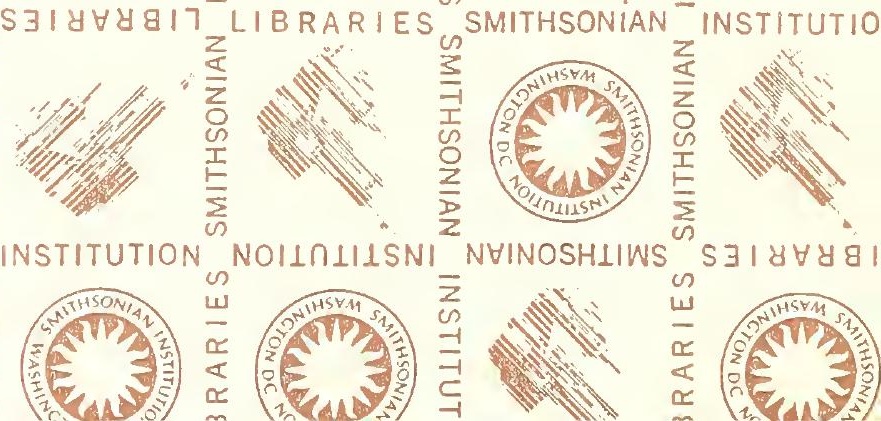



. 


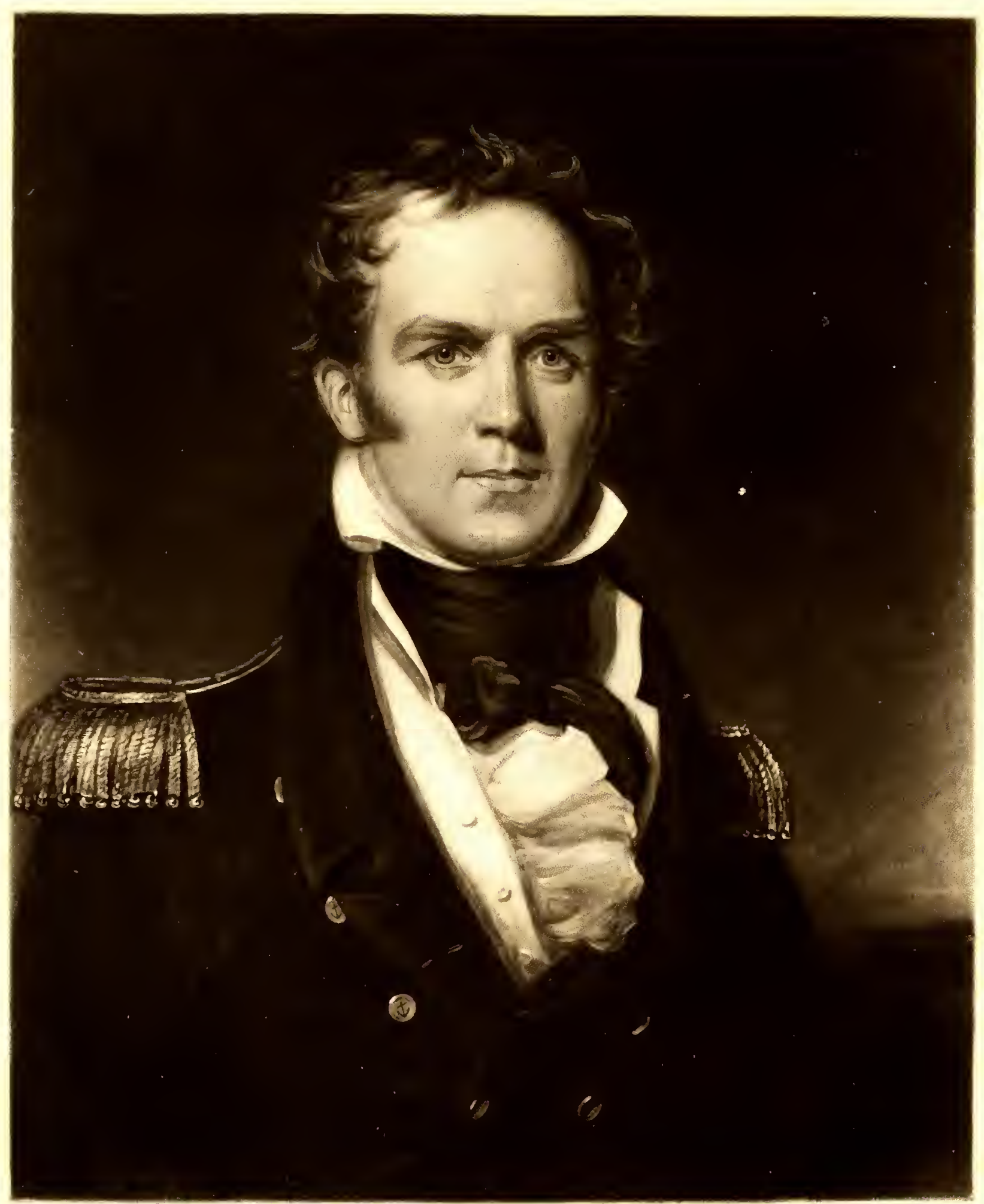


J O U R N A L

of A

\section{SECOND EXPEDITION}

INTO THE

\section{INTERIOR OF AFRICA,}

FROM

\section{THE BIGHT OF BENIN TO SOCCATOO.}

\section{BY THE LATE COMMANDER CLAPPERTON,}

OF THE ROYAL NAVY.

TO WHICH IS ADDED,

THE JOURNAL OF RICHARD LANDER FROM KANO TO THE SEA-COAST, PARTLY BY A MORE EASTERN ROUTE.

WITI

A PORTRAIT OF CAPTAIN CLAPPERTON, AND A MAP OF THE ROUTE,

CHIEFLY LAID DOWN FROM ACTUAL OBSERVATIONS FOR IATITUDE AND LONGITUDE.

\section{LONDON :}

JOHN MURRAY, ALBEMARLE-STREET.

$\overrightarrow{\text { IDCCCXXIX. }}$ 



\section{SHORT SKETCH}

OF THE

\section{FE O F CAPTAIN CLAPPERTON.}

BY LIEUTENANT-COLONEL CLAPPERTON.

Captain Hugh Clapperton was born in Annan, Dumfries-shire, in the year 1788. His grandfathcr, Robert Clapperton, M. D., was a man of considerable knowledge, as a classical scholar, and in his profession. He first studied at Edinburgh ; but as, in those days, the continental colleges were considered superior in medicine and surgery, he went to Paris, and there studied for some time. On his return to his native country, he married Elizabeth Campbell, second cousin of Colonel Archibald Campbell of Glenlyon; and soon after settled in Dumfries-shire, at a place called Crowden Nows, where he remained until George Clapperton (the father of our traveller), and another son were born. He afterwards removed to Lochmaben, where he had an increase to his family of four sons and one daughter. All the sons became medical men, except the youngest and the only survivor, who entered his Majesty's service, in the beginning of 1793, as a second lieutenant of marines. His eldest son, George Clapperton, married young to a daughter of John Johnstone, proprietor of the lands of Thorniwhate and Lochmaben Castle, and settled in Annan, where he was a considerable time the only medical man of repute in the place, and performed many operations and cures which spread his fame over the borders of England and Scotland. His father bestowed a good education upon him, which proved so useful a passport to public favour, that he might have made a fortune; but, unfortunately, he was, like his father, careless of money. He married a second wife, and was the father of no fewer than twenty-one children. Of the fruit of the first marriage, he had six sons and one daughter who grew to men and women's estate. All the sons entered his Majesty's service, the youngest of whom was Captain Clapperton, the African traveller, and the subject of this memoir. In his person he rescmbled his father greatly, but was not so tall by two inches, being five feet eleven inches; had great breadth of chest and expansion of shoulders, and otherwise proportionably strong; and 
was a handsome, athletic, powerful man. He rceived no classical education, and could do little more than read and write, when he was put under the tuition of $\mathrm{Mr}$. Bryce Downie, a man of gcneral knowledgc, but chiefly celebrated for his mathematical abilities. He remained with Mr. Downie until he required a knowledge of practical mathematics, including navigation and trigonometry. He was found an apt scholar and an obliging boy by Mr. Downie, whose attention was never forgot by the traveller; as he expressed a great wish, when he arrived the first journey from Africa, that he could have had time to see his native country, and shakc his old master once more by the hand. Captain Clapperton left Mr. Downie about the age of thirteen; when, by his own wish, he was bound an apprentice to the owner of a vessel of considerable burthen, trading bctween Livcrpool and North America. After making sercral voyages in that vessel, he cither left her, or was impressed into his Majesty's service, and was put on board a T'ender then lying at Liverpool, which vessel carried him round to Plymouth, where he with others were draughted on board of his Majesty's ship Gibraltar, of cighty guns. He did not remain long in that ship, as in $\mathbf{1 8 0 6}$ he arrived at Gibraltar in a naval transport; from which he was impressed, witl others, on board his Majesty's frigate Renommée, Captain Sir Thomas Livingston. Opportunely for our traveller, at that time his Majesty's ship Saturn, Captain Lord Amelias Beauclere (belonging to Lord Collingwood's Hcet off Cadiz), arrived for the purpose of watering and refitting; and our traveller, learning that his uncle (now Lieut..Col. Clapperton) was captain of royal marines on board the Saturn, sent him a letter describing his situation in the Renommée. The uncle having been an old messmate of Sir Thomas's, when both were lieutenants at the Cape of Good Hope many years beforc, made it his business immediately to see Sir 'Thomas; and, through his intercession, Sir Thomas very kindly put our traveller, for the first time, upon the quarter-deck as a midshipman. The Renommée very soon aftcr left Gibraltar for the Mediterranean; and, when on the coast of Spain, had occasion to send boats to attack some enemy's vessels on shore. Clapperton, being in one of the boats, was slightly, as he considered it, wounded in the head, which, however, afterwards gave him much annoyance. He remained in the Renommée, with Sir Thomas, until she returned to England, and was paid off, in the year 1808. He then joined his Majesty's ship Venerable, Captain King, in the Downs, as a midshipman, where he did not remain long, having heard that Captain Briggs was going to the East Indies in the Clorinde frigate, and wishing to go to that country, he applied for his discharge, that he might enter with Captain Briggs; but he could not accomplish it before the Clorinde had sailed from Portsmouth; he was ordered, however, (by the admiral) to have a passage in a ship going to the East Indies. In the course of the voyagc, they fell in with a ship in great distress, it then blowing a gale of wind; but humanity required assistance, if it could be given. A boat was ordered to be got ready, and Clapperton to go in her. $\mathrm{He}$ declared to his messmates his decided opinion that the boat could not possibly live in the 
sea that was then running, but that it was not for him to question the orders of his superior officer. On pushing off, he told his messmates to share equally among them any artieles belonging to him, and bade them good bye. The boat had scarcely put off from the ship when she swamped, and as no assistanee eould be rendered, all hands perished, with the exeeption of two; one of whom was Clapperton, who, under such trying cireumstanees, encouraged and assisted his only surviving eompanion till his own strength failed him. Among others, he had previously struggled hard to save a warrant officer ; but finding himself nearly exhausted, he was obliged to desist, and he perished. They then dropped off, one after the other, until the bowman and Clapperton were the only two remaining out of the whole boat's erew. The latter then made use of a eommon sea expression to the bowman, "Thank God, I am not the Jonah!" meaning that he was not, by his bad eonduet in life, the cause of the Almighty visiting them with his vengeance. The bowman seconded him in the exclamation, and they kept eheering each other until the gale so far abated, that another boat was got out and sent to their relief.

They then proceeded upon their voyage; and in Mareh, 1810, Clapperton joined his majesty's ship Clorinde, where he reeeived the greatest attention from Captain Briggs during the time he was on board. In 1812, when lying in Bombay harbour, he was joined by another messmate, the Hon. F. Maekenzie, youngest son of the late Lord Seaforth, between whom a most sincere friendship was eontracted. Not long after this, $\mathrm{Mr}$. Markenzie was attaeked with a severe illness, on which oceasion Clapperton never left him, but nursed him as he would his own brother, until he died; when he added a loek of his hair to his locket, which eontained that of his father and some friends. He returned to England in the end of 1813 , or beginning of 14 ; and he was then sent, with some other intelligent midshipmen, to Portsmouth dock-yard, for the purpose of being instructed in Angelo's sword exercise, in which he afterwards exeelled. When these midshipmen were distributed to the different ships in the fleet as drill-masters, Clapperton volunteered his serviees for the Canadian lakes, and was sent on board Sir Alexander Cochrane's flag ship, the Asia. This ship eontinued at Spithead till the end of January, 1814. During the passage to Bermudas, Clapperton's services as a drill were performed on the quarter-deck. On her arrival, he was sent to Halifax, and from thenee to the lakes, just then about to become the seene of warlike operations. During his passage ont and his stay at Bermuda, nothing eould exeeed his diligence in the diseharge of his duty with the officers and men. At his own and the other mess-tables, he was the soul and life of the party: he eould sing a good song, tell humorous tales, and his eonversation was extremely amusing. He bade adieu to all on board the Asia, and pursued his voyage to Halifax ; from that to Upper Canada.

Soon after he arrived on the lakes, in 1815 , he was plaeed in a situation that strongly marked that benevolenee which was so strong a feature in lis elaracter. In the winter he was in eommand of a bloekhouse on Lake Huron, with a party of men, for the purpose 
of defending it: he had only one small gun for its defence; he was attacked by an American schooner; the blockhouse was soon demolished by the superiority of the enemy's fire; and he found that himself and the party must either become prisoners of war, or form the resolution of immediately crossing Lake Michigan upon the ice, a journey of nearly sixty miles, to York, the capital of Upper Canada, and the nearest British depôt. Notwithstanding the difficulty and danger attending a journey of such length over the ice in the depth of wintcr, the altcrnative was soon adopted, and the party set out to cross the lake, but had not gone more than ten or twelve miles, before a boy, one of the party, was unable to proceed from the cold; every one of the sailors declared that they werc unable to carry him, as they wcre so benumbed with the cold, and had scarcely strength sufficient to support themselves. Clapperton's generous naturc could not bear the idea of a fellow-creature being lcft to perish under such appalling circumstances, for a dreadful snow-storm had commenced; he therefore took the boy upon his back, holding him with his left hand, and supporting himself from slipping with a staff in his right. In this manner he continued to go forward for eight or nine miles, when he perceived that the boy relaxed his hold; and on Clapperton examining the cause, he found that the boy was in a dying statc from the cold, and he soon after expired. The sufferings of the whole party were great before they reached York; the stockings and shocs completcly worn off their feet; their bodies in a dreadful state from the want of nourishment, they having nothing during the journcy except one bag of meal. From the long inaction of Clapperton's left hand, in carrying the boy upois his back, he lost, from the effects of the frost, the first joint of his thumb.

Not long after this, Sir Edward Owen was appointed to the command upon the lakes. A short time after his arrival, he gave to Clapperton an acting order as a lieutenant, and appointed him to the Confiance. While belonging to this ship, he often made excursions on shore, with his gun, into the woods, for the purpose of getting a little fresh meat. In these cxcursions he cultivated an acquaintance with the aborigincs of the forest, and was much charmed with their mode of life, Hc had sent to his uncle in England the acting order which Sir Edward Owen had given him, that it might be laid before the Board of Adniralty for their confirmation; but, unfortunately, a very large promotion had taken place a little before his acting order came to England, and the Board declined confirming his commission. No sooner was he made acquainted with its ill success, than he formed the idea of quitting his Majesty's service altogether, and becoming one of the inhabitants of the North Amcrican forcsts. Fortumately for him, he some time afterwards abandoned that idea.

While the Confiance was at anchor ncar the shores of the Lake, Clapperton often went on shore to dinner and other parties. When he thought it time to return on board, he never employed a boat; being an expert swimmer, he plunged into the water with his clothes on, and swam along-side of the vessel; but this mode of procecding very nearly 
lost him his life. One night he was so exhausted, that he could scarcely make the people on board hear his crics : they got a boat ready, and, as he was on the point of sinking, they picked him up, and took him on board; but he never tried the same method of getting on board again.

About the end of 1816, Sir Edward Owen returned to England, and was the means of Clapperton's commission being confirmed by the Board of Admiralty. And in the year 181\%, when our vessels on the Canadian lakes were paid off and laid up, Lieutenant Clapperton returned to England, and, like many more, was put on half-pay. He went then to Edinburgh, where he remained a short time, and was introduced to the amiable mother of his beloved friend, Mr. Mackenzie, who died at Bombay. He afterwards retired to Lochmaben in 1818, and lived with an aged sister of his beloved mother's, at the abode for many years of his grandfather. Here he continued to amuse himself with rural sports until 1820, when he went to Edinburgh, and there became acquainted with Dr. Oudney, who mentioned to him the offer that had been made to employ him in a mission to the interior of Africa. This was an opening, to Clapperton's enterprising mind, not to be resisted; he immediately cntreated that he might accompany the doctor, and his offer was accepted. Dr. Oudney was told by a friend that knew Lieutenant Clappcrton wcll, that, in all varieties, and under every circumstance, however trying, he would find him a steady and faithful friend, and that his powerful and athletic form, and excellent constitution, had never been surpassed. This person was a medical man, and was so confirmed in the opinion that Clapperton, from the strength of his constitution, could not fall a sacrifice to disease, that, until the arrival of Clapperton's scrvant, Richard Lander, from his last and fatal expedition, he would not (like many more who knew Clapperton) belicre the report of his death in any way but by accident.

In the highest spirits, Lieutenant Clapperton left Edinburgh, where he had been for a short time with his sister and other rclations. Before his departure, he was introduced by Lady Seaforth (the mothcr of his friend Mackenzie) to a distinguished countryman, the author of the Man of Feeling. Clapperton's spirits were clated, and he left Edinburgh and his relations with the highest hopes. He returned to England, and was made a commander in June 2?, 1895; and before he could finish for the press an account of his former journey, he was cngaged again, by Lord Bathurst, for a second mission, by the way of the western coast of Africa, near the Bight of Bcnin. He sailed from Portsmouth in his Majesty's sloop Brazen, commanded by Captain WVillis; and was accompanied by Doctor Dickson, Captain Pearce, and Doctor Morrison. They called at Sierra Leone; from that to Bcnin, where they landed; but Dr. Dickson landed near IVhida, and proceeded by the way of Dahomy. Captains Clapperton, Pearce, and Dr. Morrison, pushed their way up the country; but they were soon attacked with disease, and Captain Pearce and Doctor Morrison died, as did also Columbus, the former 
servant of Lieut.-Col. Denham. Captain Clapperton and his servant, Richard Lander, accompanied by Mr. Houtson, a British resident at Benin, procceded across the mountains to Katunga, where Mr. Houtson left them to return to the coast, wherc he shortly afterwards died. Dr. Dickson reached Dahomey, and proceeded on his way to join Clapperton, but has not since been heard of. Captain Clapperton, with his servant, Lander, and a native black of Houssa, reached Soccatoo in safety, where thcy remained many months; but at last the captain was seized witl a fever and dysentery, which terminated his existence, and was buried, by his faithful scrvant, four miles south-east of Soccatoo, at a village called Chungary, April 13, $182 \%$

Thus perished, in the bloom of life, an officer beloved and respected by those of his profession who were acquainted with him; a man of a daring and enterprising spirit; and one who, for humanity and active benevolence, could be surpassed by none. 


\section{N T RODUCTIO N.}

When the late Captain Clapperton made his way to Soccatoo for the first time, in the year 1824, he received the most flattering attentions, and every mark of kindness, from Bello, the sultan of the Fellans, as they call themselves, or Fellatas, as they are called by the people of Soudan. This chieftain may be said to rule over almost the whole of that part of North Africa which is distinguished by the name of Houssa, though he appears to have lost a considerable portion of what his father, Hatman Danfodio, first overran; and many of the petty chiefs still continue in a state of rebellion, some of them within a day's journey of his capital. In the course of frequent conversations held with this chief, at his usual residence of Soccatoo, Clapperton was given to understand, that the establishment of a friendly intercourse with England would be most agreeable to him; that he wished particularly for certain articles of English manufacture to be sent out to him to the sea-coast, where there was a place of great commerce belonging to him, named Funda: he also expressed a wish that an English physician and a consul should be appointed to reside at another sea-port, called Raka; to the former of which places, he said, he would despatch messengers to bring up the articles from England; and to the latter he would send down a proper person to transact all matters of business between the two governments, through the intervention of the English consul; and he made no difficulty in declaring his readiness to adopt measures for putting an entire stop to that part of the slave-trade supposed to be carried on by his subjects with foreigners.

On the arrival of Clapperton in England, Lord Bathurst, then secretary of state for the colonies, considering this so favourable an opportunity of establishing an intercourse with the interior of Africa, and probably of putting an effectual check, through this powerful chief, to a large portion of the 
infamous traffic carried on in the Bight of Benin, and also for extending the legitimate commerce of Great Britain with this part of Africa, and at the same time adding to our knowledge of the country, did not hesitate in adopting the arrangement which Clapperton had made with Bello. Accordingly it was determined to send him out again to that chief, by the way of Benin, with suitable companions and presents, in order that a communication might be opened between Soccatoo and the sea-coast, and an attempt made to carry into effect the objects to which Bello was supposed to have given his hearty assent.

It had been arranged that, after a certain period agreed upon, Bello should send down his messengers to Whidah, on the coast, to meet Captain Clapperton and his companions. On their arrival, however, in the Bight of Benin, they could neither gain any intelligence of Bello's messengers, nor did any of the people there know any thing of such names as Funda or Raka, the places which were pointed out by Bello as lying on the sea-coast. The country of Houssa, however, was well known by name, and as the precise geographical position of Soccatoo had been ascertained, our enterprising travellers could have no difficulty in knowing what direction to take; but the spot from whence it would be most advisable to start was a point not so easily to be determined. They finally, however, selected Badagry, for reasons that will be briefly stated; and proceeding northerly, from one chief to another, the survivors met with some delay, but no serious impediments, in reaching the spot of their destination.

The conduct, however, of Bello, though at first kind, was afterwards changed to every thing the reverse, for reasons which will appear in the course of the journal. His desire for establishing an amicable intercourse was not even hinted at, nor one word respecting the physician, the consul, or the slavetrade; and, either through ignorance or design (the former, in all probability), Bello had totally misled Clapperton as to the position of the city or district of Funda; which, instead of being on the sea-coast, as stated by him, is now ascertained to be at least 150 miles from the nearest part of the coast; and the other city, Raka, still farther in the interior. Indeed, one would almost suspect that Clapperton, from not being sufficiently acquainted with the Fellata language, must have mistaken the meaning of Bello on his former visit, had not the letter in Arabic, which he brought home from the latter, addressed to the king of England, borne him out in his representation of the 
proposals made or assented to by this chieftain. In this letter he says, "We agreed with him upon this (the prohibition of the exportation of slaves), on account of the good which will result from it, both to you and to us; and that a vessel of yours is to come to the harbour of Raka, with two cannons, and the quantities of powder, shot, \&c. which they require, as also a number of muskets: we will then send our officer to arrange and settle every thing with your consul, and fix a certain period for the arrival of your merchant ships; and when they come, they may traffic and deal with our merchants. Then, after their return, the consul may reside in that harbour (namely, Raka) as protector, in company with our agent there, if God be pleased."

It is clear, from this letter, that Bello understood what was proposed and accepted, but, with regard to the geographical position of his two sea-ports, he was evidently most grossly ignorant; for, admitting the ambiguity of the Arabic word bahr, which signifies any great collection of water, whether sea, lake, or river, merchant ships could not get up to Raka, which is an inland town, not sitnated ou any coast or river. Be this as it niay, an expedition, as already stated, was planned without loss of time, at the head of which Clapperton was placed. He was allowed to take with him, as a companion, a fellow-countryman of the name of Dickson, who had been brought up as a surgeon, in which capacity he had served in the West Indies, but had recently been studying the law. This person considered himself to be inured to a tropical climate, and was supposed to have a sufficient knowledge of medicine to take care of himself and the rest of the party.

In an enterprise of this novel and hazardous nature, it was deemed advisable to unite two other gentlemen to those above-mentioned; in order that, when once at Soccatoo, two of them might be spared to set out from thence, and explore the country of Soudan in various directions. For this purpose, Captain Pearce of the navy, and Dr. Morrison, a naval surgeon, were selected; the former an active and accomplished officer, and a most excellent draughtsman; the latter well versed in various branches of natural history. Unhappily, it was not their good fortune to live long enough to put their respective talents in practice for the benefit of the public, or the gratification of their friends; having each of them, on the same day, fallen a sacrifice to the pestilential climate, at a very early period of their journey in Africa.

The presents intended for the Sultan of the Fellatas, and also for the 
Sheik of Bornou, being all ready, the four gentlemen, with their servants, embarked in his majesty's ship Brazen on the 27th August, 1825, and, after touching at Teneriffe and St. Jago, arrived in the Bight of Benin on the 26th November, 1825. Mr. Dickson being desirous of making his way alone to Soccatoo, for what reason it does not appear, was landed at Whidah, where a Portuguese gentleman, of the name of De Sousa, offered to accompany him as far as Dahomey, where he had resided for some time in the employ of the king. 'The offer was accepted, and Dickson, taking with him a mulatto of the name of Cohumbus, who had been a servant to Lientenant-Colonel Denham on the former expedition to Bornou, departed on the abth November, arrived safe at Dahomey, where he was well received, and sent forward to a place called Shar, seventeen days' from Dahomey, under a suitable escort, where he also arrived safely, and had an escort given him from thence on his intended journey to Youri, since which no account of him whatever has been received. By some Dahomey messengers, which Clapperton met with at Wawa, he sent a letter to Dickson; but it is evident they did not fall in with him, as the letter was some months afterwards sent down to the coast. It may here be observed, that though Whidah was the port to which Bello was ultimately understood to say he would despatch his messengers to convey the travellers, and their presents and baggage, to Soccatoo, it did not appear that any inquiries had been made there respecting them; nor did any person there seem to know more abont Bello or Soccatoo, than was known, further on, of Funda or Raka.

The rest of the travellers proceeded towards the river of Benin, where they encountered an English merchant of the name of Houtson, who advised them by no means to think of ascending that river, in their way into the interior, as the king of that country was well known to bear a particular hatred to the English, for their exertions in endeavouring to put a stop to the slave-trade, by which his greatest profits had been derived : nor had he any knowledge how far, or in what direction that river might convey them; he mentioned Badagry as a place far more preferable, as being equally near to Soccatoo, and the chief of which was favourable to the English ; said that he would, no doubt, afford them protection and assistance on their journey, as far as his country extended, which was to the frontier of the kingdom of Yourriba. As Mr. Houtson had resided on this part of the coast for many years, and was well acquainted with 
the customs of the people, Captain Clapperton cngaged him to accompany the party as far as the city of Eyeo or Katunga, the capital of Yourriba. Having, therefore, arranged matters with Captain Willis of the Brazen, as to sending after them the heavy baggage, and keeping up, for a certain time, a communication with them, they landed on the 29th November at Badagry; and, under the sanction of the king, commenced their long journey on the r/th December, the details of which will be found in the following Journal.

On his arrival at the encampment of Bello, at a short distance fiom Soccatoo, Clapperton had every reason to be satisfied with his reception. While at Kano, he had received a letter from that chief, congratulating him on his first arrival there, and inviting him to Soccatoo; and when he discovered, soon after his arrival at that city, that Clapperton had left at Kano the presents intended for the Sheik of Bornou, he again wrote to him, in a friendly manner, very civilly informing him of the impossibility of his allowing the warlike stores to be sent to one with whom he was in a state of hostility: he told him, also, that he had letters from a most respectable quarter, putting him on his guard against Christian spies. These circumstances secm, by the servant's account, to have preyed very much on Clapperton's mind; and that, when seized with dysentery and inflammation of the bowels, which, after thirty-six days' illness, carried him off, Bello's coohess and suspicion tended very much to depress his spirits and increase his disorder.

To Clapperton's Journal is appended that of his servant, Richard Lander, giving an account of his return journey from Kano, after his master's deatl, a great part of the way by a more casterly route. This journal of a very intelligent young man will be read with interest. Accompanied by two or three slaves, and a black man of Houssa, of the name (English) of Pascoe, who once belonged to a British ship of war, and had been engaged to attend Belzoni as interpreter, with a scanty supply of money, and without presents of any kind (so necessary in this country), he not only made his way among the various tribes he had to pass through, but brought with him, in safety, a large trink belonging to his master, containing his clothes and other property; three watches, which he secreted about his person, to preserve from the rapacity of Bello; and all his master's papers and journals, with which, after a journcy of nine months, he arrived in safety on the sea-coast.

The friendship and kind feching which Clapperton cntertained for this 
valuable servant is evinced in various letters written to him while he remained in Kano, with the presents intended for the Sheik of Bornou; but which were first decoyed to Soccatoo, and afterwards meanly seized by the Sultan Bello, on the pretext of their being, many of them, arms to be put into the hands of his enemy, he being then in a state of war with the sheik. In one of these letters he says, "I hope you ride out every day, and amuse yourself in shooting and stuffing birds, as this will tend to keep you in good health. Attend strictly to the duties of religion; rely firmly on the assistance and mercy of Heaven ; and, in all your difficulties and distress, this will bear you up like a man;" and he signs himself, " his sincere friend and master." In another letter, dated from Soceatoo, le says, "Pray to Heaven night and morning, and read the church service every Sunday; for a firm reliance on the justice and mercy, and assistance of Heaven, will bear you up with cheerfulness and courage, when all earthly friends and things fail. Farewell, and believe me your sincere friend and master."

Clapperton was, in fact, a kind-hearted and benevolent man, of a cheerful disposition, not easily put out of temper, and patient under disappointments; a virtue, indeed, which was frequently put to the test in the course of his long peregrinations in Africa. Both he and his servant suffered much from frequent attacks of fever and dysentery. His last illness continued for thirty-six days, during which he was attended by his faithful Richard; who has given a painful and interesting account of his death, of the mode in which he had him interred, of his own affliction, and the mournful state of solitude in which he was left among a set of unfeeling wretches, who regarded Christians in no better light than their dogs. His own situation is described in a letter which he addressed from Kano, after the death of his master, to Mr. Consul Warrington, of Tripoli. It is as follows :--

"Honoured Sir,

"Kano, 27th May, $182 \%$.

"With sorrow I have to acquaint you of the death of my master, Captain Clapperton. He departed this life at Soccatoo, on the 13th of April, at six o'clock in the morning, after thirty-six days' illness, with a severe inflammation in the inside, much regretted by me, as he had always behaved like a father to me since I left England. I buried him at Jungavie, a small village 
five miles east of Soccatoo, at three o'clock in the afternoon of the same day, according to the rites of the church of England. He was carried on one of his own camels, and followed by no one but myself, and five people who went with me to dig the grave.

"We arrived at this place (Kano) on the 20th of July, 1826, and were treated with the greatest respect, and the persons in power were well pleased with their presents, until master asked to go to Bornou : after this we were treated like spies. I was left in Kano to take care of the baggage, and my master proceeded to Soccatoo, with the presents to Bello. When master asked permission to go to Bornou, Bello despatched a messenger off to Kano, with orders to bring me, with all the things, instantly to Soccatoo. I left Kano on the 25th of November, and arrived at Soccatoo the 20th of December. On the 21st, the sultan demanded the Sheik of Bornou's letters. Master gave them to him. He desired master to open them. He said it was more than his head was worth, to open his king's letters. He said, 'Then I will.' He then told him that he had received letters, from several respectable persons, to say that we were spies. Master said he must see those letters; but he would not show them. He waved his hand for us to go. We went home, and in the afternoon of the same day, the king's head men came, and demanded the Sheik of Bornou's present and the spare arms. My master said, "There is no faith in you; yon are worse than highway robbers.' They said, 'Take care, or you will lose your head.' He said, 'If I do lose it, it is for the rights of my country.' They then took the presents and arms, and went off; and, soon after, the sultan sent to say we must go by the desert, or by the way we came; we must not go to Bornou.

"I left Soccatoo the 4th of May, and arrived at Kano the 21st of May. I am waiting here for two hundred and forty-five thousand cowries, for different articles purchased by the Sultan of Soccatoo. As soon as I receive these, which I expect in ten days, I proceed to the sea-side by the way we came, or else by a nearer way by thirty-five miles, ten days due south of Kulfu, called Funda, which I expect is the Bight of Benin, as the Quorra runs to it. This river is called by us the Niger. If the Sultan of Kulfi1 assures me of the road being safe, I will go, as it will be a great advantage to the English. I send the copy of the Journal from Katunga to this town 
by an Arab, whom I have told that, on delivering them safe, yon will give him thirty dollars. I remain, \&c. "Servant to the late Captain Clapperton.

"Mr. Consul-General Warrington."

With regard to the Journal of Clapperton, it may be neessary to observe, that it is written throughout in the most loose and careless mamer; all orthography and grammar equally disregarded, and many of the proper names quite impossible to be made out; full of tautology, so as to have the same thing repeated over and over again daily, and even on the same day. Much, therefore, has been left out, in sending it to the press, but nothing whatever is omitted, that could be considered of the least importanee; and the only ehange that has been made is that of breaking it into chapters, which is always a relief to the reader. Clapperton was evidently a man of no edueation; he nowhere disturbs the progress of the day's narrative by any refleetions of his own, but eontents himself with notieing objects as they appear before him, and conversations just as they were held; setting down both in his Journal without order, or any kind of arrangement. This may, perhaps, in one respeet be eonsidered as an advantage. The reader sees the naked faets as they oceurred, and is left free to draw his own inferenee from them. There is no theory, no speculation, searcely an opinion advaneed throughout the whole of his Journal. He has not contributed mueh to general seienee, but, by his frequent observations for the latitude and longitude of places, he has made a most valuable addition to the geography of Northern Afriea; and it may now be said of him, what will most probably never be said of any other person, that he has traversed the whole of that eountry, from the Mediterranean to the Bight of Benin.

The map that aecompanies the Journal was eonstructed entirely fiom the latitudes and longitudes in a table annexed to that document. That portion of it which shows the route pursued by Riehard Lander on his return, till stopped by the Fellatas at Dunrora, and from thence back again to Zegzeg, was laid off from the bearings and distanees marked down by this intelligent young man; and no better proof is wanting of its general accuracy than that of his return route elosing in with the fixed point Zaria, or Zegzeg, within ten miles. 
It is greatly to be regretted, that the premature deaths of Captain Pearce and Dr. Morrison have deprived the world of many beautiful specimens of art, and many valuable acquisitions to the stores of natural history. Among the vegetable products of the tropical regions of North Africa, which, from the general descriptions here and there given, are of great beauty and fertility, there are no doubt to be found many new and valuable species; the whole line from the Bight of Benin to Soccatoo being entirely untrodden ground, consisting of every variety of feature, mostly left in a state of nature, and a great portion of it covered with magnificent forests.

Various notices are given, in the Journal, of two objects of peculiar interest, which are still left open for further investigation; the course and termination of the river which has been (improperly, as it now appears) called the Niger, and the recovery of the papers, which still exist, of the late Mungo Park. The exact spot on which he perished, and the manner of his death, are now ascertained with precision. The former of these inquiries will now be considered, perhaps, to have lost much of its original interest, by the deflection which that river takes from its easterly into that of a southerly course; and which, in point of fact and strict propriety, has destroyed every pretension to its continuing the name of Niger. It camnot be supposed that either Herodotus, or Ptolemy, or Pliny, or any Greek or Roman writer whatever, could have had the slightest intimation of such a river as this, so far to the westward and to the southward of the Great Desert, of the crossing of which by any of the ancient travellers there does not exist the slightest testimony. The name of Quorra, or Cowarra, by which it is known universally in Soudan, and probably also to the westward of Timbuctoo, ought now, therefore, to be adopted on our charts of Africa.

With regard to its termination, the reports continue to be contradictory, and the question is still open to conjecture. Its direction, as far as has now been ascertained, points to the Bight of Benin ; but there is still a considerable distance, and a deep range of granite mountains intervening, between the point to which with any certainty it has been traced, and the sea-coast. If, however, it be the fact, that the river of Benin has been traced as high up as is marked on the chart (and it is taken from an old chart of the year 1753, stated to have been engraved for Postlethwayte's Dictionary), that distance, between the lowest ascertained point of the Quorra and the highest of the Benin, is 
reduced to little more than a degree of latitude, or about seventy miles; but it is seventy miles of a mountainous country. By our occupation of the beautiful and fertile island of Fernando Po, and the extension of African commerce which may be anticipated in consequence thereof, there can be little doubt that this question of their identity or otherwise will ere long be decided.

From a variety of notices obtained by Clapperton, it is pretty clear, that the particulars of the death of Mungo Park, and the spot where the fatal event happened, are not very different from what was originally reported by Amadoo Fatima, and has since been repeated in various parts of the continent. The following correspondence, which was found in one of Clapperton's memorandum books, and translated from the Arabic by Mr. Abraham Salamé, is highly interesting; and the more important, from the avowal of an individual, that he is in possession of the books of that enterprising traveller, and is ready to deliver them up to any person duly authorised by the sovereign of England to receive them.

TRANSLATION OF SOME DOCUMENTS RELATIVE IO MUNGO PARI'S DEATH

AND PAPERS.

No. 1 .

"Praise is due to God alone!-As to the subject of the Christians who were drowned in the river of Boossy, they consisted of two freemen, and two slaves, their own property. The event thus happened in the month of Rajab: As their ship or vessel was proceeding down the river, it came to a narrow place or creek, into which they pusher it, and remained there three days; but the people of Boossy, having observed them, assembled, and went and fought them for three days. When the fight became severe, they (the Christians) began to take up their goods, and throw them into the river, till they had thrown a great quantity; and on the fight becoming still more severe (desperate), one of them got out, and threw himself into the river, and died; and, in the same manner, the other followed him, leaving their two slaves imprisoned in the ship; so that the hands of the people of Boossy did not reach so far as to kill them (i.e. they died in drowning, and were not murdered). Thus I have heard, and do herein write it myself.

$$
\text { "The Sharif of Bokharr." }
$$


No. 2.

Arabic Letter from Clapperton to the Lord of Boossy.

Translation._- Praise be to God, and prayers and peace be unto his apostle. From Abdallah, the English ràis (captain), to the lord of Boossy, named Moosa (Moses), with regard and salutation; and that he has heard that the writings of his brethren, who were slain by the people of your country, have come into your hands. He therefore wishes you to give them up to him, either by purchase, or as a gift, or by exchange for a book of your own (the Koràn), or, at least, to let him see them only. We conjure thee, $\mathrm{O}$ lord, by God, by God, by God! and Sàlàm to you."

The reply to this does not appear among Clapperton's papers; but, from the following letter, it may be concluded that he was referred to the Lord of Yàoury.-A. S.

No. 3.

Arabic Letter from Clapperton to the Lord of Yàoury.

Translation.- " Praise be to God alone. From Abdallah, the English captain, to the Lord of Yàoury. Hence respecting the book of the Christians who were seized by the people of Boossy, he wishes you to give it to him, that he may deliver it to his master, the Great Lord of the English nation. This only is his desire; and Sàlàm be to you."

No. 4 .

Reply to the above.

Translation._- "This is issued from the Prince or Lord of Yàoury to Abdallah, the English captain: salutation and esteem. Hence your messenger has arrived and brought us your letter, and we understand what you write. You inquire about a thing that has no trace with us. The Prince or Lord of Boossy is older (or greater) than us, because he is our grandfather. Why did not you inquire of him about what you wish for? You were at Boossy, and did not inquire of the inhabitants what was the cause of the destruction of the ship and your friends, nor what happened between them of evil; but you do now inquire of one who is far off, and knows nothing of the cause of their (the Christians') destruction. 
"As to the book which is in our hand, it is true, and we did not give it to your messenger; but we will deliver it to you, if you come and show us a letter from your lord. You shall then see it and have it, if God be pleased. And much esteem and Salàm be to you, and prayer and peace unto the last of the apostles."-(Mohammed.)

\section{No. 5.}

The following is a letter from Clapperton to some prince or grandee, whose name is blotted out of the copy book, complaining of the above refusal of the Lord of Yàoury.

Translation. - " Hence, my lord, I have written to the Lord of Boossy about the Christian book, whose owner was destroyed by the inhabitants; but when I heard that it was in the hands of the Lord of Yàoury, I wrote to him to give it to me, and he has refused. I have therefore written to you."

It cannot be doubted for a moment, that volunteers enough will be found ready to proceed on an enterprise of so much interest; and for an object, the recovery of which is not only due to the reputation of the lamented traveller, but to the nation to which he belonged, and to the government under whose auspices he undertook to make discoveries in Africa. If Clapperton's servant could find his way, alone and unprotected, through three times the distance it would be necessary to travel for the object in question, how much more likely would a duly accredited agent, bearing some trifling presents, and a letter from the King of England, be certain of making good his way, without difficulty, in the same track which has so recently been trodden, without molestation, by Christians and white men. A few presents, and but a few, and of trifling value, would only be necessary to secure the protection and assistance of the native chieftains on the road.

It is much to be regretted that Clapperton himself did not personally wait upon the Sultan of Yaoury, whose residence is not more than twenty-five or thirty miles northward of Boossy, and who appears to have been most anxious to see the Christian traveller, and pay him every possible attention. He sent messengers with presents, and boats to convey him up the river to Yaoury. Clapperton, however, had, no doubt, sufficient reasons for not visiting that chieftain at this time: it might be on account of the delay it would occasion at a time he was most anxious to get to Kano, to avoid the rains; or, 
for the sake of keeping clear of the belligerent parties who were ravaging the country in that direction. Perhaps he thought that, not being furnished witl a letter to the sultan of that country, he would not have given up the papers to him. And, after all, it is not quite certain, from what he afterwards learned, that the Sultan of Yaoury has in his possession any thing more than some printed books; for on Clapperton inquiring of one of the sultan's people, if there were any books like his own Journal, the man said there was one, but that his master had given it to an Arab merchant ten years ago; but that the merchant was killed by the Fellatas on his way to Kano, and what had become of that book afterwards he did not know.

The death of Dr. Morrison, at an early period of the journey, deprived the scientific world of all information on the subject of natural history, of which, as might well be supposed, neither Clapperton nor his servant had any knowledge. It will be matter of regret to some, that they had not, which they might easily have done, collected specimens of the language of the several districts through which they passed. The little that is added to the Appendix is all that was found among the papers of the decensed commander on this subject; and the state of the thermometer and barometer at different hours of the day, as observed on the journey, and also by Lander at Kano and Soccatoo, is not quite complete.

J. B. 



\section{O N T E N T S.}

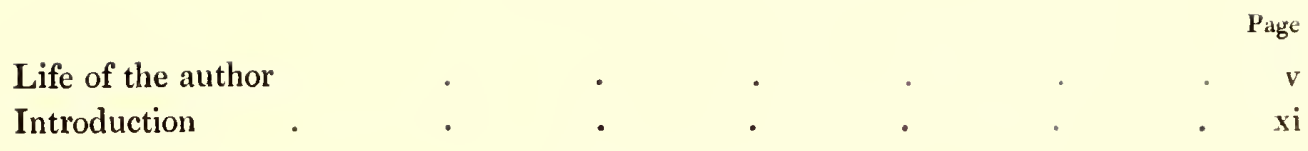

CHAPTER I.

Journey from Badagry over the Kong mountains to the city of Eyeo or Katunga 1

CHAPTER II.

Residence at Eyeo, or Katunga, the capital of Youriba $\quad$ • $\quad 38$

\section{CHAPTER III.}

Journal of proceedings from Katunga, or Eyeo, to Boussa, on the Niger, or Quorra, the place where Mungo Park perished

\section{CHAPTER IV.}

Journey from Boussa, across the ferry of the Quorra, by Guarri and Zegzeg, to the city of Kano

\section{CHAP'ER V.}

Journey from Kano to the camp of Bello, and from thence to Soccatoo

\section{CHAPTER VI.}

Residence at Soccatoo, till the death of the author

\section{LANDER'S JOURNAL.}

From Kano to Soccatoo

Residence at Soccatoo-my master's death-burial 
E X P E D I T I O N

FOR

THE DISCOVERY OF THE INTERIOR

OF

NOR THER N F I C A. 


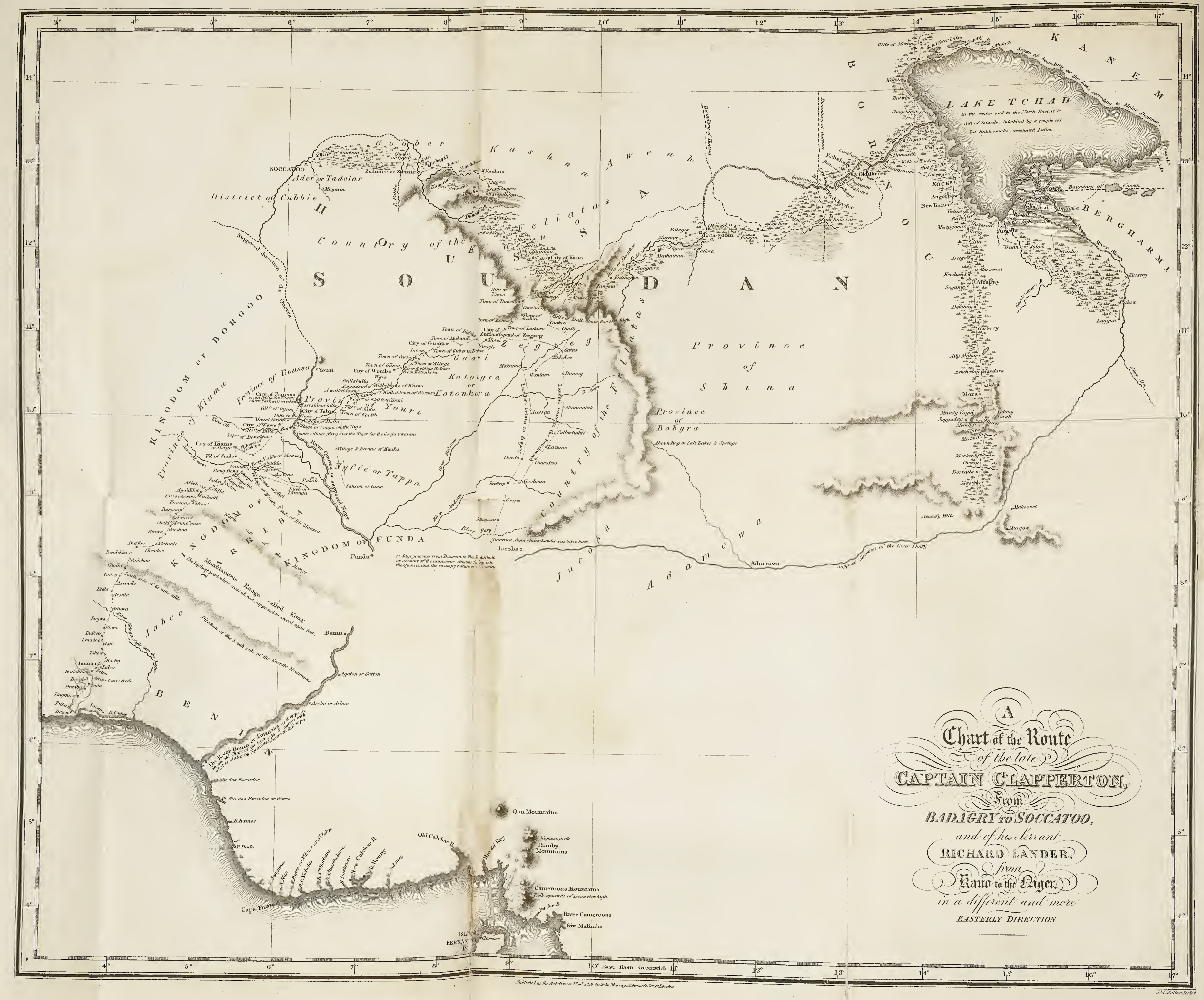





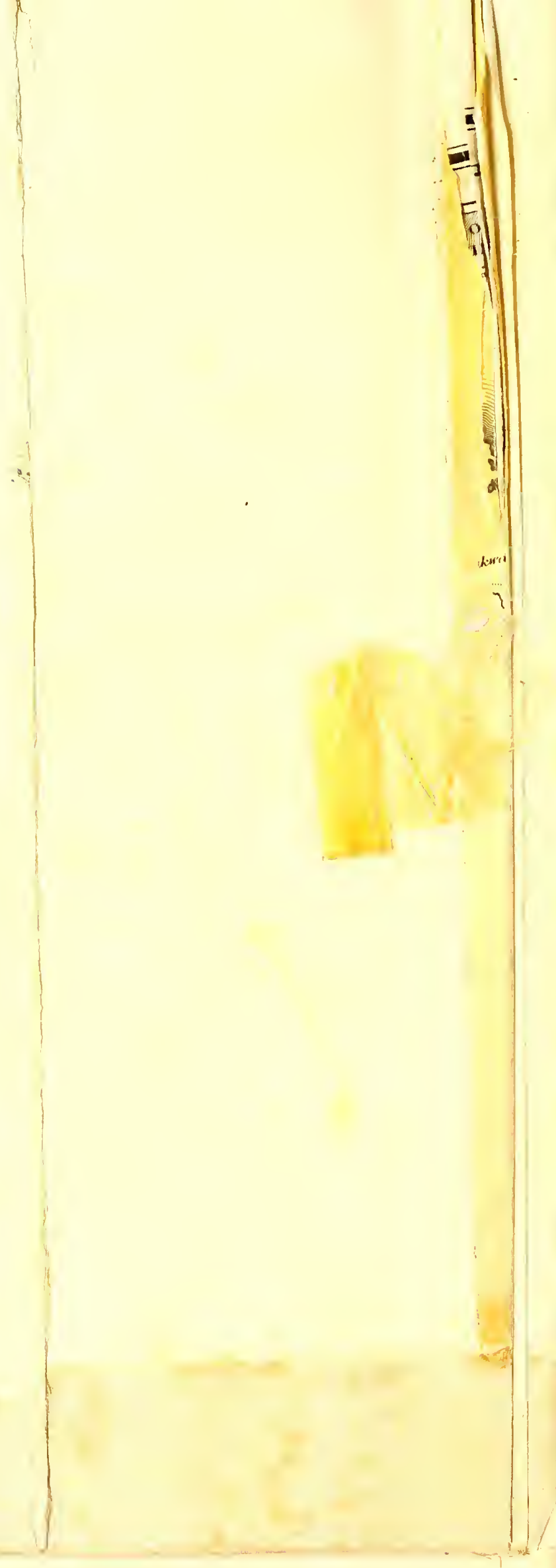




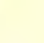




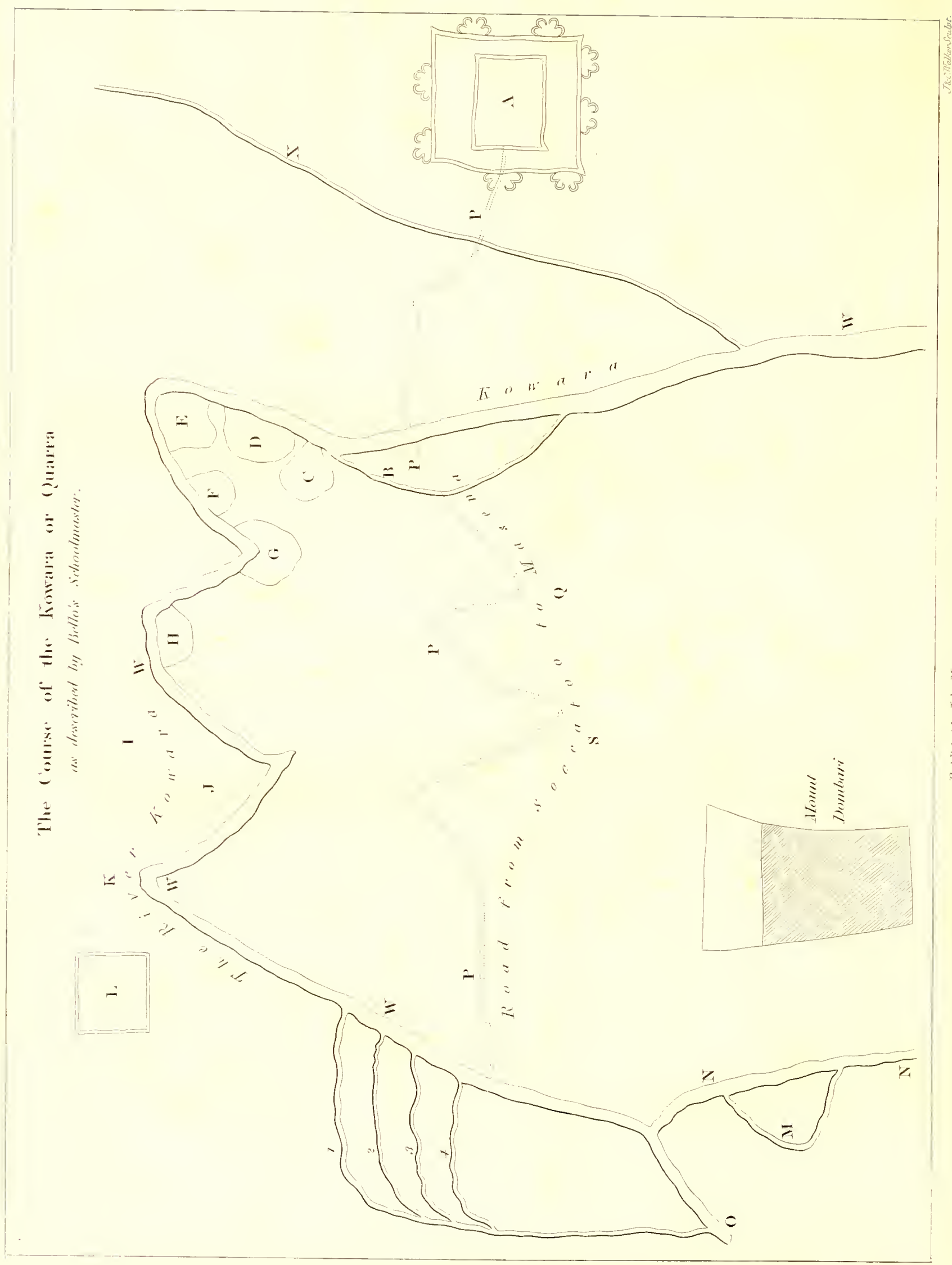




\section{EXIEDITION}

For

THE DISCOVERY OF THE INTERIOR

OF

\section{NORTHERN AFRICA.}

\section{CHAPTER I. \\ JOURNEY FROM BADAGRY OVER TII KONG MOUNTAYNS TO THE CITY OF EYEO OR KATUNGA.}

Wednesday, December 7th, 1825.-After a great deal of palavering and drinking with our African friends, we succeeded in getting off all our baggage and presents; and embarked in the canoes provided for our accommodation. That in which I was with the presents and stores, being very heavy, proceeded slowly up a branch of the Lagos river as far as the junction of the Gazie creek, up which we then proceeded about a mile and a half, and landed on the west bank. The banks of both these small rivers are low, and covered with reeds : at the place where we halted, a market is held for the Badagry people, and those of Puka and other neighbouring towns; it is called Bawie. The Gazie comes from the north-west, ruming through part of the kingdom of Dahomy, having its rise in the country called Keeto.

Thursday, 8th.-Morning thick and hazy, and though sleeping close to the river in the open air, for the first time since we have been on shore, we did not hear the hum of a single musquito. 'The 
canoes of our attendants were armed with sinall guns in the bow, to guard us from the danger of any attack; Adoli had his cook and one of his wives with him in his own canoe, the after part of which was covered with a matted roof.

While halting here Mr. Houtson and I walked on to the town of Puka, leaving the baggage and stores to come on after us. The path over which we travelled was partly cleared, and covered with high grass wherever it was clear of wood; and had apparently once been cultivated. 'The woods were thick and the trees high, with a great deal of tangle and underwood, so as to render it impenetrable to man or beast excepting along the path. 'The country is low and flat, and the soil a red clay mixed with sand.

On arriving at Puka, we halted under a tree, and were surrounded by immense crowds of people, who were very civil : those who could not get near enough to see us, on account of their small size, were held up on other's' shouklers; and from the great number of old people and of young children, it would appear that they are not much in the habit of selling their children at this place. They are all negro pagans. Tre had a visit from one of the Eyeo war chiefs, who came in state: he was mounted on a small horse, as were also two of his attendants; the saddles and ornaments were the same as those in Soudan and Bornou; the rest of the cavalcade were on foot, amongst which was a little boy apparently the favourite slave of the chief, judging from the conspicuous part he bore, and the great attention which was paid to him by all the others. His dress and appearance was most grotesque, consisting of a ragged red coat with yellow facings, a military cap and feather apparently Portuguese. 'The captain came curvetting and leaping his horse until within the distance of a hundred yards, when he dismounted, and approached within twenty yards of us, where he sat down. We then sent our umbrella as a message or token that we wished him well; and on the receipt of which, the drums beat 
and hands were clapped, and fingers cracked at a great rate. He now came up to us, capering and dancing the whole way, and shook us by the hand, a few of his attendants accompanying him. He then began his speech, saying he was very glad that he now saw white man; and pointing to the various parts of his dress, he said, This cloth is not made in my country, this cap is of white man's velvet, these trowsers are of white man's nankeen, this is a white man's shawl; we get all good things from white man, and we must therefore be glad when white man come to visit our country. The two men who appeared next in authority to himself were stout good-looking men, natives of Bornou; they were dressed in the fashion of that country, with blue velvet caps on their heads. Being Mahometans, they could not be prevailed on to drink spirits, but the captain and his men drank each two drams.

We paid a visit to the caboceer, or chief man of the town. We found him seated in the midst of his elders and women. He was an ancient, tall, stupid-looking man, dressed in a red silken tobe, or long shirt; on his head was a cap made of small glass beads of various colours, surrounded by tassels of small gold-coloured beads, and three large coral ones in front. The cap was the best part of the man, for it was very neat; in his hand he held a flyflapper, the handle of which was covered with beads. After a number of compliments, we were presented with goroo-nuts and water. We told him of our intention to proceed to Eyeo, that we were servants of the king of England, and that we wanted carriers for ourselves and baggage. We remained here for the night, and as all our baggage had not come up from the coast, Captain Pearce went down to the beach after them.

As soon as we hat removed into the caboceer's house he sent us a present of a sheep, a basket of yams, and some fire-wood. His wives and young women came peeping at us through the holes 
in the walls, and at the doors; and whenever we went near them they would run off. Captain Adamooli told us to keep a good look out after our things, for the people here were great thieves. I said he must make his men keep watch, as I held him answerable for whatever might be lost. Accordingly he sent the greater part of his troop, he himself taking up his station at the principal door, where they kept drumming all night.

This morning, Friday, 9, there was a good deal of palavering between the captain and the old caboceer, while we sat patiently waiting the removal of the baggage and stores from his house. I found the old caboceer sitting on a chair with an umbrella held orer his head; his aged counsellors by his side. The old gentleman was carefully counting all the articles as they were brought out, laying a small piece of stick on each ; they were then counted over a second and a third time, after which the bundles were tied up; not however before they obliged me to count them over, and till I said all was right. After waiting about two hours for carriers, the old caboceer said with the most invincible gravity that he would not procure a single carrier, alleging that he had not received enough for a present. We then declared we would return to Badagry, and let the king know of his conduct, and made a show of going that way; but the old caboceer was not in the least moved. Poor Captain Adamooli, however, prostrated himself before me, laid hold of my legs, and said he should lose his head if $I$ went back. I therefore returned, and he loaded his own people; the old wretch not giving us a single man.

Having seen the whole of the baggage off, we started in the evening, and proceeded on our journey. We learned in fact that we were not now in the king of Badagry's territory, but in a district of Eyeo, which is called Yarriba by the Arabs and people of Houssa, and that the name of the capital is called Katunga, and that it is thirty days' journey. Finding we could get no men to carry the 
hammocks which they supplied us with, I mounted my friend Ali's small horse, without a saddle, and Houtson and I agreed to ride and tie, as my feet were cut and blistered with a pair of new boots I had mounted yesterday, and I could only wear a pair of slippers. We set off in this state, accompanied by the caboceer of Jannah's messenger, named Acra, and Mr. Houtson's boys. Puka, which we are leaving, has once been a large town, surrounded by a wall and deep ditch; the wall is now down, and all the houses of the town in ruins. After leaving this place it soon became dark, and we frequently lost our way. We could see, however, that the road in the open part of the country was through fine plantations of corn; the rest was through thick dark woods, where we could not see the heaven over our heads, the path winding in every direction. My slippers being down at the heels I soon lost them off my feet, which were miserably cut; but I became so galled by riding without a saddle, that I was compelled thus to walk barefooted, which was the worst of the two; for whenever I crossed an ant path, which were frequent, my feet felt as if in the fire, these little animals drawing blood from them and from my ankles. We halted at a village called Isako, after passing several others on the road: here the people offered us a house for the night, but on their telling us that our people had gone on to a town a short distance off, we remained only a little while and set off again. They kindly gave us guides with lamps to show us the way. Our short rest and ride had had a bad effect on us, and the road only wanted thorns to make our misery complete. However, after struggling on till midnight, we arrived at a town called Dagmoo, where we found our servants with the heavy baggage and the canteen, but our beds had gone further on, so that we were obliged to sleep in the marketplace, in the open air: even this, with a little cold meat, was bettei than travelling.

Saturday, 10th.- The morning raw, cold, and hazy, and we had 
nothing to eat. The road lay through the thickest woods I ever saw ; and, except on the narrow footpath, wholly impenetrable by man or beast: the surface rather uneven; the soil a strong red clay. We passed several people, principally women, heavily laden with cloth, plantains, and a paste made from pounded Indian corn, wrapped in leaves called accasson, going to market. 'They were all extremely civil, and never omitted saluting us, or giving us the road. One woman, whom I made signs to that I was thirsty, was nearly crying that she had no water to give, but would make us take plantains and accassons. Shortly after leaving Dagmoo we crossed a small stream, over which I was carried. About noon, arrived at the town of Humba, where I found Captain Pearce and Dr. Morrison in the caboceer's house, and the caboceer waiting in state to receive 13. Here I had my feet bathed, but found I had a considerable degree of fever on me, and was glad to get to bed. In the afternoon I had a slight fit of ague. The house was in a very ruinous state; and, indeed, the whole town, as far as we saw of it, was equally so. The inhabitants, however, were cheerful enough, and kept singing and dancing all night round our house; their songs were in chorus, and not unlike some church music that I have heard.

Sunday, 11th.- Though very weak, I walked on for a mile to a town called Akalou, where the baggage was halted; and here I found a black captain in a leopard skin cloak, holding a palaver, and declaring he would neither go nor let the baggage go on, without a flask of rum. Mr. Houtson gave him a glass of grog, when, after keeping it in his mouth for some time, he poured it out of his own into the mouths of his attendants. After this the baggage proceeded, and I had two men to carry me in my hammock; but they had not gone twenty paces before they set me down, and said they would carry me no further. I accordingly endeavoured to creep on slowly, but on seeing the fellows walking very deliberately 
after me, I took my gun and presented it at them, when they threw down the empty hammock and fled. The two messengers, however, took me up and carried me to a town called Eto, where we were to change the bearers. The caboceer of this place sent us a goat and a basket of yams, and Mr. Houtson gave him in return a flask of rum. Here I procured hammock-men, and we left Eto and proceeded on through thick woods to Sado or Isado, where we halted in the palaver house. Here, as in other places since leaving Puka, our articles of baggage were strictly counted in presence of the caboceer. The people sung and danced all night around our houses.

The soil between this place and Humba is generally a strong red clay, and there must be considerable plantations not far from the road, but none appear near the towns for the support of the numerous inhabitants. I judge we are not far from the banks of the river which they say we are to cross to-morrow; but old Acra, the messenger, says, that the fetish at Gazie would kill any white man that came up the river, and that this is the only reason why we did not come that way.

Monday, 12th.- Morning raw and hazy; our things going off with alacrity this morning, and hammock-men provided. Leaving Sado, the road lay principally through thick woods for an hour, when we arrived at the town of Bidgie, where there are some fine plantations of corn and plantains. 'The caboceer was all ready to receive us: a fine civil young fellow, his name Lorokekri. They came in crowds to see us; and on our expressing a wish to proceed on without delay, he begged we would stop all day, as neither he nor his people had ever seen white men before, and he was desirous of giving us something to eat. Mr. Houtson and I went down to the river, embarked in a canoe, and crossed over to the other side. We found there was no place clear of wood except the footpath. 'The river we had to cross was about a quarter of 
a mile in width, full of low swampy islands and floating reeds. 'The natives appear to have a number of canoes, which are not used with paddles, but a forked pole, and they manage them very cleverly.

At this place Dr. Morrison was taken very unwell, and had slight symptoins of fever. The caboceer made us a present of two hogs and some yams. We observed here some women very oddly marked, having small raised dots, like wens, across the forehead, about half an inch apart; those on the cheek about an inch. 'They are made by cutting and lifting the skin.

'Tuesday, 13th._This morning Dr. Morrison was better, and we left Bidgie in the canoes. The road from this place was through a dry swamp nearly the whole way. The sun was very oppressive, and I had sent my umbrella on. About midday I sat down in the shade, quite exhausted by the heat, when a horseman came up; he kindly dismounted, and gave me his horse, while he walked with me to the village of Atalioboloo, where the baggage and people were halted, waiting for carriers to come from the next town. I procured rooms in the principal man's house for Captain Pearce and Dr. Morrison, who were indisposed. This town is surrounded with plantations of yams and com; numbers of people were on the road going to the market at Bidgie. The carriers having arrived from Laboo, the sick, and the greater part of the baggage, sent forward, Houtson and I followed in hammocks; the road lying through fine plantations of yams, and nearly as level as a bowling-green. In the evening I was met by the Jannah messenger, with an offecr of the caboceer of Laboo, bringing horses for the party : we got out of our hammocks and mounted. I was the only one that had a saddle, but it was so hard and the stirrups so short, that it became a question which of us had the best bargain. We soon arrived at the town of Laboo, wich stands on an eminence, and is the cleanest we have seen since we first set foot in Africa. The country has now become beautiful, rising into hill and dale, from which there are some fine views: part 
of our road lay through large plantations of corn and yams and fine avenues of trees.

At 7 P. M. we arrived at Laboo. The approach to the town appeared by the moonlight quite enchanting, being through an avenue of tall majestic trees, with fetish houses placed here and there, and solitary lights burning by each. On entering the town we were taken to the caboceer's house, where he was sitting under his verandah ready to receive us, and the house was crowded with spectators; he rose as high as the roof would admit, welcomed us to his country, and said he was glad to see us. We told him there was one sick gentleman behind, and requested he would send lights, and people to assist to bring him up. In less than two hours Dr. Morrison arrived; and having received a present of a pig and five baskets of yams, we prepared our supper and went to bed.

Wednesday, 14th.- The morning raw and cold; Morrison a little better; Captain Pearce and my servant Richard Lander taken ill. After daylight the caboceer sent to inquire after our health, and at $10 \mathrm{~A}$. M. we paid him a visit. We found him in the same place we saw him last night. The whole of the verandah and square was full of people, except a small space for those who came to prostrate themselves. In the centre of the square was a large baboon and pole, and a forked stick, with water for pigeons, that were continually flying about our heads. Behind the caboceer sat about two hundred of his wives and concubines. He was sitting on a mat, reclining on a large round pillow, one of each of which he immediately ordered for us. We sat down beside hin and gave him a glass of grog, which he drank off with great relish, turning himself round so that his own people might not see him drink. We handed a few glasses more to his ladies, and a goblet full to his headmen, who were sitting in front with all the marks of their morning's salutation of their master. Their obeisance is a conplete prostration of the body at full length on the ground, with 
the chin resting on the hands, turning one cheek to the ground, then the other, and finally to bestow a kiss on their mother earth and rise. Before entering the caboceer's presence their heads must be covered with dust or clay. He told us he had a house at Eyeo, and that half his wives were there. When he spoke in a complimentary way to us, all the people clapped their hands joyfully. When we told him that a white man had only one wife, he and the whole people, with his wives, laughed immoderately. After staying with him an hour we took our leave, giving him two bottles of rum, and a promise of something more when the baggage airived. The town of Laboo is large, and stands on a rising ground on the top of a small hill, and in some parts commands an extensive view, particularly to the south, which is low and Hat. Lagos, we were told, can be reached in one day by a messenger.

Thursday, 15th.-Our sick better: at eight, sent them off in the hammocks: at nine, started on horseback, but waited a short time for the caboceer, who came mounted, but without stirrups. He attended us some distance out of town with the whole population of Laboo around him, the women singing in chorus and holding up both hands as we passed; and groups of people were kneeling down and apparently wishing us a good journey. 'The country well cultivated and beautiful, rising into hill and dale : from the tops of the hills we had distant views, the road leading through plantations of millet, yams, alavances, and Indian corn.

On arriving at Jannah about noon, I found our poor sick halted in the palaver house, which is an open shed, surrounded by thousands of people making a great noise. Here we had to wait about an hour before the caboceer made his appearance, which however at last he did, gorgeously arrayed in a large yellow silken shirt and red velvet cap; with a silver mounted and silver wrought kind of horewhip ornamented with beads, in one hand, and a child's silver bells in the other, which he rattled or shook when he spoke: he 
was seated on a large leathern cushion, which was placed on a mat covered with scarlet cloth. On the cloth I was going to sit down, but the ladies very unceremoniously whipt it from under me, and I squatted myself on the mat; his female attendants sung in chorus very beautifully: the drummers were at a more respectable distance, and the whole space in front of his house was covered with people. Here also were the worshippers, who paid their respects in due form to their master, going out and coming in three times. We shook hands with him. He said he was glad to see us; that whatever we had to say to the king of Eyeo we must first deliver to him ; that if he approved of our palaver, so would the king; but if not, neither would the king of Eyeo. This seemed somewhat ungracious and conseguential, especially when coupled with his apparent inattention while the interpreter was speaking to him : but on our explaining to him that we had nothing of particular importance to say to the king of Eyeo beyond a request that he would accept the king of England's respects, and grant a passage throngh his country, he said all was right; that he was glad we should see the king of Eyeo's face; that God would give us a good path, and that he would forward us right on without any trouble. We then asked him for a house : he said he would give us into the hands of his principal servant, who would lend us his house, to which we went. We found it pretty well occupied with people, but there was a room each for the sick, and Houtson and I took up our quarters in the verandah. In the evening we were visited by the caboceer incognito. He was now quite a different man: his servant Akoni, who had come with ns from Badagry, sat down, and the caboceer made a seat of his knee. He now conversed freely, gave us a great deal of good advice, and spoke of God more like a christian than a pagan. He said that the king of Eyeo would not allow us to go through his dominions, but that he would give us horses and carriers to bring us to the king; but that the Eyeo people were unaccustomed to carry hammocks, and we must go on horscback. He repeatedly assured us of safe 
conduct to Eyeo, and said we might start to-morrow if our sick were well. We then gave him the greatest part of our string of coral, which in this country is highly esteemed. Mr. Houtson learnt this evening that a message had arrived to the caboceer from some part of the coast, probably Lagos or Dahomy, advising him that the Englishmen were going to make war upon the king of Eyeo, and that we might perhaps kill the king: this, I apprehend, was the reason why he was so positive in wanting to know our business with the king of Eyeo.

Friday, 16th.-Morning raw and hazy. We this morning received two goats, a hog, and a large quantity of yams, ten fowls and two pigeons. We are visited by a great number of the town'speople; and whenever we show ourselves out of the house we are followed by an immense crowd. We received a present of a goat and a quantity of yams from the town's-people. In the evening Mr. Houtson and I took a walk through the town: we were followed by an immense crowd, which gathered as we went along, but all very civil; the men taking off their caps, the women kneeling on their knees and one elbow, the other elbow resting upon the hand. In returning we came through the market, which, though nearly sunset, was well supplied with raw cotton, country cloths, provision, and fruit, such as oranges, limes, plantains, bananas; and vegetables, such as small onions, chalotes, pepper, and gums for soups; also, boiled yams and accassons. Here the crowd rolled on like a sea, the men jumping over the provision baskets, the boys dancing under the stalls, the women bawling, and saluting those who were looking after their scattered goods, yet no word or look of disrespect to us.

Saturday, 17th.-Morning clear. Captain Pearce much better; Richard worse. Dr. Morrison bled Richard in the temple in the evening, but he has had no relief.

Sunday, 18th.-Our patients to-day a little better. The town of Jannah stands on the side of a gentle hill, commanding an extensive 
view to the west; the view to the east is interrupted by thick woods. The inhabitants are apparently civil and industrious, and may amount from 8000 to 10,000 . 'They are great carvers; their doors, drums, and every thing of wood is carved. It has formerly been surrounded by a wall and ditch : the gate and ditch are now all that remain. The streets are irregular and narrow; the houses occupying a large space, and in the same form as those of Puka. Here, amongst the Yarribanies, is the poor dog treated with respect, and made the companion of man; here he has collars around his neck of different colours, and ornamented with cowries, and sits by his master, and follows him in all his journeys and visits. The great man is never witlout one, and it appeared to me a boy was appointed to take care of him. In no other country of Africa, that I have been in, is this faithful animal treated with common humanity.

Owing to a Brazilian brig having arrived at Badagry for slaves, the people here have been preparing themselves for two days to go on a slaving expedition to a place called Tabbo, lying to the eastward.

I cannot omit bearing testimony to the singular and perhaps unprecedented fact, that we have already travelled sixty miles in eight days, with a numerous and heavy baggage, and about ten different relays of carriers, without losing so much as the value of a shilling public or private; a circumstance evincing not only somewhat more than common honesty in the inhabitants, but a degree of subordination and regular government which could not have been supposed to exist amongst a people hitherto considered barbarians. Humanity, however, is the same in every land; government may restrain the vicious principles of our nature, but it is beyond the power even of African despotism to silence a woman's tongue: in sickness and in health, and at every stage, we have been obliged to endure their eternal loquacity and noise. 
We have observed several looms going here: in one house we saw eight or ten-in fact a regular manufactory. Their cloth is good in texture, and some very fine. 'They also manufacture earthenware, but prefer Luropean, though they sometimes misappropriate the different articles. The vessel in which the caboceer of Laboo presented us water to drink, Mr. Houtson recognised as a handsome chamber-pot sold by him last year at Badagry.

Monday, 19th._Captain Pearce is better this morning, but Richard continues still very ill with severe head-ache and fever.

Abont twelve o'clock we visited the caboceer at his own house. He had previously sent us about twenty-five gallons of rum, saying he heard we had not brought much rum with us ; that Eyeo people liked rum too much, and that he sent us this that we might give all his people a dram to get us a good name amongst the inhabitants.

We found his highness seated in the door-way of a room, in the inner verandah, and on his large leather cushion; behind were his singing women; and under the verandahs, on both sides of the doors, were his musicians and his headmen. He wore this morning a rich crimson damask robe, or shirt, and the same red velvet cap; but during the visit, to display his grandeur, he changed his dress three different times, each time wearing a richer than before. The whole court, which was large, was filled, crowded, crammed, with people, except a space in front where we sat, into which his highuess led Mr. Houtson and myself, one in each hand, and there we performed an African dance, to the great delight of the surrounding multitude. The tout ensemble would doubtless have formed an excellent subject for a caricaturist, and we regretied the absence of Captain Pearce to sketch off the old black caboceer, sailing majestically around in his damask robe, with a train-bearer behind him, and every now and then turning up his 
old withered face to myself, then to Mr. Houtson-then whisking round on one foot, then marching slow, with solemn gait, twining our hands in his-proud that a white man should dance with him. We gave in to the humours of the day, and thus "cheered we our old friend, and he was cheered." We sent for Captain Pearce, who came on his hammock, but he could only stay a few minutes, the noise being too great for him. In the evening we despatched our messenger to the caboceer to ask when the horses would be ready; he returned with an answer, that his highness was drunk to-night, but would see us to-morrow morning. Richard much worse : Dr. Morrison put a large blister over his head, which caused a temporary delirium; but as the blister rose he got better, and promises in the morning to be convalescent.

'T'uesday, 20th.-Morning raw and hazy. The caboceer called to inquire after the sick, and expressed much concern at their not getting well. Indeed Dr. Morrison continued very weak, and Captain Pearce getting weaker; Richard something better.

Wednesday, 21st.-The caboceer came this morning with his headmen to overhaul the packages, to see how many carriers would be requisite. We tried for hammock-men for the sick, but the caboceer said, that the Eyeo people could not and would not carry a hammock - that a man was not a horse; which, to be sure, was a truism so obvious and ancient, that we could not venture to contradict it. I offered him a string of coral, which to him is most tempting, but he would not make a positive promise. However, he sent a messenger in the evening, saying that he would find hammocks to the first stage. He promised also to forward any thing that was sent from Badagry for the mission, and any thing from the mission to Badagry. We visited several manufactories of cloth and three dyehouses, with upwards of twenty vats or large earthen pots in each, and all in full work. The indigo here is of an excellent quality, and forms a most beautiful and durable dye; 
the women are the dyers, the boys the weavers; the loom and shuttles are on the same principle as the common English loom, but the warp only about four inches wide. Mr. Houtson was anxious to purchase the freedom of a Bornonese slave, a dwarf three feet high and thirty years of age, a cumning-looking rogue; but he was not willing to be sold, and his master would not therefore sell him.

Thursday, 29d.- This morning Dr. Morrison was looking ill, but in better spirits; Captain Pearce very weak; Richard better. In the extreme weak state of the two former, I thought it advisable to say to both, that I would either make arrangements for their remaining here until they were completely convalescent, or for their return on board the Brazen, provided hammocks could be got to carry them to Puka, and to go under the care of Mr. Houtson's boy, Accra; or, if necessary, that Mr. Houtson should himself take charge of them, and return them safe to Badagry. Captain Pearce expressed a decided determination to proceed, and Dr. Morrison would not even hear Mr. Houtson speak on the subject of a return or stay, but said he would proceed on. The caboceer came early, and after much trouble, and seemingly much difficulty, got men to carry the sick, his own son being obliged to take one end of a hammock. I observed that, on the caboceer's sneezing, all his attendants clapped their hands and snapped their fingers, a custom common to Benin, Lagos, and Dahomy, and similar to our exclamation of "God bless us" on the same occasion. The hammocks started early, when Mr. Houtson's small boys, owing to some people frightening them with stories of war on the path, and probably a message from their friends at Badagry requesting them to go no further, all ran away. He immediately despatched a letter for another interpreter, who will join us in a few days. About an hour afterwards, I started after the sick, leaving Mr. Houtson to see the baggage off.

Friday, 23d.-At 7 A. M. the sick left Bachy. Dr. Morrison 
looking very ill; Captain Pearce much the same; Richard better. We had presents, as usual, of yams, plantains, eggs, and a goat. At ten, arrived at Tshow; the country finely cleared, and diversified with hill and dale, a number of inhabitants travelling with us. A little after our arrival Dr. Morrison sent for me, and said, that as our proceeding onwards had made him no better, he wished me to allow him to return, which I did, to see if the sea air would recover him ; I therefore gave Mr. Houtson an order to see him to Jannal,, or to Badagry if necessary, and they parted at 4 P. M.

Saturday, 24th.-Raw cold morning: Captain Pearce much the same, Richard better. At 7 A. M. left Tshow. During last night we had thunder, lightning, and rain; the roads dreadfully bad; in some places over the horses' bellies. In one place George Dawson's horse lay down in the midst of the water, and the rider rolled off, as he was weak and ill with ague. At 10.30 A. M. arrived at $\mathbb{E g a}$; the road mostly through thick woods, with here and there patches of cleared ground planted with corn. Received a present of yams, oranges, eggs, plantains, and a goat. At 4 P. M. George Dawson, seaman, died: he had got the ague at Jannah, where Dr. Morrison had turned him off. I was not aware of his belonging to his majesty's service until after his death, or I should have sent him down to his ship the moment of his discharge at Jannah. I caused him to be decently buried, and read the service over the body, making all the servants that were able to attend the ceremony.

Sunday, 25th. - Our poor sick still remain much the same. I also have been very ill from a cold caught on the journey of yesterday. The country continues to be diversified with hill and dale, and in many places well cultivated. The approach to Emadoo is through a long, broad, and beautiful avenue of the tallest trees; a strong stockade eighteen feet high, with a wicker gate, and at one hundred paces from this another of the same kind, defends the entrance to the town. The road from Ega to Liabo was 
beautiful, rising ground, gentle hills and dales, a small stream of water running through each valley: the land partly in a state of cultivation, and sufficiently cleared of that thick forest which gives such a monotony to this part of Africa. At 9 A. M. halted at a town called Ekwa, where we received a present of yams, plantains, and a goat.

Monday, 26th.-Raw, cloudy morning. All the towns from Jannah to Ekwa are situated in the bosom of an inaccessible wood; the approach is through an avenue defended by three stockades with narrow wicket gates and only one entrance; but Liabo only had a mud wall and ditch in addition to the stockades.

Tuesday, 27 th.-Morning clear for the first time since we left Jannah-a strong wind blowing-our sick and myself the samehad them well wrapped up in their hammocks. I suffered much from cold, being lightly dressed. After leaving Ekwa we crossed a deep ravine, and descended a hill on the ridge of which we travelled until we arrived at Engwa, at $9 \mathrm{~A}$. M.

At 11 A. M. Pearce had become much worse and quite insensible; and at nine in the evening he breathed his last. From the moment of Captain Pearce's being taken ill, his wonted spirits supported him through the progress of a disease that was evidently wasting his strength from day to day; but after Dr. Morrison left' us, he became less sanguine of recovery, and wished Richard to remain in his room to keep him company, as my duties in attending to the business of the mission prevented me from being as much with him as I could have wished. On the morning of our leaving Tshow I gave him some bark, but afterwards the heat of his skin was so great, that I thought it prudent not to give him any more, and he was too weak to venture on any strong medicine. The death of Captain Pearce has caused me much concern, for independently of his amiable qualities as a friend and companion, he was eminently qualified by his talents, his perseverance, and his fortitude to be of singular service to the mission, and on these accounts I 
deplore his loss as the greatest I could have sustained, both as regards my private feelings and the public service.

Vednesday, 28th.-At eleven this morning I interred the remains of Captain Pearce, the whole of the principal people of the town attending, and all the servants. The grave was staked round by the inhabitants and a shed built over it: at the head of the grave, an inscription was carved on a board by Richard, I being unable to assist or even to sit up.

Saturday, 31st.-As I had heard nothing from Mr. Houtson as to the fate of Dr. Morrison, I determined to wait here until I should get a little stronger. In the evening, however, Mr. Houtson arrived, who informed me that Dr. Morrison had died at Jannah on the same day as Captain Pearce.

With the assistance (says Mr. Houtson) of old Accra, and the caboceer's messenger, I had the body washed and dressed, and at 8 A.M. on the morning of the 28th buried him at the south-west end of the house we lived in ; the king's messenger and a number of people attending. I read the church of England service over his remains, and paid all the respect that circumstances permitted. I sent to Badagry for a head board with an inscription stating his name and the date and place of his death.

'Tuesday, January 3d, 1826.-Left the town of Engwa in a hammock, and reached the town of Afoora, where we were well lodged, and had a present of yams, fowls, a goat, \&c. 'The town is surrounded by a stockade; the state of the atmosphere much changed for the better.

Wednesday, 4th. - Clear and cool, all of us much better. At 7.50. left Afoora. The country clear, and rising into hill and dale : on the rising grounds large blocks of gray granite showed their heads above the earth; the plains were scattered with the female cocoanut, and covered with long high grass, which in many places had recently been burnt down. 'Ihe view on leaving Afoora was beautiful 
from the hills; all the valleys being filled with streams of water rumning to the north-west, to join a larger river said to empty itself into the Lagos. Halted at the town of Assulah, and received plenty of yams, fowls, plantains, eggs, and a goat ; the inlabitants were as usual very kind and civil, and may consist of five or six thousand people: the town is surrounded by a new made ditch, on account of the existing war, and they are building a number of houses; the women are very shy, and they say that adultery is punished with death.

Thursday, 5th.-Left the town of Assula, and passed through the village of Itallia. 'The country to-day very beautiful. Arrived at Assoudo: it is a walled town, and as far as my observation goes, at least 10,000 inhabitants. We received a plentiful supply of provisions, wood, and water. The people here are as curious as at other places, but very civil. Houtson and I rode out at sunset, and were surrounded by thousands; the men kept dancing and the women singing all night on account of our arrival.

Friday, 6 tl.. - We left the town of A ssoudo: the country naturally clear of wood, and planted with cotton and corn; the succession of hill and dale beautiful. We halted for the night at the town of Chocho. 'The caboceer out hunting, as he did not expect us to-day. All the men in the place were with him, hunting the wild buffalo. We got the best house the town afforded. In the evening the caboceer arrived, and we received a present of yams, plantains, eggs, and a goat. This town is pleasantly situated among the rocky hills, but the inhabitants not numerous.

Saturday, 7th.-On leaving Chocho our road lay through beautiful rocky valleys, cultivated in many places and planted witls cotton, corn, yams, and bananas; and well watered with many fine streams. A number of little towns are perched on the top and in the hollows of the hills, to whose inhabitants the plantations in the valley belong. A war is now carrying on only a few hours' ride 
from us : not a national but a slaving war. We were supplied with yams, eggs, and plantains, a goat and fowls. The caboceer did not make his appearance: I therefore told the king's messenger that I should inform the king of Eyeo of this caboceer's want of respect.

Sunday, 8th.- Last night we had thunder, lightning, and rain ; the morning dull and cloudy: at 8 A.M. left Bendekka, our road through winding and beautiful valleys formed by the rugged and gigantic blocks of granite, which in some places rose to the height of six or seven hundred feet above the valleys in which we travelled. Sometimes the valley is not a hundred yards broad, at others it may widen out to half a mile; in one place we harl to travel over a wide mountain plain. 'The soil is rich, but shallow, except alongside the fine streams of water which run through the valleys, where large tall trees were growing; the sides of the mountains are bare except in the crevices, which are filled with stunted trees and shrubs. 'The valleys well cultivated, and planted with cotton, corn, yams, \&c. At 12.30. P.M. arrived at the town of Duffoo, where we were well lodged; but the crowds of people were immense: when told to go away, they said-No; if white man would not come out, they would come in to see him.

This cluster of hills said to rise in the Berghoo country, which is behind Ashantee, and to run eastward through Jaboo to Benin. They do not know their direction any farther. They extend from W.N.W. to to E.S.E. ; and are about 80 miles in width from north to south.

'The king of Eyeo's wives are to be found in every place trading for him, and, like other women of the common class, carrying large loads on their heads from town to town. Mr. Houtson and I went to the top of one of the mounts: I had to be assisted by two men, being so weak I could not go alone. We had a grand and beautiful view of mountains, precipices, and valleys, wherever we turned our eyes, with the town of Duffoo spread out at our feet. The top of the hill was covered with women grinding corn. They make round 
holes in the face of the rock in which they crush the grain with a small stone in the hand. 'This mount may be called a large corn mill.

This evening the fetish went round to keep away thieves. These watchmen make a noise resembling that which a boy does by spinning a notched stick tied to a string, round his head. When this is heard, no one, on pain of death, must stir out of his house.

Monday, 9th.-Left Duffoo, a town that may contain upwards of fifteen thousand people. Mr. Houtson unwell; he rode on early to avoid the sun. I had great trouble in getting hammock-men. After leaving Duffoo, the road winding around between two hills, descending over rugged rocks and stones, and immense blocks of granite overhanging us, as ready to start from their base to the destruction of every thing below. About half a mile came to the village of Jesin, close at the base of five towering rocky hills, and surrounded by tall trees, a small stream running through it; from this the road ascends and descends, still winding round the hills, until we arrived at the town of Weza. Here our carriers would not start until they had quaffed an immense calabash of otée, (mountain ale made from millet), which the caboceer of the town sent to me with some plantains and eggs: the last article in this country almost invariably half-hatched. We now passed over a table land, gently descending from the mountains, well cultivated and watered with several streams; halted at the town of Chiadoo, situated on the side of a gently rising hill, surrounded by a wall and ditch; and within the walls thickly planted with a belt of trees, which entirely surround the town.

'Tuesday, 10th.- The caboceer of this town is a friend of the caboceer of Jannah, and extremely kind and attentive. He hopes our stay may be extended to ten days, and assures us that neither we nor our people should find any want of provisions. He sent us abundance of yams, fowls, a goat and a turkey; the last a rare fowl in this country. 'The caboceer's name is Toko. I have put the barometer up, and shall wait two days. Mr. Houtson better; 
myself unwell, with head-ache, languor, and weakness; Richard much better, but still weak.

Wednesday, 11th._Calm and clear. The caboceer waited on us to-day, when we gave him ten coral beads for a piece of cloth, with which he was much pleased. This town of Chiadoo is large, and I think contains upwards of 7000 inhabitants, whose curiosity regarding us is insatiable, crowding the square whenever we make our appearance.

Thursday, 12th.-The morning dull and cloudy. About eight o'clock left Chiadoo; the caboceer, and an immense train of men, women, and children, attending us; the women singing in chorus, while the drums, horns, and gongs, formed a strange discord with their agreeable voices : the road, through a well cultivated country, apparently descending through the rude and rugged pass between the hills. 'The soil a fine mould, but very thinly strewed over the granite base, which in many places on the plain broke out and appeared like large sheets of water glittering in the sum. At 10 halted at the town of Matoni (signifying "Let me alone"), where we took leave of the caboceer. We staid but a few minutes, while the carriers had swigged a few calabashes of mountain ale, or otée, as it is called in their language. 'The road was now very difficult and dangerous, over broken rocks, and through rugged passes, where the inhabitants were perched in groups to look at us as we passed by. At one halted at the town of Erawa, where we were received with drums; the caboceer conducted us to his house and gave us fowls, sheep, and a goat ; and the caboceer of a neighbouring town sent us a pig. The people were here curious beyond measure, yet exceedingly kind. The town is large and very populous.

Friday, 13th.-Dull and hazy. The caboceer, on coming to bid us good morning, said that our guide had not told him that we wished to go away to-day, a manouvre of the caboceer and the guide to detain us, so that all the people might have an opportunity of seeing us : but we were determined to proceed; and after much 
palaver about hammock-men and carriers, left Erawa at nine: the road through a mountain pass as far as a town called Washoo, where we rested. After this we again entered the mountains. At 2. 30 P.M. arrived at Chaki. The country from Erawa to Chaki well planted and thickly inhabited, till we entered the last mentioned mountains, which were more broken than those we had hitherto passed, and appeared as if some great convulsion of nature had thrown the immense masses of granite into wild and terrific confusion. The road through this mountain pass was grand and imposing, sometimes rising almost perpendicularly, and then descending in the midst of rocks into deep dells; then winding beautifully round the side of a steep hill, the rocks above overhanging us in fearful uncertainty. In every cleft of the hills, wherever there appeared the least soil, were cottages, surrounded by small plantations of millet, yams, or plantains, giving a beautiful variety to the rude scenery. 'The road continued rising, hill above hill, for at least two miles, until our arrival at the large and populous town of Chaki, situated on the top of the very highest hill. On every hand, on the hills, on the rocks, and crowding on the road, the inhabitants were assembled in thousands; the women welcoming us with holding up their hands and chanting choral songs, and the men with the usual salutations and every demonstration of joy. 'The caboceer was seated on the outside of his house, surrounded by his ladies, his singing men and singing women, his drums, fifes, and gong-gongs. $\mathrm{He}$ is a good-looking man, about fifty years of age, and has a pleasing countenance. His house was all ready for us; and he immediately ordered us a large supply of goats, sheep, and yams; pressing us strongly to stay a day or two with him. He appeared to consider us as messengers of peace, come with blessings to his king and country. Indeed a belief is very prevalent, and seems to have gone before us all the way, that we are charged with a commission to make peace wherever there is war; and to do good to every country through which we pass. The 
caboceer of this town indeed told us so; and said he hoped that we should settle the war with the Nyffee people and the Fellatah; and the rebellion of the Housa slaves, who have risen against the king of Yarriba. When I shook hands with him, he passed his hand over the heads of his chiefs, as confirming on them a white man's blessing. He was more inquisitive and more communicative than any one whom we have yet seen. He sat until near midnight, talking and inquiring about England. On asking if he would send one of his sons to see our country, he rose up with alacrity, and said he would go himself. He inquired how many wives an Englishman had? Being told only one, he seemed much astonished, and laughed greatly, as did all his people. "What does he do," said he, "when one of his wives has a child? Our caboceer has two thousand."

We learned from this man that the Niger, or Quorra, passed Jaboo, and entered the sea at Benin, but that it flowed over rocks; that Burgho is only one day's ride north-north-west, and that the mountains through which we are travelling pass through Ghunga, thirty-five days distant from hence west-north-west; that they continue through Burgho, Youriba, and Laboo, to Benin; but of their further course he was ignorant. This was confirmed by the king of Burgho's messenger, who was present. On asking for milk he sent for it, and said, that if we wished to wash in milk there was abundance for us all. Abaco, our guide, told us this caboceer held great authority under the king of Eyeo, and had an extensive district of country, and many large towns, under his regency. He appeared a true mountain king, and the friend of strangers; his name is 'Toko, and he is fond of our tea.

Saturday, 14th.-Clear, and a fine breeze from the westward; much difficulty in getting away the people, and caboceer wishing us to stay. At 8,40 A.M. started, accompanied several miles by 
the caboceer and a great number of people, with upwards of two hundred of the caboceer's wives, one of which was young and beautiful. The messenger from Burgho also was with us, and mounted on a much better horse than any I had yet seen. He said it was a war-horse, and set much value on it. Passed through the village of Fellah : the country extremely beautiful, clear of wood, and partly cultivated. We passed a number of Fellatah villages, whose inhabitants live here as they do in most other parts of Africa, attending to the pasturage of their cattle, without interfering in the customs of the country, or the natives giving them any molestation. Passed Awari at ten; at eleven started again and halted at Bayoo; the country still continuing fine and well cultivated. Here we changed carriers; and at 1. 40 P.M. arrived at Kooso, a large, double-walled town; the outer wall extending from some rugged granite hills on the south-east to a great distance in the plain : the walls were crowded with people to receive and welcome us. 'The caboceer was seated under his verandah, with his wives and headmen around him, and shortly after came to welcome us. He was dressed in a Nyffee tobe, made after the Mohammedan fashion. He said he was glad to see white men come to his country, and going to see his king; that he never expected to see this day; that all the wars and bad palavers would now be settled. He presented us with yams, eggs, a goat, a sheep, and a fine fat turkey, and milk : a large pig also from the caboceer of a neighbouring town.

Sunday, 15th._Clear and cool breeze from the east. The caboceer came to bid us good morning, bringing abundance of provisions, which we gave to the kafila accompanying the messenger. The large court, about two hundred yards square, in which we are lodged, is constantly filled with some thousands of people, who will not be driven away, party succeeding party in their curiosity to see us; and "wide-mouthed wonder stares apace." This is by 
much the largest town we have seen, and at least contains twenty thousand people. They describe the country on every side as being full of large towns.

Monday, 16th.-Morning clear and fine. Last night we had thunder, lightning, and a few drops of rain; the thermometer had been as low as sixty-two degrees. They tried very hard this morning to retain us another day, but we were determined to go on, and at eight we left Kooso. I rode to-day, as I felt myself much stronger than since I left Engwa. Just as we were starting, Mr. Houtson being mounted on a vicious horse, the animal reared and fell backwards with him. Our road was in a parallel line with the hills until we passed through the town of Yaboo; course, east three-quarters north; the country well cultivated and very beautiful. At 10 A.M. halted at the town of Ensookosoo; here we had to stop, much against our will, as Abaco, the messenger, had eaten too much pork, and made himself sick, and could proceed no farther. We therefore took up our quarters in the house of the caboceer, a dull-looking man, with a long iron chain round his neck, an ornament of which they are all fond: a pair of manacles for the hands lay beside him. We were lodged in the fetish room, which was the best in the house, and a very good one. We had a present of a pig, fowls, guinea-fowl, goat, fruits, milk, two bushels of plantains, yams, \&c. The country between Yaboo and Ensookosoo was a beautiful plain, well cultivated, and studded with a number of Fellatalı villages; here also the curiosity of the people appeared to be insatiable, but the women very shy; they are well dressed, and have immense large bugles on their arms, the Fellatah women who came from the villages to see us especially, as also their necks covered with coarse jasper beads, made in the country : we met a number of people with merchandize. The people snap their fingers when the caboceer drinks.

Tuesday, 1\%th.-Last night we had a long conversation about 
England; and the belief of my going to make peace with the Housa slaves and the king gains ground. They have been in rebellion these two years, and possess a large town only two days' journey from Katunga, called Lori. 'The Youribanis are evidently afraid of them ; they say they have a great number of horses, and have been joined by many Fellatahs. I told them, that if the king made good friends with the king of England, he would send him every thing he wanted; that if ships could come up the Quorra there would be an end of the war immediately. They said that canoes came up the river from Chekerie or Warrie to Nyfree or Tappa, and that they were ten days on the passage. I surprised them not a little by an account of our rivers, towers, houses, and especially our great guns. We had a great deal of trouble in leaving Ensookosoo, and it was 8.45 before we got fairly started. The Fellatahs near the town had supplied us with plenty of milk; we had guards inside and outside the house, and the war-horn blowing at intervals all night. At 9.15 halted at the town of Ladooli; the country is well cultivated, with numerous villages. We met numbers of trading men and women, and saw a range of hills bearing from east by south to south. After changing horses we left Ladooli, and halted at Aggidiba; the country well cultivated as before, but the inhabitants had mostly deserted from the town on account of the rebellious Housas, who make frequent inroads into this part of the country, and have burnt several towns and villages. I stopped here, as I was very sick, and unable to ride; but at 12.15 left Aggidiba; our road through a wood of low, stunted, scrubby trees, on a soil of sand and gravel; passed three villages, and two that had been burnt by the Fellatahs. At noon arrived at the town of Akkibosa: it is surrounded with trees inside the walls. The caboceer was very civil, and made us a present of a goat, yams, fowls, eggs without number, and plantains. These two days we have not seen the palm-oil tree, but one of 
them appeared to-day by the banks of a small stream in the valley. Mr. Houtson and I took some strong medicine, as we were both very unwell. I was worse than I have been since I left Badagry. The town of Akkibosa is large, and surrounded inside the walls with an impenetrable wood.

Wednesday, 18th.-Morning dull and hazy, with a little drizzling rain. At 7 A. M. left Akkibosa; the country cultivated only in patches here and there; the trees low and stunted; the soil gravelly. At 9. 20 halted at Adja, where we were obliged to stop, the people being at work in the fields. The caboceer seemed inchined to be uncivil, and did not wait on us for a considerable time: when he did, I would not shake hands with him, but told him I should report his disrespectful conduct to the king of Eyeo. He first said he was in the country, then that he was asleep, and no one toid him we were come. He said, if I would forgive him, he would get us every thing we wanted; to which I assented, provided he would promise to get us every thing ready for starting at daylight. I had my side rubbed with a piece of cord; after some Mallageta pepper was chewed and spit on the part. The cord was rubbed backwards and forwards on the part, and gave ease; and I consider it an excellent mode of rubbing.

Thursday, 19th._Clear morning. Every thing was ready at daylight. The caboceer brought me some medicine to take; it was like lime-juice and pepper. I was so sick that I could not stand for half an hour after I had taken it; I then got suddenly well, both as to the pain in my side and the severe diarrhoea which had troubled me for some clays: gave him six coral beads, and at 6. $40 \mathrm{~A}$. M. left Adja, which is a walled town, having an avenue of trees, with a creeping plant of a briar-like appearance ascending to their very tops, from which hanging down, it makes an impenetrable defence against any thing but a snake; and being an evergreen, there is no possibility of burning it. 'The town is 
straggling, and may be said to contain 4000 inhabitants. At $S A . M$. passed the town of Loko, where we changed carriers : the country well cultivated, and planted with corn, yams, \&c., and rising into gentle hills and dales. At 8.30 left Loko, which is a considerable walled town; at 9.30 halted under a tree to tighten my hammock; at 10 halted at the eastern town of Saloo; there being three of that name close together, and all apparently equally large; the western one walled, the other two not walled. The country between Loko and this place but little cultivated, and thickly wooded; the soil a red clay and gravel, with some large pieces of clay iron-stone that looks as if it had passed through the fire, being full of small holes, perhaps by the water wearing away the soft parts. In this part of the route I obtained the flower of the butter tree of Mungo Park. 'The tree is almost bare of leaves when in flower, and until the rains are nearly over, and is then in luxuriant foliage. The flower has eight petals and eight leaves, and of a pale yellow. At 10. 30 changed carriers and left Saloo; at noon, halted at the town of Laydoo. The caboceer's house was under repairs, but we got a good room, with plenty of provisions. He sent into the country for milk and honey; the latter we got; the former not to be had. We here saw a great number of traders.

Friday, 20th.-Morning clear. Last night we had a visit from the caboceer and the principal people of the town, to inquire what would make their town large and flourishing as it once was. I told them, that to encourage people to come and settle in it by treating them well, and also to encourage them to come and trade, and plant plenty of corn and yams, and then poor people would make money, and get children; that no man ought to have one hundred wives and another none, but that every man ought to have only one wife. The latter part of my advice was laughed at, though the first was highly approved. I told them, if 
they had only one wife, more children would be born: that in England the people are as numerous as ants; and that I was the youngest of thirteen children, and as stout a man as any in their town; that it was no uncommon thing for one woman to have sixteen or seventeen children. Mr. Houtson then gave them a word on the riches, improvements, and happiness of Old England, enlarging on the general cultivation of the country, its roads, carriages, and modes of travelling; its canals, ships, trade, wars, \&c. ; the bravery of the men, and the beauty of the women, with the richness of their dress ; and that this prosperous state of things resulted from its good government, the king encouraging people from all parts of the world to come to England and trade, and sending his own people to visit the most distant corners of the earth to see what in every country might be of use in England. It was midnight before we parted, and then I had to send them away, telling them we had to rise early in the morning. Burgho is only a day's journey from this, and the natives of that country often come and steal people from the neighbouring towns to sell into slavery. At 7 A. M. left Laydoo; the country but little cultivated, thin woods, soil a red clay mixed with lumps of iron-stone, none being larger than three feet on each side. At 8.30 halted at the village of Leogalla, inhabited by Fellatahs, who kindly brought us sweet milk to drink. At 10 halted at the village of Bongbong, where the carriers got their breakfast of eko, or accassan, which is made of millet meal, first steeped in water until sour, then boiled like a thick paste, and then mixed with warm or cold water for a drink, or eaten without water for food: it is very wholesome. The village of Bongbong is walled. At 10.30 started-passed a burnt village -the road winding-country woody, forming gentle dale and down; a strong harmattan, or north wind, blowing. At noon halted at Atepa ; got quarters in the caboceer's house, where we were supplied with yams, fowls, a goat, turkey, \&c., also a large pig, which 
we gave to Abaco, the king's messenger. The caboceer was very inquisitive about England.

Saturday, 21st.-Morning cold and clear. This night the thermometer has been as low as $55^{\circ}$ in the open air. The coldest time in this country, as, I believe, in all others, is the hour before daylight, or rather before sumrise. The town is large and populous, containing certainly above six thousand; it is surrounded by a belt of trees, rendered impenetrable by the crossing thorny creepers, through which there is only a narrow pass at the gates. The country, for a couple of miles outside the gate, well cultivated. At 9.15 entered the walled town of Namah, the road now winding and woody ; changed carriers ; and at 9.30 left Namah. The country plain, and a clay soil. At 10 A. M. crossed a stream called Juffee or Moussa which runs into the Quorra at, or opposite to, Nyffee. At 11.30 arrived at the walled town of Leobadda : there is a range of broken rocks, like an immense wall, on the east side of which the town is built. We were accompanied hither by the caboceers of Atepa and Namah, with all their train, to guard us from the Burgho robbers who frequent the road, as the king of that country has his capital only one day's journey with a horse from this place. Passed two ruined villages; the road woody and winding. We gave the two caboceers a dram before starting, as they had been very kind to us.

Sunday, 22d.-Clear and cold; north wind during the night; thermometer, $56^{\circ}$. The town of Leobadda is situated on the east side of a ridge of granite, the tops of which are broken into large masses, some of them forming the most grotesque figures imaginable; they run in a direction from north-east to south-west, and are from fifty to sixty feet above the plain, and join the hills to the south and east. Leobadda contains about one hundred and fifty houses, with from thirty to forty souls in each ; it is walled; the inhabitants are poor, but civil; we were well supplied with provisions, 
as before, and in addition had milk. The caboceer told us that Kiama, the capital of Borgho, was only one day's journey by a horse from his town; that these people were only a band of thieves; that their country was small, but independent; that they infested the roads of Youriba, and stole all they could catch.

At 7 A. M. started, accompanied by the caboceer and a great number of attendants. The country well cultivated for a little way outside the town. We met upwards of six hundred men, women, and children, carrying loads; they had travelled all night, and were guarded by men with bows and arrows and swords, ten or twelve armed men marching between each fifty; the road woody, but the trees low and stunted. Here, for the first time, I saw the small stunted accacia. The soil red clay. Passed several villages that had been destroyed by the Fellatahs, some very large. The shady trees are now desolate, the walls covered with weeds. After closing with the range of rocks we entered a beautiful valley in the midst of them, planted with large shady trees and bananas, having green plots, and sheets of water running through the centre, where the dingy beauties of Tshow were washing their well-formed limbs, while the sheep and goats were grazing around on the verdant banks. After passing this lovely valley we crossed another ridge of rocks, and at 9.15 arrived at the town of Tshow, where, after getting housed, we turned to and cleaned our arms, as they say the road is infested with robbers. We afterwards heard that the king of Eyeo was going to send an escort, and was quite rejoiced at our near approach. Got a specimen of the Tsheu fruit and leaves: the fruit is the size of a large pear, having a stone inside, covered with a pulpy cream-coloured substance, which is good to eat. The stone is said to be poisonous; the outer rind of the fruit is put into their soup.

After sunset a caboceer arrived from the king of Katunga or Eyeo. His attendants, horse and foot, were so numerous that 
every corner was filled with them, and they kept drumming, blowing, dancing, and singing all night. The caboceer waited on us, and after shaking hands with us, rubbed all his face and body over, that his hands, by touching ours, might impart our blessing to his face, head, and body. They were well dressed, and said the king of Eyeo was most anxious to see us: they had a great deal of natural goodbreeding; and on my saying I had brought only a small present, they replied, if I had brought nothing the king of Eyeo would be glad to see us. Sent them a flask of rum. They kept firing all night.

Monday, 23d.-The town of T'show was all bustle and hubbub with the great men and their attendants, the large grooms and their little horses. I left it early, being a poor place, with a good wall, and may contain four thousand inhabitants. Perhaps I might call them poor, as they had not fed us so well as we had been wont to be fed; but considering the ravenous host which came to escort us to Katunga, and who live pretty freely wherever they can, this deficiency on our side is easily accounted for. The road through which we passed was wide, though woody, and covered by men on horseback, and bowmen on foot. The horsemen armed with two or three long spears hurrying on as fast as they could get us to go; horns and country drums beating and blowing before and behind; some of the horsemen dressed in the most grotesque manner; others covered all over with charms. The bowmen also had their natty little hats and feathers, with the jebus, or leathern pouch, hanging by their side. These men always appeared to me to be the best troops in this country and Soudan, from their lightness and activity. The horsemen however are but ill mounted; the animals are small and badly dressed, their saddles so ill secured, and the rider sits so clumsily on his seat, that any Englishmen, who ever rode a horse with an English saddle, would upset one of them the first charge with a long stick.

We were also accompanied by great numbers of merchants or 
traders. At 9 A.M. halted to the southward of a village called Achoran, until the baggage should come up; but the heavy packages not coming soon, the caboceers thinking we would be too much exhausted before we got into Katunga, sent us off with a proper escort, waiting themselves for the baggage. At 9.30 left the shade, and went on as hard as the horses could possibly walk; the road winding and woody; clay iron-stone, resembling lava, in the spaces between the granite, great blocks of which appeared on each side of the ravines and low hills. We had from the top of one of the ridges some beautiful views to the east, of fine wooded valleys and low rugged bare hills in the back ground. At 10.20 crossed a stream running to the Quorra, which is only a journey of three days distant. Here we drank and gave our horses water; passed the ruins of two towns burned by the Fellatahs. At 11. 30, from the top of a high ridge, on which were the ruins of a clay wall, we saw the city of Katunga or Eyeo. Between us and it lay a finely cultivated valley, extending as far as the eye could reach to the westward; our view intercepted to the eastward by a high rock, broken into larger blocks, with a singular top; the city lying, as it were, below us, surrounded and studded with green shady trees, forming a belt round the base of a rocky mountain, composed of granite, of about three miles in length, forming as beautiful a view as I ever saw.

At 12.15 we entered the north gate of Katunga; there was a small Fetish house outside the gate, and a few others inside. We halted, and went into one of the caboceer's houses until the baggage and escort came up. Here we got accassan; and Abaco's wife was cooking a little country soup for us, but the pot broke on the fire just as it was ready, and the house was in an uproar in an instant; only for my interference they would have come to blows. Abaco was ready to cry that he had disappointed us.

At 2 P.M. the baggage having all arrived, a message came from 
the king to say that he wanted to see us. A band of music accompanied us and the escort, with an immense multitude of men, women, and children. As there was much open and cultivated ground, the dust they caused almost suffocated us, though the escort tried all gentle means to keep them off. At last after riding one hour, which was full five miles, we came to the place where the king was sitting under the verandah of his house, marked by two red and blue cloth umbrellas, supported by large poles held by slaves, with the staff resting on the ground. After the head caboceers had held some conversation with the king, they came back to us, and I thought they were talking about our prostrations. I told them if any such thing was proposed, I should instantly go back; that all the ceremony I would submit to should be to take off my hat, make a bow, and shake hands with his majesty, if he pleased. They went and informed the king, and came back and said I should make only the ceremony $I$ had proposed. We accordingly went forwards: the king's people had a great deal to do to make way amongst the crowd, and allow us to go in regular order. Sticks and whips were used, though generally in a good-natured manner; and I cannot help remarking on this, as on all other occasions of this kind, that the Youribas appear to be a mild and kind people, kind to their wives and children and to one another, and that the government, though absolute, is conducted with the greatest mildness. After we got as far as the two umbrellas in front, the space was all clear before the king, and for about twenty yards on each side. We walked up to the verandah with our hats on, until we came into the shade, when we took off our hats, made a bow, and shook hands; he lifting our hands up three times, repeating "Ako, Ako," (how do you do?) the women behind him standing up and cheering us, calling out "Oh, oh, oh !" (hurrah!) the men on the outside joining. It was impossible to count the number of his ladies, they were so densely packed and so very numerous. If I might judge by their smiles, 
they appeared as glad to see us as their master. 'The king was dressed in a white tobe, or large shirt, with a blue one under; round his neck some three strings of large blue cut-glass beads; and on his head the imitation of an European crown of blue cotton covered over pasteboard, made apparently by some European, and sent up to him from the coast. We waited about half an hour until all inquiries had been made respecting our health and the fatigues of our journey. We were then conducted by his chief eunuch and confidents to apartments in the king's house, and asked if we liked them. They certainly were very good; but our servants would have been too far removed from us. We looked out for one in which we could be more comfortably stowed, and one by which both servants and baggage would be under our own eyes; which is an important matter, in this country especially, and never to be neglected, however good the servants may be. After this we had dinner and tea, to which we had good new milk; and when it got fairly dark we had a visit from the king in person : he was attended by his favourite eunuch, the ladies remaining outside. He was very plainly dressed, so that he would not have been known outside but as one of the people, with a long staff in his hand. He said he could not sleep until he saw us, but that we should only talk about our health, and not about business now. After a short stay he went away. We requested before he went that we should be left undisturbed for two days, that we might rest from the fatigues of our journey. 


\section{CHAPTER II.}

RESIDENCE AT EYEO, OR KATUNGa, THE CAPITAL OF YOURIBA.

Tuesday, January 24th.-Early this morning the king paid us a visit, accompanied by his farourite eunuch and Abaco the messenger. He had received previous information that he wished to have the presents intended for him this night; and such is the crooked policy of these petty sovereigns of Africa, that no present can be given, no business or transaction of importance can be done openly: all must be conducted under the cover of night, and with the greatest secrecy, from the highest to the lowest. We first began inquiring after his health. I then told him that I was the king of England's servant, sent by his majesty to beg his acceptance of a present, which then lay before me; that we had heard his (the king of Youriba's) name mentioned in England as a great king; that we now experienced the truth of the report; that three white men, two of them my companions, and one a servant, had died on the road; that another of my companions was at Dahomey, to ask the king of that country to allow him a passage through his dominions. I told him that all the Youriba people had behaved well to us; that the caboceers of the different towns through which we had passed supplied us with every thing we wanted, especially the chief of Jannah, his friend, who had shown the greatest attention to us, and had given us a good man for a messenger, who had conducted us with safety and attention to his majesty's capital. Upon this the messenger was ordered to make his prostrations, and his majesty rubbed his shoulders with his hand. I then told him that 
the king of England would be glad to make him his friend, and that whatever he, the king of Youriba, might have occasion for would be sent from England by one of the king's ships to Badagry.

The king then replied in assuring us that we were truly welcome to his country; that he had frequently heard of white men; but that neither himself, nor his father, nor any of his ancestors had ever seen one. He was glad that white men had come at this time; and now he trusted his country would be put right, his enemies brought to submission, and he would be enabled to build up his father's house, which war had destroyed. 'This he spoke in such a feeling and energetic manner, and repeated it so many times, that I could not help sympathising with him. He then said we were welcome to his country, and he was glad to see us, and would have been so, even if we had not a cowrie, instead of coming with our hands full, as we had done; that he wanted nothing from white men, but something to assist him against his enemies, and those of his people who had rebelled against him, so as to enable him to reduce them to obedience; that his slaves from Housa had joined the Fellatahs, put to death the old, and sold the young; that he was glad to hear that all his people had behaved well to us; that had any of them refused us assistance, he should have sent an order to cut off their heads; that the caboceer of Jannah was his slave, whom he put there to look after that part of his dominions; that Badagry, Alladah, and Dahomey all belonged to him, and paid custom for every ship that anchored there: and he concluded by assuring us he wanted nothing but assistance against his enemies; feelingly deploring the civil war occasioned by his father's death, the state of his country, and of his capital, Katunga. He then asked us if we did not see the ruined towns as we came along the road. "All these," says he, "were destroyed and burned by my rebellious Housa slaves, and their friends, the Fellatahs."

We now began to unfold and to deliver the presents. With the 
umbrellas and gold-mounted cane he was much pleased; but for the red and blue cloth, which, by some mistake, was common cloth for soldiers' coats, we had to make an apology. With all the others he was highly pleased. Indeed, during our stay at Katunga he was never seen without the cane.

After the delivery of the presents, I told him that the king, my master, had sent me before on a mission to Bornou, in which country and Housa I had passed two years; that the sultans and people of these countries had behaved to me with the greatest kindness; and that, having then understood that the path we were now going was the nearest way to Bornou, the king of England had ordered me, as I proceeded, to visit the king of Youriba, and to assure him of his friendship, and to request him to give me a safe conduct to Nyffee, from whence I might proceed to Bornou.

He seemed to hesitate much at this request, and consulted with his minister what answer to give. After which, he said, that Nyffee or 'Toppa was involved in civil war, caused by the death of the king, who had left two sons, both of whom claimed the kingdom; that one son had more of his countrymen on his side, but the other had called in the assistance of the Fellatahs or Fellans, which made him doubt as to my safety, in the event of his putting me into their hands. I told him I was a servant of the king of England, and must go where he chose to order me, and that, live or die, I must proceed; that I had nothing to do with either party or with their wars; that all I wanted was a passage over the Quorra into Nyffee, and hoped he would not refuse me. After some further consultation with his counsellors, he said he would despatch a messenger to open the road for me, and that he would send me safely over the river.

Wednesday, 25th. - Early this morning the king sent me a present of a large fat cow, a sheep, yams, \&c. He had before sent us a goat, yams, honey, and milk, night and morning. 
The atmosphere here is so dry, that most of the instruments are breaking and splitting. My only hygrometer was broken at Badagry. The late Dr. Morrison's barometers were fitted with ivory screws at the bottom of the tube; they are all split, and rendered useless by the heat: the plain tubes are the best; those with ivory or wooden scales contract, and break the glass. 'I he microscope is all in pieces, as also several other instruments.

In the evening we had a visit from the king, to thank me for the presents I had given him, and again to assure me of being welcome; said that he wanted nothing, unless it was something that would speedily cause the submission of the rebels. He said that he had sent to his friend the king of Benin for troops to assist him in the war. He added that the customary fêtes or amusements would begin in about two months, and he would be very glad if I would stay and see them; that he dressed now as a commion man, but after that, I should see him robed as a king. I told him I must go on early, to get to Bornou before the rains. Mr. Houtson took this opportunity of observing to him that he had been at the customs in Dahomey, and inquired if the king of Yourriba put to death such a number of people at his customs as at those of Dahomey. He shook his head, shrugged up his shoulders, and exclaimed "No, nono king of Yourriba could sacrifice human beings; and that if he so commanded, the king of Dahomey must also desist from that practice ; that he must obey him."

Thursday, 26th.- This morning we had a sheep from the king, and a hog and some plantains from one of his sons. In the evening I set off five rockets, which astonished all and frightened away many. The king was sitting under his verandah, and we waited on him to inquire how he liked the rockets; he was quite delighted, and said they should be kept for war.

Friday, 27th.-Fmployed in reducing the packages, and writing. 
The morning dull and hazy. In the afternonn the king paid us a visit, when we showed him some presents intended for the three principal caboceers of the city. He said he did not know what to do or say for our great kindness, as we had given him more things than he would have got for the sale of one hundred slaves, and now we were giving more to his caboceers ; that, however, what he could do he would. He said he had sent messengers in different directions to try to find a safe path to the place where I wished to go ; that while we were in his dominions we were perfectly safe, but on leaving them he was sorry to think we might be exposed to danger from the disturbed state of the countries through which I must travel. He then said that the 'Iappa, or Nyffe' messengers, who had been here three years, were in waiting to give us every information regarding the course of the river that I might wish to ask him. They were accordingly called in, and were certainly the most savage-looking knaves I ever saw ; but they either could not, or were afraid to give any the least account of the river Quorra, and $I$ therefore sent them off, after asking a few questions. Indeed there seems a great unwillingness in both the king and the people of this place to say any thing at all about the subject, for what reason I cannot yet conjecture.

Saturday, 28th - This morning I set out on horseback on a visit to the three head caboceers, who dwell about three miles from our house. We were received with much kindness and attention by all of them under their respective verandahs, and surrounded by hundreds of their wives, who all clapped their liands in token of welcome. They severally presented us with goats, sheep, pigs, yams, eggs, honey, and ducks, inviting us to drink country ale with them, and to make merry; but I was very unwell, and anxious to get home. In the evening we paid a visit of ceremony to the king, when I asked him to allow Mr. Houtson 
and myself to go and look at the Quorra, and return before closing my despatch for England. He replied, that he heard what we saic!, and that we should go. I also asked for a messenger to carry letters to Badagry in two days hence. He said he would be ready.

Sunday, 29th.-Clear and cool. Very unwell all night with a bad cold, pains in the limbs, and severe headache, with vomiting of bile; took calomel. Richard also weak and unwell.

Monday, 30th._Clear and fine. The harmattan seemingly approaching its end. Better this morning. In the early part of the evening we had no wind, and it is extremely hot.

Tuesday, 31 st. - I have been very restless and unwell all night. The king sent twice to inquire after my health yesterday, and wished to come and see mé; but I was too weak to sit up to receive him. The messenger sent to open the path to Nyffe not yet returned. The king called to see me this evening, but I was asleep; he insisted, however, that Mr. Houtson should allow him to look at me with his own eye, and taking the candle, he did so, and observed, that having looked on me I should be quite well in the morning. Mr. Houtson asked him for the loan of a horse, to take an airing in the morning. This his majesty could not comprehend: what could a man want to ride or walk for nothing? if he rode or walked, he ought to go and see one of the caboceers, and he would get a present of a sheep, or a pig, or some yams; that would be doing good; so he said he would send a horse in the morning, and he must go and see some of his caboceers, and he would send to let them know he was coming. The pain in my head has fallen into my left eye, with inflammation and acute pain, accompanied with a light delirium. Poor Pascoe very unwell.

Wednesday, February 1.-Strong breezes. My eye a little better. Pascoe much better. 'The king, agreeably to his promise, sent a horse and two eunuchs to attend Mr. Houtson in 
his ride. He visited one caboceer, and was about to return home, when the whole of the party begged he would visit another, or all the caboceers would make a palaver with this one. Mr. Houtson went accordingly to see the other caboceers; he was received witl great kindness and attention, and came home with a supply of eggs, milk, honey, two goats, a pig, two ducks, and plantains, \&c. He objected to receiving presents, but they told him the king's friends could not come to their houses, and go away empty-handed.

Sunday, 5th.-Morning clear, and a fresh breeze. In the afternoon had a visit from his majesty. I asked him if the Nyffé messenger had arrived. Ile said, no; that he must be dead, sick, or taken prisoner. Ile said we could not go by the road of Nyffe, which was impassable from the wars: what was my hurry to go? He was not yet tired of me; he had many caboceers coming from the country to see me ; he wished to put every thing right on the roads for me before I set off; that the king of England did not send me to him to rum away again directly; that he wished me much to wait and see the customs, for then I should see lim truly a king. I said I would do so with pleasure, but that the rains would have set in by that time, and I should be unable to go to Bornou. He asked what I was going to Bornou for. "Did not the king of England send you to me alone?" "No," said I, "he sent me to you to procure me a passage to that country, where an Englishman now resides who was left there when I returned from thence." I then told him I would consent to remain twelve days longer, and if he did not by that time find me a passage, I would return to England and say he would not allow me to proceed. He now informed me that the messenger who arrived yesterday was from one of his provinces called Yaru, five days distance; that it was divided from the Youri by the Quorra; that he would send me by that route, which was quite safe. I asked if I could not go and see the Quorra before I departed from Katunga. He said no: the Fellatahs had 
possession of the road. He gave me his gooro-nut box, carved in the shape of a tortoise in ebony. I promised to let him have thirty musquets, with powder and ball ; on which he went away dancing, tripped and fell, but was soon picked up by his ladies. He always brings us some little present when he comes, and to-day he brought us a bottle of honey, and some fruit called agra, about the size of a pear, with a hard outer skin, four large black seeds, surrounded by a pleasant acid pulp, like tamarinds, of a cream colour. My servant Pascoe met in the market to-day some Fellatahs, who told him there was no war in Nyffe; that the king was only afraid of the Fellatahs; that the Fellatahs of Raka had taken nine Yourribanis, who had been found in a suspicious place, but were going to return them here on the morrow. Raka is only one day's journey northnorth-east from Katunga.

Monday, 6th.- In the evening, at the request of the king, 1 again set off five rockets, one of which having too low an elevation ran along the ground, but fortunately only set fire to some grass. We afterwards went and saw the king, who, with his ladies and principal men, was sitting outside under the verandah to see the rockets. He presented us with gooro nuts, and said he would come and see us in the morning.

'Tuesday, 7 th. - In the middle of the day the king visited me, and brought a bottle of honey and two cock fowls. He began joking me as to what I was about to give him. I said I had nothing to give him. Says he, "I ask you to give me one of your servants." "I can't do that," says I ; they are free men as well as myself." "What," says he, "no slaves in England!" "No," says I, " as soon as a slave sets his feet in England he is free." "Then," says he, "as you must go, either Mr. Houtson or Richard must stop with me. I must have one." After a good deal of conversation of this kind I asked him to fix a day for our departure. He artfully shifted the subject of conversation to that of women. Would 
I not like a wife? he would give me one. Did he not give us plenty to eat, or did he not use me well? "All very true, and very good," says I, "but I am not like a black man, who has no book to write. I must know the day on which $I$ am to go, as I must have all my books ready for the king of England. Every thing I give away is in that book, every thing I get, and every thing I say." All my talk would not make him fix a day, but he said I should have a servant of his to the king of Youri ; that that road was safe. I would go in four days to Yara in Bamba, which was tributary to him; there I would cross the river Moussa, which ran into the Quorra, three days distance; that the Moussa came from the northwest, and in it were plenty of hippopotami. He is still particularly shy of giving any information about the Quorra, of which, perhaps, he has none. At one time he says it runs into the sea between Jaboo and Benin, and at another that it passes Benin; that the Fellatahs are in possession of Raka, cnly a day's journey northnorth-east, and of all the country between it and the Quorra: he therefore cannot contrive to get me thither. He now shifted the subject of conversation; told me he did not know how many wives, or how many children he had got, but he was sure that his wives alone, hand to hand, would reach from hence to Jannah. He sent for one of his daughters, whom he had given as wife to Abaco, the messenger. His daughters are allowed to take any one they may choose, either as a husband or lover; but it is death to touch any of the king's wives. 'The son, at the father's death, takes all the widows to maintain. 'The king had his skin rubbed over with the powder of a species of red wood, ground very fine, and made like a paste ; it is used by all classes. The wood is brought from Waree and Benin. We gave him a flask of rum on his leaving us, and he promised to give me some of the blue stone of which his beads are made. He says it comes from a country between this and Benin. 'They are not glass, as I at first supposed. 
Thursday, 9th.-This evening I had to take the eunuch to task about our provisions : he had been dealing us out too small a share, and pocketing the rest. He pretended to be in a great rage, and even the milk is now bad.

Friday, 10th.-Moderate breezes and clear. A number of caboceers from distant provinces arrived to-day, and we had nothing but drumming, and whistling, the whole day. The king sent us an invitation to see them, and we went in the afternoon. We found the king seated in an old easy chair covered with crimson damask. 'The caboceers at some distance in front, facing him, dressed in leopard skin robes, their heads well dusted, and also their cheeks, by rubbing their faces in the dust while making their prostrations. It is the court etiquette here to appear in a loose cloth, tied under one arm; part over the other shoulder, and hanging down to the feet in a graceful manner: but no tobes, no beads, no coral, or grandeur of any kind, must appear but on the king alone. 'The cane I made him a present of holds, on all occasions, a conspicuous place: when he walks, he carries it, and when he sits, it is stuck in the ground at some distance before him. He presented us with gooro nuts, and asked me to fire off some rockets to-night.

'The caboceers from the country were attended by their bowmen. They are required to wait upon, and first to prostrate themselves before, the chief eunuch, with dust on their heads. When any one speaks to the king, he must do it stretched at full length on the ground, and it must be said to him through the eunuch, who is also prostrated by his side. When equals meet, they kneel on one knee; women kneel on both knees, the elbows resting on the ground.

Saturday, 11 th.- More caboceers arrive to-day, attended by their wild-looking followers, armed with swords, bows, and arrows; they also, covered with dust and sweat, went through their prostrations before the fat eunuch; the attendants dancing in a circle, while occasionally one came out, and danced a movement in the minuet 
style; in doing which, he would frequently throw a somerset equally as expert as old Grimaldi himself in his best times. I sat for an hour and a half, during all which time the prostrations were continued without intermission, accompanied with the dancing and tumbling, without regard to the intense heat of the sun. I conchaled that they were practising before the eunuch, in order to be perfect when they appeared before the king. They were dressed in leopard skin robes, hung round with tassels and chains. At last the prostrations were completed, and the eunuch sent for several jars of palm wine. 'The caboceers were admitted to drink theirs in the eunuch's house, but the attendants drank their share under a tree. In the afternoon, the king sent for us to see him, but I was too unwell to go, and desired Mr. Houtson and Richard to attend him.

Monday, 13th.- 'This morning, our friend and guardian, the fat cunuch, was drunk; when in that state, he begs every thing he sees. He got Mr. Houtson and myself into his house to see him dance; but independent of his want of steadiness, he was the nost clumsy and unwieldy performer I ever saw. He begged we would also dine with him, but I complained of illness, and Houtson ran off. He followed and made Mr. Houtson hand out the flask, which, withont waiting for a glass, he put to his mouth, and drank upwards of a pint of raw rum, without drawing his breath. He said, he had drank two quarts to-day already, and given away a small cask : that rum was good, and made him fat.

The people of Katunga are fond of ornamenting their doors, and the posts which support their verandahs, with carvings; and they have also statues or figures of men and women, standing in their court yards. The figures carved on their posts and doors are various; but principally of the boa snake, with a hog or antelope in his mouth; frequently men taking slaves, and sometimes a man on horseback leading slaves. 
Their manner of burying the dead is to dig a deep narrow hole, into which the corpse is put in a sitting posture, the elbows between the two knees: a poor person is buried without any ceremony; a rich man has guns fired, and rum drank over his grave, and in his house by his friends and retainers. When a king of Yourriba dies, the caboceer of Jannah, three other head caboceers, four women, and a great many favourite slaves and others, are obliged to swallow poison, given by fetishmell, in a parrot's egg: should this not take effect, the person is provided with a rope to hang himself in his own house. No public sacrifices are used, at least no human sacrifices, and no one was allowed to die at the death of the last king, as he did not die a natural death; having been murdered by one of his own sons: not the present king. Wives are bought; and according to the circumstances of the bridegroom, so is the price. Three days after the bargain, he and his friends go and bring the wife to his own house, when the pitto, or country beer, is sent about freely amongst the guests.

In the afternoon we waired on the king. There is a pleasant walk through a large enclosed park at the foot of the hills, between the house of the king and that of his wives, enclosed by a clay wall. Some parts of the park are planted with corn, yams, \&c. and others studded with beautiful shady trees. The king was sitting under' the shade of one of the trees. I observed to him that I had been here twenty-four days, and was anxious to go on my journey, as the rains were about to set in. He asked if all the white men were going. I said "Only myself and my servants." As I knew him to be skilful in evasive answers, and always to have one ready at hand, I said "Fix a day." His reply was, "Every one would say, the white man came to see the king of Yourriba, and brought him large presents, and requested him to give them a good passage to where they wanted to go; he gave them a bad path; they were robbed 
and killed : all people would say that the king of Yourriba did not do good to white man." He had been busy these last four days with his people, but he had sent a messenger to get a good path. I asked him positively to fix a day, as I could not put off any longer. After consulting with his people, he said, "Nine days." I said, "Well-I shall remain nine days :" without saying one word that I had every thing ready to go.

Foo-foo, the common food of the rich and poor, is of two kinds -white and black: the white is merely boiled yams beaten into a paste with water, and sold in balls of about a pound weight each. 'The black is made as follows:- The yam is first parboiled, then cut into small pieces and exposed to the rays of the sun till quite dry; in this state it is pounded in a large wooden mortar into a flour, and sifted again and again until it is as fine as possible. The flour will keep in this way about six months. When wanted for use, boiling water is poured over it, and stirred round until completely mixed and of a proper thickness; and when so done it is, like the other, made into balls of about a pound weight each. The natives eat it with soup, gravy, or palm oil; or without any other thing.

Wednesday, 15th.-At 3 P.M. we had a messenger from Jannah, who brought letters; one from Captain Clavering of the Redwing, with half a dozen bottles of porter and half a dozen of wine; the other two half dozens having either been broken or drunk on the road. 'The supply was as welcome as unexpected, and proved to us how very little trouble and expense were required to keep up the communication. By the letters of Captain Clavering, it appears that the trunks of the late Captain Pearce and Dr. Morrison had arrived safe.

Thursday, 16th.-Morning cool and cloudy. We had an early visit from the king, who was anxious to have a bottle of our porter, which I could not well refuse. He also begged my looking glass, and one of the tin boxes. In my turn I told him, that since we 
had finished our bullock that he gave us, we had nothing to eat. He replied, we must go to the caboceers. I told him I would do no such thing; that we did not come here to beg. He said I was mistaken; it was not begging; they were all his slaves, and what they possessed belonged to him. I requested, however, that he should send orders to them direct from himself. After a little time he left us: but the eunuch remained; and showing symptoms of sauciness I turned him out of the house.

Friday, 17th.-Morning clear and cool, with fresh harmattan breezes. A great number of people arrived to-day from different parts of the country to pay their annual custom and visit to the king.

Saturday, 18th.-_Morning clear and cold; a strong harmattan still blowing. The religion of the people of Yourriba, as far as I could comprehend it, consists in the worship of one God, to whom they offer sacrifices of horses, cows, sheep, goats, and fowls. At the yearly feast all these animals are sacrificed at the fetish house, in which a little of the blood is spilt on the ground. 'I'he whole of them are then cooked; and the king and all the people, men and women, attending, partake of the meat, which they are said to eat in a state of nakedness, and in company, drinking at the same time copiously of country ale, or pitto; but it is also said, that the least attempt at indecency would be punished with death.

It is stated, moreover, that it depends on the will of the fetish man or priest whether a human being, or a cow, or other animal is to be sacrificed. If a human being, it is always a criminal, and only one. The usual spot where the feast takes place is in a large open field before the king's house, under wide spreading trees, where there are two or three fetish houses. This account I had from a native of Bornou, a Mahometan, and a slave to the caboceer of Jannah.

Monday, 20th._The morning cool. The harmattan still conH 2 
tinues blowing. Our supply of provisions has of late been rather scanty, owing to the avarice of the fat eunuch, our guardian, who pockets as much as he can out of what the king sends us. I have threatened him two or three times, but I believe he trusts to my patient and easy disposition. Complaining to the king would get him a beating, though he is a favourite, and an useful person, wellskilled as a war-captain, and guardian of the king's women.

Tuesday, 21st._Cool and clear. Harmattan continues. A number of caboceers of the different towns came in to-day with their forces, and the king sent for us to come and see them. We went accordingly, and saw about twenty of these dependents, in all their dirt and debasement, who vied with each other which could have most dust, and who could kiss the ground with the greatest fervour. They were stretched at full length on their bare bellies ; no cloth being allowed on this occasion over the shoulder, the body being required to be bare as far as the waist. Old Pascoe calls them the sand-eaters. After our usual compliments to the king, and shaking hands with the caboceers of Eyeo and the sand-eaters, we returned; the king promising to visit us at our house.

At 4 P.M. he came, attended by his women and our fat guardian. The women he left outside, except two; one of whon attends upon him on all occasions bearing a handsome carved gourd, having a small hole covered with a clean white cloth, to hold his Majesty's spittle, when he is inclined to throw it away; the other with a white pot, used with us as a chamber utensil, containing his gooro nuts, since he made me a present of his black ebony box, carved in the shape of a tortoise, which he used for that purpose. After an end had been put to our complimentary inquiries after his majesty's good health, I observed that the time was now come, within a few days only, that he had appointed for my departure. He said, that the messenger he had sent to Youri was returned; that the road was perfectly safe; that he would have me passed from one king 
to another; but that by the way of Nyffe he would not ensure my safety; and that if he suffered me to go where there was danger, it would cause a reflection on him. I thanked him for his lindness, and said that whatever he did was right. He then said that his messenger, and that of the caboceer of Yarro, would attend me to Youri. I thought this a proper time to hint a gentle complaint against our fat guardian, for having for some time past appropriated our provisions to his own use. The old rogue swore through thick and thin that he had given us every thing, even some goats which I had actually purchased at the market, but which he swore he had supplied himself. I told the king it was of no use talking against a rogue like his eunuch, therefore I should hold my tongue. As the king never comes to us empty-handed, he brought us a Muscovy duck, and a bag of rice; the last a scarce article, and not to be had in the market.

Wednesday, 22d.-Cold morning. Harmattan still continues. More caboceers came in yesterday, with their attendants. They waited on us this morning, and we observed that they were well provided with dust, as they had been to wait on the king early; it being the etiquette of Yourriba to hold a levee twice a-day, at six in the morning, and at two in the afternoon.

It is the custom, during the time that the caboceers from the different towns remain on their visit to the king, to act plays or pantomimes, or whatever they may be called. I shall attempt a description of the one I saw to-day. 'The place chosen for this pastime is the king's park, fronting the principal door where his majesty usually sits. A fetish house occupies the left side; to the south are two very romantic and large blocks of granite, by the side of which is an old withered tree. On the east are some beautiful shady trees; and on the north his majesty's house, from whence he views the scene. In the centre are two beautiful clumps of trees; in one of which is a tall fan-palm, overlooking the whole 
area, a space that may include some seven or eight hundred yards square. Under these clumps of trees were seated the actors, dressed in large sacks, covering every part of the body; the head most fantastically decorated with strips of rags, damask silk, and cotton, of as many glaring colours as it was possible. The king's servants attended to keep the peace, and to prevent the crowd from breaking into the square in which the actors were assembled. Musicians also attended with drums, horns, and whistles, which were beaten and blown without intermission.

The first act consisted in dancing and tumbling in sacks, which they performed to admiration, considering they could not see, and had not the free use of their feet and hands. The second act consisted in catching the boa constrictor: first, one of the sack-men came in front and knelt down on his hands and feet; then came out a tall majestic figure, having on a head-dress and masque which baffle all description: it was of a glossy black colour, sometimes like a lion conchant over the crest of a helmet; at another like a black head with a large wig: at every turn he made it changed its appearance. This figure held in its right hand a sword, and by its superior dress and motions appeared to be the director of the scene, for not a word was spoken by the actors. The manager, as I shall call the tall figure, then came up to the man who was lying in the sack; another sack-dancer was brought in his sack, who by a wave of the sword was laid down at the other's head or feet; he having unsown the end of both sacks, the two crawled into one. There was now great waving of the manager's sword; indeed I thought that heads were going to be taken off, as all the actors were assembled round the party lying down; but in a few minutes they all cleared away except the manager, who gave two or three flourishes with his sword, when the representation of the boa constrictor began. The animal put its head out of the bag in which it was contained, attempting to bite the manager; but at a wave of 
the sword it threw its head in another direction to avert the blow; it then began gradually to creep out of the bag, and went through the motions of a snake in a very natural manner, though it appeared to be rather full in the belly; opening and shutting its mouth, which I suspect was the performer's two hands, in the most natural manner imaginable. The length of the creature was spun out to about fourteen feet; and the colour and action were well represented by a covering of painted cloth, imitating that of the boa. After following the manager round the park for some time, and attempting to bite him, which he averted by a wave of the sword, a sign was made for the body of actors to come up; when the manager approaching the tail, made flourishes with his sword as if hacking at that part of the body. The snake gasped, twisted up, and seemed as if in great torture; and when nearly dead, it was shouldered by the masqued actors, still gasping and making attempts to bite, but was carried off in triumph to the fetish house.

'I'he third act consisted of the white devil. The actors having retired to some distance in the back ground, one of them was left in the centre, whose sack falling gradually down, exposed a white head, at which all the crowd gave a shout, that rent tle air ; they appeared indeed to enjoy this sight, as the perfection of the actor's art. 'The whole body was at last cleared of the incumbrance of the sack, when it exhibited the appearance of a human figure cast in white wax, of the middle size, miserably thin, and starved with cold. It frequently went through the motion of taking snuff, and rubbing its hands; when it walked, it was with the most awkward gait, treading as the most tender-footed white man would do in walking bare-footed, for the first time, over new frozen ground. The spectators often appealed to us, as to the excellence of the performance, and entreated I would look and be attentive to what was going on. I pretended to be fully as much pleased with this caricature of a white man as they could be, and certainly 
the actor burlesqued the part to admiration. This being concluded, the performers all retired to the fetish house. Between each act, we had choral songs by the king's women, in which the assembled crowd joined their voices.

The kingdom of Yourriba extends from Puka. on the south, which is within five miles of the sea, to Lagos and Whydah in that line; to the north to about the 10th degree of north latitude. It is bounded by Dahomey to the north-west, which is reckoned a tributary province: Ketto and the Maha countries on the north, Borgoo on the north-east, the Quorra or Niger to the east, Accoura, a province of Benin, on the south-east, five days' journey distant; Jaboo to the south and west. Its tributaries are Dahomey, Alladah, Badagry, and Maha. From the sea coast to Chocho in latitude $8^{\circ} 8^{\prime}$ north, longitude $4^{\circ} 2^{\prime}$ east, the country rises by a gradual ascent; the soil of a strong red clay and mould, and where the woods have not been cleared, they may be considered as impervious. The trees are of great size, with most luxuriant foliage. From Chocho to Koosoo is a range of granite hills, running from west-north-west to east-south-east. These hills are of grey granite, bare of vegetation, and in solid masses. They are from four to eight hundred feet above the level of the valleys, which are narrow, winding, and well cultivated, and watered with innumerable small streams. The soil a thin black mould. From Koossoo to Eyeo, the country is less hilly, the hills in broken irregular ranges, and running principally from north-east to south-west, with here and there detached masses thrown up, as if by some great convulsion of nature. The granite of which they are composed is of a softer kind, and crumbling away with the weather. The valleys between these hills widen into plains, as they advance to the northward. In the hilly region, the trees are thinly scattered, low and stunted. The domestic animals are horses of a very small breed, and even these are scarce; the horned cattle also near the coast are of a small size: 
but as we approach the capital, they are as large as those in England. Many of them have humps on their shoulders, the same as those in Abyssinia and the East Indies. 'They have sheep of the common kind, and also those which are found in other parts of Africa; hogs, Muscovy ducks, fowls, pigeons, and a few turkeys. Of the wild animals, and the feathered race, I can say but little, having seen none of the former except monkeys ; but the natives report that the hyæna and the leopard are very common. The lion, also, is found in some parts of the country ; yams, Indian corn, millet, and challots ; fruits, such as oranges, limes, pears, apples, \&c. are plentiful throughout the kingdom. The cotton plant is cultivated to a considerable extent, and the wool manufactured into cloth. The commerce of this country is almost entirely confined to slaves, though a considerable quantity of cloth is made, and bartered with the people of the coast for rum, tobacco, European cloth, and other articles. The medium of exchange throughout the interior is the cowry shell. A prime slave at Jannal is worth in sterling money, according to the value set on the articles of barter, from three to four pounds.

The government of Yourriba is hereditary, and an absolute despotism, every subject being considered the slave of the king; but its administration is mild and humane, and appears to have been so for a long period. 'The only distinction of rank that obtains is that of caboceer, who may be considered as the governor of a distant town or province; the appointment of these governors depending on the will of the king. The military force consists of the caboceers and their own immediate retainers, which, allowing one hundred and fifty to each, will not give such immense armies as we have sometimes heard stated; that of Yourriba is perhaps as numerous as any of the kingdoms of Africa. I think the general appearance of the Yourribanians has less of the characteristic features of the negro than any other I have yet seen; their lips are less thick, and their noses more inclined to the aquiline shape, than 
negroes in general. The men are well made, and have an independent carriage, that cannot fail to attract attention. The women are almost invariably of a more ordinary appearance than the men, which may arise from their being more exposed to the sun, and the drudgery they are obliged to undergo; all the labour of the land devolving on them.

The city of Eyeo (in Houssa language, Katunga), the capital of Yourriba, is situated in latitude $8^{\circ} 59^{\prime}$ north, longitude $6^{\circ} 12^{\prime}$ east. It is built on the sloping side and round the base of a small range of granite hills, which, as it were, forms the citadel of the town; they are formed of stupendous blocks of gray granite of the softest kind, some of which are seen hanging from the summits, in the most frightful manner, while others, resting on very small bases, appear as if the least touch would send them down into the valley beneath. The soil on which the town is built is formed of clay and gravel, mixed with sand, which has obviously been produced from the crumbling granite. The appearance of these hills is that of a mass of rocks left bare by the tide. A belt of thick wood runs round the walls, which are built of clay, and about twenty feet high, and surrounded by a dry ditch. There are ten gates in the walls, which are about fifteen miles in circumference, of an oval shape, about four miles in diameter one way, and six miles the other, the south end leaning against the rocky hills, and forming an inaccessible barrier in that quarter. The king's houses and those of his women occupy about a square mile, and are on the south side of the hills, having two large parks, one in front, and another facing the north. They are all built of clay, and have thatched roofs, similar to those nearer the coast. The posts supporting the verandahs and the doors of the king's and caboceers' houses are generally carved in bas relief, with figures representing the boa killing an antelope or a hog, or with processions of warriors attended by drummers. The latter are by no means meanly executed, conveying the expression 
and attitude of the principal man in the groupe with a lofty air, and the drummer well pleased with his own music, or rather deafening noise. There are seven different markets, which are held every evening; being generally opened about three or four o'clock. The chief articles exposed for sale are yams, corn, calavances, plantains, and bananas; vegetable butter, seeds of the colycynth, which forms a great article of food, sweetmeats, goats, fowls, sheep, and lambs; and also cloth of the manufacture of the country, and their various implements of agriculture. The price of a small goat is from 1500 to 2000 cowries; a large sheep, 3000 to 5,000 ; a fowl, 150 to 200 ; yams, 4000 per hundred; a horse, 80 to 100,000 ; and a cow from 20 to 30,000 ; a prime slave, 40 to 60,$000 ;-2000$ cowries being equal to one Spanish dollar. Trona, or natron, is brought here from Bornou, and sold to all parts of the coast, where it is much in request, to mix with snuff, and also as a medicine.

Saturday, 25th.-This afternoon we had a visit from the king; he brought with him a duck, some rice, and goora nuts. I told him I was all ready to go, whenever he chose to give me the escort and messengers. He said the caboceers of the different towns through which I had to pass were still here, but as soon as they left I should go. I asked him, as I was writing to England, what he wanted from thence. He said, a brass crown, fine yellow and blue cloth, large coral, some gaudy carpeting, an English drum, and about half a ton of cowries. The whole of this curious catalogue would not cost, as I suppose, more than $£ 200$. I told him, therefore, that I should send the list home.

Sunday, 26th.-Morning dull and hazy, with an oppressive sultry heat, the wind north-north-east; causing the same depression of spirits as the siroc wind in the Mediterranean, and which affected every one of the party, and made us all sigh for a breeze, and to proceed on our journey.

Wednesday, 1st March.-On this day the weather began to clear up, with a fine breeze from the eastward. Our friend the fat eunuch 
is evidently playing the rogue with us, as we neither can get provisions, wood, nor water, but with the greatest difficulty. He sees he has got all I intend to give, either to the king or any body else. A messenger of the caboceer of Jannah went and returned from Rakah to-day, to buy trona. The Yourriba name of Rakah is Saguda: the Quorra is only about two hours' easy walking to the eastward of it. The following day, in the afternoon, I had a visit from the king. I asked him why I was longer detained; said I had waited with patience through the several times he had appointed for my starting, but it appeared I was just as far from getting away as ever. He hesitated, and gave me an evasive answer. I asked him to tell me distinctly. No, he could not do that, as he wished to get me a large horse to ride before I went. I said I would ride a small one. He then said he had only one. I asked him if he would allow me to hire horses from the caboceers. What," le replied, "will they say of me, if I allow you to go away in this way after your king sending me such a present?" He then begged I would stop for three days more, until he could get horses, and I should certainly go. I pointed out to him the number of times he lad broken his word: he said the reason he would not fix a day now was, that he might not break his word again.

Monday, 6th.--It was not before the 6 th that the king paid me another visit, and told me, that the Yarro messengers were ready, and that I might go to-morrow or next day, and that he intended to give me a horse. I thanked him, and told him I was quite ready and determined to set off to-morrow, as delays here were dangerous. Accordingly, the next day, when every thing was ready for starting, I was again visited by the king, who, after giving me in charge of what he called the Yarro messenger, told me that the sultan Yarro would take the greatest care of my baggage, and forward me to the king of Youri. He then made me a present of a horse, for which I thanked him, and took my leave. 


\section{CHAP'TER III.}

JOURNAL OF PROCEEDINGS FROM KATUNGA, OR EYEO, TO BOUSA, ON THE NIGEl, OR QUORRA, THE PLACE WHERE MUNGO PARK PERISHED.

A th three o'clock in the afternoon I set out from Katunga, and passed the gates of the town, with the same escort 1 had on entering it, headed, as before, by the king's brother. In the evening we halted at the village of Assina for the night, where I got two fowls and some yams. The poor people were just returning to their houses, from which they had been driven out by the Fellatas last year, who continue to infest the country, even up to the gates of Katunga.

Wednesday, 8th.-Left the village of Assina; the morning dull, but cool and pleasant; arrived at T'show, where I had breakfast, and left it at $10 \mathrm{~A} . \mathrm{M}$., and after travelling over very bad roads, cut up and crossed by deep rocky ravines, reached the higher ground, which was well cultivated; but their villages appeared to be all in ruins, which my guides told me were destroyed last year by the Fellatas. At noon arrived at the town of Algi, which is now rising from its ruins; it having shared the same fate as the villages I had passed. The inhabitants are now returning to their ruined dwellings, some of which they have already repaired; they said they had nothing but a little grain, and a few yams for seed; of these they gave me part, and the best house in the town. The Yarro messenger had not made his appearance, and I now learned, that Algi 
no longer belonged to the king of Yourriba, but to Yarro, the chief or sultan of Kiama, a petty state of the kingdom of Borgoo; that Kiama was the name of the province, and Yarro the name of the sultan, as he is called. I gave the king of Yourriba's brother, who commanded the escort, a fatlom of red cloth, and ten coral beads, as he is to return to Katunga as soon as he has seen me off from this place.

'Thursday, 9th. - Light airs, and clear. I was unable to get off today, as they could not collect the people to carry my baggage. The king of Yourriba's brother declared, that he or his people had had nothing to eat all night, or since lıe had left $A$ ssina; yet lie got the caboceer of the place to send me a pig, for which I gave five coral beads: the man said he was ashamed to see me, as he had nothing to give. Algi consists of three walled villages, and before it was burnt down had been of considerable size: they pointed out a rock close to the soutl side of the town, from whence the Fellatas flew the pigeons to set fire to it. The mode of doing it was, by making combustibles fast to the tails of the birds, which, on being let loose from the hand, immediately flew to the tops of the thatched houses, while the Fellatas kept up a sharp fire of arrows, to prevent the inhabitants extinguishing the flames. There are still a number of Fellatas in this neighbourhood, who are nearly white, but pagans: they speak the Fellata language, and agree in every thing but their religion.

Friday, 10th._-This morning the king's brother accompanied me outside the town. I sent by him a letter to Mr. Houtson, to tell the king of Yourriba he had behaved very ill in not sending a proper messenger; that the one he had sent was not the Kiama messenger, but the butcher's son of Algi, and that in no one point had he performed his promise to me. We halted at the village of Watatoo, where I was lodged in one of the best houses; this village had also shared the fate of Algi, having been burnt down by the Fellatas, and the inhabitants were just returning to their homes. 
The country between Watatoo and Algi is cultivated in a number of places, and planted with cotton, yams, and maize, and is diversified by hill and dale: the hills are low and rocky; the rocks of a fine-grained sand-stone. In the evening the head man of the village made me a present of four fowls and some yams.

Saturday, 11th.-Cool and cloudy; during the night, heavy storm of wind, with thunder and lightning. At daylight I had every thing ready for starting; the butcher's son having arrived last night, mounted on a little mare, with a saddle, and he without shoes or boots. On leaving Watatoo, I gave the two head men of the village a fathom of blue cloth each, as they had been as good as their circumstances would admit, and they promised to send every thing after me as soon as possible. In about fifteen minutes after leaving Watatoo, I arrived at and crossed the river Moussa, which formerly divided the kingdoms of Yourriba, and Borgoo: it was dry in a great many places, with a very rocky bed; when full, about thirty yards in breadth; and runs apparently with a very strong current. 'They say, it is the same river I passed on the road to T'show, on the north side of the hills, and enters the Quorra opposite Nyffee, and near Rakah. After crossing, I travelled through thick woods for an hour, when I halted at a few huts on the north side of the river, called Bori, until the baggage should arrive. A hut stood apart from the rest, near the banks of the river; the grass and weeds carefully cleared away from around it. The messenger and people who were with me went one after another to say their prayers; which they did, by lying down, with their foreheads towards the door, which was secured by a mat: they appeared to be very devout, and having finished their prayers, slipped a few cowries inside the mat. I asked if I might go and look in, but they would not allow me. I asked them who they prayed to: they said, to the God that gave them plenty of water, corn, and yams. They say there are great numbers of hippopotami and 
crocodiles in the river during the time that it is full. The carriers, with the baggage, came up very slowly, and the heaviest loads were mostly carried by old women; and I could not help noticing the cold-blooded indifference of the young men, who would not give the poor old creatures the least assistance: however, I made them carry the heaviest loads, to the great joy of the old ladies. During the time I was waiting for the carriers to come up, a piece of cloth was stolen from one of the women. The bearers flew to arms instantly, the arrows laid on the strings, and the bows bent. I expected nothing but a battle; but fortunately the thief was discovered to be one of the villagers, who had pretended to be asleep, and drunk, all the time we were here; he had stowed the cloth under the thatch of the house, and I never saw a woman more overjoyed in my life than the poor honest creature was, when she recovered her cloth; she came and knecled down to thank me, as she said it was by my influence the cloth was returned. On the tops of the huts, which are of the real Bornou coozie form, the first I have seen since I came to Africa this time, were stuck a number of crocodiles' eggs, which are considered as a protection against that animal. All the baggage having now arrived, I left the village of Boru, with its shady trees and mud temple, at a very quick pace, over a flat country apparently not far from the river Quorra, thickly wooded with fine tall trees, and inhabited by large antelopes, numerous traces of which I saw. In the evening halted in the wood, close to a small stream of water.

The next morning, on leaving our encampment, a messenger from the chicf of Kiama arrived; he had been sent to see if I was on the road, and to return with speed and inform his master. Our road was through thick woods; the soil a red clay, mixed with gravel. At $10 \mathrm{~A}$. M. halted at the town of Oblah, which has been walled, and of considerable size, but now only a few huts remain, the rest having been burned by Yarro. Here my servant Richard 
was taken very ill, and unable to ride; in consequence of which I remained until the afternoon, when he got better, and was able to proceed, by a man liolding him on the bare back of the horse, for we had no saddles. Halted at the village of Socka, where I got one of the best huts, a few yams, and four fowls.

Monday, 13th.-Morning cool and cloudy. At daylight an escort arrived from the chief of Kiama, mounted on as fine horses as I ever saw. One man had on a white cotton tobe, or shirt, written over entirely with Arab charms, which made it look like printed cotton at a distance. 'They were a despicable, lawless set of fellows; for as soon as they had delivered their master's compliments to me, they began to plunder the village of the goats and fowls. One fellow rode in at full gallop, through the fence of matting which surround the huts, brandishing his spear; those on foot following him, and making a prize of every thing they could lay their hands on. I gave the head man of the village, out of sight of the escort, a fathom of blue cloth, and two knives. On leaving Sacko, I was now accompanied by this escort, who formed as fine and wild a looking troop as I ever saw. 'They had brought me a saddle, but Richard and Pascoe rode bare-backed, and our little Yourriba mares made a miserable contrast with the gallant looking troop who were guarding us: but I consoled myself with the thought that I had not plundered the village. Our road lay through a country rough and uneven, consisting of hill and dale, with rocks of quartz and sandstone, a range of lills closing round to the right. Passed two villages, at which my honest escort levied a tribute of goats and fowls. At nine A.M. we arrived at the city of Kiama, and rode instantly up to the house of the chief; where, after waiting under the shade of a wide spreading tree for a few minutes, I paid my respects to the chief, or sultan, as they call him : his name is Yarro. He was sitting in the porch of his door, a stout, good looking man, past the middle age, dressed in a white tobe or large shirt, with a 
red Moorish cap on his head. We shook hands; and after telling him who I was, and where I wished to go, he said, Very well, I had better go and rest from the fatigues of my journey, in the house that was prepared for me; and sent his head man to conduct me to it. He was attended by a mob of people, who were lying on their bellies and their sides, talking to him in this posture. After taking my leave, I went with his head man to my house, which proved to be a very good one. It consisted of three large huts inside a square, in one of which I put the baggage; occupied the second myself; and the servants the other. I had not remained long, before Yarro sent me a present of milk, eggs, bananas, fried cheese, curds, and foo-foo; and I was left alone until the heat of the day was over, when I received a visit from Yarro himself. He came mounted on a beautiful red roan, attended by a number of armed men, on horseback and on foot; and six young female slaves, naked as they were born, except a stripe of narrow white cloth tied round their heads, about six inches of the ends flying out behind; each carrying a light spear in the right hand. He was dressed in a red silk damask tobe, and booted. He dismounted, and came into my house, attended by the six girls, who laid down their spears, and put a blue cloth round their waists before they entered the door. After he was seated, he began by asking after the health of the king of Yourriba, who, I said, I had left very well. I then told him I had been sent by the king of England to visit Bornou; that I was the king of England's servant, and hoped he would assist me in proceeding on my journey; and that $I$ intended to make him a suitable present; that I wanted thirty-six men to carry my baggage, and two horses for my servants to ride; and that I wished to stay as short a time as possible, as the rains were near at hand, which, if overtaken by them, would prevent my travelling; that the season of the rains was very sickly, and fatal to white men; that three of the white men who had left England with me had 
died in Yourriba, and it was more than probable that I should die also, if exposed in any of these countries to the rains. He said I was going to stay but a short time, and that he would send me to Wawa; from thence I should be forwarded to Boussa; then to cross the river Quorra to Injaskee, and thence to Bornou. On his leaving me, I attended him to the door. He mounted his horse, the young ladies undressed, and away went the most extraordinary cavalcade I ever saw in my life.

After sunset I had a visit from the taya or chief of the caravan belonging to Houssa, which had arrived yesterday from Gonja and Ashantee, and a trader of Bornou who had known me when I was in that country. 'They advised me by all means to leave this country as soon as possible, as they were all kaffirs; that they would plunder me of every thing I had; and that on no account ought I to go by the way of Youri, as they were now at war with the Fellatas, and the road entirely shut up; that, besides, the road by Youri was the most distant; and that I must urge this chief to send me away as soon as possible.

Tuesday, 14th._This morning I waited on Yarro with my present, which consisted of the following articles:- a large blue silk umbrella, one of 'Tatham's African swords, three fathoms of blue cloth, three fathoms of red, some red beads and coral, an imitation gold chain, two bottles of rum, two phosphorus boxes, four knives, and six pair of scissars, and some prints. The cloth I had spread out at full length : the large mock coral beads he shook at the naked young females, as much as to say, Which of you will get these? On seeing the sword he could not restrain his delight, and drawing it, and brandishing it around his head, he called out, "I $\mathrm{F}$ baturi! Ya baturi!" "Oh, my white lord! Oh, my white lord!" $\mathrm{He}$ was certainly more pleased than any man I ever saw with a present; his eyes sparkled with joy, and he shook me about a dozen times by the hand. I pressed the necessity of my departure, which he 
said should be the day after to-morrow. I then took my leave; and a short time after returning to my house he sent me some milk and a sheep; and in the afternoon, by his head man, Abubecker, an earthenware jug to look at: it was of English earthenware, representing old Toby Philpot with a flowing jug of ale in his hand. I have seen more European articles, such as earthenware jugs, brass and pewter dishes, pieces of woollen and cotton cloth, within these two days that I have been in Kiama, than I saw during the whole time I was in Yourriba.

In the evening I had a visit from the head man of the Houssa goffle, or caravan, which is on its way from Gonja and Ashantee: they consist of upwards of 1000 men and women, and as many beasts of burthen. He offers to carry all my things to Kano for a certain sum. He says that they had been detained in Gonja a long time, twelve months, on account of the wars; that the king of Ashantee was dead, as also the heir, and that the Ashantees were now without a king. This taya, as the head man of the goffle is called, is named Abdullah, a native of Kano. I heard a great many inquiries made after myself, they not knowing me in my English dress, and without a beard. They talk to me about having seen me in Bornou and Soudan: I do not yet tell them that I am the same person.

The principal part of the cargo of these Houssa merchants consists in gora or kolla nuts, which they receive in exchange for natron, red glass beads, and a few slaves, principally refractory ones which they cannot manage. They carry their goods on bullocks, mules, asses, and a number of female slaves are loaded; even some women hire themselves to carry loads to and from Nyffé. Some of the merchants have no more property than they can carry on their own heads. The duty they pay to the chief of Kiama is ten kolla for each load.

Wednesday, 15th.-I early visited the chief this morning, to urge my departure. He was surrounded by a number of his head men; 
and when I had finished my story, he made a number of objections to my going off to-morrow. One of his fellows said I had given nothing to be allowed to go. I said I was not a merchant, possessed of a great quantity of goods to give away; that I had only a few things to give to the different sultans on the road, to afford me protection to and from Bornou, and pointed out to Yarro each separate place where I should be obliged to give. He said that, before I left Kiama, I must give a present to his governor and the head men of the town, whom he would send to me. I told him, if this was to be the way, I should very soon have nothing to give: that at Wawa, Boussa, and Injaskie, they would be sure to hear what I had given here, and that they would expect the same. He then said, that as soon as his messenger arrived from Katunga, who was a very trusty man, I should go to Wawa. I informed him that the chief of the Houssa caravan had offered to take me to Kano from Wawa, and that he would carry every thing for me. "Oh," says he, "you must not believe these stories; he would take you a day or two on the road, and then leave you : where is he to get the means to carry your things? and besides, he has not paid his custom yet, and until that is paid he cannot go: you shall go to-morrow or next day." On which I thanked him, and took my leave. On my return I had a messenger from his principal wife, to say she wished to see me: and she sent me five yams and a fowl.

In the afternoon I went to visit her sable majesty. I first repaired to Yarro's house, where, after some conversation about my going away, I told him I wished to send a letter to Badagry, and if he wanted a tea-pot like mine I should send for one for him : he said yes, he wanted a tea-pot and a pair of gold bracelets, and some other things, which he would mention to me by and by. His wife and daughter came in: the first old and ugly; the next about twenty-five years old, which is past the meridian in this country. After paying their respects to Yarro, which is after the Yourriba 
fashion, I gave them one fathom of red cloth, one fathom of blue, some scissars, needles, beads, and silk. Yarro asked me if I would take his daughter for a wife; I said "Yes," after a great many thanks for my present. The old woman went out, and I followed with the king's head man, Abubecker. I went to the house of the daughter, which consists of several coozies separate from those of the father, and I was shown into a very clean one: a mat was spread: I sat down; and the lady coming in and kneeling down, I asked her if she would live in my house, or I should come and live with her: she said, whatever way I wished: very well, I said, I would come and live with her, as she had the best house. She kept her kneeling posture all the time I was in the house. I took leave of her, and went home, when one of the great men mentioned by Yarro waited upon me, and I gave him a present of two knives, some beads, and a yard of cloth.

'Thursday, 16th.-The king's son came to-day for my advice : a fat, gross, tall man. He said, on my inquiring after his disorder, that every month he had a great throbbing of blood in his head, attended with pain; that he lost the use of his limbs, and could not stand; that the pain then fell down to his breast, and remained altogether four days, coming on always a few days before the new moon. I weighed him out nine doses of calomel, of seven grains each, desiring him to take them one at a time when the throbbing came on, and if he could get bled in the head to have that done also; and, with the assistance of God, I hoped he would get well before he had taken the nine doses. I had a visit also from the princess, for the purpose of receiving a small donation of beads. She would not sit down on the carpet or mat, as her father had sat on it when he had been in my house. Such is the custom: a daughter must not presume to sit where her father has sat. A wife of the governor of the town also came to see me. She brought me a present of some cowries, as she said her father had been a servant 
to white men : she would sleep well and happy to-night, as the joy or wish of her life was accomplished-she had seen me.

I had a present of a sheep, four fowls, and some yams, from a young man related to Yarro, for my advice and assistance; as I now intend my advice in the medical way shall turn to some account: without that I should never have a moment's peace for patients. This young man had nothing the matter with him: he was only afraid he was going to get the disorder his mother died of, which he described as follows:-First, swellings of the eyes and ears, then contracting of the toes and fingers; the skin on the body peeling off, and the flesh looking red and raw; then death. I gave him twelve papers of calomel, of two grains each, desiring him to take one every morning, besides giving him a strong dose of Croton oil (three drops), and a dose of Seidlitz to wash it down.

Every night we have dancing and singing. Their music is the Bornou flute, the Arab fiddle, and the drum. There appears not the least jealousy to exist in Kiama: men's wives and maidens all join in the song and dance; even those of the Moorish belief seem to forget that part of their creed in Kiama.

Friday, 17th.-This being jama, or the day Mahometans attend the mosque, kept by them as we keep our Sunday, the pagans also take advantage of the day, and spend it in showing their fine clothes, and paying and receiving visits. I had a visit from the governor, who came in state: he was attended by a great rabble, and two drums: he had on a turban over a European foraging cap, two or three tobes of Manchester cotton; the rest of his dress was of country-made cloth. After the governor left me I visited Yarro with a present of six wax candles, and the remains of my red beads of the largest size, as he says his women are very fond of them; and this is to be my last present, as I am to go away to-morrow. He says he will give me carriers; lend me horses; and, as I will have to sleep in the woods, he would send plenty of provisions : his 
people should sleep on one side the baggage, and mine on the other, at night; and then, when every thing went safe, I could not but say Yarro was a good man.

After the heat of the day was over, Yarro came, attended by all his train. The most extraordinary persons in it were himself and the bearers of his spears, which, as before, were six naked young girls, from fifteen to seventeen years of age. 'The only thing they wore was a white bandeau, or fillet of white cloth, round the forehead, about six inches of the ends flying behind, and a string of beads round their waists; in their right hands they carried three light spears each. Their light form, the vivacity of their eyes, and the ease with which they appeared to fly over the ground, made them appear something more than mortal as they flew alongside of his horse, when he was galloping, and making his horse curvet and bound. A man with an immense bundle of spears remained behind at a little distance, apparently to serve as a magazine for the girls to be supplied from, when their master had expended those they carried in their hands.

Yarro is a stout, good-looking man, with large eyes, a handsome Roman nose, a short grisly beard, sits well on horseback, and was dressed in a high red Moorish cap, a tobe or large shirt, boots, and brass stirrup-irons. His horse's neck was bedecked with small brass bells and charms, and was as fine a dark bay as I ever saw. The rest of his attendants were not worth mentioning: some on horseback, some on foot; and one only had an old musket, which missed fire every time they snapped it. The whole of the horse in attendance might be about fifty, who filed past my door, and then halted, when Yarro alighted and came in. I had tea prepared for him, which he professed to like very much; but he would not drink milk with his tea, as it is forbidden by his fetish. The girls came into the house with him, but a cloth for the waist was first given them to put on. After tea he returned, and at his request I went 
to the front of his house, where there was some by no means bad horse-racing, in an oblong square in front of his house, formed on one side by tall shady trees, the end closed by the rocky ridge. The horses ran in pairs up this square, sometimes a large Bornou horse paired with the small native breed, the latter of which appeared to dispute the victory often with the larger horses of Bornou. Towards the close, young boys rode on bare backed young horses, which was not the worst of the sport. After the racing I went and complimented Yarro on his riding, as he also was one of the racers, and of course won.

Kiama, the principal city of a province of that name in the kingdom of Borgoo, is situated in latitude $9^{\circ} 37^{\prime} 33^{\prime \prime}$ north, and longitude $5^{\circ} 22^{\prime} 56^{\prime \prime}$ east of Greenwich. It is governed by a chief whose name, Yarro, signifies The Boy; and both city and province are, as frequently happens in Africa, sometimes called after him. The province is thinly inhabited, and the city straggling and ill built. The houses consist of circular huts, or coozies, built of clay and thatched : a number of these, enclosed in a square fence of matting, generally form but one house. The city is built on the south side of a rocky ridge, and is surrounded by an extensive low clay wall, which is broken down in a number of places: inside the walls are plantations of corn and yams. The surrounding country is thickly wooded, with but few plantations, and the country is said to abound in game of all descriptions.

Kiama is one of the towns through which the caravan from Houssa and Bornou passes to and from Gonja, on the borders of Ashantee: it also has a direct trade with Dahomey, Youri, Nyffé, and Yourriba. There is no fixed duty for the merchants to pay, but the chief takes just as much as can be squeezed from them. 'The inhabitants are pagans of an easy faith; never praying but when they are sick, or want something, and cursing their object of worship 
as fancy serves. 'The Houssa slaves amongst them are Mahometans, and are allowed to worship in their own way.

The town (and I think I speak within bounds) may contain 30,000 inhabitants. They are looked upon by all who know them as the greatest thieves and robbers in all Africa ; and it is enough to call a man a native of Borgoo, to designate him as a thief and a murderer. Their government is despotic; and it appears very little protection is given to the subject, as one town will plunder another whenever an opportunity offers. Their manner of salutation to superiors is by prostration at full length on the ground, but without throwing dust on the head or body: the women kneel on their knees and elbows, holding the two open hands turned up towards the face. 'They say that a country called Gourma lies eight days' journey to the north of them; Gonja is to the W.N.W.; and that a small territory called Katakolee lies between Gonja and Borgoo. They sell in the market Brazil tobacco, snuff, natron, yams, plantains, bananas, milk, vegetable butter, gora nuts, and honey in great plenty and cheap. Sheep and bullocks are abundant: the latter mostly in the hands of the Fellatas, who inhabit the woods, shifting about from place to place as pasture is good. 'The Borgoo people will not suffer them to carry any weapons of defence. Their best horses they get from the Bornou and Houssa merchants, who bring them for sale.

On the 18tl, after breakfast, being provided with carriers and two horses, one saddled for myself, I took leave of Yarro, and left Kiama. The Houssa caravan left before me, but was to halt at another village, at a little distance from my route. 'The road was principally through thick woods, with a few plantations of yams, near some villages that we passed, inhabited by Fellatas. One deserted village, they said, had been abandoned last rainy season, on account of sickness; but what the disease was, I could not learn. The in- 
habitants of these villages were mostly Fellatas, who take care of Yarro's cattle. The road very winding, diversified by gentle hill and dale; the soil red clay and gravel, with rocks and stones here and there, of a gritty sandstone, with large square pebbles of quartz. At 11.40 A. M. halted at the village of Bonaga, where I got a good house; and I found Yarro had sent forward two goats and a large quantity of yams, which I shared out to the carriers of the baggage. The day was excessively hot, and it was late before all the baggage came up. The head man of the village sent me three large bowls of foo-foo, with goats' flesh dressed in the skin, which is the saving way of this country, nothing being thrown away but the hoofs and horns. Just as I was going to bed in the evening, Abubecker, who by Yarro's order had accompanied me, to see me safe on my journey, came running into my room in his shirt, apparently in a great fright, and said the men had run away who were engaged to carry the baggage, and he must ride into the town to bring them back. I thanked him, and said I hoped he would make haste. He waited a little; and I suspected he wanted to draw a present out of me, though I had given him more than any other person in Kiama except Yarro.

Sunday, 19th.-At daybreak I had every thing ready for starting, but the manouvring of old Abubecker kept me until 7. 30 A.M. ; and even then I had to give three yards of blue cloth and several strings of beads before I could get the baggage off. After starting, our road was through a thickly wooded country of fine tall trees, with little underwood, the country rising into gentle hill and dale, and the path very winding. At 10 we fell in with the Houssa caravans. They occupied a long line of march : bullocks, asses, horses, women, and men, to the amount of a thousand, all in a line, after one another, forming a very curious sight; a motley groupe, from the nearly naked girls and men carrying loads, to the ridiculously and gaudily dressed Gonja traders, riding on horseback, some of these 
animals being lame, and going with a halt, and all in very bad condition. The poor girls, their slaves, are compelled to travel with a heavy load on their heads, yet are as cheerful and good-natured as if they were at home grinding corn in their own native country. The road lay over a level plain covered with trees; the soil a red clay, with gravel and ore, among rocks of clay ironstone, appearing, from the softer parts, to have been washed or worn away, as if it had undergone the action of fire. We halted near to a small rainyseason stream, in which were pools of water. Here and there saw numerous traces of the large antelopes, buffaloes, and elephants. The latter, they say, the natives do not kill, because they can get plenty of other meat, and they can prevail on no one to buy the tusks. They destroy wild animals with poisoned arrows, one of which they pretend to say will kill an elephant in about an hour. They eat the flesh of the animal slain with these arrows, but cut out and throw away the piece around the poisoned wound. Yarro's messenger has promised to show me the tree from which they get the poison when we arrive at Wawa: they tell a number of extravagant stories about its power and effects, which are too ridiculous to believe.

In the evening I went to the place where the Houssa people were encamped, in order to conclude my bargain with the taya, or head man of the caravan, and to make him sign the written agreement in Arabic by which he was to be bound to carry my baggage and presents from Boussa to Kano; and for which I was to pay him, the day after my arrival at the latter place, two hundred thousand cowries. He had always fought off the agreement, saying, I could conclude the bargain when I got over the river; that I must get the sultan of Boussa to allow me to go, and then we should conclude the bargain. I never could get him to say how much he would take them for, or even that he would take them at all. I now said he must determine, as, before I knew whether he would for certain 
take them or not, it would be of no use asking the sultan of Boussa; ' for if I get the sultan's leave, and you get me on the road, you may charge what you please: if he does not allow me to go, signing the agreement will do no harm, it will only be the loss of the papers. You are mistaken if you think I have any thing to fear from the sultan of Youri ; I am a servant of the king of England, and will receive assistance and protection whichever route I take." He said he would send for his partner. His partner came, Malem Mohamed, or the learned Mohamed; a man that could not read or write, but could repeat a chapter or two of the Koran by heart. He was a palavering old rogue, who always repeated, to whatever the taya said, the words " madealla, madealla,"- " very good, very good,"without giving any answer to what I asked. I told them, it did not require much consideration about the matter: this must be done, yes or no, before I see the sultan of Boussa; for if they did not determine whether they would take my things or not, I would go direct to Youri. The taya then said, how many loads would I have? I said, fifteen bullocks or asses; that I would pay him at Kano, the day after my arrival, as I could have what money I wanted from Hadji Hat Saleh on giving him a receipt, as I had no money here; (not wishing to let them know that I had a dollar here, as it might endanger my existence and that of all my property). "Well," says he, "I know you can have what money you want from the merchants of Kano: I and my partner will consider of the affair to-night, and give you an answer to-morrow." The taya returned with me to my encampment, and, to my surprise, told me that I must not let it be known that I was going to the Fellatas: "Say you are going to Bornou." "So I am," I said ; "I have got a letter for the sheikh, which I will show you to-norrow." When the taya left me, I began to think that what Yarro of Kiama had told me was true. When I asked him to go with the caravan, says he, "Are you a merchant? if you are, go with the caravan: if you are the king of England's messenger, you have nothing to do with them ; 
your way is to go from one king to another, not with caravans of merchants. You will find plenty of people to put evil in your head; if you are wise, do not believe them."

Monday 20th.-At 6 A. M. left our encampment. Our road through a woody country, rising into hill and dale, with some beautiful rocky mounts, perched on the heights composed of blocks of sandstone and clay ironstone; the soil a red clay and gravel. We halted at the village of Barakina, where I stopped until the carriers came up. As I arrived at this village, a hunter came in from the chase. He had a leopard's skin over his shoulder, a light spear in his hand, and his bow and arrows slung over his shoulder. He was followed by three cream-coloured dogs, a breed as if between the greyhound and cur: they were adorned with round collars of different coloured leather. The hunter and his dogs marched through the village as independently as ever I saw a man, without taking the least notice of us, or even looking at us. He was followed by a slave carrying a dead antelope that he had killed this morning. They say the people of Borgoo are the greatest hunters in Africa, and that the people of this village and of those we have passed live entirely by the chase; the little ground they cultivate being worked by the women.

Leaving Barakina, and travelling until noon, I came to a rocky ledge, formed like a wall, in some places rising into beautiful rocky mounts with bold precipices, shaded on the top with trees of the most luxuriant foliage. 'The road lay through a narrow pass in the ledge, shaded with fine tall majestic trees. Here, I said to myself, is the pass, or gates, leading to the Niger. 'The rocks of which the ledge is composed are of a conglomerate, formed with large square pieces of white quartz, imbedded in a shining dark gray substance; the pieces of quartz about an inch square, the strata forming an angle of about $40^{\circ}$ with the zenith. At noon crossed the river Oli, which has a very rocky bed, and is said to be impassable, from the swiftness of the current, in the rainy season. At this place the 
rocks in the river were a dark clay slate: its course was from westnorth-west to east-south-east. 'The head man of the village at the ferry told me that it had its rise in the hills to the north of Niki, ran to the north of Kiama, and entered the Quorra above Rakah. At the place where I and my baggage crossed it was dry ; but all other passengers, not being in the service of a king, are required to cross at the ferry by a canoe, where they have to pay ten cowries a head for each passenger, and twenty cowries for a load for goods. After crossing, I halted at the village of the ferry, which is called Billa, on the south side of the river. I encamped under a shady tree for the superior coolness, though I was offered the best house in the village. The head man brought me a present of a sheep, some yams, milk and honey; and, a short while after my arrival, the head man of the village of Barakina arrived with a sheep, yams, and honey, making an apology for his not being at home when I passed. Alligators are plenty in the river, as one of the carriers, in going to bring water, was chased from the river side by one : parrots, paroquets, and game abound near the banks of this stream. In the evening it was reported to me that the whole of the horses were lost : whether it be to extract a present or not, time will show.

Tuesday, 21st.-It was $8 \mathrm{~A}$. M. before the horses were brought back. I sent all the baggage and stores off, except three boxes, which I gave in charge to the head man of the village, who promised to forward them to me at Wawa. I gave him and the head man of the village of Barakiua two yards of cloth each, with a knife and a few beads, with which they were very well pleased. An escort of four horsemen arrived to conduct me to Wawa, and at 8. 30 A. M. I left Billa and the escort, who had made the head man of the village provide them with a breakfast. The road lay over a plain, well cultivated, and planted with cottons, yams, and corn in a number of places. At 10 halted under the shade of a tree, near the walls of Wawa, until the escort came up, which they did in a short time afterwards, when I proceeded with them into the 
town, to the gate of the governor's house, where I halted under a large spreading tree for upwards of an hour. I then desired Y'arro's messengers to tell the governor that if I was kept longer waiting outside I should return to Kiama ; that I was the king of England's messenger, and would not be kept outside of any door in this way. They went in and told the governor, who sent out to say he was dressing to receive me, and would be out immediately. In a few minutes a number of men came out of the house, and sat down in two rows outside the door; then a high stool was brought out, and placed in the entrance; after which the great man came slowly out of the gate, with a long staff in his hand, and seated himself on the stool. He sent for me. Until then I had not dismounted. I went up and shook hands with him : he kept his hand wrapped up in the sleeve of his tobe, for fear the touch of a white kaffir should kill him. I told him at once who I was, and what I wanted. He said, every thing I wished should be done, and as I must be fatigued with my journey, I should see him again to-morrow. I was shown to a very good house, but found it excessively hot: the thermometer in the shade was $105^{\circ}$ of Fahrenheit, which is higher than it has been since I have been in Africa this time. In the afternoon, the governor sent me a present of a goat, yams, honey, and eggs, and the same from his head man.

I was not a little surprised, towards sunset, by a visit from the king of Dahomey's messengers. I thought that all my prospects were now blasted; that they had been sent to detain me, and bring me back; but my fear's were soon allayed, by their saying that they were on their way home; that they had heard white men had arrived here, and they had come to pay their respects to me; that they had been in Youri, and twelve months since had left Dahomey; that the king of Dahomey had sent them to get a camel, but the war between the people of Youri and the Fellatas prevented any camels coming to Youri. These men brought two muskets to salute me with; they had been here twelve days, and were in- 
tending to leave this for their own country as soon as they could procure an answer from the governor.

I am lodged in the house of a widow, whose husband was one of the governor's head men. She is the only wife that bore children to the deceased, and in consequence was not taken and sold at her husband's death. She wears a rope round her head, another round her neck, and one round her waist, until she has passed her time of mourning, or procures another husband; but I suspect this will be until she dies, as she is ugly in the extreme. I had a visit, amongst the number, from the daughter of an Arab, who is very fair, calls herself a white woman, is rich, a widow, and wants a white husband. She is said to be the richest person in Wawa, having the best house in the town, and a thousand slaves. She showed a great regard for my servant Richard, who is younger and better looking than I am : but she had passed her twentieth year, was fat, and a perfect Turkish beauty, just like a walking water-butt. Ali her arts were unavailing on Richard : she could not induce him to visit her at her house, though he had my permission.

The next day I went, after sending to say I was ready to give the governor his present, to his house, accompanied by his head man, and gave him seven yards of red cloth, seven yards of blue cloth, seven yards of blue silk, an umbrella, ten strings of beads, and a phosphorus box, after showing them off to the greatest advantage, a thing never to be neglected in Africa. I sat down and told him what I have told them all, and which has been so often repeated. He said there were two roads, one where there was war, the other peace. 'The one where there was war' was by Youri; that the sultan of that country was out fighting the Fellatas: the other by the way the merchants went, through Nyffe, which was safe, and he would advise me to go by that road. I thanked him, and said I would follow his advice, for that I had nothing to do with war. Says he, "You are come to make peace among all people, and make the 
kings leave off war." I said, "God willing, I would do what I could." This opinion of my being a peace-maker prevails strongly in all places that I have been in : perhaps it may arise from the people of the coast and those of Dahomey informing them of the active part we take in preventing the slave trade. He said he should send to the sultan of Boussa, and tell him to forward me by the way of Nyffe, with the merchants, as the other road was bad; that he had never had such a valuable present from any one before; and that I should see every thing I pleased in his country. I told him that three white men who were with me had died on the road; that I was very anxious to get to Bornou before the rains, as being a dry sandy country, I considered that there I was safe: but that in this country or Houssa it was very unsafe and unhealthy for white men to be caught by the rains. The governor is a thin, spare, old man; he had on a cap in the form of a foraging cap, with some of the Stuart tartan riband in several folds around it, a white tobe or large shirt, a Moorish kaftan of Manchester cotton, and a pair of sandals on his feet. The room in which he received me had nothing worth note but the stool on which he sat, which had two lizards carved in bas relief on the top, and the heads of two as handles for carrying it. His house is inside a high square clay wall, with one gate on the western side, and consists of coozies, or circular huts, built of clay and thatched, and one square tower of clay, having little projections at each corner, and an ostrich egg on the top of each of the huts.

After returning home I had numerous visitors, who brought presents of rum, palm wine, and pitto, none of which I would accept, nor allow to be brought into the house for the servants; but as for my man Ali, an Arab, whose freedom I had purchased at Badagry and taken as a servant, all my care could not prevent him from getting drunk. He is a confirmed liar and a thief, and I have often regretted that I gave him his freedom, as I cannot well get rid 
of him here. The inhabitants of this place appear to be the most roaring, drinking set of any other town I have yet seen. Last night, until near morning, nothing was to be heard but fiddles, Arab guitars, castanets, and singing.

The Kiama messenger, according to his promise, brought some of the leaves of the tree or bush called by them kongkonie, from the seeds of which the natives extract the poison for their arrows; from the leaves and branches exudes a resinous gum which sticks to the fingers; the flower is small and white, with a very long footstalk; the seeds are enclosed in a long case surrounded by a silky substance; the seeds are small, like caraway seeds, and are boiled to a thick black paste before they are put on the arrows. They say that the seeds are a deadly poison if taken into the stomach; the seeds I have got in the case, but dried, and fit for use.

The king of Dahomey's messengers came to me in the evening and told me they wanted to speak to me, saying they wished to do so privately. I sent Pascoe to one side with them, but they came back observing that they must say it to myself only; their mighty secret was this : that they had been in Youri five months assisting the king of that country against the Fellatas; that, if I either regarded my safety or wished to reach the end of my journey, I ought not to take that road, as I should never get on; that they had stood the brunt of all his battles, and that all their guns but two were burst; that they were now on their way to their own country, but expect to be sent back by the king of Dahomey with a larger force after the rains. They said that Niki was the capital of Borgoo and not Kiama; that it is fifteen days only from Dahomey; that Borgoo and Dahomey are joined together, or two neigh bouring kingdoms; that there are high lills on the road between Niki and Dahomey; that they left the Maha country on their left hand when they came here; that Kiama is five days distant from Niki; that it is from Dahomey the people of these countries receive all 
their rum and European articles. This account I believe to be true, as I liave seen great abundance of rum, pewter, and earthen ware. They begged I would send a letter by them to say I had met them, which I shall do to-morrow. They are much superior looking men to the people of Wawa, and from their knowledge of white men in their own country, have been very civil to me. They seem to entertain a poor opinion of the courage and behaviour of the people of Youri and of this country, and say that with a few men they could take them all.

Thursday, 23d.-I had heard various stories, at different places on the road, concerning the fate of the late unfortunate and enterprising travellers Park and Martin, none of which I considered worth relating except that which I now heard from the governor's head man ; but they all with whom I have conversed agree in asking me if I am not going to take up the vessel, which they say still remains. The head man's story is this: that the boat stuck fast between two rocks; that the people in it laid out four anchors a-head; that the water falls down with great rapidity from the rocks, and that the white men, in attempting to get on shore, were drowned; that crowds of people went to look at them, but the white men did not shoot at them as I had heard; that the natives were too much frightened either to shoot at them or to assist them; that there were found a great many things in the boat, books and riches, which the sultan of Boussa has got; that beef cut in slices and salted was in great plenty in the boat; that the people of Boussa who had eaten of it all died, because it was human flesh, and that they knew we white men eat human flesh. I was indebted to the messenger of Yarro for a defence, who told the narrator that I was much more nice in my eating than his countrymen were. But it was with some difficulty I could persuade him that if his story was true, it was the people's own fears that had killed them; that the meat was good beef or mutton; that I had eaten more goats' flesh 
since I had been in this country than ever I had done in my life; that in England we eat nothing but fowls, beef, and mutton.

The women here are marked on the body somewhat in the manner of the lace on a hussar's jacket: in some, where the skin has not healed properly, it looks very disgusting.

The widow Zuma has been kind enough to send me provisions ready cooked, in great abundance, ever since I have been here. Now that she has failed with Richard, she has offered Pascoe a handsome female slave for a wife, if he could manage to bring about matter's with me. Not being much afraid of myself, and wishing to see the interior arrangement of her house, I went and visited her. I found her house large, and full of male and female slaves; the males lying about the outer huts, the females more in the interior. In the centre of the huts was a square one of large dimensions surrounded by a verandah, with screens of matting all around except in one place, where there was hung a tanned bullock's hide; to this spot I was led up, and, on its being drawn on one side, I saw the lady sitting cross-legged on a small Turkey carpet, like one of our hearth rugs, a large leather cushion under her left knee; her goora pot, which was a large old-fashioned English pewter mug, by her side, and a calibash of water to wash her mouth out, as she alternately kept eating goora and chewing tobacco-snuff, the custom with all ranks, male or female, who can procure them: on her right side lay a whip. At a little distance, squatted on the ground, sat a dwarfish hump-backed female slave, with a wide mouth but good eyes : she had on no clothing, if I except a profusion of' strings of beads and coral round her neck and waist. This personage served the purpose of a bell in our country, and what, I suppose, would in old times have been called a page. The lady herself' was dressed in a white coarse muslin turban; her neck profusely decorated with necklaces of coral and gold chains, amongst which was one of rubies and gold beads; her eyebrows and eyelashes blacked, her hair dyed with indigo, and her hands and feet with henna; 
around her body she had a fine striped silk and cotton country cloth, which came as high as her tremendous breasts, and reached as low as her ankles; in her right hand she held a fan made of stained grass, of a square form. She desired me to sit down on the carpet beside her, which I did, and she began famning me, and sent hump-back to bring out her finery for me to look at ; which consisted of four gold bracelets, two large paper dressing-cases with looking-glasses, and several strings of coral, silver rings, and bracelets, with a number of other trifling articles. After a number of compliments, and giving me an account of all her wealth, I was led through one apartment into another, cool, clean, and ornamented with pewter dishes and bright brass pans. She now told me her husband had been dead these ten years, that she had only one son, and he was darker than herself; that she loved white men, and would go to Boussa with me ; that she would send for a malem, or man of learning, and read the fatha with me. I thought this was carrying the joke a little too far, and began to look very serious, on which she sent for the looking-glass, and looking at herself, then offering it me, said, to be sure she was rather older than me, but very little, and what of that? This was too much, and I made my retreat as soon as I could, determined never to come to such close quarters with her again. During the night squally, with thunder, lightning, and rain.

Friday, 24th.-Amongst my numerous visitors this morning, I had a travelling musician, attended by two boys. His instrument was a violin made of a gourd, with three strings of horse hair, not in single hairs, but a number for each string untwisted; the bow the same; the body of the violin was formed of half a long gourd; the bridge, two cross sticks; the top, the skin of a guana stretched tightly over the edges; the neck was about two feet long, ornamented with plates of brass, having a hollow brass knob at the end. To this instrument was hung a diminutive pair of sandals to denote his wandering occupation, a piece of natron, strings of cowries, and 
stripes of cloth. He said he would take any thing that was given to him. The boys had hollow gourds with stones or beans in them, with which they kept time by holding them in one hand and beating them against the other. The musician himself was past the middle age, his beard being tinged with gray, and neither too long nor too short; his face inclining more to long than oval, with a nose slightly hooked; his forehead high; his eyes large, bright, and clear, with a kind of indefinable expression of half rogue and half a merry fellow, and when he sang he sometimes looked sublime; his mouth and teeth were good; his voice clear and melodious; his stature about the middle size, and spare form; his dress was a white turban and large sky-blue tobe or shirt. He accompanied his instrument with his voice, the boys joining in chorus. His songs were extempore. I should liave taken one down, but found they were all about myself; and a number of visitors coming in, I gave him fifty cowries and sent him away rejoicing. Received a present of a sheep, yams, milk, eggs, and a goat, from the governor.

I went outside the town with Yarro's messenger to see the kongkonie tree which I have before mentioned, and from the seeds of which they are said to extract the poison for their arrows. The tree is a parasite (meaning probably a creeper), about the thickness of a man's thigh at the root, from which shoot up several stems, that ascend the large tree at the root of which it grows, twisting itself round the stem and branches to the top of the tree; the bark of the young branches is like the darkest of the hazel; the stem and older branches smooth and whitish, like the bark of the ash; the flower, which is now fading, has five leaves tapering to a point, from which they have a string about two inches in length hanging; they are about the size of our primrose, but of a darker yellow; the leaves of the tree are rough and furry, exuding a gum that sticks to the fingers; the part which grows from the flower and contains the seeds is about a foot and a half in length, and one and a half or two inches in circumference in the thickest part; the seeds 
are like caraway seeds, and are surrounded by a silky substance; they are boiled until they turn into a paste, when they are fit for use, and put on the arrows. I had a present of five alligators' eggs sent me by the governor: they are only eaten by the principal people, and considered a great delicacy: they were brought from the banks of the Quorra. The taja called upon me, but he appeared still to shuffle off coming to any arrangement, saying he could not say for how much he would carry me to Kano, until he saw whether I was to go with him or not. I observed to him it was very easily said, and that until he told me how much, I would not ask the gorernor to go with him. He said he wanted half the money here. To which I replied, "You must go with this understanding in all future affairs between you and I, that I will not give you one farthing until I arrive in Kano, when, the day after I arrive there, you shall have every cowrie of the money. If you come to any bargain with me, it must be with the understanding that I have no money here." "Well," says he, "I will call tomorrow and see your things, and then come to a written agreement with you-half the money here." 'This taja must take me for a fool ; I will sooner stay here all the rains, than let him have the money and leave me in the lurch.

Saturday, 25th.-Clear and warm. At noon the taja risited me, when, after a great deal of unnecessary palavering and manœuving on his part, we came to the following bargain, - that he is to carry all my baggage and stores to Kano for 200,000 cowries. I also found out that he does not go to Boussa, but crosses the Quorra at a place called Comie, and goes to Koolfu in Nyffe, where he stops for a few days. I am therefore to ask the governor here to carry my baggage to Koolfu, where the taja will find bullocks. I must however go out of the way to visit the sultan of Boussa, as all this part of the country is nominally under him. The sultan of Niki is next to him, and equal to him in power. My baggage, therefore, and stores with my servants must proceed to 
Koolfu without me, as I have no other alternative but to take this route or that of Youri. After the taja left me, I went to the governor, and acquainted him with th agreement $I$ had come to with the taja, who immediately promised to send a messenger with myself to Boussa, and another with my servants and baggage to see them safe to Koolfu. I would not on any account miss the opportunity of going to Boussa, being most anxious to see the spot where Park and Martin died, and perhaps get their papers. If I am detained, my servants go on with the taja; and I have left directions with them how to proceed in the event of my death or other accidents.

Sunday, 26th.- On inquiring to-day of the same person, the governor's head man, concerning the fate of Park and Martin, he said the natives did shoot arrows at them, but not until guns had been fired from the boat: in all other parts of the story he agreed with what he had told before, adding, that the boat was to be seen above water every Sunday. They all treat the affair with a great deal of seriousness, and look on the place where the boat was wrecked with awe and superstition, telling some most marvellous stories about her and her ill-fated crew. I also learnt from this man their manner of burial in Borgoo, which is as follows: they dig a deep round hole like a well; the corpse is put in the hole in a sitting posture, with the wrists bound tight round the neck, the legs bent, and the thighs, legs, and arms, bound tight round the body. 'The grave is made in the floor of the deceased's house, and his horse and $\operatorname{dog}$, if he has any, are killed to serve him in the next world. 'The Mahometans bury in their usual fashion, and have a buryingground on the east side of the town, inside the walls.

Monday, 27th. - Received a present of a goat, two fowls, yams, and milk, from the brother of the governor, who has got a sore leg, and wishes me to cure it. In the afternoon we had thunder, lightning, and rain. I took this opportunity of waiting on the 
governor to press my departure, as the taja is rather too slack for me. I asked him if he would not send me to Koolfu to-morrow, as he saw now that the rains were close at hand. "Oh," says he, " they will not set in these two months, yet it is always thus before the rains." I told him that no one knew the seasons better than I did; and that, if I travelled as slow as I had done of late, I would be caught by the rains in Houssa, and I might as well have a sword run into my breast. He said he would send for the taja to-night, and give me into his charge. I said, I mut go to Boussa, and make a present to the sultan; that if I did not, he would say, a white man has passed through my country without paying his respects to me, or bringing a present: it would be going out of the country like a thief, not like the messenger of the king of England. "Very well," says he, "I will despatch a messenger with you to request he will not detain you. You must send all your things up to my house; I will give them and your servants in charge of the taja, and all will go well; my messenger shall ac-. company them to Koolfu"-(sometimes pronounced Koolfie and Koolfa). He then began asking me if Englishmen would come into the country. "Yes," says I, "if you use them as well as you have done me: there is now a doctor on his way to join me from Dahomey." He said he would be very glad to see him, and would forward him on to me. I asked him if this country or Borgoo owed any allegiance to Yourriba: he said, none; and laughed at the idea. He said he owed allegiance to Boussa, as Kiama, Niki, and Youri did; that he was separated from Kiama by the brook I halted at the second day I left that place, and that the province of Wawa extended as far south as Rakah; that Kiama owed no allegiance to Yourriba, but was a province of Borgoo, subject to the sultan of Borgoo, who was the head of all : he added, the sultan of Boussa could take Yourriba whenever he chose, but, says he, the Fellatas will take it now. I asked him if he thought the sultan 
of Boussa would give me the books that were found in the boat belonging to the white men lost there. He said, if there were any, he would certainly give them to me, as they were of no use to him, he could not read; and he then related to me the same story nearly that his head man had told me of that affair, and asked me if the unfortunate people were not my countrymen, and had great riches: I said they were, but that they were not rich, but honest men like myself; that one, the head man, was a doctor.

Tuesday, 28th.-This morning I visited the governor's brother who has got the sore leg, as he had sent a fee, and could not come and see me. His left ankle was dreadfully ulcerated and swelled, and had been in the same state since the last rainy season. The leg was thin and wasted; and he complained of suffering much pain. He could move his toes very well; and inquiring if it was the effect of a hurt, he said no, that it had come on at the beginning of the last rains. I directed him to wash it clean night and morning with warm milk and water, to apply poultices night and day until the swelling was reduced, and on no account to drink spirits or palm wine: an advice which he did not at all admire, as he said when he drank it eased his pain and gave him sleep. I desired moreover that when the swelling in his leg was reduced by the poultices, he should put clean fat on a soft rag and lay over it, and on no account to drink any thing stronger than water. After my return home he sent me a present of a sheep, four fowls, eggs, milk, and honey. I now began to prepare for starting to Boussa in the morning at daybreak, but the taja is working against me, and I doubt being able to get off, as I have just learned that he does not leave this until Saturday next, and wishes to detain me also. The sky being clear, before the moon rose I was able to get the meridian altitude of the star Dubbe in the Great Bear, which gave the latitude of my house in Wawa, $9^{\circ} 53^{\prime} 54^{\prime \prime}$ north. Its longitude I calculate to be $5^{\circ} 56^{\prime}$ east. 
Wednesday, 29th.-Wawa is the capital of a province of the same name in the kingdom of Borgoo; it is in the form of a square, and may contain from eighteen to twenty thousand inhabitants. It is surrounded by a good high clay wall and dry ditch; and is one of the neatest, most compact, and best walled towns between this and Badagry. The streets are wide, spacious, and airy, the houses of the coozie, or circular hut form ; the huts of each house being connected by a wall, forms an airy and open space inside, and does not take away from the regular appearance of the houses. One of the coozies next the street has two doors, which forms an entrance into the interior, into which the other coozies open. 'The plan of the one in which I lived may serve for all, except the governor's and that of the widow Zuma. This plan will afford a fair specimen of the accommodations of Wawa. The governor's house is surrounded by a clay wall, about thirty feet high, in the form of a square, having large coozies, shady trees, and square clay towers inside.

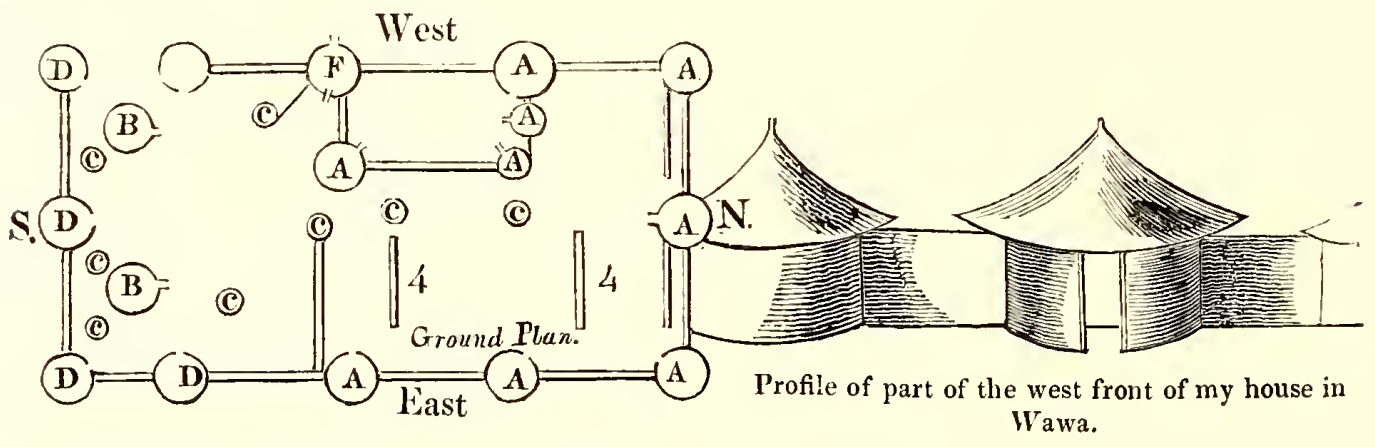
A. Sleeping and sitting-rooms.
c. Little houses for holding grain.
F. House of entrance.
B. Stables.
D. Houses of the slaves.
4. Places for cooking.

The marriages of the Wawanies are very simple. The pagans make up matters with the girl first, give the father or mother a present, and all is right. 'The Mahometans read the fatha, and make a present ; read it again, and part, when tired of one another. 
The virtue of chastity I do not believe to exist in Wawa. Even the widow Zuma lets out her female slaves for hire, like the rest of the people of the town. Neither is sobricty held as a virtue. I never was in a place in my life where drunkenness was so general. Governor, priest, and layman, and even some of the ladies, drink to excess. I was pestered for three or four days by the governor's daughter, who used to come several times in a day, painted and bedizened in the highest style of Wawa fashion, but always half tipsy; I could only get rid of her by telling her that I prayed and looked at the stars all night, never drank any thing stronger than roa-in-zafir, which they call my tea,--literally hot water : she always departed in a flood of tears. Notwithstanding their want of chastity, and drunkenness, they are a merry people, and have behaved well to me. They appear to have plenty of the necessaries of life, and a great many of the luxuries, some of which they would be better without; this being the direct road from Bornou, Houssa, and Nyffe, to Gonja, Dahomey, and Jannah. Since the war between the Fellatas and people of Yourriba, they are able to procure plenty of European articles, such as pewter jugs and dishes, copper pans, earthenware, Manchester cottons, \&c. 'Their fruits are-imes, plantains, bananas, and several wild fruits in the season. Their vegetables are yams, calalou, or the leaves of a plant which they use in their soups, as we do greens or cabbage ; grain, doura, Indian corn, and millet. Fish they procure in great plenty from the Quorra and its tributary streams: those I have seen were all smoked, and principally a kind of catfish. 'Their best and largest horses come from Bornou : the native breed are small, like the Shetland ponies, hardy, active, and generally of a brown or mouse colour. Oxen are in great plenty, principally in the hands of the Fellatas; sheep and goats are also plentiful; domestic fowls plenty and cheap; honey and bees' wax abundant; ivory and ostrich feathers they say are to be procured in great plenty, but they can get no sale for them. 
The country abounds in wild animals of all the different kinds to be found in Africa. Slaves are numerous : the males are employed in weaving, collecting wood or grass, or on any other kind of work ; some of the women are engaged in spinning cotton with the distaff and spindle, some in preparing the yarn for the loom, others in pounding and grinding corn, some cooking and preparing cakes, sweetmeats, natron, yams, and accassons, and others selling these articles at the markets; the older female slaves are principally the spinners. The mere labour is very light, and a smart English servant would accomplish their hardest day's work in one hour: but if their labour be light their food is also light, being confined to two meals a day, which almost invariably consist of paste of the flour of yams, or millet, in the morning about nine o'clock, and a thicker kind, approaching to pudding, after sunset, and this only in small quantities ; flesh, fowl, or fish, they may occasionally get, but only by a very rare chance. Their owners, in fact, fare very little better: perhaps a little smoke-dried fish, or some meat now and then ; principally only a little palm oil, or vegetable butter, in addition to their paste or pudding; but they indulge freely in drinking palm wine, rum, and bouza.

Of the slaves for sale I can say but little, and a stranger sees very little of them. In fact when not going on a journey to some slave mart, or sent out to the wells or rivers in the mornings to wash, they are seldom seen. Even then they are fastened neck to neck with leather thongs; and when this duty is over, they are confined closely in the houses until they are marched off. When on their march, they are fastened night and day by the neck with leather thongs or a chain, and in general carry loads; the refractory are put in irons, in addition to the other fastening, during the night. They are much afraid of being sold to the sea coast, as it is the universal belief that all those who are sold to the whites are eaten ; retorting back on us the accusation of cannibalism, of which 
they have perhaps the greatest right to blame us. The slaves sold to the sea coast are generally those taken in war, or refractory and intractable domestic slaves. Nyffé at present is the place that produces the most slaves, owing to the civil war raging in that country.

The people of Wawa would take beads in exchange for any articles their country might produce; also brass bracelets for the arms and legs ; brass, copper, pewter, and earthenware dishes ; Manchester cottons of gaudy colours, and calicoes. Their arms are bows and poisoned arrows, and light spears. They say they do not like war, but appear to be very tenacious in not permitting interference with their country; and they like the Fellatas better than their neighbours of Kiama, of whom they are very jealous. They have a good character for honesty; are cheerful, good-natured, and hospitable; and no people in Africa that I have met with are so ready to give information about the country as they are; and, what is very extraordinary, I have not seen a common beggar amougst them. 'They deny their Borgoo origin, and say they are descended from the people of Nyffé and Houssa. Their language is a dialect of the Yourriba: but the Wawa women are very good-looking, and the Youriba women are not: the men are strong and well made, but have a debauched look. Their religion is partly a loose Mahometanism, and partly pagan. The most pious of the former can only say a few prayers, or go through the necessary forms, and are called Malem, or learned : the latter are called Kaffirs; and what they worship it is hard to tell; every man choosing lis own god, which they pray to that he may intercede with the Supreme Being for them; and they offer sheep, dogs, and sometimes a bullock, according to the benefit they expect. A woman is sent to the market and sold, if, when she has a child at the breast, sle is known to go with a man, and, in addition, loses her child, and is flogged.

In this country, as well as in all others I have passed between 
this and the sea, I have met with tribes of Fellatas, some of whom are not Mahometans, but pagans. 'They certainly are the same people, as they speak the same language, have the same features and colour, except those who have crossed with the negro. They are as fair as the lower class of Portugueze or Spaniards, lead a pastoral life, shifting from place to place, as they find grass for their horned cattle, and live in temporary huts of reeds or long grass.

Thursday, 30th.-Having had every thing prepared last night for starting this morning at day-break, I went and took leave of the governor, who repeated his promises of sending my baggage on to Koolfu. On my return from the governor, I met a messenger of the sultan of Boussa, who had been sent expressly for me. He said he would just wait on the governor, and deliver a message, and follow me. I left Wawa, mounted on an old red roan mare of the governor's, on a good road, leading through a woody country, witl numerous plantations of yams, and Indian corn. At 8. 30 A. M. passed a village about a quarter of a mile from the south side of a range of low rocky hills, running in a direction from east-south-east to west-south-west by compass. The rocks were composed of pudding-stone, the white quartz pebbles of which were square, not rounded, and imbedded in a gray substance. At the end of an opening in the range was a beautiful sugar-loaf mountain, overlooking all the rest, and bearing from the village east-south-east, distance half a mile. This I presumed to call Mount George, after his present majesty George the Fourth. After passing the village and entering amongst the hills, I found the valleys well cultivated, and planted with yams, corn, and maize, but the road winding and rocky. At $10 \mathrm{~A}$. M. came to the village of Injum, the first belonging to the province of Boussa. Here I halted, until the messenger, who had joined me some time before, got his breakfast. This village is on the north-east side of the hills. Amongst the number of people who came to look at me was a woman, whose face, 
neck, right breast, and part of her right arm, were covered with a scurf, like a person very ill with the small pox: the borders of the scurf were bare, raw, and inflamed. This is the disorder the young man's mother died of, to whom I gave the medicines at Kiama. When the disease reaches the toes and fingers, they first contract, and then drop off; when, in a short time after, the unfortunate person is relieved by death, as they have no cure for it, nor do they attempt any. I called the woman, and asked her if she suffered much pain: she said no, nor did it itch. She sent for some yams, and offered them, as she said my looking at her would do her good.

At 10. 30 the messenger having finished his breakfast, we left Injum. He gave me his horse to ride, as I could not get the old Wawa mare to go on without a great deal of beating. At noon halted at the side of a brook, to water the horses. Here end the hills and the pudding-stone of which they are composed, and the rocks are now a dark gray slate, which moulders away with the rains, the soil a strong blue clay, with deep gullies formed by the rains. At 1 left the brook: the country thickly wooded with tall trees, amongst which are a number of the acacia or mimosa, many of them thrown down by the elephants, for the purpose of feeding on the upper and tender branches. The traces of elephants, buffaloes, and the larger kind of antelopes called in Bornou corigum, are numerous. At 2. 40 halted at a village of the Kumbrie, or Cambrie, a race of Kaffirs inhabiting the woods, on both sides of the river. They made a great difficulty in procuring me a drink of water, so I mounted and left them, and at 3.30 arrived at a branch of the Quorra, called the Menai, close to its junction with a second branch. The Menai is about twenty yards in breadth, and about two fathoms in depth; the current hardly perceptible, and the water dark and muddy; that of the branch into which it runs being about thirty yards in breadth, with a strong current, about 
three or four knots, throwing a back-water up the Menai. The island on the other side of it is low and swampy, and covered with high reeds; the colour of both the streams red and muddy, as if in flood; but the messenger, on my asking if this was the case, said no, that the river was now at its lowest mark, and pointing to a place on the opposite bank of the Menai, about fifteen feet above the present level, said the river rose to that height during the rains. The trees on both banks were close down to the water's edge, and the branches were in the stream, and every now and then a branch would be broken off, and washed away by the strength of the current. From this, and the muddiness of the water, I concluded it was rising; but certainly the inhabitants must know best : had I not made inquiry, I should certainly have said it was rising. 'The canoe being on the other side of the Menai, the messenger stripped off his tobe, and swam over for it. After crossing and swimming the horses over, in about a quarter of an hour's ride I entered the walls of Boussa, by the western gate. The walls appeared very extensive, and are at present under repair. Bands of male and female slaves, accompanied by drums and flutes, and singing in chorus, were passing to and from the river with water, to mix the clay they were building with. Each great man has his part of the wall to build, like the Jews when they built the walls of Jerusalem, every one opposite his own house.

I was much surprised, after entering the gate, to see only clusters of huts here and there, and no regular town, as I had been led to expect. I remained under the shade of a tree until the messenger went and acquainted the sultan of my arrival. On his return I accompanied him up to the sultan, whom I found sitting under a small projection of the verandah of one of his coozies : his midaki, or principal wife, sitting alongside of him. To this personage I had been advised by the widow Zuma to pay particular attention, as she was every thing with the sultan. He received me very 
kindly, and said the sultan of Youri had kept seven boats waiting for me for these last seven days to take me up the river to Youri. I said I was much obliged to the sultan of Youri, but that I did not intend going that way, as the war with the Fellatas had shut up the communication between Bornou and Youri; that with his permission I would go by the way of Koolfu and Nyffe, where there was no war. He said I was right, and that it was good for me that I had come to see him; that I should take what path I chose.

We then parted, he ordering his head man to take me to a house. He would have come with me himself, but the midaki pulled him back; she had acted, during the time I was there, as prompter. The sultan is a fine looking young man, about twentyfive or twenty-six years of age, five feet ten inches high, with a high forehead, large eyes, Roman nose, decent lips, good teeth, short chin covered with about an inch and a half of beard, more of a spare than robust make. He was dressed in a white tobe, striped Moorish kaftan, with a red Moorish cap on his head. The midaki appears somewhat older, below the middle size, with nothing remarkable about her but her voice, and a winning womanish way, sitting on his left side, a little behind him, with her arm half around his neck. His house does not differ from those of other people, except the huts being a little larger, and surmounted by ostrich eggs. I found my house a very good one, with three rooms or huts, and a shade for the heat of the day; and the sultan and midaki sent me a sheep, yams, fish, milk, honey, and eggs.

Friday, 31st.-This morning I waited on the sultan with my present, which consisted of eight yards of red cloth, eight yards of blue, eight yards of silk, a blue silk umbrella, an African sword, three pair of white cotton stockings, three pair of gloves, two phosphorus boxes, three clasp-knives, and three pair of scissars, a mock-gold chain, beads, and coral ; for the midaki, pictures of the king, and royal family, \&c. I displayed my present to the best ad- 
vantage, and explained the uses of the different articles. The sword he was delighted with, and the chain, I saw, had won the midaki's heart. She first put it around her own neck, then taking it off, and putting it around the sultan's, looked up in his face with as sweet an expression of countenance as ever I saw. Upon the whole, my present appeared to have the effect I wished. After giving me a great many thanks, and the presents were taken away, he began again about Youri : said, that Yarro of Kiama had informed him that I was going there. I said, I meant to have gone there, but that I should now defer my visit until my return; that the rains were now at hand; that by the way of Youri there was war, and I could not get to Bornou before the rains; that remaining in Youri or Houssa during that season would kill me, and they had better put a sword through me at once than detain me. He said there was no sultan between Koolfu and Guari. I told him the taja had engaged to find me bullocks to carry my baggage to Kano. He then asked me when I wished to go away. I replied, "To-morrow." "Well," says he, "you shall go in the afternoon." I said I would piefer daybreak, as I wished to make observations at the river side, and see my baggage safely over. I had some apprehension that the king of Youri, should he hear that I am going by the way of Koolfu, might outwit me; on which account I mentioned my preferring to travel in the morning. "Well," says he, "you shall go when you please."

This point being settled, I asked him to lend me a horse and saddle, which he promised to do. I next inquired of him after some white men who were lost in the river near this place twenty years ago. He seemed rather uneasy at this question, and I observed that he stammered in his speech. He assured me he had nothing belonging to them; that he was a little boy when the event happened. I said, I wanted nothing but the books and papers, and to learn from him a correct account of the manner of their death ; 
and that with his permission, I would go and visit the spot where they were lost. He said no, I must not go; it was a very bad place. Having heard that part of the boat still remained, I asked him if it was so: he replied, that such a report was untrue; that she did remain on the rocks for some time after, but had gone to pieces and floated down the river long ago. I said if he would give me the books and papers it would be the greatest favour he could possibly confer on me. He again assured me that nothing remained with him, every thing of that kind had gone into the hands of the learned men; but that if any were now in existence he would procure them and give them to me. I then asked him if he would allow me to inquire of the old people in the town the particulars of the affair, as some of them must have seen it. He appeared very uneasy, gave me no answer, and I did not press him further. In the afternoon the sultan came galloping up in front of my house, a man running after him, holding the umbrella I had given him: but the bearer could not keep up with the horse, or hold it over his head.

In the evening I was visited by the sultan and midaki, and the king of Youri's messenger with them. 'I'he messenger said his master had sent provisions and every thing for my voyage up the river to Youri. I told him I could not but feel much obliged to the king of Youri for his kindness; but that the rains were close at hand, and the road between Youri and Bornou shut up by the war ; that on my return, after the rains, I should certainly visit the king, for his kindness on this occasion. The sultan of Boussa said I should be making an enemy of the king of Youri if I went away without seeing him or sending him a present. I said I really had nothing here to give; that if the messenger of the king of Youri would accompany me to the ferry where my baggage was, I would give him as good a present as I was able; but that I had now very little to give. 'The Youri messenger was very anxious that I 
should go with him; but the midaki, whose heart the gold chain has won, fairly beat him off the field, and it was decided that I am not to go to Youri. The sultan made a great many inquiries about England, and asked me two or three times if I had not come to buy slaves. I laughed in his face, and told him there was nothing we so much abhorred in England as slavery; that the king of England did every thing to prevent other nations buying slaves; that the slave trade was the ruin of Africa; that Yourriba presented nothing but ruined towns and deserted villages, and all caused by the slave-trade; that it was very bad to buy and sell men like bullocks and sheep. It was now nearly dimner-time, and he said he would come and see me at night.

At eight in the evening the sultan came, accompanied by the midaki, and one male slave. He began again about Youri ; but I repeated what $I$ had said before. He then asked me if the king of England was a great man. "Yes," I said, "the greatest of all the white kings." "But," says he, "you live on the water ?" "Oln no," I said, "we have more land than there is between Boussa and Badag (as they call Badagry), and more than five thousand towns." "Well," says he, "I thought, and always have heard, that you lived on the water. How many wives has the king ?" "Only one wife," I said. "What!" says he, "only one wife?" "Yes," says I; "no man is allowed more than one wife, and they hang a man if he has two at one time." "That is all very good for other men," says he ; "but the king having only one wife is not good." When I told him, if the king had a daughter and no son, she would rule the kingdom at her father's death, he laughed immoderately, as did the midaki, who was apparently well pleased with the idea of only one wife, and a woman ruling. I asked him who were the first people who inhabited this part of the country. He said the Cambrie; that his ancestors were from Bornou; that the sultan of Niki was descended from a younger branch of his family; that his ancestors and people had 
come into this country a long time ago ; that his family were descended from the sultans of Bornou ; and that they had paid the latter tribute until, of late years, the road had been shut up; but that he would pay it all up whenever the road was open; that the sultans of Youriba, Niki, Kiama, Wawa, and Youri, paid tribute to Bornou. I then asked him at what place the river entered the sea. He replied he did not know: but he had heard people say it went to Bini, which is the name they give to Bornou. I asked if he had ever seen any of the Bini people, or if they come up as far as this by the river. He said, no, he had never seen any of them; that he understood they never came higher up the river than Nyffe or Tappa (as they call Nyffe). He remained with me until near morning, and when he was gone, finding I could not sleep, and hearing the sound of sweet-toned instruments, I sent for the musician, and made him play and sing to me. On sending him away, I desired him to call in the morning and I would pay him, and to bring his instrument with him.

Saturday, 1st April.-Morning cool and cloudy, with a little rain. 'The Houssa musician came to his appointment, and I made him play and sing. I made a sketch of his instrument, which I asked him to sell to me; but he said he had played on it to his father and mother, and they were pleased with it ; they were now dead, and he would not part with it. My servant Ali was cooking a fowl for my breakfast, and having occasion to call him, he came with a knife in his hand; on seeing which, the musician started, and ran as if he had been going to be put to death instantly. The women in the house, when they saw him run, rolled on the ground, and laughed at the poor man's fright. After breakfast I visited the sultan, and asked him to be allowed to depart, as my baggage was to have been at the river-side yesterday. He said I must not leave him to-day, and that when I came back I must stay forty days with him. I was visited by a great number of 
people, amongst which were many Fellatas, the chief of whom sent me a sheep, honey, and milk. The sultan, when I inquired of him again to-day about the papers of my unfortunate countrymen, said that the late imam, a Fellata, had had possession of all the books and papers, and that he had fled from Boussa some time since. This was a death-blow to all future inquiries here; and the whole of the information concerning the affair of the boat, her crew, and cargo, which I was likely to gain here, I have already stated. Every one in fact appeared uneasy when $I$ asked for information, and said it had happened before their remembrance, or that they did not see it. They pointed out the place where the boat struck, and the unfortunate crew perished. Even this was done with caution, and as if by stealth; though, in every thing unconnected with that affair, they were most ready to give me what information I asked; and never in my life have I been treated with more hospitality or kindness.

The place pointed out to me, where the boat and crew were lost, is in the eastern channel: the river being divided into three branches at this place, not one of which is more than a good pistolshot across. A low flat island, of about a quarter of a mile in breadth, lies between the town of Boussa and the fatal spot, which is in a line, from the sultan's. house, with a double-trunked tree with white bark, standing singly on the low flat island. The bank is not particularly high at present, being only about ten feet above the level of this branch, which here breaks over a gray slate rock, extending quite across to the eastern shore: this shore rises into gentle hills, composed of gray slate, thinly scattered with trees; and the grass at this season gives it a dry and withered appearance.

The city of Boussa is situated on an island in the river Quorra, and is in latitude $10^{\circ} 14^{\prime}$ north, longitude $6^{\circ} 11^{\prime}$ east. 'The course of the Quorra here is from north-north-west to south-south-east by compass; and, as they informed me, is full of islands and rocks as far 
up the river as they were acquainted with it, and the same below. Boussa stands nearest the westermmost branch, which is called by the natives the river Menai ; the other two branches have no other name than the Quorra. The Menai's stream is slow and sluggish; those of the other two strong, with eddies and whirlpools breaking over rocks, which in some places appear above water. Boussa island, as I shall call it, is about three miles in length from north to south, and a mile and a half in breadth at the broadest part. A ridge of rock, composed of gray slate, runs from one end of the island to the other, forming a precipice from twenty to thirty feet high on the eastern side, and shelving gently down on the west : below this precipice extends a beautiful holm or meadow, nearly the whole length of the island, and about three hundred yards broad, to the banks of the river, where there are several rocky mounds, on which villages to the number of four are built. 'The wall of Boussa is about a quarter of a mile from the banks of the Menai, and unites with the two extremities of the rocky precipice, where they fall in with the banks of the river; and may be about three quarters of a mile or a mile in length. The houses are built in clusters, or forming small villages, inside the wall, not occupying above one-tentl of the ground enclosed. Outside the walls, on the same island, are several villages, with plantations of com, yams, and cotton. The language of the people of Boussa is the same as the other states of Borgoo, and appears to be a dialect of the Yourriba: but the Houssa language is understood by all classes, even by the Cambrie. I should not think that the whole of the inhabitants living between the wall and the river amounted to more than ten or twelve thousand; but I was informed that the state of Boussa was more populous than all theother provinces of Borgoo; and that, next to Houssa, the sultan of Boussa, from that state alone, could raise more horse than any other prince between Houssa and the sea. The inhabitants, with a very few exceptions, are pagans, as is the sultan, though his name 
is Mohamed. Milk is his fetish, and which he, therefore, does not taste. This I learnt when he drank tea with me. They eat monkeys, dogs, cats, rats, fish, beef, and mutton; the latter only on great occasions, or when they sacrifice. 'This morning when I was with the sultan, his breakfast was brought in, which I was asked to partake of. It consisted of a large grilled water-rat with the skin on, some very fine boiled rice, with dried fish stewed in palm oil, and fried or stewed alligator's' eggs, and fresh Quorra water. I eat some of the stewed fish and rice, and they were much amused at my not eating the rat and the eggs. Their arms are, the bow, sword, spear, and a heavy club of about two feet and a half in length, bent at the end and loaded with iron: their defensive armour is a tanned leather shield, of a circular form, and the tobe or large shirt gathered in folds round the body, and made fast round the waist with a belt.

From the front of the Sultan's house they pointed out to me a high table-topped mountain, bearing by compass north-north-east, distant from twenty-five to thirty miles. On the south-west side of this mountain they say Youri lies; and the Quorra runs past the west end of the mountain.

When I went to take leave of the sultan and midaki, the latter made me a present of a fine young native horse; his brother, a fine young man, accompanied me; the head man, or, as he is called, the aroikin sirka and the principal people of Boussa, also accompanied me to the banks of the Menai, when I crossed and took leave of them ; the messenger of the sultan of Boussa, and a messenger of the king of Youri, to whom I had promised to deliver a present for his master when I got to the ferry, attending me. Thus ended my visit to Boussa. 


\section{CHAPTER IV.}

JOURNEY FROM BOUSSA, ACROSS THE FERRY OF TIIE QUORRA, BY GUARRI AND ZEGZEG, TO THE CITY OF KANO.

Leaving the banks of that branch of the Quorra called Menai at 10. 30 in the morning of the $2 \mathrm{~d}$ of April, I travelled on the Wawa road as far as the Cambrie villages mentioned on my way to Boussa. Here we turned off south-south-west $\frac{1}{2}$ west., sometimes near the banks of the river; the road winding, woody, and rocky, and cut up into deep ravines, in which there were pools of water, and near which were the traces of numerous wild beasts, but few were seen, and those were of the large species of antelope. At 2 P.M. halted at one of the rocky ravines to water the horses. I heard the Quorra roaring as if there was a waterfall close at hand. I ascended the high rocky bank of the ravine, and the rocky ridge which here formed the banks of the river, where I saw the stream rushing around two low rocky and wooded islands and among several islets and rocks, when taking a sudden short bend to the westward, the waters dashed with great violence against the foot of the rock on which I sat, and which might form a precipice of about fifty feet high above the river. Just below the islands, and nearly half way across, the river had a fall at this time of from three to four feet; the rest of the channel was studded with rocks, some of which were above water. It occurred to me that even if Park and Martin had passed Boussa in safety, 
they would have been in imminent danger of perishing here, most likely unheard of and unseen. When I attempted to get up and mount my horse, after finishing a rough sketch of the scene, I was taken with a giddiness, and lost the use of my limbs and sight. 'They carried me under the shade of a tree, where I broke into a profuse perspiration; and at 3.30 being much relieved, I mounted and rode half an hour, when I halted at a village of the Cambrie, called Songa, the inhabitants of which gave me the best hut in the village: but bad was the best; it was infested with rats, scorpions, and centipedes, and the furniture consisted of old nets, rotten wood, and broken gourds: I therefore left it, and remained on a mat in the open air all night. The head man of the village gave me a sheep and some yams, and at my request sent one of his young men to the ferry, to see if my baggage and servants had arrived. I gave the sheep and yams to the two messengers and their attendants. The young Cambrie man returned about midnight with an answer from the taya, saying that Richard would be up with the baggage at the ferry in the morning.

Monday, 3d.-Morning clear and cool. These Cambrie appear to be a lazy, harmless race of negroes; and, as I was informed, inhabit the villages in the woods near the Quorra, in the states of Boussa, Wawa, and Youri. They plant a little corn and yams, and keep a few sheep and goats. The men employ their time in hunting, fishing, and sleeping; the most laborious work falling on the women. 'They are apparently a mild people; in general tall; more stupid-looking than wild; go with very little clothing, seldom any thing more than a skin round the waist. The young people of both sexes go entirely naked until they have cohabited, when they put on a skin, or tobe, as their circumstances will afford. They are, from their unwarlike and mild dispositions, often very ill used and imposed upon. When any of their rulers has a sudden demand for slaves or sheep, they send and take away from the poor 
people their children or their flocks; and any of the slaves of the sultans passing through their villages live at free quarters. They are pagans; and their temple here was a platform raised about five feet from the ground, on which were piled the heads of the hippopotamus and the alligator. The upper and under jaws of the alligators appeared in all to be of an equal length. I took some of the teeth from one that was last offered. Their language differs from that of the surrounding inhabitants.

'The Quorra at this village was in one whole stream, and not above three-fourths the breadth of the Thames at Somerset House at high water, with a current from about two to two and a half or three knots: the colour of the water red and muddy: the banks on each side the river rising to the height of forty-five or fifty feet; in some places rocky: about a quarter of a mile below, it divided into three rocky streams.

At 7. 30 A.M. left Songa: the road through a woody country, cut up by deep ravines with very rocky beds: the rocks mostly of red and gray granite. At 9 A. M. passed between the east end of a rocky hill, composed of porphyry, and the river; the hills on the east side appearing of the same: the river running with great force through this natural gap, which appeared as if cut on purpose to let the waters through. The river between Songa and this is full of rocky islets and rapidis. After having passed the hill about a mile, the western bank shelved away from the river, leaving a high ridge by the river side, composed of sand and clay, with occasionally ridges of clay-slate, between which and the high ground it appeared as if it had formerly been the bed of the river, and is now a swamp. The ridge close to the river was studded with villages; the river full of small rocky islands, and occasionally rapids. At 10. 30 arrived at the village of Comie, or, as it is more commonly called, Wonjerque, or the king's ferry. Here the river is all in one stream ; and this place is the great ferry of the caravans to and from Houssa, Nyffe', \&c. The village is built on the high ground, the 
bank shelving gradually down to the river side, where there is a second temporary town composed of the huts of the merchants: here and in the village all was bustle and confusion. A caravan going to Gonja was halted on the eastern bank; on the western, the goffle from Gonja, with kolla nuts, \&c. 'The village was filled with horses and men dressed out in their gayest trappings: here merchants were offering horses for sale; there their slaves, with gay glass beads, cords of silk, unwrought silk, and tobes and turkadoes for sale; some dancing and drumming; while others, more wicked, were drinking and rioting. I was provided with a good house, and received presents of milk, honey, eggs, ducks, sheep, and goats, as soon as it was known I had arrived; but I returned the whole of them, and said I would accept of nothing until my servants and baggage arrived. Several people came and said they had left Wawa early in the morning, and that my baggage was on the road. The widow Zuma, who is at a neighbouring village, sent me boiled rice and a fowl, and also an invitation to go and stop at her house until my things came, and I should cross the river; but my anxiety for my baggage, and my being rather unwell, prevented me accepting her invitation. I had a visit from the taya, who declares the baggage will be here in the course of a short time. He has now changed his tone: he says I must buy bullocks and pay for them at once, as he will not carry my baggage : he will buy the bullocks for me, and find men to drive them; that he will sell me those which he has bought from the widow; and that he will trust to my generosity for a present when I arrive at Kano; that my baggage, he said, would be here directly, and advised me to go and stop at the widow's until it came. Towards evening my anxiety was very great on account of my baggage, as no appearance of it, or any tidings that 1 could depend upon was to be learnt. The governor's son of Wawa, who is here, offered to go to Wawa and see what was the reason they had not come.

Tuesday, 4th.-I found on his return from Wawa, to my great 
surprise, that my baggage would not be allowed to come until the widow Zuma went back to Wawa. "What have I to do with the widow ?" I asked him. "Yes, you have," says he, "and you must come back with me and fetch her." "Not I," I answered ; "what have I to do with her? If I were governor of Wawa I would bring her back if I wanted her, but I am a stranger." "Then," says he, "I will go if you will send a token and a message, to say I come from you." I gave him my umbrella, but no message, declaring I would not send any. The governor's son went to the widow, and I went to Wawa, where I arrived at noon. My trusty servant Richard arrived at the same instant from Boussa, where he had been to seek me, and acquaint me of the detention of my property : his only guide, a boy whose language he did not understand, or any other but his own native English. He had seen the sultan and midaki, who understood from the little boy who accompanied him what he had come for. They treated him with great kindness, making him remain all night; and in the morning sent him with two armed men to protect him and to find me, and to desire the governor of Wawa to allow my things to go instantly : a convincing fact that the minds of men here must be much changed for the better since the days of Park and Martin. He had left Wawa yesterday, to come and inform me of the detention of my baggage, and the cause why; which was the widow Zuma's having left Wawa about half an hour after I did, with drums beating before her, and a train after her, first calling at my house before she waited on the governor; giving Pascoe a female slave for a wife, without the governor's permission, which I had allowed him to accept; and the widow's declaration before she went away, that she intended following me to Kano, and come back and make war on the governor, as she had done once before.

I was glad to find all my things safe; and was more amused than vexed to think that $I$ had been so oddly let into the politics 
of Wawa, and that the old governor meant me no larm, but just to let me see his consequence before I left Wawa. I certainly never would have thought that the widow Zuma would have been at the head of the malcontents in Wawa. I was now let into their politics with a vengeance; and it was believed I was taking a very great share in them. It would have been a fine end to my journey indeed, if I had deposed old Mohamed, and set up for myself, with a walking tun-butt for a queen.

I sent to the governor the instant of my arrival at Wawa, to say I was ready to wait on him. I had tea to refresh me and clear up my ideas; and went, accompanied by his head manء My servant Ali brought the rifle, which was loaded; but I ordered him back with a severe reproof, as I always make a point of going unarmed; as the least show of fear or distrust would most likely cause me to pay dearly for my unnecessary caution. The head man said, "Ah! dua, dua," or that I had taken medicine to keep me from harm. I found the governor just roused from his noonday nap, which was done by sound of horn. I put on as many smiles as I was master of, shook hands with him, and asked how he did, and how he had been since I last was blessed with the sight of him. I told him that I had seen the sultan of Boussa, and said what a good and generous man he was; and how well he and the midaki, his wife, and the governor's sister, had behaved to me. I then said, I was surprised that my things had not come to the water side, according to his promise. He asked if the widow was not going to take them, as he thought she was. I said, I had nothing to do with the widlow; I was a servant of the king of England, and it was to him I looked; that I did not know the widow before I came here. "Is she not going to Houssa with you? if she is greater than me, let her take them." I said, no; it was he, and not the widow: I had nothing to say to her; and I would thank him to send me and my things off as soon as pos- 
sible. "As soon as the widow comes back," says he, "you shall go, not until then : send for her." I said, I would not send for her ; I had nothing to do with her. "You allowed your servant to take a female slave from her; send her back; and if the widow comes back to-night you shall go to-morrow." I said, as to the widow's coming or going, it was nothing to me: with respect to Pascoe's returning the girl, that was his affair ; and that no offence had been meant to the governor in allowing him to accept her. He said, return her, and he would give him another; and if the widow came to-night $I$ should go in the morning: she was his enemy, and was gone to stir up war against him, as she had done once before. I said, he might blame his head man for my acquaintance with the widow: he was present when she first came to my house; and, as she was an enemy of the governor, he ought to have told me then, and I, as a stranger, and the governor's guest, would not have allowed her to come to my house. We parted after this, and in the evening he sent me a present of one fowl, yams, milk, and honey.

Wednesday, 5th._-This morning the widow arrived in town, with a drummer beating before her, whose cap was bedecked with ostrich feathers; a bow-man walking on foot at the head of her hor'se; a train behind, armed with bows, swords, and spears. She rode a-straddle on a fine horse, whose trappings were of the first order for this country. The head of the horse was ornamented with brass plates, the neck with brass bells, and charms sewed in various coloured leather, such as red, green, and yellow; a scarlet breast-piece, with a bright brass plate in the centre; scarlet saddlecloth, trimmed with lace. She was dressed in red silk trowsers, and red morocco boots; on her head a white turban, and over her shoulders a mantle of silk and gold. Had she been somewhat younger and less corpulent, there might have been great temptation to head her party, for she has certainly been a very handsome 
woman, and such as would have been thought a beauty in any country in Europe.

After the lieat of the day was over, I went to the governor, Pascoe having previously sent back lis wife to the widow. 'They parted without reluctance, though he declared that she had fallen in love with him at first sight. She was the second wife the old fellow has had since we left Badagry: the first he got at Jannah ; she turned out to be a thief, a jade, and used to get drunk with the king's wives at Katunga, for which I was obliged to order her out of the house; but Pascoe, with tcars in his eyes, begged me to forgive her, as she really loved him, and he loved her. I was not sorry when I heard, the day we left Katunga, that she had walked off with all the coral and other little trinkets which Mrs. Belzoni had given him before le left England, as I trusted it would be a lesson to him in future. I told the governor that the widow was now arrived, and I wished he would send me off according to his promise. He said, he did not know that she had arrived, but would send for her. He again repeated what he had said yesterday, and so did I; to which I added that I should be sorry if such a foolish affair should have any effect on the good understanding that existed between him and me before I went to Boussa. The widow arrived, having stripped off her finery, and put on only a common country cloth around her, and one female slave in attendance. She saluted the governor according to the custom of the country ; that is, by kneeling down on the ground on her knees and elbows, with the palms of her hands before her face. It was some time before the governor spoke: he then began, and gave her a lecture on disobedience and vanity, and asked her where she was going: she said, after some slaves of hers who had run away and gone to Nyffe: with which excuse, after his telling her she did not speak the truth, she was dismissed; and when she got outside the coozie, or hut, she shook the dust from her cloth with the greatest 
contempt. "That," says he, " is a bad woman; none of the sultans like her; she will not pay duty on any thing: but you shall go tomorrow." I went home, determined never to be caught in such a foolish affair in future, as my last journey ought to have taught me never to make friends of the opposition party in any place, for they were always sure to lead to trouble, if not mischief.

As the governor said I should go to-morrow, I took him at his word, and accordingly left Wawa the second time, determined that politics should never bring me back to the place again. We halted at a village of the Cambrie, remained here an hour, then proceeded an hour, and halted at another, where the gentlemen seized a sheep, as they had done at the former place. I gave them a severe lecture, which they listened to very quietly, but killed the sheep, lighted a fire, and roasted it with the skin on, before the poor Cambrie its owner. In the evening I arrived at the ferry, where I had an excellent house, and plenty of presents of sheep, eggs, and honey, sent to me and my friends: the carriers arriving at sunset with the baggage, and living at free quarters on the inhabitants, as they had done on the Cambrie.

Being unwell, I remained at the ferry three days; and on the 10th, about noon, having got all my baggage over, I crossed the Quorra, which at this time was about a quarter of a mile in width, running at the rate of two miles an hour, and in the middle ten or twelve feet deep. The ferry is crossed by canoes of about twenty feet long and two broad. Cattle are occasionally made to swim over.

The four rogues of slaves wanted to cheat me out of my horse, and urgently invited me to pass over first. I told them, when I saw the horses fairly over I would go, but not until then : at which they were evidently much disappointed; and as it was, they succeeded in cheating me out of one which the governor had lent me.

The master of the house in which I lived in Comic, a very Q 2 
respectable man, and formerly head man to the king of Nyffe, but who had fled to escape the civil war, told me that the river was full of rocks and islands nearly the whole way to the sea, which it entered at the town of Fundah; that the people of that country visited the southern parts of Nyffe' ; that the people of Benin came up by land, and had the river to cross, as they never travelled by water if they could avoid it, it being against their fetish; that the river farther down ran more to the eastward, until joined by the river Kadania, flowing from the east, when it turned to the west, and fell into the sea.

I now proceeded on my journey towards Kano, and having travelled about six miles, came to a walled village called Dallu ; and beyond that five miles to El Wata, which appeared to be inhabited by blacksmiths. Though the village was small, I counted, on the way to where I was to lodge, four large blacksmiths' shops with five forges in each. The blacksmiths were very civil to me; they gave me their best house, some corn for my horses, and a goat and some yams.

The natives of Borgoo, of whom I have now taken leave, and to whom the Arabs and their neighbouring nations give such a bad character for theft and robbery, always behaved honestly to me. I never lost the smallest article while amongst them. I have travelled and hunted alone with them, and myself, servants, and baggage, have been at their mercy. I ever found them cheerful, obliging, good-natured, and communicative; and the plundering of the sheep, goats, \&c. from the villages, by the slaves of Yarro and Mohamed of Wawa, was not the act of natives of Borgoo, but of Houssa; as were the four messengers of Wawa, who had also formed a design to plunder me. These persons are nearly halfstarved, and possessed with the idea that it is only right their masters' subjects should feed them when on a journey, as they have no other provision but what they can catch in this manner; 
and therefore all they can lay their hands on is considered by them as good and lawful prize. They are more warlike than any of their neighbours; more bold and independent also : and parties of two or three will infest the roads of the neighbouring kingdoms, and carry off passengers whom they may meet, and sell them as slaves.

The kingdom, as I have already said, is divided into the petty states of Niki, Kiama, Wawa, and Boussa, of which Boussa is considered the head, Niki the next. The governors are all hereditary as long as they can keep their place. These states sometimes make war upon one another, when the sultan of Boussa interferes, and makes both parties pay. The kingdom is bounded on the east by the Quorra; on the south by Yourriba; on the west by Dahomey; and on the north by a large country called Gourma, which they assert to be inhabited by naked savages, but the Mahomedans say by a civilized people, and governed by a powerful sultan. The country is eleven days' journey from north to south, and thirty from east to west: its rivers are the Quorra, Moussa, and Oli: its mountains are the range which passes through Yourriba, Youri, Zamfra, Guari, and Zegzeg. The face of the country is partly plain and partly mountainous, abounding in game of all the kinds common to Africa; and the inhabitants are said to be great hunters. Through Borgoo the caravans from Houssa and Bornou pass to Gonja and Yourriba. 'They have few cattle, but plenty of corn, yams, plantains, and limes. Their religion is paganism, but they offer no human sacrifices.

Tuesday, 11th.-Left El Wata, the country around which is well cultivated. The ant-hills here are the highest I have ever seen, being from fifteen to twenty feet high, resembling so many Gothic cathedrals in miniature. Halted at another walled village to change carriers, which, like El Wata, was also full of blacksmiths. In all the villages I passed through to-day there is a fetish-house, or pagan house of worship, in good repair; showing that the head 
people and the majority of the inhabitants, though pagaus, have a regard for religion. Figures of human beings are painted on these houses, as are also the boa, the alligator, and the tortoise. The country is well cultivated, and planted with corn, and yams, and cotton. They have plenty of sheep and goats, a few small horses, but no cows; and large plantations of bawanas and plantains are seen by the river side. 'The blacksmiths are still in great number's. They get their iron ore from the hills, which they smelt where they dig it, and which is done without mining. The taya paid me a visit, wishing me to remain at this place to-morrow, as an army of the Fellatas were in Koolfu, on their return to Sockatoo. He still shuffles off his bargain, and begged hard that I would remain liere until the day after to-morrow, as the Fellatas would then be gone. I said I had nothing to do with the Fellatas; they would not hurt me : that he had put me off from day to day, always making a fresh bargain, different from the one he had made before. I offered him half the money here, on his giving me proper security; but he began haggling again, and went off without coming to any certain agreement, as he has always done. I however determined to get to Koolfu to-morrow if possible, as these Fellatas are the very people I want to meet, more particularly if they are from Sockatoo.

Wednesday, 12th.- In the afternoon of this day we halted at a village, after crossing a wooden bridge over a stream called the May-yarrow. It was rudely constructed of rough branches covered with earth; long, and so narrow that two horses could not pass at one time. It is the first I lave seen in Africa. I remained here only a few minutes, when I went to another village, where the carriers, after setting the baggage down, ran off. As soon as myself and servants arrived we were instantly surrounded by the whole male population of the village, all armed with bows and arrows, their knives in their hands, and bow-rings on their 
thumbs, perfectly ready for war. I could not help being much amused at their uncalled for alarm; and to prove to them how tranquil I felt, I dismounted from my horse, and sat quietly down on the baggage, ordering my servants to do the same. 'They pretended not to understand a word of the Houssa language; for that they did not understand it was next to impossible, as not a town or village between this and Badagry occurred in which we did not find one or more that could speak that language; and the Boussa messenger not having come up, we could not talk to them in the Nyffé tongue. For a little time silence prevailed, when all at once they seized on the baggage, each man taking something, until the whole was gone. I now re-mounted, with my servants, and followed. They ran along as fast as it was possible for them, and we rode after them; at length we came to another village, where the people understood Houssa, and asked what I wanted. I said, to stop all night. These voluntary carriers however took up the baggage again, and crossing the May-yarrow by a wooden bridge, entered the town of Cabra, which is in fact the same town I had reached, the river dividing it into two parts. Having also crossed, I was taken with my things in front of the head man's house; where they questioned and cross-questioned me as to whether I was going to their king or not; but to none of their questions did I think fit to give a direct answer. When they found I was not disposed to commit myself they carried my things to a house for the night. Here for the first time I had to buy wood, grass, and corn : they always asking, "Where is the money?" before they would give me any thing. I sent Ali off to the chief of the Fellatas, with a letter addressed to Bello, as I find they leave Koolfu at day-break. I therefore missed them by being detained and humbugged on the road, through the manouvres of the taya, who was very anxious I should not see the Fellatas.

'Thursday, 13th. - The whole of this day was spent in expectation 
of my paying a visit to the queen of Nyffé, who is at present residing here; but in the evening I was informed she could not receive me, as the king her husband is absent, at a town called Raba, two days' journey distant ; but that I may see the king's mother in the morning, who will inform me when and how $I$ am to proceed to Kano. During the night thunder, lightning, and rain.

Friday, 14th.-After breakfast I went and visited the queenmother, according to last night's arrangement; I took with me as a present a Chinese crape shawl, part of a string of coral, and a mock gold chain, and some silk. In the outer coozie of her house I found mats spread for me, and a sheep-skin for her majesty. Her male attendants were mostly all old men, without teeth. In this company I remained for near a quarter of an hour. Then came in a number of women past their teens, and seated themselves on the mats opposite to me. They were decently dressed, in short check bed-gowns, the manufacture of the country, with a stuffing in the breast, which made them appear full-breasted. Around their loins they wore striped cotton cloths, which reached down to their ankles. Their woolly hair was dressed in the crest fashion; over which they wore a cap flowered and ornamented with red and white silk; around which there was tied a piece of check, flowered with white silk and fringed at each end, the ends hanging down: this was about the breadth of a broad riband. After sitting in profound silence for some time, they looking at me and I at them ; at last her majesty made her appearance, dressed in a large white tobe or shirt. On her head she wore a coarse green cloth cap with two flaps, and trimmed with red tape. She was old, walked with a staff, and had only one eye. I rose to receive her, and shook her by the hand. She sat down on the sheep-skin, and I on the mat beside her. After asking after her health, and she doing the same, and how I had fared on my journey, I began to display my present before her, told her who I was, and where I wished to go. 
She appeared much gratified with the present, particularly the chain; said I ought to go and see her son the ling, who was only two or three days distant, and he would forward me to where I wished, and be glad to see me. I said I would go with pleasure, but the rains had now set in; and that I wished to proceed on my journey with the taya; that I had a great number of books for Bello, and the Sheik of Bornou, and they would all be spoiled if they got wet; that this country was very sickly in the rains; and that three white men who accompanied me had died already. She said she had sent a messenger to her son the night of my arrival; that he would return to-night or to-morrow morning, and he would bring orders to say whether I was to go to Raba, or not; that if I went, they would detain the taya until my return. I said, "Very well; but I must have a horse, as both mine have sore backs." I then took leave of her majesty, as she is called. A native of Moorzuk, named Mohamed Ben Ahmet, who has long resided in this country, served as my interpreter. He is married to one of the king's daughters; he is styled in Nyffe El Magia. I had the following account from Ben Ahmet: that this woman was the late king of Nyffe's relation; that her son Mohamed El Magia, who is a Mahometan, is fighting with the other, who is called Edrisi and a pagan, for the kingdom; that Mohamed is assisted by the Fellatas, and the other, who has the best right, by the people of Nyffe; that Mohamed has gained every battle this summer, and that there is no doubt of his gaining the day; that there is a cessation of hostilities during the rains; that next summer will decide the fate of Edrisi ; that Mohamed can read and write Arabic; is a great drunkard, but very generous.

Tabra is on the north bank of the river May-yarrow, over which is a narrow wooden bridge, which will not bear a man and horse. This bridge connects it to a part of the town on the other sick the river, which is also surrounded on the three sides by a wall. 
The two parts may contain from eighteen to twenty thousand inhabitants; they are the occasional residence of the Magia, who has a house here; and it is also the place of his birth. His mother during his absence is considered as governor assisted by the sirtain fada, or master of the ceremonies. There appears to be plenty of sheep and goats. and plantations of yams, plantains, calavances, millet, and limes. The river is always full of water, and may be about twenty yards broad, shaded with large trees; the banks rise with a gentle ascent from the river, and are planted with yams, millet, \&c. There are only a few blacksmiths, but a great number of weavers. 'Ihe inhabitants, with a few exceptions, are pagans, and they all, men and women, have the reputation of being great drunkards. The Houssa caravans pass close to the north side of the town, but seldom halt here. It was deserted last year, when Edrisi was driven here with his army; the inhabitants flying to Ingastrie in Youri, and to the province of Wawa; but are now mostly returned.

Sunday, 16 th. - I was visited by the sirtain fada this morning, who had just returned from seeing the Fellatas safe out of Koolfu: he told me that the Benin people, before the civil war began, came here to trade; that the Quorra ran into the sea, behind Benin, at Fundah; that the Nyffe people and those of Benin were the same people; that Benin paid tribute to Nyffe-(this is common with all negroes, to exalt their native country above all others, in their accounts to strangers). He said they got their salt from a town called Affaga, near the sea : this is the Laro or Alaro of Yourriba, and in possession of the Fellatas. In the evening an eunuch, a messenger, arrived from the king, to take me to the Sanson, or gathering-place, where he was; and to stop the taya.

Monday, 17th.-This morning a messenger of the king of Youri arrived, bringing me a present of a camel, to assist in carrying my baggage to Kano. He said the king, before he left Youri, had shown him two books, very large, and printed, that had belonged to the white 
men, that were lost in the boat at Boussa; that he had been offered a hundred and seventy mitgalls of gold for them, by a merchant from Bornou, who had been sent by a Christian on purpose for them. I advised him to tell the king, that lie ought to have sold them; that I would not give five mitgalls for them; but that if he would send them, I would give him an additional present; and that he would be doing an acceptable thing to the king of England by sending them, and that he would not act like a king if he did not. I gave him for his master one of the mock-gold chains, a common sword, and ten yards of silk, and said I would give him a handsome gun and some more silk, if he would send the books. On asking him if there were any books like my journal, which I showed him, he said there was one, but that his master had given it to an Arab merchant ten years ago; but the merchant was killed by the Fellatas on his way to Kano, and what had become of that book afterwards he did not know. He also told me, that the fifteen men whom I had seen at Wawa belonging to Dahomey were slave-merchants ; that they had boughit a hundred slaves at Youri; that they also bought small red beads that came from Tripoli ; that at Wawa they were to get a hundred more slaves, when they would return to Dahomey; that these people bring cloths, earthen ware, brass and pewter dishes, and sell them in Houssa, Nyffe, and Youri, for slaves and beads.

Wednesday, 19th.-Dull and cloudy this morning. 'T'he eun uch came with his horse ready saddled, but without one for me. I told him I was all ready, but would not go until he brought me a horse. He then pretended that he was going, and asked if I had no present to send to the king. I said I had, but should give it myself when I saw him; not until then. He then departed; when a Fellata, calling himself a messenger from Bello, residing with the king, came and said he would make the eunuch stop, and removed my baggage and myself to a good and quiet house, as the one I was in was much disturbed by women and children; and it is settled that 
I am to go with him to the king to-morrow. I have offered two hundred thousand cowries to have my baggage carried, but I cannot even get a letter conveyed to Kano; either so jealous are they of me, or they have an eye to my baggage, about which they have formed anxious conjectures. I had a present from the king's sister of a sheep, for which she modestly requested a dollar and some beads. My new house is very snug and comfortable. I have three rooms for myself and servants, with houses for my horse and mare, an old man and his wife to look after it, and I can keep out all idle per'sons.

'Thursday, 20th.-Morning clear and warm. I had to remain to-day also, as my guide and messenger, the black eunuch, is gone to the Koolfu market again. At sunset he and Omar 'Zurmie (or Omar the Brave), the messenger of Bello, waited on me, and told me that they would leave this for the Sanson, or camp, in the course of the night, if I was ready, and that Zurmie had a horse ready for me. I said I was ready at a moment's notice, and had been the last four days. In the night we had a tornado, with thunder, lightning, and rain.

Friday, 21st. - This morning I left Tabra in company of Omar the Brave, a black eunuch, and Mohamed Ben Ahmet, the Morzukie, as my interpreter and servant; and having travelled twenty-seven miles, came to a village called Kitako, where we passed the night. Saturday, 22d.-At 1.30 A .M. left Kitako. 'The moon through the thick clouds just enabling us, by the assistance of two Amars (spearmen) who went a-head, to thread our way through the thick woods, and over some of the most ticklish wooden bridges that ever man and horse passed over. The morning was raw and cold, and the path slippery and wet. At 4.30 I got so unwell and unable to bear the motion of the horse, that I dismounted, and lay down on the wet ground without covering, or any thing underneath me; for there are times when a man, to get rid of 
his present sickness, will try any remedy, whatever may be the after consequences: this was my case, and I lay until six, when I rose much better of my sickness, but with severe pains in the bones. A short while after starting, I crossed over the wall of a ruined town called Jinne, or Janne, through plantations of indigo and cotton, choked up with weeds. The morning was raw and cloudy. A few of the ragged inhabitants were up; two or three of the most miserable starved horses I ever saw were tied to stakes close to the few huts that were rebuilt, their backs dreadfully lacerated, the skin being nearly off from the shoulder to the rump, and their eyes running with matter. Only for the verdure of the trees at this season, and a beautiful stream of clear water, whose banks were planted with plantain and paln-oil trees, this would have been one of the most miserable scenes I ever saw in my life. After passing the stream twice, without bridges, whose banks were very steep and slippery, with several deep round holes, as man traps, on each side the road, I ascended the plain above, from whence I saw the ruins of several other towns and villages along the banks of the ravine. At eight passed the ruins of another town; and at nine I met, attended by a great rabble, armed with pickaxes, hoes, and hatchets, Mohamed El Magia, or the would-be king, mounted on horseback, and halted under a tree. When they told me there was the Magia waiting to receive me, I rode up and shook hands with him. He asked me after my health, and how I had fared on the road, and then told the eunuch who was with me to take me to his house; he then rode past, as I was informed, to complete the ruin of the last, as I thought already ruined, town I had passed through. He was mounted on a good bay horse, whose saddle was ornamented with pieces of silver and brass; the breastpiece with large silver plates hanging down from it, like what is represented in the prints of Roman and eastern emperor's' horses. He is a tall man, with a sort of stupid expres- 
sion of countenance, having a large mouth and snagged teeth, with which he makes himself look worse when he attempts to smile, and looks indeed like any thing but a king or a soldier. He wore a black velvet cap, with two flaps over the ears, and trimmed with red silk, a blue and white striped tobe, red boots, part of leather and part red cloth, in rags; in his hand lie had a black staff, with a silver head; his slaves were carrying a const-made umbrella and his sword. I paid him every decent respect, and put on as many smiles as I was able, as I know that those ragged and dirty rogues, when they have power, have more pride than a real king, and expect a great deal more respect, and cannot bear a man to look serious. At ten I arrived at the Sanson, or camp, where I was lodged in the eunuchs' part, having a small unoccupied hut separated from the rest allotted for me to live in. Here I was left to myself until 3 P. M., when the eunuch came and told me the king had arrived, and wished to see me. I went directly, taking a present, which I displayed before him. When the articles were taken away by an eunuch, I told him who and what I was, where I was going, and that I wanted his assistance and protection to the governors of Guari or Zegzeg, in Houssa; that I had been well treated by every king and governor between Badagry on the sea-coast, to Tabra in his dominions, and I hoped for the same favourable reception from him. He said it was easy to do all that $I$ had asked, and he would do it.

Sunday, 23d._-This morning I was much better, having shut my little straw hut up as close as possible, so that I was as if in a steam bath all night. . I have ever found this and fasting a good cure for most disorders.

The king went through the camp, attended by a great rabble, a slave carrying the umbrella I had given him over his head. He paid me a visit, and began, as soon as he had seated himself, to show me his staff of authority, a black stick, about four feet long, 
with a silver head. He said I had got some of the same kind, and he wanted one. I said I could not indulge him with one, unless I gave him that intended for Bello. He then begged my travelling knife and fork. I said, "What, then, I am to go without, and eat with my fingers! he had better go to Tabra, and take all I had." He observed he would certainly not do that ; that he would send me to Kano, and that I should go in five or six days after this. He then went home, and sent me, as a present, a small country horse, which will do well enough for Pascoe to ride. I have now two horses and a mare.

The Sanson, or camp, is like a large square village, built of small bee-hive-like huts, thatched with straw, having four large broad streets, and with a square or clear place near the huts of the king. Only for the number of horses feeding, and some picketed near the huts, and the men all going armed, and numbers of drums beating, it would pass for a well-inhabited village. Here are to be seen weavers, taylors, women spinning cotton, others reeling off, some selling foo-foo and accassons, others crying yams and paste, little markets at every green tree, holy men counting their beads, and dissolute slaves drinking roa bum.

Monday, 24th.- Morning cool and cloudy. In the early part of the morning I went to take leave of the king, whom I found in his hut, surrounded by Fellatas, one of whom was reading the Koran aloud for the benefit of the whole; the meaning of which not one of them understood, not even the reader. This may seem odd to an Englishman; but it is very common for a man, both in Bornou and Houssa, to be able to read the Koran fluently, and not understand a word in it but "Allah," or able to read any other book. They left off reading when I came in; and as soon as the compliments of the morning were over, the king begged me to give him my sword, which I flatly refused, but promised to give him the five dollars, the staff, and the pistol, whenever I was 
permitted to leave this for Kano, which he promised I should do, and pointed out a person whom he said he would send with me as a messenger; and that a merchant from Koolfu would come and agree about the price he was to have for carrying my baggge. I thanked him, and took my leave. He is one of the most beggarly rogues I have yet met with; every thing he saw or heard that I was possessed of he begged, not like a person that wished to have them because they were scarce or rare, but with a mean greediness that was disgusting. Though I had given him a better present than he had ever got in his life before, he told me that I said "No, no," to every thing he asked for. He has been the ruin of his country by his unnatural ambition, and by calling in the Fellatas, who will remove him out of the way the moment he is of no more use to them; even now he dares not move without their permission. It is said that he has put to death his brother and two of his sons. Through him the greater part of the industrious population of Nyffé have either been killed, sold as slaves, or fled from their native country. To remove him now would be charity; and the sooner the better for his country.

At 8.30 in the morning I left the Sanson, and riding on ahead of old Malam Fama, the Morzukie, I halted under a tree at eleven to let the horses feed, and the Malam to come up with the sheep. At noon, Mahomed having joined, I started with a plundering party who were going the same road. They told me they were going to seize some villagers who had returned to build up their ruined huts and sow a little millet without first praying for leave to the Magia. On crossing one of the small rivers and ascending the steep and slippery bank, the chief of this band checked his horse, and both horse and rider fell souse into the water. He was close behind me, but I left his companions to pick him up. On the 25th we once more reached 'Tabra.

I have observed more people with bad teeth and the loss of 
the front teeth in Nyffe than any other country in Africa, or indeed any other country. 'The males mostly are those who lose their teetl. Whether it may arise from the universal custom of chewing snuff mixed with natron or not, I do not pretend to say. The white of the eye in the black population is in general bilious-looking and bloodshot. 'There is scarcely one exception, unless it be in those below eighteen or twenty years of age.

'Tuesday, May 2.- This morning I left Tabra, and travelling along the banks of the May-yarrow, passed the walled village of Gonda. Having crossed a stream coming from the north, and running into the May-yarrow, I entered the walled town of Koolfu, the greatest market town in this portion of Nyffé, and resorted to by trading people from all parts of the interior. I was provided with a good house; and the head man of the town, a plausible fellow, was very officious, but at the same time giving broad hints for a present. Mohamed Kalu, the madagoo or head man of the goffle from Bornou, has to remain here until after the Rhamadan. I was visited by all the principal people in the place, as a matter of curiosity, though many of them had seen me at Tabra.

Monday, 8th.-Clear and cool. The house in which I live is one of the best in Koolfu. I have three separate coozies parted off from the rest of the house, and a place for my stud, which now amounts to two horses and a mare. My landlady is a widow, large, fat, and deaf, with an only child, a daughter, about five years old; a spoiled child. 'The widow Laddie, as she is called, is considered to be very rich. She is a merchant; sells salt, natron, and various other articles: but what she is most famed for is her booza and roa bum, as the palm wine is called; and every night the large outer liut is filled with the topers of Koolfu, who are provided with music as well as drink, and keep it up generally until the dawn of morning separates them. Their music consists of the drum, erbab, or guitar of the Arabs, the Nyffe harp, and the voice. 
Their songs are mostly extempore, and allude to the company present. The booza is made from a mixture of doura, or Guinea corn, honey, Chili pepper, the root of a coarse grass on which the cattle feed, and a proportion of water: these are thrown in equal proportions into large earthen jars, open at top, and are allowed to ferment near a slow fire for four or five days, when the booza is fit to drink, and is put into earthen jars. It is a very fiery and intoxicating beverage; but, whether Mohamedan or pagan, they all drink, and agree very well together when in their cups. At first neither I nor my servants could sleep for their noise, but now I have got used to it. This night the new moon was seen, and Mohamedan and pagan joined in the cry of joy. My landlady had thirteen pieces of wood, on each of which was written by the Bornou malem the word "Bismillah," the only word he could write. These boards she then washed and drank the water, and gave to her family to drink. She offered some of it to me; but I said I never drank dirty water: and I thought that if she and her servants had taken a comfortable cup of booza or bum it would have done them more good than drinking the washings of a board written over with ink; for the man was a rogue who had made her pay for such stuff. "What!" says she, "do you call the name of God dirty water? it was good to take it." These rogues, who call themselves malems, impose on the poor ignorant people very much; and the pagans are as fond of having these charms as the Mohamedans. 'These dirty draughts are a cure for all evils, present and to come, and are called by the people dua. Some of their fighting men will confine themselves to their houses for thirty or forty days, fasting during the day, and only drinking and washing with this dirty stuff. If a man is fortunate, or does any feat above the common, it is attributed to the dua, or medicine : neither his wit nor the grace of God gains a man any thing. Tuesday, 9th.-Clear and warm. The new moon having been 
seen last night put an end to the fast of the Rhamadan; and this day is kept throughout the northern interior by Mohamedan and Kafir. Every one was dressed in his best, paying and receiving visits, giving and receiving presents, parading the streets with horns, guitars, and flutes; groups of men and women seated under the shade at their doors, or under shady trees, drinking roa bum or booza. I also had my share of visitors: the head man of the town came to drink hot water, as they call my tea. The chief of Ingaskie, the second town in Youri, only a day's journey distant, sent me a present of a sheep, some rice, and a thousand gora nuts, for which he expects double the amount in return. The women were dressed and painted to the height of $\mathrm{Nyffe}$ perfection; and the young and modest on this day would come up and salute the men as if old acquaintances, and bid them joy on the day; with the wool on their heads dressed, plaited, and dyed with indigo; their eyebrows painted with indigo, the eyelashes with khol, the lips stained yellow, the teeth red, and their feet and hands stained with henna; their finest and gayest clothes on; all their finest beads on their necks; their arms and legs adorned with bracelets of glass, brass, and silver, their fingers with rings of brass, pewter, silver, and copper; some had Spanish dollars soldered on the back of the rings. They, too, drank of the booza and roa bum as freely as the men, joining in their songs, whether good or bad. In the afternoon, parties of men were seen dancing: free men and slaves all were alike; not a clouded brow was to be seen in Koolfu: but at nine in the evening the scene was changed from joy and gladness to terror and dismay; a tornado had just began, and the hum of voices and the din of people putting their things under cover from the approaching storm had ceased at once. All was silent as death, except the thunder and the wind. The clouded sky appeared as if on fire ; each cloud rolling towards us as a sea of flame, and only surpassed in grandeur and brightness 
by the forked lightning, which constantly seemed to ascend and descend from what was now evidently the town of Bali on fire, only a short distance outside the walls of Koolfu. When this was extinguished a new scene began, if possible worse than the first. The wind had increased to a hurricane ; houses were blown down; roofs of houses going along with the wind like chaff, the shady trees in the town bending and breaking; and, in the intervals between the roaring of the thunder, nothing heard but the war-cry of the men and the screams of women and children, as no one knew but that an enemy was at hand, and that we should every instant share in the fate of Bali. I had the fire-arms loaded when I learned this, and stationed Richard and Pascoe at the door of each hut, and took the command of my landlady's house, securing the outer door, and putting all the fires out. One old woman roasting ground nuts, quite unconcerned, made as much noise as if she had been going to be put to death when the water was thrown over her fire. At last the rain fell: the fire in Bali had ceased by its being wholly burnt down. In our house we escaped with the roof blown off one coozic, and a shed blown down. All was now quiet; and I went to rest with that satisfaction every man feels when his neighbour's house is burnt down and his own, thank God! has escaped.

Sunday, 14th.-Mohamed, the Fezzanie, whom I had hired at Tabra, and whom I had sent to the chief of Youri for the books and papers of the late Mungo Park, returned, bringing me a letter from that person, which contained the following account of the death of that unfortunate traveller: that not the least injury was done to him at Youri, or by the people of that country; that the people of Boussa had killed them, and taken all their riches; that the books in his possession were given him by the Imam of Boussa ; that they were lying on the top of the goods in the boat when she was taken; that not a soul was left alive belonging to the boat; that the bodies of two black men were found in the boat chained 
together; that the white men jumped overboard; that the boat was made of two canoes joined fast together, with an awning or roof behind; that he, the sultan, had a gun, double-barrelled, and a sword, and two books that had belonged to those in the boat; that he would give me the books whenever I went to Youri myself for them, not until then.

Monday, 15th.-I am still very weak; Richard worse. I had a letter from the learned Abdurahman, of Kora, a noted chief of banditti, and who once, with his followers, overran Nyffé, and held possession of the capital six months. He now keeps the town of Kora, a day's journey to the north-east, and is much feared by Mohamedan and Kafir. He is a native of Nyffé. He is particularly anxious that $I$ should visit him, as he wants my acquaintance, and begs I will give him the Psalms of David in Arabic, which he hear's I have got. His letter was written on part of the picture of the frontispiece of an European book, apparently Spanish or Portuguese. He says he has something to communicate to me, which cannot be done but by a personal interview; but unless he come to Koolfu I told his messenger, I could not see him.

'Tuesday, 23d.-Cool and cloudy. A large caravan arrived from Yourriba. They had come through Borgoo, where they sold what natron they had remaining after they left Yourriba. They were in Katunga when I was there ; but were forbidden to hold any communication with us, on pain of having their throats cut. They told me that my friend the fat eunuch had endeavoured to hire a man to assassinate me, but that they were all afraid. There are strong reports of a war between the Sheik El Kanami and the Fellatas. They say the sheik has taken the city of Hadija, and that the governor of Kano is gone out to meet him, as he is advancing upon Kano. Whether it is a report to please the Nyffé people, who cannot bear the Fellatas, or not, I do not know. We had a number of such reports when in Bornou last journey. In the evening a messenger 
from the sultan of Boussa arrived, bringing me a present of a beautiful little mare. The messenger of the sultan was accompanied by another person from the midaki, a female slave, bringing me rice, yams, and butter. He brought a message from the sultan desiring me to kill a she-goat, and distribute the flesh amongst the inhabitants of Koolfu the day before I left it ; that he had distributed gora nuts and salt for me at Boussa, which would do for Koolfu. I was also desired not to eat any meat that came cooked from the west, and which would be sent by the Magia's female relations from Tabra, as they intended to take away my life by poison. Through the night continual rain, thunder, and lightning.

Thursday, 25th.-Sent Sheeref Mohamed to Raba, a town possessed by the Fellatas, three days south of this, on the banks of the Quorra, with a message to the late Imam of Boussa, who, he says, has got some of the books belonging to the late Mungo Park: one, he tells me, was carried to Yourriba by a Fellata, as a charm and preservative against musket balls. He is either to buy them, or I will give him Arabic books for them in exchange.

Friday, June 17th.-This evening I was talking with a man that is married to one of my landlady's female slaves, called her daughter, about the manners of the Cumbrie and about England; when he gave the following account of the death of Park and his companions, of which he was an eye-witness: He said that when the boat came down the river, it happened unfortunately just at the time that the Fellatas first rose in arms, and were ravaging Goober and Zamfra; that the sultan of Boussa, on hearing that the persons in the boat were white men, and that the boat was different from any that had ever been seen before, as she had a house at one end, called his people together from the neighbouring towns, attacked and killed them, not doubting that they were the advance guard of the Fellata army then ravaging Soudan, under the command of Malem Danfodio, the father of the present Bello; that 
one of the white men was a tall man with long hair; that they fought for three days before they were all killed; that the people in the neighbourhood were very much alarmed, and great numbers fled to Nyffé and other countries, thinking that the Fellatas were certainly coming among them. The number of persons in the boat was only four, two white men and two blacks: that they found great treasure in the boat; but that the people had all died who eat of the meat that was found in her. This account I believe to be the most correct of all that I have yet got; and was told without my putting any questions, or showing any eagerness for him to go on with his story. I was often puzzled to think, after the kindness I had received at Boussa, what could have caused such a change in the minds of these people in the course of twenty years, and of their different treatment of two European travellers. I was even disposed at times to flatter myself that there was something in me that belonged to nobody else, to make them treat me and my people with so much kindness; for the friendship of the king of Boussa I consider as my only protection in this country.

Koolfu, or, as it is called by many, Koolfie, is the principal town for trade in Nyffé at present; and at all times a central point for trade in this part of the interior. It is situated on the north bank of the river May-yarrow; and it is surrounded by a clay wall about twenty feet high, and has four gates. It is built in the form of an oblong square, having its longest diameter from east to west; there is a long irregular street runs through it, from which lead a number of smaller streets. There are two large open spaces near the east and west ends of the town, in which are booths, and large shady trees, to protect the people from the heat of the sun, when attending the markets, which are daily held in those places: there are, besides the daily markets, two weekly markets on Mondays and Saturdays, which are resorted to by traders and people inhabiting the sea coast. Ajoolly and the other towns in 
Yourriba, Cubbi, Youri, Borgoo, Sockatoo, and Zamfra on the north, Bornou and Houssa on the east, and, before the civil war, people from Benin, Jabbo, and the southern parts of $\mathrm{N}_{\mathrm{y} f f e}$, used to resort to this town as a central point of trade, where the natives of the different countries were sure to get a ready sale for their goods ; either selling them for cowries, or exchanging them for others by way of barter. Those who sold their goods for cowries attend the narket daily, and when they have completed their sale, buy at once the goods or wares they want, and return home. Such is the way of the small traders, who are nine out of ten women, and are principally from the west part of the Quorra, even as far off as Niki : they carry their goods on their heads in packages, from sixty to eighty and a liundred pounds weight. The goods these people bring from the west are principally salt, and cloths worn by the women round their loins, of about six yards in length and two in breadth, made of the narrow striped cloth, in which red silk is generally woven, and a great deal of blue cotton ; this is called Azane, and the best are worth about three thousand to five thousand cowries, or two dollars:- Jabbo cloths, which are about the same length as the others, and about the breadth of our sail-cloth, are worn by slaves, and have a stripe or two of blue in them; the poor classes also wear them, men and women :-Peppers, called monsoura, shitta, and kimba; monsoura is like our East India pepper; shitta is the malagetta pepper of the coast; kimba is a small thin pepper, growing on a bush, near the sea coast, in Yourriba, of a red colour, like Chili pepper :-Red wood from Benin, which is pounded to a powder and made into a paste; women and children are rubbed with this, mixed with a little grease, every morning; and very frequently a woman is to be seen with a large score of it on her face, arms, or some part of her body, as a cure for some imaginary pain or other :A small quantity of calico or red cloth is sometimes brought, which is of European manufacture. They take back principally natron, 
beads made at Venice of various kinds, and come by the way of 'Tripoli and Gliadamis, and unwrought silk of various colours, principally red, of about one ounce in weight, and is sold here at three thousand cowries; it and natron are as good as cowries.

The caravans from Bornou and Houssa, which always halt here a considerable time, bring horses, natron, unwrought silk, beads, silk cords, swords that once belonged to Malta, exchanged for bullocks at Bengazie, in the regency of Tripoli, sent to Kano and remounted, and then sold all over the desert and the interior; these swords will sell for ten or twenty dollars a piece or that value, and sometimes more; cloths made up in the Moorish fashion; looking-glasses of Italian manufacture from about a penny a piece to a shilling in Malta; tobes or large shirts undyed, made in Bornou; khol or lead used as blacking for the eye-lids; a small quantity of ottar of roses, much adulterated; sweet smelling gum from Mecca; a scented wood also from the East; silks the manufacture of Egypt ; turbans; red Moorish caps with blue silk tassels ; and sometimes a few tunics of checked silk and linen made in Egypt : the last are generally brought by Arabs. A number of slaves are also brought from Houssa and Bornou, who are either sold here or go further on. 'The Bornou caravans never go further than this place, though generally some of their number accompany the Houssa merchants to Agolly in Yourriba, Gonja, and Borgoo, from which they bring Kolla or Gora nuts, cloth of woollen, printed cottons, brass and pewter dishes, earthenware, a few muskets, a little gold, and the wares mentioned before as brought from Yourriba. 'They carry their goods on bullocks, asses, and mules; and a great number of fine women hire themselves to carry loads on their heads; their slaves, male and female, are also loaded. 'I'he Bornou mercliants, during their stay, stop in the town in the houses of their friends or acquaintances, and give them a small present on their arrival and departure, for the use 
of the house. 'The Houssa merchants stop outside the walls in little straw huts or leathern tents, which they erect themselves. They sell their goods and wares in their houses or tents; the small wares they send to the market and round to the different houses by their slaves to sell; there are also a number of male and female brokers in the town, whom they also intrust. 'I'he pedlers or western merchants always live in the houses of the town, and attend the markets daily, employing their spare time in spinning cotton, which they provide themselves with on their arrival, and support themselves by this kind of labour. There have been no fewer than twenty-one of these mercantile women living in my landlady's house at one time, all of them from Yourriba and Borgoo: these women attend the markets at the different towns between this and their homes, buying and selling as they go along. 'The caravans from Cubbi, Youri, and Zamfra, bring principally slaves and salt, which they exchange for natron, Gora nuts, leads, horses, tobes dyed of a dark blue, having a glossy and coppery tinge. The slaves intended for sale are confined in the house, mostly in irons, and are seldom allowed to go out of it, except to the well or river every morning to wash; they are strictly guarded on a journey, and chained neck to neck; or else tied neck to neck in a long rope of raw hide, and carry loads on their heads consisting of their master's goods, or his household stuff; these loads generally from fifty to sixty pounds weight, A stranger may remain a long time in a town without seeing any of the slaves, except by accident, or making particular inquiry. 'The duties which traders pay here are collected by the people of 'Tabra, who take twenty cowries from every loaded person, forty for an ass, and fifty for a loaded bullock.

The inliabitants may amount to from twelve to fifteen thousand, including all classes, the slave and the free; they are mostly employed in buying and selling, though there are a great number of 
dyers, tailors, blacksmiths, and weavers, yet all these are engaged in buying and selling; few of these descriptions ever go on distant journeys to trade, and still fewer attend the wars, except it be to buy slaves from the conquerors. I have seen slaves exposed for sale here, the aged, infirm, and the idiot, also children at the breast, whose mothers had either fled, died, or been put to death. The domestic slaves are looked upon almost as the children of the family, and if they behave well, humancly treated: the males are often freed, and the females given in marriage to freemen, at other times to the male domestic slaves of the family; when such is the case a house is given to them, and if he be a mechanic, he lives in the town, and works at his trade; if not, in the country, giving his owner part of the produce, if not made free; in both cases they always look upon the head of such owner's family as their lord, and call him or her father or mother.

'The food of the free and the slave is nearly the same; perhaps the master or mistress may have a little fat flesh, fish, or fowl, more than their slaves, and his meat is served in a separate place and dish; but the greatest man or woman in the country is not ashamed at times to let their slaves eat out of the same dish, but a woman is never allowed to eat with a man. Their food consists of ground maize, made into puddings or loaves, and about half a pound each, sold at five cowries each in the market; of flummery, or, as they call it in Scotland, sowens, made from the ground millet, which is allowed to stand covered with water, until it gets a little sour ; it is then well stirred and strained through a strainer of basketwork into another vessel, when it is left to settle, and the water being strained off, it is dried in the sun; when perfectly dry, it is broken into lumps and kept in a sack or basket; when used it is put into boiling water, and well stirred, until of a sufficient thickness ; this makes a very pleasant and healthy breakfast with a little honey or salt, and is sold in the market at two cowries a pint every 
morning, and is called Koko. They have a pudding made of ground millet, boiled in the ley of wood ashes, which gives a red colour ; this is always eaten with fat or stewed meat, fish, or fowl. They always stew or grill their meat: when we have it in any quantity it is half grilled and smoked, to preserve until it is wanted to be used. Boiled beans made up in papers of a pound or a half pound each, and wrapped in leaves, sold for two cowries each, and called waki. Beans dried in the sun sold at one cowrie a handful. Small balls of boiled rice, mixed with rice flower, called Dundakaria, a cowrie a piece, mixed with water, and serves as meat and drink. Small balls of rice, mixed with honey and pepper, called Bakaroo, sold at five cowries each. Small balls made from bean flowers, fried in fat, like a bunch of grapes. 'Their intoxicating draughts are the palm wine called roa bum, bouza, and aquadent, very much adulterated and mixed with pepper.

At daylight the whole household arise: the women begin to clean the house, the men to wash from head to foot; the women and children are then washed in water, in which the leaf of a bush has been boiled called Bambarnia: when this is done, breakfast of cocoa is served out, every one having their separate dish, the women and children eating together. After breakfast the women and children rub themselves over with the pounded red wood and a little grease, which lightens the darkness of the black skin. A score or patch of the red powder is put on some place where it will show to the best advantage. 'The eyes are blacked with khol. 'The mistress and the better looking females stain their teeth and the inside of the lips of a yellow colour with gora, the Hower of the tobacco plant, and the bark of a root: the outer part of the lips, hair, and eye-brows, are stained with shuni, or prepared indigo. Then the women who attend the market prepare their wares for sale, and when ready go. 'The elderly women prepare, clean, and spin cotton at home and cook the victuals; the younger 
females are generally sent round the town selling the small rice balls, fried beans, \&c. and bringing a supply of water for the day. The master of the house generally takes a walk to the market, or sits in the shade at the door of his house, hearing the news, or speaking of the price of natron or other goods. 'The weavers are daily employed at their trade; some are sent to cut wood, and bring it to market; others to bring grass for the horses that may belong to the house, or to take to the market to sell; numbers, at the beginning of the rainy season, are employed in clearing the ground for sowing the maize and millet; some are sent on distant journeys to buy and sell for their master or mistress, and very rarely betray their trust. About noon they return home, when all have a mess of the pudding called waki, or boiled beans, and about two or three in the afternoon they return to their different employments, on which they remain until near sunset, when they count their gains to their master or mistress, who receives it, and puts it carefully away in their strong room. They then have a meal of pudding and a little fat or stew. The mistress of the house, when she goes to rest, has her feet put into a cold poultice of the pounded henna leaves. The young then go to dance and play, if it is moonlight, and the old to lounge and converse in the open square of the house, or in the outer coozie, where they remain until the cool of the night, or till the approach of morning drives them into shelter.

Their marriages are the same amongst the Mohamedans as they are in other countries, where they profess that faith. The pagan part first agree to go together, giving the father and mother a present, and, if rich, the present is sent with music, each separate article being borne on the head of a female slave. 'The Mohamedans bury in the same manner as they do in other parts of the world. The pagans dig a round hole like a well, about six feet 
deep, sometimes in the house, sometimes in the threshold of the door, and sometimes in the woods : the corpse is placed in a sitting posture, with the wrists tied round the neck, the liams and legs close to the body: a hole is left at the mouth of the grave, and the relations and acquaintances leave tobes, cloth, and other articles at the small round hole, and telling the dead persons to give this to so and so: these things are always removed before the morning by the priest. The majority of the inhabitants of Koolfu profess to be Mahometans, the rest Pagans, whose modle of worship I never could learn, except that they, like the inhabitants of the other towns in Nyffe, attended once a year in one of the southern provinces, where there was a high hill, on which they sacrificed a black bull, a black sheep, and a black dog. The figures on their houses of worship are much the same as in Yourriba: the lizard, crocodile, the tortoise, and the boa-serpent, with sometimes men and women. Their language is a dialect of the Yourriba, but the Houssa tongue is the language of the market. Their houses and court are kept very clean, as also the court-yard, which is sprinkled every morning with water, having the shell of the bean of the mitta tree boiled in it, which stains it of a dark brown colour; and each side of the doors of the coozies or huts are stained with indigo and ornamented with figures. The women have the stone for grinding the corn, pepper, \&c. raised on a clay bench inside the house, so that they can stand upright while they grind the corn; an improvement to be seen in no other part of the interior, or in Fezzan, the women having to sit on their knees when grinding corn. Their gourd dishes are also of the first order for cleanliness, neatness, and good carving and staining, as also their mats, straw bags, and baskets.

They are civil, but the truth is not in them, and to be detected in a lie is not the smallest disgrace, it only causes a laugh. They are also great cheats. The men drink very hard, even the Maho- 
metans; and the women are generally of easy virtue. Notwithstanding all this against them, they are a people of a natural good disposition; for when it is considered that they have been twice burnt out of the town by the enemy within the last six years, and that they have had a civil war desolating the country for the last seven years, and been subject to the inroads of the Fellatas during twenty years, and having neither established law nor government but what a present sense of right and wrong dictates, I am surprised that they are as good as they are.

I witnessed while here several acts of real kindness and goodness of heart to one another. When the town of Bali was burnt down, every person sent next day what they could spare of their goods, to assist the unfortunate inhabitants. My landlady, who has given away a number of her female slaves to freemen for wives, looks upon them as her own children, attending them when sick; and one who had a child while I was here, at the giving it a name, she sent seventy different dishes of meat, corn, and drink, to assist at the feast on that occasion. In all my dealings with them they tried and succeeded in cheating me, but they had an idea that I was possessed of inexhaustible riches; and besides, I differed with them in colour, in dress, in religion, and in my manner of living. I was considered therefore as a pigeon for them to pluck. Had they been rogues, indeed, they might have taken all I had; but, on the contrary, I never had an article stolen, and was even treated with the most perfect respect and civility they were masters of.

I believe it is generally considered in England, that when a negro slave is attached to his master, he will part with his life for him. Instances of this kind are not so common as they ought to be, when it is considered that all of these slaves are brought up from their childhood, and know no other parent or protector; and if they were to run away, or behave so ill as to cause him to sell them, 
they would never be so well off as they were before. 'I hose who are taken when grown-up men or women, and even boys and girls, run whenever an opportunity offers, and, whenever they can, take their owner's goods or cattle to assist them on their journey. Instances of this kind happened every night.

They have very few bullocks, sheep, or goats, in the country; but that is owing to the desolating war. Corn they have in abundance, as that cannot be driven away by plundering parties. The surrounding country is a level plain, well cultivated, and studded with little walled towns and villages, along the banks of the Mayyarrow, and another little river running into it from the north. It is subject to the Majia, but never visited by him or his people, except to attend the market, or collect the duties from the traders. The town of Kufu, at a short distance (not a mile), has a quarrel with another little town about half a mile from it, called Lajo, the latter having taken the wife of a man, whom they thought they had killed and left for dead, and selling her; hence arose a regular system of retaliation; and they take and sell one another whenever they have an opportunity. Every other night almost the war-cry was raised about stealing asses, oxen, or murder; and sometimes the inhabitants of Koolfu would join in the fray, always siding with Kufu.

Monday, 19th.-Having been detained thus long at Koolfu, by my own and my servant Richard's illness, we left it this morning, accompanied by the head man and the principal inhabitants of Koolfu, who went with me as far as the walled and warlike village of Kufu, where I stopped for the night. Here the head man of Koolfu introduced me to the head man of Kufu, who provided me with a good house, and made me a present of a sheep and some cooked meat. I had also presents of meat sent me by the principal inhabitants. The people of Kufu, not satisfied with having frequently 
seen me and my servants at Koolfu, are in the habit of mounting some trees growing on a small hill close to and overlooking my house and court-yard, to get another and a last look: party came after party until sunset, when they went away.

My landlady, the widow Laddie, also accompanied me to Kufu, where she remained all night. I thought it had been out of a great regard for me; but I was soon let into the secret, by five of her slaves arriving with booza and bum, which she began selling in my court-yard to the different merchants, bullock-drivers, and slaves assembled here, who are going to the eastward.

The village of Kufu is walled, and only about two musket shots from the other walled village, which is to the south, and with whom they are at heavy war. The space between is generally occupied by the caravans bound to the eastward, who usually halt here for a week to complete their purchases at the market of Koolfu before they start. The country around has a rich and clay soil, planted with indigo, cotton, Indian corn, and yams.

Tuesday, 20th. - Having given the head man of Kufu thirty Gora nuts, with which he was well pleased, and loaded the bullocks, horse, ass, and camel, at $6 \mathrm{~A}$. M. left Kufu. The path, or road, through a woody country: the trees consisting mostly of the miradania, or butter tree, which does not grow to a large size; the largest only about the size of our apple trees in Europe, and this only seldom: their girth is not above two or three feet. The path was winding; the soil a deep red clay, covered with a thin layer of sand.

Wednesday, 21st.-After passing a great number of towns and villages, we arrived at a walled town called Bullabulla, where we encamped outside. As soon as my tent was pitched, I was surrounded by the inhabitants. They were quite amused with my hat; and the women soon found that I was a stranger, and no Moslem, and charged me three times as much for any thing I 
wanted to buy as they would any body else. They brought boiled beans, fowls, pudding, goats, sheep, wood, and water, for sale. The young men were dressed in a very fanciful manner, with a bandeau of beads, red and white; the wool cut short, and shaved in circles and straight lines; round the neck strings of red and white beads, with pendants of white beads attached to the lowest string, and reaching to the upper part of the breast; round the loins a tanned sheep or goat's skin, cut into thongs, to the ends of which were attached beads or cowrie shells. Those who pretended to be Mahometans wore a tobe or large loose shirt; but these were few in number, not more than two or three.

The young women wore a string of large beads round the loins; where they had not beads they had pieces of bone, round which was twisted a piece of narrow brown or blue cloth; the beads, bone, or cloth, showing alternately, and hanging down about a foot before and behind, fringed at the end, with cowries or beads attached to the ends of the fringe. They appeared a good looking active set of people, but suspicious. Every two or three women had an armed man to attend them, and to see that they got paid for what they sold. By all accounts they are very ill used, both by their rulers and those who are not. 'Their wives and children are stolen and made slaves by every one who can seize them; and rulers, whenever a demand is made on them, take them by force and sell them as slaves.

Thursday, 22d.-Left Bullabulla, and travelled through plantations of grain, indigo, and cotton; the soil and clay mixed with sand, and here and there large blocks of sandstone, in which were nodules of iron, and veins of clay ironstone ; the face of the country diversified with hills and dales; some of the hills to the south rising into table-topped mounts; the country open and clear; every thing at this season looking green and gay. Halted at the walled town of Rajadawa, the head man of which wished me to stop in the 
town, but I preferred halting outside. He sent me a present of cooked meat, rice, and honey. I gave him in return three yards of silk, a pair of scissors, and fifty Gora nuts. At this town they take, for the chief of Youri, from every loaded bullock 500 cowries, and from every loaded ass 300 cowries. The inhabitants are Cumbrie and pagans, except the head man and about a dozen others, who profess to be Mahometans. They say the governor, like his master of Youri, is a great rogue; and invites people within his walls to detain them, and screw as much out of them as he can. Rajadawa is walled (a clay wall and ditch), and may contain from 6000 to 7000 inhabitants. The environs are clear of wood, and planted with grain, yams, gaza (a kind of potatoe, yellow inside, and very watery, leaving an unpleasant taste in the mouth after eating), indigo, and cotton. We had a plentiful market in the camp. The principal articles for sale were raw bullocks' flesh, fowls, millet, boiled yams, pudding, \&c.

At noon on the 24th, after passing numerous villages, we arrived at the town of Wazo, or Wazawo, the first town in the province of Kotongkora, where the merchants had to pay 250 cowries for every loaded ass, bullock, horse, or mule: of course I passed free, being a white man, and went through the town with my baggage, and encamped about a mile to the eastward of the town. The town of Wazo is built on the shelving side of a rocky mount: on the south-east side is a wall with two gates; the steep sides of the mountain serving as a wall on the other side. The inhabitants are all Cumbrie and pagans; and to-day they are holding a festival, so that we can get nothing to buy. After my tent was pitched, I engaged one of the natives for a few cowries to accompany me to hunt. I saw very little game, except five antelopes, out of gunshot. On my return to the tent I found the head man of Wazo had sent me one fowl, and some millet for the horses, for which he expects nine or ten times the value in return. 'The value of his 
present altogether, at the highest price, is not above 200 cowries. I had to make my dinner of raw flour, water, and an onion, reserving the fowl for my sick servant. During the night heavy rain, but without thunder or lightning.

Monday, 26th.-Morning dull and cloudy. The chief servant of Wazo's head man came to my tent early in the morning in a great fright, saying his master was going to hang him, as he thought he had stole part of the present I had sent him. He said he wished that Moussa or myself would go into the town and bear witness that he had delivered all I gave him. I thought it was only a trick to cause further delay, or to catch something else; I therefore sent Moussa, and on his return had the bullocks loaded; and at 9. 30 A. M. left the place of our encampment near Wazo. Our path was rocky and very winding, having high rocky mounts to the east, with steep perpendicular sides, the tops of most occupied by villages and little walled towns. The inhabitants came into the valleys with millet, boiled beans, yams, and cashew nuts, \&c. to sell; the sellers were all women, every two or three having an armed male protector. In a narrow pass in the valley, as I had lingered behind the caravan, I fell in with a very interesting group, consisting of about a dozen of the natives, all young men, gaily dressed in their beads and tasselled skins, armed with bows and arrows and a light spear, some sitting and others standing; in the midst of them were three Fitakies, and a jackass without a load. The north side of the pass was formed by a high mount, rising perpendicular for about thirty feet above the path, over which hung trees, and on the top of the mount a little village, to which the young men belonged; the south side was formed by a large block of granite, on which the party were seated, the Fitakies looking as grave as the poor ass. At first I thought it was a robbery, and began to prepare my gun, but as I drew close and inquired what was the matter, before I intencled to fire, it proved to be the 
Fitakies selling a sick jackass, which was unable to carry its load to the natives, to kill for food, as they consider its flesh as medicine, and good for coughs and pains in the chest. At noon arrived at the town of Wazo, which is situated in a narrow part of the valley, partly built on the shelving side of a mountain, which forms the south side of the pass and valley, the other part of the town and wall, on the north side; here the Fitakies had to pay ninety cowries for each loaded ass or bullock; I, of course, passed without payment. After passing Worm, or Wormzou, as it is sometimes called, the valley opened out to the south as far as the eye could reach; the mountains on the left bending more to the north. At 3 P. M. crossed a small stream running to the south, whose bed, when covered with water, is dangerous to man and beast, owing to the sharp rocks in its bed, which, from the muddiness of its waters, are not seen. We halted at a short distance from its eastern bank. Our place of encampment was soon filled by the inhabitants of the neighbouring little towns, having raw goat's flesh, boiled beans, millet, and pudding for sale; as usual all Cumbrie, and every two or three women attended by an armed companion to see fair play; the men and women dressed in the same gay style as usual; upon the whole they were a fine, active, clean-looking people: most of the men had a bastard kind of greyhound following them, whose necks were ornamented with colours and strings of cowries. Every man working in the plantations, as I came along, was armed, owing, they say, to the frequent inroads of the Fellatas. At sunset all our visitors left us, and we had a severe storm of rain, thunder, and lightning.

Wednesday, 28th.-For the last five days we have been travelling through a rich and beautiful valley and over woody hills, and arrived at Womba. The capital of this province is called Kotonkora, and distant from Womba, north, thirty miles. Before the 
Fellatas took Haussa and its dependencies, Womba belonged to the province of Kashna; and at the death of Bello's father, it, along with the rest of the Towias, threw off the yoke of the Fellatas, declared its independence, which it still maintains, and joined the Towias, or confederation, against their conquerors. All the caravans from the east and west halt a day or two at this town, and pay for each loaded ass or bullock five hundred cowries; besides, the head man of each caravan makes a present, for which he receives, in return, a dish or two of cooked meat, or a sheep. The town is in latitude $10^{\circ} 35^{\prime}$, and longitude $7^{\circ} 22^{\prime}$. It is situated on a rising ground, having a commanding rocky hill of granite to the east, one on the south, and another to the north, all bare of vegetation except a few patches here and there; to the west is an open valley. A small stream of water runs past the western gate, from which the town is supplied with water. 'The valleys for two miles round are cleared, cultivated, and planted with millet, doura, yams, cotton, \&c., as is likewise every spare space within the walls this year, as there is a scarcity of grain this season throughout the whole of the eastern interior, owing to last year's rains being very scanty, and they fear this may be the same. The town is walled round; the wall is also in good repair, and has a dry ditch on the outside; its height between twenty and thirty feet. It has four gates, which are shut every night at sumset. The inhabitants may amount from ten to twelve thousand souls; they possess plenty of sheep, oxen, and horses, the latter apparently a cross from the large Bornou and the small native African, and are a strong, hardy race, like what in Scotland are called highland ponies, but not quite so tall.

Friday, June 30th.-At daylight loaded the bullocks, and at 7 A. M. sent them off. I went to the governor's house and took leave of him. He gave me a messenger to the chief of Guari, and lent me 
a man to lead my camel. After leaving him, I rode and joined the caravan. Passed two towns called Gilma, the one built on the top of a rocky hill, the other at a few hundred yards from its base. 'They are at hot war one with the other, and seldom a day passes without some one or other belonging to either town being killed. Yesterday we heard there were twelve of the lower town'speople killed in a pitched battle between them. Their usual field of battle was pointed out to me by the messenger; it is a clear spot of about three hundred yards broad, between the south wall of the lower town and the base of the hill. Parties of women belonging to both towns were working.in these fields, but parties of armed men kept walking up and down between them and the enemy.

Saturday, July 1st.--Leftour encampment, and travelled through a country well cleared and cultivated near the road planted with millet, \&c.; the soil, red clay and gravel. At 10 A. M. passed round the south side of a town called Akingie, which was walled, large, and populous, the environs cleared and planted with grain on the east side. Found the town's-people collecting the toll from the Fitakies of the caravan who had preceded us in the morning. They had here a regular toll-gate, not painted white and hung on hinges like those in England, but the collectors of the toll were lusty rude fellows, armed with clubs and staves, the head man with a sword. After passing the toll of Akingie the country became more hilly and woody; the soil stony and gravelly, and little cultivated. At noon arrived at the town of Curigie, where I halted, the head man of which, having provided me with a house, made a present of two fowls, with millet for my horses and camel. The walls of this town are extensive, but the houses are few, partly built on a hill and part in the valley. At this season both inside and outside of the town has a beautiful appear- 
ance, from the large spreading and shady trees inside the town. The louses, some of which are built on the top of the blocks of granite which form the hill, are beautifully situated; green plats, overhung by shady trees, growing out of the clefts of the rocks.

Sunday, 2d.-Morning dull and cloudy. At \%.30 A. M. left Curigie. The path through a woody country, with small cultivated spots here and there. The soil is red clay, mixed with sand and gravel, and diversified with gentle hill and dale. At one passed a town called Sabonque, apparently a favourite name in Kashna from the number of that name. They till the ground for a considerable distance, and plant it with doura, millet, yams, and sweet potatoes. Close to the east of the town runs a small stream, which is now full and deep. We had to unload the bullocks and carry the baggage over; a great many of them getting wet, and Pascoe lost my shot belt in the stream. In the evening we halted outside the walls of a town called Guber in Dushee. The head man, and the greater part of the inhabitants, were out of the town, at their plantations in the country, attending the growing grain; we therefore could get nothing for man or beast but grass. Guber in Dushee, or "the rock without an equal," is situated on a height, with sevcral large blocks of granite, inside the walls, which are extensive: few houses are to be seen, except those situated on the highest ground.

Monday, 3d.-At 7. 40 A. M. left Guber in Dushee wet and hungry. The country woody; the path stony, wet, slippery, and cut up by deep ravines, through which run streams of water; the descent and ascent dangerous to man and beast. As we approached Guari, the country became very hilly, and the path winding; the valleys began to be cultivated, and the road thronged with passengers; and on the sides of the road were the remains of camps 
of caravans; and as we drew closer to the city the camps were occupied by the merchants of the caravans bound to the west. At fourarrived at the walls of the old city, and entering the western gate, rode round and over part of the hill on which the city is built, by a footpath, which cuts off about two miles: entered the eastern gate of the new city, where I was met by forty horsemen sent by the chief to conduct me into the town. I rode up to the door of the chief's house or castle, who came out instantly, and received me very kindly, and, after exchanging compliments, he sent me with his chief eunuch to a house prepared for me, where shortly after was brought a live sheep, millet for the horses and camel, cooked meat for me and my servants, consisting of pudding made from the seeds of grass, the same as what is called tiff in Abyssinia, equal to any flour pudding made with milk and eggs in England: it is called asha in Iloussa: I had also two stewed capons, the largest I ever saw.

Tuesday, 4th.-I waited on the chief, and made him a present of a silk umbrella and other articles. I then told him that what I had given him did not belong to me, but to my master, the king of England, who had sent me to visit Houssa and Bornou, where I had been two years before; that I wanted the chief of Guari to give me his assistance and protection as far as he could give it. He said he thanked me for the present I had given him from the king, and I should have every protection and assistance he could afford; that he and the Fellatas, I knew, were at war, and that his sending an escort of horse to Zegzeg with me would be of no service, and only expose me to attack from the Fellatas who infested the road on the frontiers of the two states; but from the last town in his territory bowmen on foot should escort me as far as Fatika, the first town in Zegzeg, and under the dominion of the Fellatas, and then I should be in perfect freedom to go where I pleased; that his horsemen should go with me as far as the last town in his 
territory, and would provide every thing, and see me off, escorted by the bowmen, before they returned; that the bowmen were the best escort in the woods I had to cross between Guari and Zegzeg, and, God willing, I should perform it in safety, as I had done the long and dangerous journey I had already come; but that if I thought any other way was better, or if there was any thing I wanted, to mention it, and if it could be got in Guari I should have it. I thanked him; saicl, if there were any curious animals or birds, I should like to have them; and if he had any written account of the country, I should like that more than all. He said he had no written account of the country; that no one troubled their heads about affairs of that kind; that if I would remain with him in Guari some time, I should have all the curious birds and beasts in the country, but that at present every person that could be spared was out in the country attending the growing grain; that they had a scarcity over all the country last year, and they were afraid the same thing might happen this year, as the rains as yet had not been very abundant. After I left the chief I returned home, and opened all the cases, and put the things that were wet out to dry.

Guari, formerly a district of the province of Kashna, was conquered by the Fellatas a short while after their rising, along with the rest of Houssa. At the death of old Bello, this, with the greater part of the province of Kashna, made itself independent by joining in the 'Towia, or confederation and rebellion against the Fellatas. Bonaga, the chief of Zamfra, was the first to rise and shake the spear, as they express it. He was joined instantly by the inhabitants of the province of Goober, whose chief, a lad, was kept as a slave in Sackatoo; but, by the assistance of his countrymen, had made his escape, and now heads his people. The northern part of Kashna was the next to join, under a son of their former chief or governor. Guari and Katongkora, both districts of Kashna, 
and belonging to Houssa, also joined, but declared themselves independent of the authority of Kashna. The states of Youri and Cubbi have also since joined, as have Doura and the southern part of Zegzeg. Youri, they say, was forced to join by the others of the Towia, as their districts nearly surround it. The strength of Guari lies in the bravery of its inhabitants and the number of horse they can bring into the field - they say a thousand: this may be all true, but I think they owe their strength to the hilly and woody nature of their country. The capital of this district, also called Guari, is situated in latitude $10^{\circ} 54^{\prime}$ north, longitude $8^{\circ} 1^{\prime}$ east; built partly on the north-east side of a hill, and partly in a narrow valley, through which a muddy stream runs that is dry in the summer months; this stream rises only a day's journey in the mountains or hills south of Guari, runs through part of Zamfra, and divides in one part the states of Katongkora and Guari, and enters into the Kodonia in Nyffé. The city or town has two walls, the old and the new; the old in ruins ever since it was stormed by old Bello. At the rising of the Fellatas it surrounded the hill on which the city is built, and great part of another; the new wall runs over the ridge of the hill, cutting the town into one half the size it was formerly; and even now the wall is much too extensive for the inhabitants to defend, and appears enclosing a few scattered houses and villages, not a town or city. The house of the chief is like a walled village, with a large clay castle at one end: this serves as the harem of the chief, and is well filled, or, more properly speaking, there are a great number of women in it. The other houses in the enclosure are huts, or coozies, occupied by blacksmiths, weavers, tailors, dyers, \&c. all belonging to his household.

Friday, 7 th.-Morning cloudy. At 8 A. M. loaded the bullocks and camel, and sent them off. I went and took leave of the chief Abubuker, where I found an escort of four horsemen ready to con× 2 
duct me to the frontier. This was more than I expected; for both he and his people knew I was going to Bello: at least I told the chief I had a letter and present for him : at all events they knew I had to go through his territory-there could be no mistake as to that. The road from Guari was hilly and woody, and winding and rocky, and filled with sharp gravel stones; the soil a deep red clay; the rocks a slaty sandstone: a number of what in England are called the Malacca cones were growing by the sides of the streams.

At 1 P. M. passed the town of Makundi, where a large caravan from the eastward had just halted, a number of the merchants of which had seen me in Yourriba and Borgoo, and came to wish me joy and a blessing at being so near their country. A number of tongas, or camps, were around this town, some empty and some filled. Arrived at the walled town of Cazigie, where I remained for the night.

Saturday, 8th.- The country, as we approached Fatika, became more uneven and cut up by deep ravines between the long ridges which the land formed. At 5.30 P.M. passed to the south of Fatika, which is walled, and of considerable size. I sent to the head man to inform him of my arrival, and to tell him who I was, and that I was going to halt near the tonga, as the gates of the town were too narrow to admit loaded bullocks. At 6 A. M. halted near a large camp, or tonga. The caravan had preceded us from Guari, and had travelled all night through the wood. They said they had seen the robbers, but from the numbers composing the caravan they were afraid to attack. A short while after halting, the head man of the town sent me pudding, stewed meat, and millet for my horses and camel. I certainly felt very light-hearted and comfortable, as I thought now I had entered the territories actually under the dominion of the Fellatas. All my cares were over; not even thinking of my sick servant, or the chance of my having perhaps to-morrow as much anxiety as ever I had before. 
Sunday, 9th.-Morning dull and cloudy. At 8. 30 A. M. left our encampment to the eastward of Fatika, the road winding and very gravelly; passed through several plantations of millet, sweet potatoes, indigo, and dourra, the path winding to the south and south-east, when we came to the ruins of a large town, where we turned up, E.S.E. at noon. At 1 P. M. saw the mount inside the walls of the old city of Zaria, appearing over the long ranges which the land forms, like islands in the midst of the sea.

Monday, 10th.-Morning cloudy, with rain. At 7 A. M. the rain ceased, and we loaded our animals, and started at eight. Shaped our path across gentle rising and declining ridges; the soil a deep red clay, with now and then rocks of sandstone and clay ironstone, and the country woody. Within about four or five miles of Zaria the country became altogether clear of wood: except a patch here and there, all was in pasture, or planted with rice, millet, and dourra. Herds of beautiful cattle were feeding in the valleys, or lying chewing the cud on the higher grounds. Zaria was seen to the eastward, and known by its tall trees, like a long avenue of gigantic poplars; running across the horizon from north to south, stretching from the south end of one detached mount to the north end of another. At two, entered one of the gates on the west side of Zaria; but, instead of finding houses, I could just see their tops over the growing grain. At about a quarter of a mile distance all was walled fields, full of growing millet and dourra, with here and there a horse or mare tethered in the open spaces.

At sunset Abdulkrum, the acting governor, arrived, and waited on me instantly. He was very kind, offered me his own house to live in if I did not like the one I was in; sent for a fine fat sheep, with plenty of provisions for man and beast.

'Tuesday, 11th._Morning dull and cloudy. After breakfast I had a visit from Abdulkrum. I told him who I was, and what I was, and where I was going; and desired he would give me a 
messenger to Kano, as I intended going to Sackatoo by that route. He said he would send to the sultan, or governor, and inform him of my arrival; that the messenger would return in three days, and in the meantime I should have every assistance that he could afford me. I told him I wanted the loan of a horse to Kano, and should leave my little mare until she recovered, when she was to be sent to me, and I would pay all expenses. Abdulkrum appears to be a very good fellow, but is in great distress he tells me; and there is nothing in his possession but he will give me if I will only relieve him, for he declares I can. A number of visitors coming in put an end to his story, as it appears to be with him a great secret.

'The old city of Zaria was taken by the Fellatas about a month after they had taken the provinces of Groober and Zamfra, in or about the year 1800, as they do not care much about a year or two. It only stood a siege of two days; the sultan and the greater part of the inhabitants flying to the southern and western part of the province, which is hilly, and inhabited by pagans. Here they still remain, and preserve their independence, though the Fellatas seldom let a month pass without making an attack on them; but of late they have suffered severely, and begin to be more cautious in their attacks. The old city is now only known by its ruined wall surrounding the before-mentioned mounts, which were in the centre of the city.

The new city built by the Fellatas, the walls of which extend from the south-east side of the old, about two miles to the south, enclosing a great space of ground, on which are built a number of little villages and detached houses, is surrounded by high clay walls. Abdulkrum's house, where I lived, is in latitude $10^{\circ} 59^{\prime}$ north, and longitude $8^{\circ} 42^{\prime}$ east. Near the centre of the wall stands the principal mosque, built of clay, having a minaret about forty or fifty feet high. The principal market is at the south end, inside the walls, and here the caravans make their tongas, or camps. One 
twentieth is exacted from the merchants as a duty; and they dread halting at Zaria, from the rapacity of the inhabitants, who are all Fellatas, and often keep travelling by secret paths through the woody country, to evade the city, until they enter the province of Guari. The house of the governor is north of the great mosque, and is surrounded by a high clay wall; inside this wall are large coozies, or huts, surmounted by ostrich eggs, and some single rooms of a square form, with a flat roof. The louses of the principal inhabitants are much the same. Of the number of inhabitants I can form no estimate: they say there are more than in Kano, which I should suppose to contain 40 or 50,000 at least. 'They are mostly all Fellatas; a great many of them from Foota Bonda and Foota Torra, and know the French and English well they say; but I am sorry to add, that they have not improved by their acquaintance. 'They rattle over the names of the towns between Sierra Leone, or the Senegal, and Timbuctoo, like a, b, c, then sit down, and will not start until they get something. These fellows are generally armed with French fusees. They prefer the guns of the French and the powder of the English. The late governor was a native of Foota Bonda: so that the Foulahs and the Fellatas are the same people. Foota Bonda, Foota Torra, \&c. they call Meli. They now possess Jinnee, near Timbuctoo, and I think will soon have the whole of the interior. Inside the walls there are a great number of shady trees, which are pruned every year for firewood; they look at a distance like immense poplars: swamps, corn fields, and green plats, make up the rest of the town. Date trees, palm oil trees, papas, melons, plantains, Indian corn, millet, dourra, rice, yams, sweet potatoes, \&c. are in abundance, particularly rice. They say they raise more and better rice than all the rest of Houssa put together. Horses, sheep, and horned cattle abound in every part of the province inhabited by the Fellatas. Game is also in abundance; such as antelopes of all the different kinds. Guinea 
fowls and partridges are also in great numbers. 'The elephant and buffalo inhabit the southern part of the province, which they say is twelve days soutl of Zaria, and reaches close to the salt water. It is bounded by the province of Kano to the east; Jacoba to the south-east; by the mountains inhabited by pagans to the south, where they say the sea is; by Nyffé to the south-west; Guari and Kashna to the north and west. The environs of the city are beautiful, being formed of gentle ridges of land and plains; here and there fine large shady trees, and small streams of water; the rocky mounts to the north and south adding to the beauty of the scene. A small river, dry in summer, runs at a little distance from the eastward wall: its course is south.

Friday, 14th.-Morning clear. No messenger having arrived from the governor, as was expected, I had the bullocks and camel loaded, and told Abdulkrum I would stay no longer, and if he attempted to stop me, it would be at his peril. He said there was not the least objection to my going ; that, on the contrary, he would send a messenger of his own with me to Kano, and should accompany me part of the way. It was $8 \mathrm{~A}$. M. before I was able to leave the town, Abdulkrum proceeding with me: he has behaved very well to me while I remained in Zaria, and is as decent a Fellata as I ever met with ; and he is the only man in the place who bears a good name with strangers. Poor man, his secret came out at last. He was very earnest and rather bashful about it for a Mahometan. It was as usual with them who have too many wives: one, he said, was the governor's daughter, and he was convinced I had medicine that would be of use to him. It was too serious a matter, and lay too near his heart, for me to laugh at him, or to say I had none; so I gave him a box of Seidlitz powders, the effervescing of which surprised him very much, desiring him to take one once a week. He was made perfectly happy, and fully believed in their virtue. It is the first time I have given medicine for such a disorder, generally 
laughing them out of asking me for such a thing. As he and I rode after the bullock, a great deal of our conversation was about England, which he, as well as a great many others here, declares to be a small island in the midst of the sea. I had hard work to convince him to the contrary. He then talked a great deal about the inferiority of the Christians to the true believers in battle. I told him he had never yet had Christians to deal with in battle, or he would tell another story. "Oh! do not say that," says he; "did we not kill forty at Adamowa, and make all the rest run away?" I said they were all Mahometans and Arabs, not a Christian amongst them : but all I could say he would not be convinced, until I told him he lied like a thief, and whenever I saw Bello I should insist on his writing to the governors of the difierent provinces of Houssa, to inform their people of the truth of that affair: that it was Arabs and Mahometans, headed by Boobecker Bookaloom, who made the attack on Adamowa; and that they had, to save themselves, taken advantage of our being in Bornou at the time to throw it on our backs. Mr. Abdulkrum began to be a little alarmed at the earnestness of my language and threat, and begged I would think no more about it; he himself knew it was a lie told by the Arabs to save their credit. We parted not quite such good friends as we had been.

The country at present, on this side of Zaria, looks like some of the finest in England, about the latter end of the month of April. All around is green and beautiful, with only trees here and there. The soil a red clay, mixed with gravel. The cultivated ground continued until $11 \mathrm{~A}$.M. when we entered a wood of low trees, which continued until noon, when we found ourselves amongst the cultivated grounds belonging to the town of Leokoro, which we passed, and halted on the east side. It is of considerable size, walled round, but the wall is in very bad condition, being broken and falling down in several places. The houses are in good repair, 
and the inhabitants numerous. Towards sunset several large herds of cattle came in from grazing in the neighbouring woods, and were secured in thorny enclosures outside the walls for the night.

Saturday, 15th.-At 4.30 P.M. arrived and halted at a town called Roma, in English, Soup, whose walls are extensive; and, from the number of shady trees within them, must have once been a populous and well inhabited place. The present inhabitants do not amount to more than forty, poor, mean, and miserable. They were all collected under one of the old shady trees in the town to receive me, with their chief man at their head, bearing a long white wand, or peeled pahm-tree branch in his hand, dressed in a ragged dirty white tobe, his skin spotted black and white like a leopard with disease. He conducted me to his house, which was large and spacious; but the courts were overgrown with weeds and grass; the roofs of the huts falling in; the floors wet, damp, and dirty. I could not amongst the whole find one fit to shelter man or beast. I went out, and he accompanied me until, amongst the untenanted houses, I found one, where I put my baggage for the night. He brought me a little corn in a gourd for my horses, and I asked him the cause of the sad state in which the town was: he said, the Fellatas, and held his peace. "Why is your house in such a state?" I asked. He said he once had fifty wives, but they had all run away one after another, and he could not take care of it himself. Plenty of guinea fowls came to roost on the shady tree. Towards sunset I went out and shot six, which served all hands.

Sunday, 16th.-At 12. 20 halted at the town of Aushin, where I was provided with as good a house as the place afforded; and this being the day of the aid kebur, or great feast, they had killed a bullock, of which the head man of the town sent me a part, with Indian corn for my horses and camel. I had not taken possession of my house more than ten minutes, and hung my watch and compass up to the rafters, as was my usual custom, than, having occasion 
to go out, I found my watch torn forcibly from the ring; but I fortunately caught the thief, who was one of the bullock drivers: I threatened him very much, but was glad I had got my watch again without any serious injury. The bullocks on this day's journey were nearly all worn out; it was with great difficulty we could get two of them on with very light loads.

Monday, 17th.-Having passed Roma and several other towns, at noon of this day we entered the town of Dunchow, the first to the westward in the province of Kano. I rode up to the head man's house, who was just coming out of his door to take his ride; a jolly looking tall Fellata, about thirty years of age. After we had exchanged compliments, he took me to a very good house to lodge in, and promised to send me every thing I wanted, which was food for man and beast. I got corn sent me in abundance, but nothing else; all his other promises proved to be nothing but empty words.

Tuesday, 18th.-Clear and cool. Thermometer at sumrise $68^{\circ} \mathrm{F}$. in the open air. After giving the head man of Dunchow a knife, and a lecture for not performing his promises to me, in giving me meat or milk, or lending me a horse, he said, they had no meat, because they had killed no bullock; no milk, as all the young women were dancing last night, as their custom is after the aid, and they did not milk the cows; his horses had all been killed this summer at the war with the sheik of Bornou. All these excuses were made with as much ease as he made the promises, and I could not help admiring the courtier-like manner in which he behaved, though he has only been here a month as governor. At 7 A. M. 1 left Dunchow and its polite governor, and travelled through a well cultivated and populous country, the inhabitants of the villages all out in their plantations, giving the millet and dourra the second hoeing, and drawing the earth up to the roots of the grain : the soil a fine black mould, covered with a thin layer of sand. Passed 
several plantations of rice, which was sown in beds in the low and swampy grounds; also beds of sweet potatoes, yams, and a root called goza, like a small short yam, more watery, and of a yellow colour inside: it has a broad flat leaf.

At 2 P. M. entered the town of Baebaegie. I rode to the house of the governor, whose head man gave me a part of his house to lodge in ; and shortly after I had halted he sent me a sheep, two fowls, some wheat, the first I had seen since I left England, and plenty of millet for my horses and camel. I sent him in return a knife, six yards of red silk, a gilt chain, and a pair of scissars. In the evening the governor sent me pudding, boiled rice, milk, and stewed meat.

Wednesday, 19th. - The town of Baebaegie is in latitude $11^{\circ} 34^{\prime}$ north, and longitude $9^{\circ} 13^{\prime}$ east, and stands as it were in the midst of a large plain, having in sight, from the granite mount about a musket shot outside the southern gate, the hills of Nora, about ten miles east; to the south, the mountains of Surem, distant about twenty-five miles; to the west I could distinguish the tops of one or two of the hills of Aushin, in Zegzeg; to the north a plain bounded only by the horizon; to the north-east the two mounts inside the walls of Kano could just be distinguished above the horizontal line, bearing north-east by north. One hill bore north, breaking the horizontal line, twenty or twenty-two miles; the land, every where the eye turned, looked beautiful; the grain was just high enough to wave with the wind; little towns and villages were numerous; the trees full of foliage, none being left hardly but such as were fit for use, such as the micadania or butter-tree, the nutta or durow, and the tamarind: heads of fine white cattle were seen grazing on the fallow ground; horses and mares were tethered in the small spaces left between the plantations in cultivation; women, to the amount of a hundred, were thrashing out corn with large sticks, on the flat rock at the base of the mount, the wind, blowing fresh from 
the westward, serving them as a winnowing machine. The town was below, in the form of an oblong square, the four sides facing the four cardinal points; the head man's house in the centre of the town, and is like one of the old keeps or castles in Scotland, near the Borders; it is also of the Moorish form, and the general one for all the governor's houses in Houssa. A high clay tower, through which is the gate or entrance from each side, overtops a wall of clay about twenty feet high, in the form of a square; inside are huts or coozies for the women, eunuchs, domestics, and horses; the governor occupying the upper part of the tower in times of alarm and danger, and his men-slaves and armed retainers the lower. This, like all the others, is built of clay, and is three stories high, with a flat roof and battlement. In the lower story, at each side, and above the gate, are oblong holes, which serve for archers and to give light in the upper stories; the windows are like ours in England in form, four on each side, but no attention as to regularity in placing them; the windows are either shut by a mat on the side next the wind, or by a number of coloured and plaited lines of grass strung over a small rod, which is hung across the top of the window; the ends falling down, admit sufficient air and light, and keep out flies. 'This plan is also used for the doors of' inner apartments in the lower houses, and requires no opening or shutting. The rooms in the town are supported by pillars formed by lashing long poles together until sufficiently strong, and, when they are up, plastering them thickly over in all parts with clay, and then a coating of cow-dung, to prevent the white ants and other insects eating away the wood; the great beams are formed in the same manner. The floors of the upper rooms are first laid with rafters of stout poles, then short diagonal pieces are laid over as close as they can be laid, then a coating of clay and small gravel is laid six or eight inches thick. The walls are made, first by mixing clay well up with a little chopped grass or cow-dung, and making 
it up in lumps of two handfuls, and letting it dry in the sun; when dry, they build with them as our masons would do with rough stones, laying a thick layer of well-wrought soft clay between each layer of hardened lumps, and a good thick coat outside: their hand is the only trowel; and, without plumb-line or level, they manage to make pretty fair walls and buildings, taking these things into consideration. 'The walls outside, before the commencement of every rainy season, get a fresh plastering, the tops are repaired, and parts that may be washed down are built up. The water is conveyed from the tops of the houses, clear of the walls, by long, baked, clay funnels, like what are used on the tops of smoky chimneys in England, and look like great guns mounted on the tops of the walls. The other houses of the town are like almost all others outside the capital towns, a number of circular huts within a high, square, clay wall; frequently a single room, with a flat roof, used by the master of the house as a safe repository for his goods. Every house has two or three date trees within this wall or enclosure, which bear fruit twice a year, like those of Kashna and Kano; once before or at the commencement of the rains, the other after the rains a month or forty days. They use two pieces of flat board or gourd, one fixed, the other moveable, to which is attached a line for the purpose of clapping one against the other to frighten the rampire-bat and a kind of jay which lodge on the trees and destroy a great quantity of fruit. The ibis, stork, crane, adjutantcrane, and several other birds, build their nests in the shady trees of the town. A market is held daily, which is well attended: grain, oxen, sheep, and all the necessaries of life, abound. A tame ostrich is kept in the market-place to avert the evil eye-a Bornou and eastern custom. There are several places of prayer in the town, but one principal mosque or jama, as they call them, stands on the right of the governor's house, forming one side of the square before his door. 'The inhabitants may amount to about 
twenty or twenty-five thousand, the greater part of whom are refugees from Bornou and Wadey, and their descendants, who are all engaged in trade : from the little $I$ saw of them, they appeared to be cleanly, civil, and industrious. In the afternoon I went through a great number of these houses, shooting pigeons, of which there are four kinds here: the domestic or house pigeon, the large wood dove, a larger kind with a fleshy substance round the outside of the eye like the carrier pigeon, and the small dove with purple breast and black ring round the neck. The inhabitants offered not the least objections to my shooting in their court-yards, but were as much amused as I was, and afforded me every assistance in procuring the wounded birds. At sunset I took leave of the governor, who lent me a horse and a messenger to go with me early to Kano to provide a house, for I had not yet heard from Hadje Salah. The governor's son sent me a present of a turkey and some wheat, but I sent him nothing in return, as all my things were packed up ready for starting.

Thursday, 20th.-Daylight, fresh breezes and cloudy; thermometer, at sunrise, $75^{\circ}$ Fahrenheit. Landed the bullocks, and saw them out of the north gate of Baebaegie, when I started ahead, on the horse I had borrowed from the governor, his servant and the messenger of Zaria accompanying me. I left the baggage in charge of Richard, desiring him to halt at the nearest town or village if it should come on to rain, and not to start in the morning if the weather was bad. My road was through a wellcultivated country, the soil clay and gravel; the villages were numerous, the inhabitants of which were busy in their plantations, dressing up the earth to the roots of the dourra, and hoeing away the weeds. The road was broad and good, thronged witl passengers, asses and bullocks loaded with goods and grain, going to and returning from Kano. At 7 A. M. crossed a small stream which runs south and falls into the Girkwa. At 8.30 A. M. passed the 
town of Madagie, which is walled, and appeared to be well filled with houses and inhabitants. At noon, arrived at the banks of the river which passes Girkwa, and which rises amongst the hills of Aushin. All the streams to the south of the granite ridge passing Roma, close to the south of Kashna, fall into this river. One considerable river passing Duncomee and Fariroa, flows south of Kano close to the walls of Girkwa, runs east past the town and hills of Dushie, near Katagum, and enters the river Yoau near Hadega. This is the river which has been spoken of by the Arabs as coming from Timbuctoo, and continuing its course to the Nile of Egypt. It is dry for nearly the whole length of its course during six months: the stream, when full, is broad but shallow; at this place, about 100 or 120 yards across: its waters are now muddy with yesterday's rains; the depth five feet. I got wet up to the middle as I crossed, the horse I rode being a small one, and at times off his legs and swimming. I halted on the other side to dry my clothes, and after an hour's rest under a tree, when my clothes were pretty well drained and half dry, I again started, and, about five in the evening, arrived at the city of Kano. 


\begin{abstract}
CHAP'TER V.
JOURNEY FROM KANO TO THE CAMP OF BELLO, AND FROM THENCE TO SOCCATOO.
\end{abstract}

ON entering Kano, I immediately bent my way to the house of my former agent, Hadje Hat Salah Byoot; but I soon saw that both he and the Arabs that were present would rather I had come from the eastward: they were all in fact in low spirits about the war with Bornou, which had shut them out, for some time past, from all communication with Fezzan or Tripoli. The caravan for these countries had left Kano twenty days ago for Kashna, to try whether they could not succeed to get home by way of the Tuaric desert. This has deprived me of the opportunity of sending home my journals and letters; but it would have been a great risk, as they have to go through the capital of the son of the former sultan of Kashna, who is in rebellion against the Fellatas; and the 'Tuarics have not allowed a caravan to pass, except those of the merchants of Ghadamis, for these many years past; and on these they levy a contribution.

Hadje Hat Salah Byoot, my former and present agent, is the richest man in Kano, an Arab of the tribe of Majabra, inhabiting the country to the east of Augela, adjoining it. They, like the Augela people, are great merchants. He was formerly the agent and merchant of the hereditary governors of Fezzan; he was the cause of their being removed and dispersed by the bashaw of 
'Tripoli, who would still have continued the family in the government, if they had not prevented his people of 'Tripoli, and the other towns on the sea-coast, from trading to the interior. They even prevented, all in their power, the bashaw's sending Mohamed El Mukni with presents and a letter to the king of Waday; they went so far as to endeavour to stimulate the chiefs of the Tibbo tribes to cut them off, offering them a reward and protection if they would do so. Mukni and his people were accordingly attacked on their return, but by their bravery beat the 'Tibbos in every attack. When they found they could not destroy them in this manner, they bribed the guides, who led them astray in the desert, where all their slaves, and most of their camels, perished; and Mukni arrived at Tripoli with the remains of the merchants, who were mostly all ruined. A few years after this, the bashaw sent another mission under Mukni, with presents to the sultan of Bornou, and was again accompanied by a number of merchants from the sea-coast. The governor or sultan of Fezzan did not try by open force this time to oppose Mukni's passing Mourzuk, but sent again to the Tibbo chiefs and Hadje Salah, to Bornou, to prejudice the sultan against Mukni ; but all without effect. Some of the Tibbo chiefs were now friends with Mukni, and gave him the letters the governor of Fezzan had sent him. The sultan of Bornou was much pleased with the bashaw's present, and gave every encouragement to the people of Tripoli to come and trade to the interior, and sent a large present of slaves, ivory, \&c. to Mukni for the bashaw, who had carried him two small field-pieces, those now in possession of the sheikh; but the Fellatas invaded and took the capital, and all the presents were lost. Notwithstanding this, on Mukni's return to 'Tripoli empty-handed, he was followed by Hadje Salah, who did all he could to prevent the people of Waday from serving him, by selling him the provisions necessary for him and his people in crossing the desert. He first got the people of Kanem to attack 
the Tripoli caravan; the people of the caravan of Fezzan not rendering them any assistance, and always encamping out of gunshot distance from them. Next they were attacked in the Tibbo country, where the people of the Fezzan caravan assisted the Tibbos against them; but Mukni again overcame them, and arrived at Mourzouk. Here the gates were shut against him, and every person was forbid to provide him or his people with provisions, or hold any communication with him, on pain of death. Notwithstanding all these orders, they were supplied by their friends inside the town, principally the cadi, who used to send them out provisions on asses, as if laden with manure. After this, it was eighteen months before the bashaw would grant Mukni a force to depose the governor of Fezzan.

Sunday, 20th.-This morning the whole city was thrown into considerable alarm by a merchant from Ghadamis being found strangled in his bed. His female slaves were suspected of being guilty of the murder, as two or three similar cases had happened before. The governor of Kano sent to Hadje Salah, as chief of the Arabs, to know what he would have done on the occasion; whether the slaves should be sold out of the country, or whether they should be put to death. It had been customary, in cases of this kind, to send the perpetrators of similar crimes to the sea-coast, to be sold to the slave-dealers. Hadje Salah and the principal Arabs came to my house before they went to the governor, to ask my advice on the occasion, and to know what we should do if such a thing were to happen in England. I told them, that all the slaves would be confined separately, and strictly examined, and that if the fact was proved, all those concerned would be hanged-not one would escape. 'I'hey said that was the proper way, and that no man would be safe in Kano if they were to escape. I took this opportunity of asking them how many slaves there were in Kano in proportion to free men; they said, about thirty slaves to every free man. I told 
them they had better keep a good look out, as, were the men once to know their own strength, they would soon take the place from their masters. I informed them in what manner the slaves in St. Domingo had made themselves free; and pointed out to them the case of the slaves in Yourriba, who had killed their masters, and now formed a free people there.

Monday, 21st.-I visited the governor, who was very civil and talkative. He said that the gadado was coming to Kano, but if I wished to go before he came, I should have a camel to carry Bello's present, and two men, as also a messenger ; but he added, that it was very uncomfortable travelling at present, for every day and night the men and camels were out in the last expedition at Donna, that they had been exposed to very heavy rains, and that most of the people and animals were knocked up. I said I was all ready to go, and, if he had no objection, I would start the day after tomorrow. He said, well; and sent for a messenger, to whom he gave strict charge to see me well used and lodged, and safe into the hands of the gadado. I found two of my barometer tubes broken in the box, by the sudden transition from heat to cold in a tornado.

Tuesday, 22d.-Found I had made a mistake in the month of May, having given it only thirty days instead of thirty-one.

Wednesday, 23d.-Rain and lightning all day, so that I conld not start in the afternoon. I waited on the governor and took leave.

Thursday, 24th.-At 9 A. M., it having rained all the morning, I had the camels loaded, and took leave of my servants, whom I left, with much regret, in a land where they were perfect strangers. Richard was still unwell with dysentery. I left with him instructions how to proceed home in the event of my death, and also strict orders to Hadje Salah to afford him and Pascoe every assistance, even the same he would have given to me, and that he would 
be well paid by the consul at 'Tripoli. I also desired him to allow Richard one thousand cowries, to keep the house and horse; my poor little Boussa mare having died a few days before. I had been obliged to draw a bill for five hundred Spanish dollars in favour of Hamada ben Medoon, for which I had to take a horse at more than double its price, and only got 1500 cowries for each dollar-just one half,-such is the rate of the country. This money I left in the hands of Hadje Salah for the use of my servants, which amounted to 250,000 cowries (not 100 dollars), the price of the horse being 500,000 cowries. I left them with much 1egret, as I was in very bad health myself. I was accompanied as far as the horse gate (Coffin Dalkie) by Hadje Salah, Shereef Ali, a Tunis merchant, Hamada ben Medoon, and all the principal Arabs, as they thought that I should bring about a peace between the sheik of Bornou and Bello.

After leaving the walls of Kano the country was well cultivated on every side, and planted with Indian corn, millet, doura, potatocs, indigo, and cotton; but the road was very disagreeable, all the hollows being full of water. At 11.40 came to a stream of ruming water, at this season at least a quarter of a mile broad. At 19.80 got all the people, and baggage, and the camels, across. I was wet up to my seat in the saddle, and once or twice the horse was swimming. Started again, and at four halted at the walled town of Toffa, the walls of which, since the death of Duntungwa, the rebellious governor of Dumburta, have been allowed to go to decay; and unless they are soon repaired and built up, the town will, in a year or two, be without walls. I was provided with a house, and had even milk and pudding--not like our puddings in Britain, but Indian corn-flour boiled in an earthen pot, and stirred with a large stick, without salt or fat, and, when thick enough, it is made up into pieces of about two pounds each, and eaten with milk, if it can be got; if not, with a sauce made of the dried leaves 
of a certain plant and a little butter. It is the general food for the second meal in all parts between the Quorra and Bornou, and sometimes also in the latter place, if they have millet.

They are now gathering in the indigo, which they cut about two or three inches above the ground, bringing what they cut off home, and strip off the leaves, which are laid in a circular heap, and left to rot or ferment until the end of the rains, when it is beaten in the troughs or wooden mortars, and allowed to remain until dry. In other places they beat it in the troughs as soon as cut, and let it remain until dry, when what they do not want for use is carried to Kano and sold.

The houses in Toffa are few, and all the spare places in the town are planted with millet and doura. The inhabitants do not amount to more than two thousand. During the night we had thunder, lightning, and rain.

Friday, 25th.-Morning clear and fair; gave the head man ten gora nuts, ard my landlord ten, and started at r. $10 \mathrm{~A}$. M. 'The country cultivated only in parts; saw several large herds of very fine cattle belonging to the Fellatas. They follow the cry of the herdsman, which is ah hea hay! in a soft but shrill cry, and the cattle, lowing, follow the sound. At ten passed a walled town called Siawa; and at noon another walled town called Gagai. At this last town the land was all in cultivation. Formerly, when Duntungwa was living, they durst not stir out of their towns; now he is dead, and his son submitted to Bello, every one tries who can plant the most. At 2 P.M. arrived and halted at a walled town called Grongodi, where I was provided with a house. 'I'he walls of this town are also falling to pieces. All the spare places were planted with millet and doura. A plentiful market was holden outside of the town. In the shady tree close to the house in which I lived were birds, a little larger than our sparrows, with a jet-black head, and a bright yellow in the neck, breast, belly, and under the 
wings, and the back a dusky green; chirped just like the sparrow: hundreds were building their nests in this and the other trees, which they do at the extreme branches or twigs, and are sown together with leaves; the nests are platted with grass, and have their entrance at the bottom. Both male and female work at the nest, and they lay about six or seven eggs. During this season they are very busy, and keep up a constant chirruping and flutter under their nests and about the trees.

Saturday, 26th.-Last evening I had a long and severe fit of the ague, which continued on me until daylight. In the morning it came on to rain, thunder, and lighten, which continued until near noon, when it cleared up. I had the camels loaded, giving the head man of the town twenty-seven gora nuts, as he had sent me a young sheep, plenty of milk, and corn for my horse. Left Gongodi; the path winding through plantations of millet, doura, cotton, and indigo here and there dispersed in the woods. Crossed a small river, and several streams whose courses were to the eastward. The soil a red clay mixed with sand, and only scraps of rock, of clay ironstone, and large blocks of granite. The water from the leaves of the trees made us all wet, and one time I had nearly lost my eye by the branch of a tree while looking at my compass; as it was, I got my face badly torn. At 2. 30 P. M. it came on to rain, and being close to the town of Koki, I halted for the night. The walls of this town are also falling to decay; but $\mathbb{I}$ observe with pleasure that as the walls have fallen the houses appear to have increased. I was provided with as good a house as the place afforded, and was plentifully supplied with provisions.

Sunday, 27th.-Clear morning, with light flying clouds. At 6. 30 A. M. left Koki. I gave the head man thirty gora nuts, as he had given me a plentiful supply of milk, and millet for my horse and camel. 'The road was excessively wet, being nearly every step midleg deep, and very slippery. The decayed ant-hills not being seen, 
the camels several times sunk up to their bellies, when they had to be unloaded. I constantly rode behind them, both for the safety of myself and horse, as also to render that assistance and encouragement to my servants which was necessary, who certainly suffered much, having to wade by the side of the camels the whole way. Thank God! not one fell sick, or uttered the least complaint. I sent the Kano messenger on a-head, as I heard the gadado was on his way to Kano, and only a day or two distant from me, to request he would detain the governor of Adamowa until my arrival, as that person had only left Kano a few days before me with his retinue; and, in the event of my joining him, I should not have any occasion to wait at the town of Torri for an escort to conduct me through the woods of Goudami. At 11.30 passed the town of Duncamie; after which the roads were the worst I have ever seen, or rather, in fact, there were no roads at all. Every where the surface was a swamp, the men sometimes up to their middles in water for half an hour at a time; the path leading through fields of millet and doura. Thus the road continued until 5. 30, when it came on to rain, thunder, and lighten. My servants stripped to the buff, and put their shirts under the hides that covered the baggage, to preserve them dry until they halted. I got wet to the skin, yet had a burning thirst - at times hardly able to sit on horseback, until relieved by vomiting. I would gladly have lain down any where, but there was not a spot clear of water. In this condition myself, my men, and animals continued until 6.30 P. M. when I arrixed, and halted at the town of Jaza, in the province of Kashna, where I lay down by a fire in the house of the head man of the town, after being assisted off my horse. At no time am I possessed of a sweet and passive temper, and when the ague is coming on me it is a little worse. The head man made a great many difficulties; 1 gave it to him in all the Houssa language I possessed ; but it was all lost on him. These Kashna bears are rude, and though they pride 
themselves on being the most polite and the best in Houssa, calling all the rest infidels. He, to make up the peace, left me in possession of the house, and ordered his servants to get food for my people, horse, and camels. I suffered severely during the night with ague and cramp.

Monday, 28th.-Morning clear. As I did not intend starting early, on account of last night's illness and the people getting the wet things dry, at ten the governor of Kano's messenger arrived, whom I had sent to the Gadado, with a request from him that I would stop for the day and he would meet me, as he intended halting at Jaza. At 11 A. M. the Gadado arrived, with a numerous train of attendants on horseback and on foot. The horsemen armed with spears, swords, and shields; the foot with swords, bows, and arrows. The women were behind; some riding on horseback a-straddle, some on camels, others, less fortunate, were walking, and carrying the gourds and kitchen utensils. As he passed my house I went out to see lim: he had four long trumpets and a pipe, like the pipe of a bagpipe, and two drums before him. When he came up he dismounted, and taking me by the hand, we walked, liand in hand, to the house prepared for him. He inquired kindly after my health, and how I had found my friends in England; said Bello had received my letter from Koolfu, in Nyffé, and had sent a messenger there to bring me up: he said he had never received my letter from Bornou appointing where his messengers were to meet me on the coast, neither had he received the one sent from Katagum. The Gadado advised me to return to Kano with him, as the roads were so very bad ahead; that to such a small party as mine it would be impossible to get through; that he would have sent to the governor of Adamowa, but he was already five days' journey aliead of me, and no messenger could overtake him before he got to Soccatoo; that it would be better both for my health and comfort to go and return with him after the rains, and that I slould want for nothing. 
I said I would take his advice, as, from my own ill health and the badness of the roads, I saw we should soon be all knocked up, both man and beast. I had a plentiful supply of every thing.

Wednesday, Oct.11 th._L Last night my horse died, and this morning I lost my pocket journal and remark book*, spectacles, inkhorn, and pens, \&c., which my servant had laid on the saddle outside the door of my hut, ready for me when I came out. The person in whose house I had lodged while at Baebaegie I had permitted to remain in the same enclosure; and my servant at once accused him and his men of the theft. I was desirous of searching them, but they made off the moment that the theft was discovered.

At 7 A. M. I proceeded on my journey, passed through a large village, and several times crossed the river which I have frequently before mentioned as coming from the granite hills, to the south of Kashna;-it here winds beautifully, with steep and high-wooded banks, sometimes composed of rock, and sometimes a mixture of clay and rock. My camels I could hardly get along, as they were nearly worn out with sores and fatigue. The country around Zurmie is well cultivated, and planted with millet, Indian corn, and dourra. The villages are numerous, the soil a light red clay, mixed with small crumbling rocks scattered over the surface, which is generally covered with a thin layer of sand.

The army has now increased to a large size, the forces of Zurmie and Jaroba having joined, the roads on every side crowded with horse and foot, camels, bullocks, and asses, all striving who shall get foremost. Some of the people of Zurmie are entirely naked, save only tanned sheep skin bound round the loins, cut into tassels, and ornamented with cowries, their woolly hair cut in parts or shaved, the rest plaited and formed into crests, circles, \&c. Some have it drawn out, and hanging in shaggy ringlets, which gives them a wild and savage appearance.

* It does not appear that he ever recovered them-hence the hialus in the journal. 
About noon, arrived and halted at Quarrie, and immediately waited on the Gadado, to inform him of the robbery, and by whom I had every reason to suspect it was committed. He promised to send off to the governor of Kano, and to desire him to have the people of Baebaegie searched; and there was little doubt but that I would have my books restored.

By the assistance of one of the Gadado's principal officers and a near relation, I hired a bullock to carry my baggage to Soccatoo for 5000 cowries; as, after the load had been removed from the back of the camel that was worn out, the poor creature was unable to rise, and was in consequence killed, and the carcass distributed among the poor.

Thursday, 12th.-Morning clear. Having waited in vain for the stolen property until mid-day, I then started, and found that the bullock which had been hired for me was miserably thin, and had the itch very bad; and that if offered for sale, it would not have brought me more than 3 or 4000 cowries.

After leaving Quarrie, the road lay through plantations of millet and dourra. Passed through several villages and one walled town, also called Quarrie; crossed the river Foutchir, at a ford about four feet deep. The river was upwards of one hundred yards broad, and full of water, with a current of about two and a half or three miles an hour; the banks low, sandy, and woody; and here it is close to its junction with the river Quarrie, which is on our right, running to the north. We travelled along its banks for an hour; and after leaving it, the country became a succession of sandy ridges and swamps, and thick woods, the principal trees of which were the acacia and a mimosa. Both my bullocks and camel were fairly exhausted; and I had to wait until these animals had got some rest, and until the heat of the day was over: the poor camel was unable to move.

At sunset, no assistance arriving from the Gadado, and no mesA 42 
senger with my lost books, I hired five of the footmen belonging to Zamfra, to carry the camel's load for 2000 cowries, as far as the camp; and the exhausted camel I left to its fate. We had not proceeded far, however, before a messenger arrived from the Gadado with a camel, when the loads were taken from the bearers by force, by the Gadado's messenger ; but I gave them 500 cowries for their assistance, and they were well pleased, and returned me many thanks. My servants had carried the greater part of the bullock's load on their heads all day; and I could not but admire their patience, as their only food in the morning was a little ground dourra and water; and of this I was also obliged to partake.

It was $9 \mathrm{P}$. M. before we arrived at the camp, which was by the side of a lake. I sent my present to the Gadado, to carry on his camels, as all that was now left me was a bullock with the itch, which we could hardly drive along, with only the tent, my servants carrying the rest. All that I had to eat was a little ground Indian corn, boiled with salt and water; and I slept in the open air.

'The governors of the several provinces had each a singing or crying man, in addition to the drums and horses. The one of Zegzeg was the most disgusting, being a large black man, mounted on horseback, with an unshaven head, roaring out like a person in great agony, and every now and then screaming out as loud as he could bawl, and calling me a Kaffir, threatening to eat me. In the morning, at an early hour, I left our place of encampment; and ascending a gravelly ridge, I had an extensive view to the west and south-west, over the extensive plains and swamps of Gondamie. The soil on the ridge was a red clay and gravel, the trees low and stunted. At noon, halted for the bullock to rest; and at 1 P. M. got him to move on again. At 5 P. M. halted on the borders of a large lake, which is formed by the rivers Zurmie and Zarrie-or, more properly speaking, a chain of lakes and swamps, extending through all, or the greater part of, the plains of Gondamie, ap- 
proaching nearly to Soccatoo. The borders of these lakes are the resort of numbers of elephants and other wild beasts. The appearance at this season, and at the spot where I saw it, was very beautiful; all the acacia trees were in blossom, some with white flowers, others with yellow, forming a contrast with the small dusky leaves, like gold and silver tassels on a cloak of dark green velvet. I observed some fine large fish leaping in the lake. Some of the troops were bathing; others watering their horses, bullocks, camels, and asses : the lake as smooth as glass, and flowing around the roots of the trees. The sun, on its approach to the horizon, throws the shadows of the flowery acacias along its surface, like sheets of burnished gold and silver. The smoking fires on its banks, the sounding of horns, the beating of their gongs or drums, the braying of their brass and tin trumpets, the rude huts of grass or branches of trees rising as if by magic, every where the calls on the names of Mahomed, Abdo, Mustafa, \&c., with the neighing of horses and the braying of asses, gave animation to the beautiful scenery of the lake, and its sloping green and woody banks.

The only regulation that appears in these rude feudal armies is, that they take up their ground according to the situation of the provinces, east, west, north, or south ; but all are otherwise huddled together, without the least regularity. The man next in rank to the governor of each province has his tent placed nearest to him, and so on. I always found out my quarters, which were close to the Gadado, by inquiring what province the people belonged to.

In the evening, the governor sent me a present of a sheep, and directly afterwards ordered a musquet to be brought to me, that I might put a screw to its lock; and on my declaring that I had no screws, and could not make one, his people went off rather dissatisfied, and shortly afterwards I missed my powder horn, which was hanging, with my gun and sword, to the branch of a tree: the rascals had stolen it. 
I now was informed, for the first time, by the Gadado, that before we went to Soccatoo, we should have to go by Coonia, the capital of Goobur, near which the sultan Bello was then encamped, with the forces from Soccatoo; and which place they intended to take before they returned to Soccatoo. The Kano troops are considered to be the best, and found to be more orderly than any of the others, but, on the whole, they are the poorest, and the most inefficient I ever saw, or could have imagined.

Saturday, 14th.-Morning cool and clear, but a heavy dew had made me quite wet and chilly. At 5. 40 A. M. left our encampment, the path generally skirting along the banks of the lake. Saw the traces of elephants every where, and last night the lions were roaring close to the camp. The heat of the sun from nine in the morning to three in the afternoon was the most oppressive I had ever felt it; and the dust raised by the number of men, and animals all pressing forward as hard as they could, made the air at times quite suffocating; and now that we are supposed to be surrounded by enemies, it is who shall be foremost: no halting is allowed. My servant, with a load on his head, was obliged to lead on the fatigued bullock; and $\mathbb{I}$, with another servant, managed to drive it along at a quick pace, but not without incessant beating, which, in a country like ours, famed for its humanity, would have appeared extreme cruelty; but a man will do many things here in Africa, that his humanity would revolt at in our more happy country.

At 4.40 P. M. halted along with the camp, fatigued and lowspirited; for what with the loss of my horse and camel, and what is still worse than all, my books and journal, leaving me only some loose paper and a pencil; when I beheld my servants carrying loads on their heads, and myself assisting and encouraging them to drive beyond its speed a poor scabbed and worn out bullock along the road; and when I have no prospect before me, but to subsist on water and boiled Indian corn, I cannot but feel a disposition to 
despond; but I trust things are now at the worst. Our place of halting was on the banks of a creek branching from the lake, very low and wet. My consolation is, that Bello is not at a great distance from us, and has sent to-day to ask after my health, and how I stood the fatigues of the journey.

Sunday, 15th.-Moming clear. At 5. 45 left our encampment, and at 9 arrived at a spot in the swampy wood where a stream of water was running through it. We had to cross this stream, which was about twenty yards in width, the banks steep, and water deep, appearing as if it had been artificially cut for a canal. We crossed it without accident, though many of the party, with their camels, bullocks, horses, and baggage, crowding together, were seen sticking in groups in the boggy swamp. I had not gone many paces on the other side before my horse sunk to the belly; and as I did not immediately dismount, thinking to ride him through, I got severely hurt on the pommel of the saddle, by his plunging. At last I got off, put the saddle on my head, and got him to a firmer spot under a tree; close to which, I found my servants endeavouring to drag the bullock out of the place where he also had sunk. I sat as a guard over my baggage; but all the exertions of my people could not get the poor ox out, and I called them off to rest, sending one to the camp for assistance.

In the mean time, some of the people of Zamfra, coming post without loads or arms, were on their way to assist their friends, who were sticking in the mud, and to drag the governor's baggage out of the swamp. I asked them, in a good-natured way, to lend a hand to help out my bullock, that was still sticking in the bog. "Well," say they, "christian, give us that meat you have got in your dish, and we will assist you." "Take it," said I, "my lads;" and giving them the sheep's heart, which was boiled and covered with fat, they divided it among them; and going to the spot where the unfortunate bullock was, had him out in an instant.

After letting the bullock breathe a little, we started again, but 
had new difficulties to encounter. There was a second stream to cross, worse than the former: I stripped, and waded over, leading my horse. On the other side, under a tree, I found a sick Fellata unable to move, with a burning fever, a native of one of the neighbouring villages; his friends, he said, had taken away his horse, and left him there, to the mercy of whoever might choose to assist him.

About mid-day arrived at the court of Bello; the Gadado saw me passing to my quarters, and sent to request I would halt, and to say I must go to the sultan, who would excuse every thing about my dress, as he was so anxious to see me. I accordingly dismounted, and accompanying the Gadado, we were instantly shown into the residence of Bello, which was formed of a number of huts, screened off by cloth fixed to poles, making quite a little village of itself. His reception of me was most kind and gratifying; he asked after the health of the king of England, and if we were still at peace, and how I had found all my friends. He was surprised when I said I had not seen them, and that I had remained only four months in England. He said, he had not received either of my letters, the one from Bornou, or that which had been sent by the way of Ghadamis from Tripoli. He asked me if I had not experienced a great many difficulties in getting through Yourriba; said he had heard of me when I was at Eyeo or Katunga, and that he had sent a messenger to that place, to assist me in getting through; and had also sent another to Koolfu; but neither of whom, as I told him, had I seen.

During this interview, it began to rain, thunder, and lighten very heavily; but as he and the old Gadado remained exposed to it, I was of course obliged to do so too. He had heard, he observed, that our camels had died on the road, but said he would send one of his men with a camel this evening, and who would take care that all my baggage should arrive safely at Soccatoo; but that it would be better that every thing should remain with me, until my 
setting out for the capital, where I could then deliver to him the present, and the king of England's letter, as he intended making an attack on the capital of Goobur on the morrow. The rain having now ceased, I was permitted to take leave, and made the best of my way to that part of the camp assigned to me, which was not far distant from the sultan's abode.

During the night, a pretty strict guard was kept, by horsemen in quilted armour; and all the horses in the camp were saddled at sunset, and remained so during the night.

Bello's appearance was very little altered from what it was when I saw him last, except that he had got a little lustier, and dressed somewhat better. He was dressed to-day in a white striped muslin shirt and turban, and the finest tobes that the country produces.

Monday, 16th.-Morning clear, with a heavy.dew. At 4 A.M. all was ready for commencing the war; but it was six before they started; the intermediate time being spent mostly in praying. I kept close to the Gadado, as it was his wish I should do so. Our path was through the plantations of millet and dourra of the enemy. At 8, the sultan halted under a tree, and gave orders for a camp to be formed, which was speedily done by the troops, cutting or pulling up the millet and dourra, and making huts, fences, and screens of the stalks. I waited on the sultan, who was dismounted, and sitting under the shade of the tree, near which he had halted. He was surrounded by the governors of the different provinces, who were all, with the exception of the governor of Adamawa, better dressed than himself.

After the midday prayers, all, except the eunuchs, camel drivers, and such other servants as were of use only to prevent theft, whether mounted or on foot, marched towards the object of attack; and soon arrived before the walls of the city. I also accompanied them, and took up my station close to the Gadado. The march had been the most disorderly that can be 
imagined; horse and foot intermingling in the greatest confusion, all rushing to get forward; sometimes the followers of one chief tumbling amongst those of another, when swords were half unsheathed, but all ended in making a face, or putting on a threatening aspect. We soon arrived before Coonia, the capital of the rebels of Goobur, which was not above half a mile in diameter, being nearly circular, and built on the bank of one of the branches of the river, or lakes, which I have mentioned. Each chief, as he came up, took his station, which, I suppose, had previously been assigned to him. The number of fighting men brought before the town could not, I think, be less than fifty or sixty thousand, horse and foot, of which the foot amounted to more than nine-tenths. For the depth of two hundred yards, all round the walls was a dense circle of men and horses. The horse kept out of bow-shot, while the foot went up as they felt courage or inclination, and kept up a straggling fire with about thirty muskets, and the shooting of arrows. In front of the sultan, the Zegzeg troops had one French fusil: the Kano forces had forty-one muskets. 'These fellows, whenever they fired their pieces, ran out of bow-shot to load; all of them were slaves; not a single Fellata had a musket. The enemy kept up a sure and slow fight, seldom throwing away their arrows until they saw an opportunity of letting fly with effect. Now and then a single horse would gallop up to the ditch, and brandish his spear, the rider taking care to cover himself with his large leathern shield, and return as fast as he went, generally calling out lustily, when he got among his own party, "Shields to the wall!" "You people of the Gadado, or Atego," \&c., "why don't you hasten to the wall?" To which some voices would call out, "Oh! you have a good large shield to cover you !" The cry of "Shields to the wall" was constantly heard from the several chiefs to their troops; but they disregarded the call, and neither chiefs nor vassals moved from the spot. At length the men in quilted armour went 
up "per order." They certainly cut not a bad figure at a distance, as their helmets were ornamented with black and white ostrich feathers, and the sides of the helmets with pieces of tin, which glittered in the sun, their long quilted cloaks of gaudy colours reaching over part of the horses' tails, and hanging over the flanks. On the neck, even the horse's armour was notched, or vandyked, to look like a mane; on his forehead and over his nose was a brass or tin plate, as also a semicircular piece on each side. The rider was armed with a large spear; and he had to be assisted to mount his horse, as his quilted cloak was too heavy; it required two men to lift him on; and there were six of them belonging to each governor, and six to the sultan. I at first thought the foot would take advantage of going under cover of these unwieldy machines; but no, they went alone, as fast as the poor horses could bear them, which was but a slow pace. They had one musket in Coonia, and it did wonderful execution, for it brought down the van of the quilted men, who fell from his horse like a sack of corn thrown from a horse's back at a miller's door ; but both horse and man were brought off by two or three footmen. He had got two balls through his breast; one went through his body and both sides of the tobe; the other went through and lodged in the quilted armour opposite the shoulders.

The cry of "Allahu Akber," or, "God is great," was resounded through the whole army every quarter of an hour at least (this is the war-cry of the Fellatas); but neither this, nor "Shields to the wall," nor "Why don't the Gadado's people go up," had any effect, except to produce a scuffle among themselves, when the chiefs would have to ride up and part their followers, who, instead of fighting against the enemy, were more likely to fight with one another. There were three Arabs of Ghadamis in the army, armed at all points. Hameda, the sultan's merchant, was one. He was mounted on a fine black Tuarick horse, armed with a spear and 
shield, an Arab musket, brace of pistols, blunderbuss, sword and dagger. The other two, Abdelkrim, and Beni Omar, armed with musket, pistols, sword, and dagger. Abdelkrim was mounted; Omar on foot, who received a ball from the Coonia musket, which carried away his cartouche box, with all his ammunition, early in the attack. The other two, Hameda and Abdelkrim, kept behind the sultan and Gadado the whole of the action, and always joined lustily in the cry of "Allahu Akber." Once Hameda asked me, when I was near him, why I did not join in the cry: was it not a good place? I told him to hold his peace for a fool : my God understood English as well as Arabic.

The most useful, and as brave as any one of us, was an old female slave of the sultan's, a native of Zamfra, five of whose former governors she said she had nursed. She was of a dark copper colour. In dress and countenance very like one of Captain Lyon's female Esquimaux. She was mounted on a long-backed bright bay horse, with a scraggy tail, crop-eared, and the mane as if the rats had eaten part of it; and he was not in high condition. She rode a-straddle; had on a conical straw dish-cover for a hat, or to shade her face from the sun, a short dirty white bedgown, a pair of dirty white loose and wide trowsers, a pair of Houssa boots, which are wide, and came up over the knee, fastened with a string round the waist. She had also a whip and spurs. At her saddle-bow hung about half a dozen gourds, filled with water, and a brass basin to drink out of; and with this she supplied the wounded and the thirsty. I certainly was much obliged to her, for she twice gave me a basin of water. The heat and dust made thirst almost intolerable. Numbers went into the shade as they got tired, and also to drink at the river. When it drew near sunset the sultan dismounted, and his shield was held over him for a shade. In this way we continued until sunset, when the stitan mounted. We left the walls of Coonia for the camp. 
Upon the whole, it was as poor a fight as can possibly be imagined; and, though the doctrine of predestination is professed by Mahomedans, in no one instance have I seen them act as men believing such a doctrine. The feudal forces are most contemptible; ever more ready to fight with one another than they are with the enemy of their king and country, and rarely acting in concert. During the night we were cut off from water by the inhabitants of Coonia, and a cry was raised that they had come out to attack us, when the whole of the forces of Zamfra, horse and foot, were tumbling over us in our quarter, pell-mell, who should get the soonest out of danger. I had not undressed, but had my horse saddled, and the camels loaded. My servants would have run too, but I made them stop and load the camels, when I sent them off with those of the Gadado, which now only remained.

The flags of the Fellatas are white, like the French, and their staff is a branch of a palm. They are not borne by men of honour, but by their slaves. 'The sultan had six borne before him; each of the governors had two. They also all dress in white tobes and trowsers, as an emblem of their purity in faith and intentions.

Tuesday, 17th.-Morning clear, with a heavy dew. We were last night disturbed several times by reports of the enemy's approach; and at one time so great was the confusion, that most of the people and animals of the camp were tumbling over each other, and rushing together to save what they could by flight. The forces of Zurmie, who were encamped nearest the town, fled through the general camp, upsetting every thing in their way. My servants would have followed, but I declared, if they started without the baggage, I would shoot them. This threat, and my seizing the rifle to put it in execution, had the desired effect. I ordered them, however, to load the camels, after which I allowed them to go off, along with the camels of the Gadado. They begged hard 
that I would go with them; but I remained until the Gadado and the sultan departed; and thus ended this harmless campaign, for at five in the morning both he and the Gadado set out, and at seven halted where we had suffered so much fatigue in getting through the swamps two days before. Here the south and eastern governors took leave of the sultan, and pursued the road we had come with them the other day, while I remained with the Soccatoo party. Our road lay once more along the banks of the lake. Numerous tracks of elephants, and other wild beasts, were every where seen. The face of the country, on the higher grounds, was but thinly wooded, and the trees low and stunted, except in the ruins of towns, where they usually grow to a large size, and very luxuriant in foliage. No traces whatever of inhabitants. The sun was excessively hot; and only for the plentiful supply of water the lake afforded, we certainly must have died of thirst. At 7 A. M. halted at an old encampment of the sultan.

I now, for the first time, learnt the cause of our rapid flight, which was the desertion of the Zurmie forces, and all the foot; who had started on the first alarm, as they were all aware that the horse would not wait for them. I passed a number of the foot who were wounded, a very few of whom had been fortunate enough to procure bullocks to ride on. 'The rest were poor slaves, and were obliged to walk. One poor fellow had been wounded in the night, attempting to get water, for they had been cut off from the supply of that necessary article. The night we attacked the town, his face had been laid open by a sword, and he had received a severe wound in the arm. His wounds were much swollen, as they were exposed both to the sun, and the cold of the night; and only tied up with a bandage or slip from the inner bark of a tree, which did not cover one half, or a third of the wound.

Wednesday, 18th._At 2. 30 we left our encampment, and, 
half running, half walking along the Soccatoo road, which still skirts the banks of the river or lake, no appearance of inhabitants to be seen, passed the ruins of three towers; and the traces of elephants and other wild beasts were numerous: the soil a deep red clay, mixed and covered with a thin layer of sand. At 2 saw a range of hills extending from south-west to north-east, not of great elevation ; as we approached them, the lakes and swamps took a direction to the southward; the soil became clay and gravel, with rocks of clay iron-stone on the surface. At 5 we got amongst the ravines, and beds of torrents at the foot of the hills, and turning to a bend in the hills south, kept winding amongst them, fatigued and tired, until 10 the next morning, when $I$ haited at one of the Fellata's former encampments. I passed many walking on foot, driving their horses before them, and for several miles before I came to the camp, the foot, some of whom we had now come up with, were lying along the road, unable to move further. My camels, which had got amongst the first, had halted two hours before. Thursday, 19th.- The road still lay over hills of clay iron-stone, imbedded in a dark red clay, for about four hours, when we arrived on their south-west side, where we had to pass about a mile and a half of low swampy ground, before we came to the Zurmie river, which was here broad, full, and running with a current of about two miles and a half an hour to the westward; its depth at the ford about five feet, its breadth about sixty yards. As usual, there was a great assemblage of horses, camels, bullocks, and asses, and of course great confusion, every one striving to drive before the others. I stripped, and taking the bridle of my horse, plunged in, and drove him on before me. I got a severe head-ache, as the water was very cool, and I was warm. I lay down, after I had dressed, under a tree on the other bank, until the camels had fed a little, when I started again. The river below forms a chain of lakes and swamps, skirting 
the south-west sides of the hills. Our road lay through plantations of cotton and millet. The sides of the road were crowded by the foot, with whom we were now come up. 'They looked miserable in the extreme from hunger and fatigue: a great many of the horsemen were walking, driving their poor goaded animals along.

At noon I arrived and halted at Magaria, a stragghing town built among the hills, which was now a second range closing in to the north. This town is the sansan, or gathering place for their armies, and is mostly inhabited by the slaves of the great in Soccatoo, who have all houses here, and their slaves, who are employed in raising grain, and tending the cattle, mostly reside here, and in the villages around. 'I'he swampy plain, the river, and the lakes, extend about six miles to the westward, below Magaria; and from its situation in the gap of the hills must be very unhealthy, from the north-east winds driving the vapours right through the town, which, in fact, is situated on the borders of the swamp.

Morning clear. At 7 left Magaria, the Gadado and sultan having sent to me the evening before, to say, if I wished to go to Soccatoo and remain there, until they joined me, I might do so ; as they intended to stay for some days in Magaria, to see if the enemy was disposed to make an attack on them. I availed myself of this permission; indeed I had met with nothing but losses and difficulties since I had joined the Fellata army. I therefore set out, and passed over a fertile country. Every spot capable of cultivation was planted with millet and dourra, which was in fine condition. In this district, they had a scarcity last year, and the year before, and many of the people had perished for want.

After crossing the hills, which were composed of loose pieces of iron clay-stone, covered with sand, to the depth of a foot, I arrived at the river which runs close to the foot of the ridge or hill on which Soccatoo stands. The banks were crowded with people 
fishing. Their nets were formed like a bag, having a border of two small wands, which they held on each hand, to open the bag. The fish they caught were small white ones, which are usually carried to the market fried in butter, and sold at two cowries a-piece.

At 3 I entered Soccatoo, and took possession of the same house I formerly inhabited; the Gadado having sent a messenger before me, to make every thing ready for my reception, and to provide for all my wants. 


\section{CHAPTER VI.}

RESIDENCE AT SOCCATOO, TILL THE DEATH OF THE AUTHOP.

Shortuy after my arrival at Soccatoo, I was visited by all the Arabs of the place, who began to pay me a great many compliments, and after that, to beg every thing they saw in my possession. They immediately recollected my servant, Mahomed El Siekis, who was formerly a slave of Bukhaloom, and the only one of his army who brought off the flag of the bashaw of Tripoli, at the battle with the Fellatas at Musfeia ; and the same man who restored Major Denham his horse, when he thought he had lost it in that action. I had found this man a slave to a Fellata, in the town of Korfu, and bought him for 25,700 cowries, and gave him his liberty. These villains of Arabs now advised him to leave me, because I was a Christian; telling him that they would maintain him. I told him he was at full liberty to go, when and where he pleased; that he was now free, and no longer a slave : but I advised him not to go away like a thief and abscond, but to leave me boldly and openly; at the same time I desired him only to look at the dirty and ragged tobes of his advisers, poor rascals, who were not able to buy soap to wash themselves or keep their clothes clean, still less to give him food, wages, and clothes as I did.

On taking a survey of Soccatoo, I was not able to see much, if any, alteration in its buildings, though I understand it was nearly consumed by fire last winter, said to be the work of the rebels of 
Goobur; who, as the morning breezes at day-break come strong from the north-east, set fire to one house in that quarter, which spread rapidly, and consumed nearly two-thirds of the town before it could be stopped. It is now rebuilt just as it was before. There are at present eleven gates into Soccatoo; seven having been built up since the breaking out of the rebellion.

There are ten cadies or judges, who, with old Ben Gumso, an Arab living here, whenever the sultan leaves the city, keep watch at the gates day and night, with their people, until his return. Each takes a gate, and has a temporary house of matting, built close inside to live in. Ben Gumso, on my arrival, sent to tell me where he was stationed, and that he could not come and see me, until the sultan should return, as the punishment for leaving his post would be death. I accordingly went to see him. He was standing at the door of his house; he had seven crazy Arab muskets, some of them without flint or ramrod; but, notwithstanding all this, his post, on account of the muskets, was considered impregnable.

'Tuesday, 24th.-In the afternoon a messenger arrived from the sultan and the Gadado, to inform me that, as the rebels were daily expected near Magaria, they did not know when they would be able to return to Soccatoo. They therefore wished me to return to that place, and remain with them, and sent two camels to carry my baggage, and a horse for myself. The report here is, that the inhabitants of the neighbouring villages near Magaria have all fled, and taken up their quarters there.

Wednesday, 25th.- I did not start for Magaria to-day, as I had to lay in a stock of rice, bread, dried meat, and flour, as these articles are much dearer in Magaria, and bread not known. Magaria is in the province of Adir, which is also called Tadela, containing a great number of towns. The inhabitants are for the greatest part negroes. The rest are a half breed between the 'Tuarics and

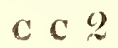


their slaves. The country is full of low rocky hills, and is well watered by lakes and streams.

Thursday, 26th.-Morning cool and clear. At 8 A. M. I left Soccatoo for Magaria. I was ill with a severe cold, caught by my own carelessness, in throwing off my cloth trousers and worsted stockings on my arrival at Soccatoo. The sun being very hot, I was quite feverish. I halted at a village till 3 P. M., when I started again, and arrived at Magaria at 6 P. M., where a house had been prepared for me. I had messages from the sultan and Gadado, to inquire after my health. My spleen was considerably increased in one day; but $I$ went to bed without tasting food: had a fire made at my bed-side, which procured me a good sweat, and I soon found myself better; though not lessening the swelling in my side, it eased the pain, as also the pain in my head and bones.

Friday, 27th.-Cool and clear. I found myself much relieved; and the Gadado, paying me an early visit, said, if I was able, the sultan would receive his majesty's letters and presents. I immediately dressed in my uniform, and the presents being ready packed in separate parcels, the time-piece, watch, \&c. taken out of the tin cases, and all just as they had left the maker's hands, I went, accompanied by the Gadado, my servants and the servants of the Gadado carrying the presents, consisting of red silk umbrella, silver mounted; a message cane, silver mounted; twelve yards red damask; twelve yards sky blue; twelve yards red silk; twelve yards blue silk; twenty-four yards cambric; two pounds cloves; a fowlingpiece, brass mountings, single barrel; a plain fowling-piece, double barrel; a pair of pistols for his eldest son; two short swords; two boxes of rockets; a quantity of powder, balls, flints, and small shot; one ream of English foolscap paper; two bundles of black lead pencils; coloured prints of the royal family, battles, and a plain journal book; a small ditto; a dozen pair white cotton stockings; a dozen pair white cotton gloves; a time-piece by Rigby; 
gold watch by ditto; a Bramah pen; a pistol, detonating lock; two gilt chains; four clasp knives; a dressing-case complete; a magnifying looking-glass; two English bridles; a quantity of medicines; two empty trunks; the New Testament in Arabic; that part of the Old Testament which was translated; the Koran in Arabic ; Euclid's Elements in ditto ; Ebn Senna in ditto ; History of the Tartars under Tamerlane ; Psalms of David ; several chapters of the Bible, with a number of other books in Arabic. To the Gadado a smaller collection of the same kind of articles.

Saturday, 28th.-I was visited this morning by Sidi Sheik, Bello's doctor, and one of his secretaries, who said he had a message from the sultan for me, which, on his delivery, certainly surprised me not a little, though I was cautious not to show him that I considered it as any thing but a thing of course. It was this, that the sultan had sent him to inform me that, by whatever road I might choose to return to England, he would send me, were it even by Bornou, if I should prefer that road; but that I should consider well before I decided upon that road, as he had to inform me that, when I was here two years ago, the Sheik of Bornou had written to him, advising him to put me to death; as, if the English should meet with too great encouragement, they would come into Soudan, one after another, until they got strong enough to seize on the country, and dispossess him, as they had done with regard to India, which they had wrested from the hands of the Mahometans : that Bello, however, had said, in reply, it would be a most disgraceful thing in him to cause an unprotected man to be put to death, and could only account for such conduct, on the part of the Sheik, after he himself had placed me under Bello's protection, to seek a quarrel between him and the Sultan Bello.

I observed to Sidi Sheik, that it was certainly very extraordinary to me, that the Sheik El Kanemi should have written in such a manner; as he had ever behaved to me with the greatest kind- 
ness, both before I came to Soudan and on my return; and that, when I left Bornou for England, he had dismissed me with a handsome present, and the strongest expressions of friendship and regard. I added, that I must insist on seeing this extraordinary letter, and have a copy of it; but he said that Bello had sent the letter to Gondo, to his cousin Abdallah. I must positively see it, I rejoined ; and also be allowed to take a copy of it before I leave this place; for I lad a letter and presents from the king of England for the Sheik. I then asked him what other path the sultan proposed. He replied that he would place me under the protection of a maraboot, or holy man, who would safely conduct me to the sultan of Borgoo, and from thence I might pass to the northward, as far as the borders of the desert, and proceed along it until I came near to Foutoo Tora, from whence I could turn to the southward into a country that belonged to Bello, and which was inhabited by Fellatas, and not far from one of the English settlements. I told him it was a matter of serious consideration to me, as I had a sick servant at Kano, who was unable to travel; but, at all events, I must have the letter the Sheik of Bornou had sent to Bello.

I was very ill all day; but in the afternoon I paid a visit to A tego, Bello's brother, and made him a present of a gilt chain and a pair of scissors, and a few cloves. His house being at some distance, I was so much fatigued I thought I should not live until the morning.

Sunday, 29th.--Saw the sultan this morning, who was sitting in the inner apartment of his house, with the Arabic copy of Euclid before him, which I had given to him as a present. He said that his family had a copy of Euclid brought by one of their relations, who had procured it in Mecca; that it was destroyed when part of his house was burnt down last year ; and he observed, that he could not but feel very much obliged to the king of England for sending him so valuable a present. After a few general questions, I retired 
with the Gadado; and when we arrived at his house, and were seated, I again expressed my anxious desire that he would give me a copy of the letter which had been sent from the Sheik of Bornou, as it was of some importance to me to be guided as to my choice of the road I was to take on my return home. The Gadado said he was not aware of any letter having been sent; that it was very wrong in Sidi Sheik to have told me such a story; said he must have made a mistake; but, to relieve me from any uneasiness on that score, he would inquire into the truth, and let me know to-morrow.

Monday, 30th.-I had been so ill all night with the pain in my side that I had no rest whatever. At noon the Gadado came to say that he would go with me to the sultan. Though very ill, I went; and we were immediately shown into the apartment of the sultan, who was reading: but when we entered, he laid down his book, and began of his own accord about the letter. He observed, that a letter had certainly come to him, but not with the Sheik's signature; that it appeared, however, the letter had been written, with the Sheik's sanction, by that holy man Hadgi Mohamed Bootabli; and that he was desired to say I was a spy, and that he would not allow me to go beyond Soccatoo; hinting, at the same time, that it would be better I should die, as the English had taken possession of all India by first going there by ones and twos, until we got strong enough to seize upon the whole country. And thus ended our interview.

Tuesday, 31st.-I was much better this morning, and the swelling and pain in my side much less, a dose of calomel I took having done its duty; but I thought it advisable not to stir out all day. The sultan and Gadado sent to me to know how I was.

Wednesday, Nov. 1st.-Clear. Magaria is now increasing to a town of considerable size. Before, it was without shape or form; now, all the people from the villages, for a considerable distance around, have been ordered to live here; and the houses being pro- 
perly arranged, each man's cluster of huts being fenced round with matting, nearly all the vacant places are filled up with houses or enclosures for cattle. A new wall has been built, according to the present Groobur mode of fortifying a town; which is, to build a low wall, with a deep ditch outside, and to erect on the wall a stockade of rough stakes, firmly fixed in an upright posture, through the openings of which the people inside are enabled to shoot their arrows and fire muskets, when they have any. 'This new wall was not quite completed when I arrived; but as every man having a house in the town was to bear his part in the work, and every man of consideration who held office under the sultan was to superintend that part of it next to his residence, as well as to employ his slaves and servants in bringing wood and materials, the progress advanced rapidly.

This evening we had a courier from the nearest town in the province of Zamfra, bringing intelligence that Aleva, the rebel sultan of Goobur, had died by an arrow wound in his side, which he received when we made the attack. Whether this will have any effect in bringing about a reconciliation with Bello and them I know not.

Thursday, 2d.- Warm, with light flying clouds. The Juma, or place of worship, in Magaria, is only a temporary one. I have had several opportunities of seeing them at prayers, being only a square enclosure of matting, supported by stakes, and open on one side, which is to the east. The Iman, or priest, a head man, stands at a little distance in front, on his mat; the rest of the people in rows behind him. He repeats the prayer, and those behind him also repeating inwardly at the same time, and with the greatest regularity, in a kneeling posture, with their heads inclined.

I had a long visit from Prince Atego this morning, who was amazingly civil: at last it came out that he was afflicted with a disorder which he represented as being very common in this country. 
I recommended him to drink rice water in plenty, to refiain from pepper and strong spices, and not to visit his ladies too often, and to wear a hat when he rode out. I also gave him a dose of calomel, recommending him to use natron in his food.

The henna or salli, with whose leaves they stain their hands and toes, is made of pounded leaves, mixed with water to the consistence of a poultice, which is laid on thick, and bound with gourd leaves to keep it on. To see a person in this state, without knowing that he was sacrificing comfort to make himself look beautiful, would be apt to excite pity for the poor man, and to imagine that he had fallen from some height, and bruised his hands and feet so badly as to require their being poulticed to reduce the inflammation. Some great people go so far as to have themselves stained every three nights.

Friday, 3d.-The negroes and most of the Arabs are great gamblers, though it is strictly prohibited by the Fellata laws. Their principal game is called cha-cha, and is played by any number of persons at a time, with cowries. Night is the usual time for this game; and so eager are they in it, that they will frequently stake their breeches and every part of their dress. I should never have known of its existence, had not one of my servants, named Micama, a native of Zinder in Bornou, come home last night with the loss of his tobe; and on my insisting this morning that he should not enter the house in such a state, he pleaded the heat of the weather, and made other excuses, which I could not allow: the other servants then told me what he had been at, and said he was an expert hand, and could not refrain from playing when he saw others play. I advanced him money to buy another tobe, telling him if I ever knew him to play again, I should give him up to the Fellatas, who punish all caught at such a game with death, or something approaching it. In the afternoon I took leave of the sultan, who breaks up in the night, and proceeds to Soccatoo. 
Saturday, 4th.-Morning cool and clear. The sultan did not leave last night, but to-day at 3 P. M. I had to go and see the chronometer carefully put up to bear carriage without injury: it is considered the most valuable part of his property, and numbers come from a great distance to hear it strike. One of the gold watches he has already spoiled, and I have had to give his brother Atego my silver watch for it in return, but I have got the worse bargain. If the sultan had not asked me I should never have done it, as it has the new patent key, and kept a regular rate from England.

Sunday, 5th.-I did not start this morning, as I had been very unwell all night: got a new camel, and employed a Tuarick to buy me another, as they are nearly 2000 cowries cheaper here than they are at Kano.

Monday, 6th.-Cool and clear. At 6 A. M. left Magaria. I rode my new camel, as his load was light, and I had no horse. At 11 A. M. halted at a spring for an hour, and started again at 2. Arrived at Soccatoo.

Tuesday, 7th.-This day I visited the sultan about noon, and, at his request, taught a man, one of his servants, how to wind up the time-piece, which is one of eight clays. In the afternoon I was visited by three Fellatas, Hadji Omer from Foota Tora, Malem Mahomed from Timbuctoo, and the third from a neighbouring town to Timbuctoo. Malem Mahomed says the whole of the district called Timbuctoo is at present under the authority of the Tuaricks; that the principal town is called Timbuctoo; and that their gold comes from Ashantee, Gonga, and Bambarra, where they exchange it for salt to the Tuaricks, and cloths to the inhabitants of Fez, Ghadamis, and Tripoli ; that Timbuctoo produces no gold, it being only the great market where all the gaffles from the north and east meet those of the south and west; that few Arabs now come from Fez and Morocco, owing, he says, to the Arabs, called Waled Dleim, cutting off the caravans. 
Hadji Omar, who was an intelligent man, told me that forty men arrived at Sego with the late Mungo Park. That, out of the forty, thirty-five had died of sickness, and that five only embarked in the canoe given to him by the sultan of Sego. That they were repeatedly attacked by the Tuaricks, of whom they killed a great number. Whether any, or how many, of those belonging to the canoe were killed, he could not say. The Hadji had just returned from Mecca, and wished to go there again, if he could get an opportunity; but, as he said the sultan of Baghermi and his subjects had been driven into the mountains to the south of that kingdom by the Sheik el Kanemi, there was no passing through that country, as it was now only inhabited by wandering Arabs, who plunder all that fall into their hands, otherwise it was the best road to the east from Adamowa, by the way of Baghermi.

Friday, 10th.-For the two last days I have found myself very ill, with an enlargement of the spleen. Soccatoo was built by Sheik Othman, usually known by the name of Danfodio, or the learned son of Fodio. He was a good linguist; and knew most of the languages of the interior, which he spoke fluently, and also all the dialects of the Arabic. He knew all the learning of the Arabs; and, what was of the greatest importance to him, was firmly believed to be a prophet; and the belief continues, getting stronger as the Fellatas get stronger. He came out of the woods of Ader, or Tadela, and settled, and built a town in the province of Goobur, where the Fellatas began to gather around him; he soon began to interfere with the affairs of the sultan of Goobur, saying this was proper to be done, and such a thing was improper. This not pleasing either the people of Goobur or the sultan, he was ordered out of the country, he and his people. This order he did not obey; and the people of Goobur rose and drove them out; when he again settled in Ader, not in the woods, as formerly, but built a town. Fellatas gathering round him from all the different coun tries, he divided them under 
different chiefs, giving each chief a white flag, telling them to go and conquer in the name of God and the prophet, as God had given the Fellatas the lands and the riches of all the Kaffirs, as they, the Fellatas, were the only true believers. In addition to the white flag, the Fellatas were to wear a white tobe, as an emblem of their purity, and their war-cry was to be Allahu Akber! or, God is great! That every one who was wounded, or fell in battle, was sure to gain paradise. 'Their belief in him as a prophet, their own poverty, numbers, and the apparent wealth of the blacks, who had been lulled into a fatal security, made the latter fall an easy prey to their conquerors. Kano submitted without a blow. The next was Goobur; the people of which had taken the alarm, and attempted to turn Danfodio out of his town in Ader, but they were driven back, and the wily old chief then attacked them, overran their country, and killed the sultan. After this the whole of Houssa, with Cubbé, Youri, and part of Nyffé, fell under their dominion. 'The whole of the interior, from east to west, was terror-struck. Bornou, in the east, was attacked with success, as was also Yourriba, in the west. Here they found more resistance than any where else, as they (the people of Yourriba) could not be made to believe in his doctrine or prophecy, as they were confirmed Kaffers, who, on the invasion of the Fellatas, put all the Mahometans to death, whether natives, or in caravans trafficking; quite denying the plea that God had given to the faithful their lands and houses, and their wives and children to be slaves. Notwithstanding, they took Rakal, Elora or Affaga, besides a great number of other towns, reaching to the sea coast, in their expeditions; and once entered Eyeo, or Katunga, the capital, a great part of which they burnt down, giving liberty to all the Mahometan slaves, and encouraging others to kill their pagan masters and join them. After they had fairly settled themselves, the Arabs from the east and west came to congratulate Danfodio on his newly acquired territory. 
Numbers of his countrymen came from the west to settle in Houssa. These he located principally in the province of Zegzeg, where he gave the lands and houses of the negroes who had fled to the mountains and inaccessible parts of that province lying to the south. To the Arabs of Tripoli and Fezzan he made large presents of slaves and camels, sending none away empty-handed. The news of his fame spread every way. Arabs, in shoals, came and passed with him as sherifs, and would seldom go away under a hundred slaves, with camels and provisions.

Before he gathered the Foulahs, or Fellatas, under his government, they did not live in towns, but were seattered over the greater part of Soudan, attending to their herds and flocks, living in temporary huts, generally in the midst of unfrequented woods, seldom visiting the towns. This business they left to the women, who attended the markets, and sold the produce of their cattle. The men were reported to live a religious and harmless life, spending a great part of their time in reading the Koran and other religious books. Now and then a few of their learned men would come forth, and engage themselves for a few years with the Mahometan sultans and governors, until they had collected a little money, with which they purchased a few cattle, and then returned to the woods to their countrymen, who moved about from one province to another, according to the seasons, and the nature and quantity of pasture and water; contented with building temporary huts of straw and rushes, and to be left in peace. No one indeed thought of disturbing them, or interfering with their pursuits, they being probably considered as too contemptible and insignificant to excite any fear. Thus dispersed, no one but themselves knew or could guess at their numbers. Melli, or the petty kingdoms of Foota-'Torra, FootaBonda, and Foota-Jella, were the places from whence they spread themselves eastward, until they became very considerable, in point of numbers, in all the countries between the above-mentioned 
places and Wady. Many of them had performed their pilgrimage to Mecca, and others had visited the empires of Turkey and Morocco, as also Algiers, 'Tunis, and 'Tripoli, bringing back with them all the Arabic books they were able to beg or buy.

In the year of the Hegira 1218, the old Mallem Sheik Othman Danfodio, Sheik of the Koran, became religiously mad, and is said to have died some years afterwards in that state. This Foulah or Fellata conqueror was styled Sheik of the Koran from his being perfect master of that book, not only being able to read it, and all the commentaries upon it, but also to repeat any part, and explain it, from memory. The laws of the Koran were in his time, and indeed continue to be, so strictly put in force, not only among the Fellatas, but the negroes and Arabs, and the whole country, when not in a state of war, was so well regulated, that it was a common saying, that a woman might travel with a casket of gold upon her head from one end of the Fellata dominions to the other.

His madness took a very unhappy turn. In the midst of a paroxysm, he would constantly call out that he should go to hell, for having put so many good Mussulmen to death. The Arabs used to take advantage of this, and tell him he was sure to be damned, unless he made amends by giving them presents to assuage the manes of their friends. Not so with the Fellatas. These people had so great a veneration for their chief that, when his head was shaving, the hairs were carefully collected, and preserved by them in cases of gold and silver, and they used to come from all parts of the interior to get a sight of him, negroes as well as Fellatas.

After his death, his son Mohamed Bello, the present sultan, governed the kingdom which his father had conquered; but that part of the country to the westward of Houssa he left to his brother's son, Mohamed Ben Abdallah, while the eldest, Mohammed Bello, had Haussa, with all the countries to the south and east. Atego, the brother of Mohammed Bello, both by father and 
mother, attempted to usurp the government of the latter, at the death of the Sheik Othman; but his brother put him down, and confined him to his house for twelve months; and they are now as good friends as before.

Bello extended the walls of Soccatoo, which is now the largest and most populous town in the interior that I have seen. Within these walls live all the children which Danfodio had by his different wives and concubines, very quietly and without splendour, except Atego, who is a mean fellow, but keeps a large establishment. At the death of Danfodio, in the year of the Hegira 1232 (in 1816 of ours), the province of the Goobur, Zamfra, part of Kashna, and Zegzeg, threw off the yoke of the Fellatas, and put the whole of them to death that they could lay their hands on. Since that time, Bello has retaken the greater part of Goobur; part of Zamfra, and Guari, the southern part of Kashna, have made their peace, as also part of Cubbé; but on this condition, that they shall be ruled by their native chiefs, and the Fellatas not to interfere with them. Since my arrival, he has also got back the greater part of Nyffé. Youri has, since 1822, joined in the rebellion, being forced by the people of Zamfra, who at all times can command that province, if not supported by Cubbé or Soccatoo. The governor is to be hereditary, not like most of the other provinces and kingdoms in the interior, where the oldest relation always succeeds.

The city of Soccatoo stands on the top of a low hill, or rising ground, having a river passing at a short distance from the northern wall. It is formed of the united branches of the several streams, which take their rise to the south of Kashna, and flow past Zirmie. Having passed Soccatoo, it crosses the district of Cubbé in a southwesterly direction, and at the distance of four days' journey enter's the Quorra. It is well stored with fish, which afford the poor people of Soccatoo a very considerable part of their food. 'The city is surrounded by a wall, about twenty-four feet high, and a dry 
ditch. 'The wall is kept in good repair, and there are eleven gates; seven having been built up at the breaking out of the rebellion. The clay walls which surround all African towns, clusters of huts, and even single coozies, give a deadly dull appearance to them all, whether negro or Mahometan. The only appearance of animation is given by the great number of slaves and others moving to and fro, or lounging, or lying in the shade at the doors of great men. A great part of the town within the walls might be taken for a number of ill-enclosed gardens.

'The house of the sultan is surrounded by a clay wall, about twenty feet high, having two low tower-like entrances, one on the east, the other on the west. The eastern one is entirely guarded by eunuchs, of whom he has a great number, I suppose because the harem is on the eastern side. The whole of his house forms, as it were, a little town of itself; for in it there are five square towers, a small mosque, a great number of huts, and a garden, besides a house, which consists of one single room, used as the place for his receiving and hearing complaints, receiving visitors, and giving audiences to strangers. This room or house is nothing more than what we should call in our country a shed. Two large pillars support a beam, or bundle of long rods, plastered over with clay. These support the rafters, which are of the branches of the palm-tree; on the back part is an imitation of a fire-place, with a fire-screen before it; and on each side are two chairs, which are also plastered with clay, and coloured like mahogany. The ornament or figure on the back of these is the same as those seen on a number of chairs in England, and corresponds with that on the firescreen. The walls are ornamented partly in the European and partly in the African fashion. There are two doors, one in the front towards the right, and the other in the left end of the house, and which leads through a small street of huts to a large hut, with two doors: passing through and within a few yards of it stands 
a large square clay tower, with an entrance in the west side. 'The interior of this is common in most of the great men's houses in Houssa. It is in the shape of a dome, formed of eight arches springing from the ground; in the centre of which is a large bright brass basin, acting as it were in the place of a key-stone to the arches, which are turned by branches plastered over with clay. If I had not seen them constructing the arches and pillars of a mosque, I should have supposed them to be formed entirely of clay, as the wood in no part appears. 'The clay serves to keep the white ants from destroying the wood; they are ornamented in their fashion while the clay is wet, an operation performed with the fingers and a small square stick. From the arches, about one-third up, runs a gallery quite round the interior building, having a railing with pillars of wood, covered and ornamented with clay. There are three steps leading up to this gallery, from which every thing in the dome may be seen or heard. Passages also lead from it into small rooms, having each one small window, or square hole, some appearing to be used as store-rooms, and others as sleeping-rooms. The floor of the dome was covered with clean white sand. The height might be, from the floor to the brass basin in the centre of the arches, from thirty-five to forty feet. The air inside of this dome was cool and pleasant; and Bello told me he often used it as a place to read in during the heat of the day. 'These two apartments are the only two I have seen deserving remark within his enclosure. One night that he sent for me, when it was rather late, I was led by the hand by an old woman through several apartments before I arrived at the one in which he was. As there was no light, I could only judge by the stooping, and ascending and descending through doors and galleries, that I passed through some large rooms, out of one into another.

The houses of the other great men, and those of his brothers, are nearly the same, but on a much smaller scale. A great number of the 
poorer sort are fenced round with matting, or the stalk of dourra or millet. Before the west front of the sultan's enclosure is a large open space, of an irregular form, on the west side of which stands the principal mosque. In this space is also the prison, a building of about eighty feet long, and nearly the same in breadth, covered at top with a flat clay roof, overlaid with boughs. Inside is a deep pit, where those who have committed the greatest crimes are confined. No person is put in prison for debt; only thieves, prisoners of war (taken singly), such as spies, and disobedient slaves, who, on a complaint to the sultan that they will not work, are sent to prison. 'Their only food is the bran or husks of millet and dourra, with water; but their friends are allowed to give them food, if they have any. It is a filthy place, and the terror of the men-slaves of Soccatoo. 'The prisoners are taken out, two and two, every day to work at the walls, or any laborious work which may occur.

Another house and the tomb of the sultan is further to the west of the mosque, on the north side of a broad street, which leads to the western gate. It is occupied by his widows, concubines, and youngest son, called Abedelgader, who is not arrived at a proper age to have a house for himself. The sheik's tent is inside of the square enclosure, behind the room he generally occupied when living. It is visited as a holy place by all Mahometan strangers, from which they afterwards hope to enjoy the good things of this world, and that of their world to come.

The ordinary occupations of the higher, and indeed I may say of all classes of the Fellatas is, they rise at day-break, wash and say their prayers, count their beads for about half an hour, and then chew a gora nut, if they have any; which done, they sip a quantity of senkie, or furro-furrocoo. These articles are a preparation of half-boiled dourra flowers, made into balls of about one pound, mixed up with dry flour. Senkie is one of these balls, bruised 
and mixed with milk; furro-furrocoo is the same kind of ball mixed with water. About $10 \mathrm{~A}$. M. they have rice boiled, which they eat with a little melted butter. After this they pay visits, or lounge in the shade, hear the news, say prayers, count their beads, which employ them till sunset, when they have a meal of pudding, with a little stewed meat and gravy, or a few small fish; they then retire to rest.

During the spring and harvest the proprietors of estates ride out to their different slave villages to look after their grain, cotton, indigo, \&c.; or to the place where they have their cattle. The occupations of the poorer class, who are not engaged in trade, are much the same as those of their superiors; their food is somewhat different, being principally confined to furro-furrocoo. The wives of the principal people, of whom they all appear to keep up the number allowed by the Koran, which is four, with concubines as many as they can get or are able to keep, are occupied in directing the female slaves in their work, cooking their husband's food, cleaning and spinning cotton, and dressing their hair, teeth, eyebrows and eye-lashes, which take up no little time. They also take charge of sending the female slaves to market to sell their spare cotton, grain, furro-furrocoo, millet, cakes fried in butter, fried fish, which are usually caught by the younger male slaves; in receiving or paying visits, for they are great gossips. They are allowed more liberty than the generality of Mahometan women.

'The dress of the men is a red cap, with a blue tassel of silk, a white turban, part of which, or a fold, shades the brow and eyes; another fold is taken over the nose, which covers mouth and chin, hanging down on the breast; a white shirt, close at the breast and short in the skirts, a large white tobe, and white trousers, trimmed with red or green silk, and a pair of sandals or boots: this is the dress of the greater part of the wealthy inhabitants. When travelling, they wear, over the turban, a broad-brimmed straw hat, 
with a round low crown. Some who do not affect great sanctity or learning wear check tobes and blue turbans over the forehead, with the end hanging down behind; the poorer, a white check tobe, white cap and trousers, and sandals. Some are content with the straw hat only, but all wear a sword, which is carried over the left shoulder. The women have a cloth striped with blue, white, and red, falling as low as the ankles ; silver rings in the ear, about an inch and a half in diameter, bracelets of horn, glass, brass, copper, and silver, according to the quality of the wearer; round the neck, beads, and strings of glass, or coral ; round the ankles, brass, copper, or silver, and sometimes rings on the toes as well as fingers. The fashionable ornament is a Spanish dollar soldered fast to a ring. The poor women have pewter, brass, and copper rings. The hair is generally turned up like a crest on the top of the head, with something like a pig's tail hanging down from each extremity, a little before the ears.

Some of the Fellata women have the hair frizzed out at the ends, all round the head; others have the hair plaited in four small plaits, going round the head like a riband or bandeau. 'This, and all the plaited parts, are well smeared over with indigo or shumri. The razor is applied to smooth all uneven places, and give a high and fine arch to the forehead; they thin the eye-brows to a fine line, which, with the eye-lashes, are rubbed over with pounded lead ore, and done by drawing a small pen that has been dipped in this ore. The teeth are then dyed with the gora nut, and a root of a shining red colour; the hands and feet, the toe and finger nails, are stained red with henna. A lady thus equipped is fit to appear in the best society. The looking-glass is a circular piece of metal, about an inch and a half in diameter, set in a small skin box, and is often applied to. 'The young girls of the better sort of people dress much in the same manner as their mothers, after they arrive at the age of nine or ten; before that, they have 
very little dress, except the binta or apron, scolloped or vandyked round with red cloth, with two long broad strings vandyked round in the same manner, hanging down as low as the heels behind. This is the dress of the poorer sort of people, until fit for marriage, as also of a great many of the virgin female slaves.

Their marriages are celebrated without any pomp or noise. The bride, as far as I was informed, is always consulted by her parents; but a refusal on her part is unknown. The poorer class of people make up matters much in the same way; that is, after having got the consent of one another, they ask their father and mother. The dowry given by a man of good condition, with regard to riches, may be said to consist of young female slaves, carved and mounted calabashes or gourds, filled with millet, dourra and rice, cloths for the loins, bracelets, and the equipage of her toilet, and one or two large wooden mortars for beating corn, \&c. and stones for grinding, \&c.; even these are carried in procession on the heads of her female slaves, when she first goes to her husband's house.

It is said that, in the event of the husband sleeping or having connexion with any of the female slaves given as dower to the wife, he must give her in lieu a virgin slave of equal value the next day. This never causes any dispute between the parties.

Their mode of burial I have never seen ; but I understand they always bury their dead behind the house which the deceased occupied while living. The following day all the friends and relations of the deceased visit the head of the family, and sit a while with him or her. If the husband dies, the widow returns to the house of her parents, with the property she brought with her.

The domestic slaves are generally well treated. The males who have arrived at the age of eighteen or nineteen are given a wife, and sent to live at their villages and farms in the country, where they build a hut, and until the harvest are fed by their 
owners. When the time for cultivating the ground and sowing the seed comes on, the owner points out what he requires, and what is to be sown on it. The slave is then allowed to enclose a part for himself and family. The hours of labour, for his master, are from daylight till mid-day; the remainder of the day is employed on his own, or in any other way he may think proper. At the time of harvest, when they cut and tie up the grain, each slave gets a bundle of the different sorts of grain, about a bushel of our measure, for himself. The grain on his own ground is entirely left for his own use, and he may dispose of it as he thinks proper. At the vacant seasons of the year he must attend to the calls of his master, whether to accompany him on a journey, or go to war, if so ordered.

The children of a slave are also slaves, and when able are usually sent out to attend the goats and sheep, and, at a more advanced age, the bullocks and larger cattle; they are soon afterwards taken home to the master's house, to look after his horse or his domestic concerns, as long as they remain single. 'The domestic slaves are fed the same as the rest of the family, with whom they appear to be on an equality of footing.

'The children of slaves, whether dwelling in the house or on the farm, are never sold, unless their behaviour is such that, after repeated punishment, they continue unmanageable, so that the master is compelled to part with them. The slaves that are sold are those taken from the enemy, or newly purchased, who, on trial, do not suit the purchaser. When a male or female slave dies unmarried, his property goes to the owner. 'The children of the slaves are sometimes educated with those of the owner, but this is not generally the case.

The male and female children of the better sort of the Fellatas are all taught to read and write Arabic, but are instructed separately. The male children of the great are generally sent to another 
town, at some distance from that where their parents reside, to receive their education; in which case they usually reside in the house of a friend, and a malem or man of learning attends them. Those of the middle and lower classes generally send their children to the schools, which they attend for an hour at day-break, and another at sunset, reading their Arabic lessons aloud and simultaneously. They are required to get their lessons by heart before the writing is washed off the board on which it is written. The ink thus diluted is drank by the scholar's, when their master writes a new lesson on the board.

The government of the Fellatas in Soudan is in its infancy; but, as it now exists, and is likely to continue, is a perfect despotism. It was left by will to Mahomed Bello, who was the eldest of Sheik Othman's sons, and is meant to descend to his eldest son at his death. The governors of the different provinces are appointed during pleasure, as, in the event of any improper conduct, they are displaced; and all their property, at their death or removal, falls to the sultan. The appointment to a vacancy is then sold to the highest bidder, who is generally a near relation, provided his property is sufficient to bid up to the mark. All the inferior offices in the towns of the provinces are sold in like manner by the governors, who also succeed to the property of those petty officers at their death or removal.

Of their revenues I can say very little. I only know that in the province of Kano they have no regular system of taxation. I great deal of marketable property is claimed by the governor, such as two-thirds of the produce of all the date and other fruit trees, the proprietor being allowed only the remaining third. A small duty is also levied on every article sold in the market; or, in lieu thereof, a certain rent is paid for the stall or shed: a duty is also fixed on every tobe that is dyed blue and sold. On grain there is no duty. Kano produces the greatest revenue which the sultar 
receives, and is paid monthly in horses, cowries, and clotl. Adamawa pays yearly in slaves; Jackoba, in slaves and lead ore; Zegzeg, in slaves and cowries ; Zamfra, the sane ; Hadiga and Katagum, and Zaonima, in horses, bullocks, and slaves ; Kashna, in slaves, cowries, and cloth ; Ader or Tadela, in bullocks, sheep, camels, and a coarse kind of cloth of cotton, like what is called by us a counterpane. Every town, on being visited by the governor or other public functionaries, must contribute to the support of these officers, and bear the expense of travelling, and feed all his servants and his cattle.

Their agriculture is simple enough. They begin clearing the ground of weeds, and burning them after the first fall of rain, which in Houssa is in the month of May; and when a person wishes to enclose a piece of ground for his own use, he first gets permission from the governor. He then sets his slaves, if he has any, to cut down the smaller trees and brushwood, leaving the micadonia or butter trees, if there be any, standing on the ground: the wood, brushwood, and weeds are then gathered together in heaps and burnt. After the first rains have fallen, the male and female slaves go to work, each male having a hoe with a long handle, and each female a basket, dish, or gourd, filled with the grain intended to be sown : the male goes on in a straight line crossing the field, striking as it were with his hoe on each side, and raising a little earth each blow in the line about two or three feet, or broad enough for a man to walk; the females follow with their baskets of grain, dropping the seeds into the holes made by the hoe, which they then cover over with earth, and give it a slight pressure with the foot. When the dourra or other grain has risen above the ground three or four inches, the weeds are hoed off, and the earth loosened around the stalks ; when the dourra has got to the height of three or four feet, they hoe around it a second time, leaving the weeds in the middle of the rows. This is cleared away, when small millet or calavanees 
are to be sown between the rows of doura, which is frequently the case. The third operation is to draw the weeds and earth towards the roots of the doura a little before it ripens. When ripe, the slaves go into the field or plantation, pull it up by the roots, and lay it in rows between each row of millet which is left to ripen : it lies in this state four or five days, when they cut the heads off, tie them up in bundles, and carry it home; where, after lying upon sheds made of the branches of trees for a few days to dry, what is not wanted for use is stowed away in their granary. As the sceds of the doura begin to ripen, it must be constantly watched by the slaves, who are perched on trees, or on raised platforms, with dried gourds, which they shake to make a noise, at the same time shouting and hallooing to frighten away the flocks of small birds which come to devour the grain, and which at this season fly in myriads, making a whirring noise with their wings when they rise. The doura is very subject to blight, caused by a kind of winged insect, of a black colour, something like the bugs on a camel; its smell is most offensive, and if killed by the fingers, the stench can hardly be borne, and is not easily washed off. The millet and calavances remain a month on the ground after the doura.

'I'he stalks of the doura grow to the height of nine and ten feet; the thunder storms, accompanied with rain and wind, often bend these stalks when near ripe, so that the roots are raised above ground, and the plant dies if the slaves the next day are not sent in to hoe the earth up to the roots of such as are broken down. 'The stalks of this grain are frequently used for fences and the rafters of their houses. Sometimes they tie the bean and millet straw into bundles, and carry them home for their camels. Their granaries are made in the form of a large urn or pitcher, raised from the ground about three feet by stones. They are made of clay and chopped straw, and are raised to the height of eleven or 
twelve feet. The thickness of the sides is not above four inches, though in any part it will bear a man's weight: the diameter in the widest part may be from seven to eight feet, at the top about three or four feet, and is overlapped at the mouth like a widemouthed earthen jar. When the grain is put in, a conical cap of thatch is put over to keep out birds, insects, wet and moisture. The doura and millet will keep well in these jars for two or three years ; after that period it perishes, and is destroyed by worms and insects. The jar itself will last seven or eight years, if taken care of, by matting round the lower part with straw during the rainy season; if not, two or three years is the period it will stand unimpaired.

'The time of putting the sweet potatoes in the ground is at the commencement of the rains, the ground being first well cleared of weeds, well hoed into furrows, the clods all broken, and the soil a good strong clay or mould. The branches or stems, in slips, are then planted by the dibble, and are two months before they have potatoes at the roots.

The gaza, though differing in taste, shape, name, and size, is not unlike a small quince : it is more watery than a gourd, of a reddish white inside, and by no means a pleasant taste; its stem is as thick as that of a gourd, with large rough leaves like those of a gourd. It is planted like the sweet potatoes, and is perpetuated in the same manner, by joints, and sown in furrows, at the same time, in a good soil of clay or mould.

Wheat, of which they raise enough to supply all who make use of it in this country, is sown after the rains, when the cold weather has set in. It is always met with by the side of a small lake or river, where they are able to water it by irrigation every day. It is ripe in three months after it is put into the ground: the grain is small. It is not much relished by the Arabs, who say that it injures the 
spleen, in whatever shape it may be eaten. The bread made of it is black and coarse ; but that may arise from the imperfect manner in which it is ground and cleaned. Barley they also have; but this grain is only used in very small quantity. The rice is sown in long beds ; and they have it in great abundance from the Surano, near Magaria: the rice of Soccatoo is considered the best in Houssa. Melons, pappa apples, the great . . . . . a few fig and pomegranate trees are grown in gardens. They have not been able to make the date tree grow at Soccatoo; whenever it gets a little above ground it rots and dies.

They have a great many wild fruit trees, the principal of which is the butter tree. Onions are brought forth at the side of the rivers or lakes, and the place on which they are growing is watered afternoon and morning, the water being drawn by a bucket and a rope fixed to a long pole, over an upright post which serves as a pivot; the water being poured into hollowed trees, conducts it to the entrance of the little squares where the onions are growing. The onions are large and good, much like the Portuguese onion. The leaves of the kuka tree, or adansonia, are carefully gathered after the rains, dried, and used in all their soups and gravies, giving to them a slimy gelatinous consistence. The sauce, or cake which makes a sauce, from the beans of the nitta tree, is in great request. The beans, when taken out of the shell, are then broken in a wooden mortar, and put into a pot with water, and kept on a good fire from sunrise to sunset, when the pot is taken off: they are allowed to stand in it until they begin to ferment and smell. They are then taken to the river, pond, or well, where they are washed thoroughly with clean water: when they are considered as perfectly clean, they are spread on mats in the sun, and carefully covered up at night. When a second fermentation takes place, or they begin to smell, they are taken and bruised 
fine in their mortars, until it becomes like paste. It is then made into small circular cakes, which are dried in the sun before they are put by for use. This, when prepared, looks like chocolate. To me it had always a very disagreeable smell; but the taste was rather pleasant than otherwise when put on roast meat or fowls. Of this the people are very fond, and go so far as to eat it alone, and without being cooked.

When they wish to plant indigo, the place chosen is one of a good strong clay or mould, and in a situation where there is moisture through the heat of the summer. After enclosing the ground, they clear it entirely of weeds, and burn them. 'I'he ground is well worked up by the hoe (they have no spade or pickaxe), and laid out in furrows, with a flat top, about a foot high, two broad, and six or seven inches between each furrow. The indigo seeds are then planted by the dibble, and just as the rains have begun: they cut it every year during the rainy season. A plantation will last four or five years without renewing the seeds. They crop it about three or four inches above the ground. 'The leaves are then stripped from the stems, and laid in a heap, exposed to the rains and weather for a month, until they ferment, when they are beaten in wooden troughs of a round form, and about two feet deep, and two feet in diameter; here they remain until dry, and are then considered as fit for use. One of these troughs of indigo, in the spring, costs three hundred cowries; in the summer, the price rises to six or seven hundred.

The cotton is here planted in low situations, where the ground is partially covered with water during the rains, or else in a good clay that has moisture in it through the dry season. The ground, or plantation, is generally only surrounded by thorny branches stuck in the ground as a fence, then hoed well, and the clods, if any remain, broken. $A$ hole is made with the hoe, and the seed is 
put in and lightly covered. If the season be abundant in rain, the cotton is plenty; if not, the crop is bad. The time of pulling is in the months of December and January. When worked, it is done by the women, clearing it of the seeds by two small iron pins, between which the cotton passes over a flat stone lying on the ground; the seeds are thrown behind them, the cotton before. The seeds they give to bullocks and camels, and are considered as very fattening. The cotton being prepared, is put on a distaff, which is short, light, neat, and small, great pains being taken in shaping and ornamenting it. The females who spin it have generally small lookingglasses in their baskets of cotton, with which they often survey their teeth and eyes. A piece of chalk, or pipe-clay, is in constant use, to rub the spinning thumb and finger. The occupation of spinning is generally assigned to married women, or some old female slave that is a favourite: weaving and sowing is left to the men. They have three different kinds of hoes: one with a handle of about five feet in length, and a small head stuck into the end of the staff; this is used in sowing the grain: one with a handle of about three feet in length, with a small iron head stuck into the end of the staff: the third, called gilma, has a short bent handle, with a large head, and is used in all the heavy work instead of a spade.

Their manufactures are confined to a very few articles, the principal of which is the dying of tanned goat skins red and yellow. 'The red skins are dyed with the leaves of a red millet, which is pounded in water mixed with natron; when thick enough, the skin is put on the stretch, and the dye rubbed in. The yellow is witl the root of a tree called raurya, which is also pounded in water mixed with natron, and laid on the skin in the same manner as the red. 'The latter are considered as superior to all the other skins dyed of the same colour in any part of Houssa. A number both of the red and yellow skins are carried to Kano and Kashna almost 
monthly, where they are made into cushions, bags, boots, and shoes, \&c.

The next article is the white cotton cloth of the country, of which they make a considerable quantity, both for the home consumption and for exportation to Kano and Nyffé: what they export is principally made into tobes and large shirts before it leaves Soccatoo. 'They have also a cloth called naroo, which is something like our counterpanes; a few checked and red striped cloths, used as tobes, and some as wrappers or zinnies for the women. The weavers of the latter are mostly natives of Nyffé, as are also all their blacksmiths. 'They have shoe, boot, saddle, and bridlemakers. Another article of export is the civet; the animals that produceit are kept in wooden cages, and fed on pounded fish and corn. A few slaves are also sold out of the province to the merchants of Kano, Kashna, Ghadamis, and Tripoli. A young male slave, from thirteen to twenty years of age, will bring from 10,000 to 20,000 cowries; a female slave, if very handsome, from 40,000 to 50,000 ; the common price is about 30,000 for a virgin about fourteen or fifteen. The articles brought to Soccatoo for sale by the Arabs are the same as what are brought to other parts of Houssa, and are mentioned in another place. Salt is brought by the Tuaricks from Billma, and also by the Tauricks of the west. The salt from the latter quarter is much better, being more pure, and in large pieces like ice. Ostriches alive and ostrich skins are brought by these people, but little is given for a skin, only from 4000 to 5000 cowries for the finest. They also bring horses which fetch a good price here; dates from Billma, and a small quantity of goods which they buy from the Arabs at Aghadiz. The articles they could export in considerable quantities, if there were buyers, would be elephants' teeth, bullocks' hides, which, when tanned, only cost five hundred cowries, equal to sixpence of our money. Goat skins, and the skins of antelopes, and 
other wild animals, might be procured in abundance, but, of course, would rise much in price if there was a great demand. Gum-arabic might also be procured in abundance. What they would take from us in exchange would be coarse scarlet cloths, which in all parts of the interior bring a good price, say 10,000 cowries a yard; coarse yellow and green cloth; red tape; unwrought silk, of glowing colours ; sewing needles, of the commonest kind; lookingglasses, no matter however small, at a penny or twopence each in England; earthenware with figures, plain ware would not pay; the coarsest kind of red camlet scarfs; jugs and hardware of the most common description, but stout; foolscap paper of the coarsest kind, if it did not let the ink through: beads, I think, are sold as cheap here by the Arabs as they are in England; sheets of tin; tin pots and cups; brass gilt rings for the fingers, arms, and ankles; as also ear-rings ; copper and brass pots, the more figures the better ; paper and wooden snuff-boxes of the commonest sort.

These Africans keep up the appearance of religion. They pray five times a day. They seldom take the trouble to wash before prayers, except in the morning; but they go through the motions of washing, clapping their hands on the ground as if in water, and muttering a prayer. This done, as if they had washed, they untie their breeches and let them fall off; then, facing the east, let the sleeves of their larger shirt, or tobe, fall over their hands, and assuming at the same time a grave countenance, begin by calling out, in an audible voice, "Allahu Akber!" \&c. kneeling down and touching the ground with the forehead. When they have finished repeating this prayer, they sit down, leaning over on the left thigh and leg, and count or pass the beads through their fingers. All their prayers and religious expressions are in Arabic; and I may say without exaggeration, taking Negroes and Fellatas together, that not one in a thousand know what they 
are saying. All they know of their religion is to repeat their prayers by rote in Arabic, first from sunrise to sunset in the Rhamadan, and a firm belief that the goods and chattels, wives and children of all people differing with them in faith, belong to them ; and that it is quite lawful in any way to abuse, rob, or kill an unbeliever. Of the Fellatas, I should suppose about one in ten are able to read and write. They believe, they say, in predestination; but it is all a farce; they show not the least of such belief in any of their actions.

'They believe, however, in divination by the book, in dreams, and in good and bad omens.

Wednesday, Nov. 29th.-This morning the Gadado sent to inform me that in the course of two days the sultan was going a short distance to the south of Soccatoo, to found a new town, and asked me to accompany him. At noon a fire broke out in the west quarter of the town, which consumed nearly 200 houses, and a great quantity of grain. At 3 P. M. another fire broke out in the adjoining house to that in which I was living. I had my baggage put out in the open square, in my enclosure, and placed a servant over it as sentry, and went with my two other servants to assist the wives and concubines of my friend Malam Moodie, who was out of town. 'They were busy in removing the household goods into the street. This I stopped, and had them put into my square; as I saw that the fire was nearly put down by the removal of the roofs of the huts in the adjoining house, and by applying wet mats. Thieves were in abundance, and a great quantity of articles were stolen belonging to the people whose house was on fire. There was fortunately little wind, or several other houses would have been burnt. As it was, the light and burning thatch was carried to a great distance. My servant, Mohamed Allah Sirkie, got great praise from the Gadado for his activity in putting a stop to the 
flames: after all was over, the principal wife of Malam Moodie sent her compliments and thanks to me for taking care of her husband's house and property. There have been three fires in the town in the course of the day; they say they were done by the agents of the rebels, who tie a burning cotton thread to the tail of a large species of buzzard, with yellow head and reddish-yellow tail, and blue body, common in this country, which flies to the thatch of the house when set adrift.

Friday, Dec. 1st.-At 4 P. M. left Soccatoo by the southern gate, with a camel carrying my tent and bed, with a small quantity of provisions. After leaving the gate, the road was over what had been plantations of millet, doura, and beans; the soil a stiff red clay, covered with a thin layer of sand, with blocks of clay ironstone, which is often mixed with white pebbles; sometimes it would cover a space of a quarter of a mile, like a crust, of about from two feet to two and a half feet in thickness; the face of the country almost bare of trees, but studded with villages; the herds of horned cattle were to be seen in great numbers every where, returning to their night's quarters, feeding as they went along. The country hilly, with very steep and slippery ravines in many places.

At 8 P. M. halted at the camp of the sultan, which was in a valley of about three miles wide, and close to the bed of a small stream passing the east of Soccatoo, which was distant about two miles and a half to the north-east. After my tent was pitched, the Gadado sent me a sheep, and I had my share of a bullock that was killed. There were very few people with the sultan, and the Gadado had only three servants with him.

Saturday, 2d.-Morning clear and cool at day-light. Rode out with the sultan and Gadado to mark out the site of the new town. I took my gun with me, intending to shoot: we rode to the 
eastward about two miles, and halted within a short distance of the river, on the side of a low hill, sloping to the river by a gradual and easy descent. This was the place fixed on for the new town, which I left them to settle, and went to shoot; but was never more unsuccessful. I saw several antelopes and some bustards, but could not get within shot. At noon I returned to the camp. The reason of founding this town is, that the woods on the banks of the river are the resort and hiding-place of the rebels, who come and plunder the herds, and set fire to the villages before they can have information; and in Soccatoo the rebels are hid with their prey in the woods. In the evening, as it was also last night, the cryer went round the camp, calling every one to look well after their horses, camels, and baggage; to pretend to sleep, but not to sleep, as the place was full of robbers; and that every one seen outside the camp after this notice, whether Fellata or not, was to be secured. I set off three rockets at the request of the sultan; for though I have shown them several times, they are still afraid to try them, and the wonder and alarm is still as strong in their favour as ever.

At 11 P. M. a courier arrived from Magaria, bringing information that the rebels of Goobur had encamped a little to the eastward of that place in great force. The order to march was given, and the camp was cleared in a few minutes. I first saw my camel and baggage well forward on the road to Soccatoo. Before I took the road for Magaria, which was across the country, the alarm was spread from village to village, by a cry not unlike the Indian warwhoop, with a clear shrill voice; and bands of horse and foot were pressing forward every where at day-break. We met large parties of women, children, old men, bullocks, sheep, and asses, all flying towards Soccatoo.

At 10 A. M. I arrived at Magaria, where all was now quiet; 
and put up at the house of my friend the Gadado, who had gone to rest, having arrived an hour before me. Maalem Moodie, his brother, told me that all the rebel army turned out to be only a few robbers come to steal bullocks, one of which, on their not being able to drive them away, they had killed, carried away its flesh, and fled. On my asking one of his female slaves, who had the charge of his house at Magaria, why they had been so much frightened by only a few thieves, she replied, "What could we do? only a parcel of women to be seen : there were two or three fellows within hearing of the noises, but they were good for nothing; they were just as much afraid as we were. All night (pointing to the highest point of ground in the town, which is unoccupied, and kept for a market-place) did we stand there with what things we could carry on our heads, our mouths open, no one thought of eating or sitting down until the men came from Soccatoo and the camp. 'This world," continued she, "is nothing without the men after all. If three of the thieves had only come, they might have taken the town and all that was in it, for the gates were all open, and we had not sense to shut them."-After breakfast and a good sleep, I waited on the Gadado, and told him that, as all was happily quiet, I should return to Soccatoo at day-break to-morrow, as I had neither bed nor baggage with me. He thanked me very much for coming to their assistance, and said he should also return to the capital in the course of the next day, and the sultan intended returning to the camp.

Sunday, 3d.-At day-break mounted and rode to Soccatoo, accompanied by my freedman, Mohamed Allah Sirkie, who accompanies me on all enterprises of danger. At noon arrived at Soccatoo, and the Gadado arrived at midnight.

Wednesday, 6th.- The eunuchs of the sultan came to-day, wishing me to go to the sultan's house to wind up the time-piece. G G 2 
Though I taught a man how it should be done, and to do it every eight days, they have always neglected to do it: only for such an excellent time-piece, the present of his majesty, and my having brought it so far without injury, I would not have put a finger to it again ; but the Gadado coming, and asking me to go with him, I showed another how to wind it up.

Saturday, 9th.-News from Magaria this day arrived, that the people of Goobur had formed a camp outside the walls of their capital, and there elected a new sultan or chief, in the room of the one killed at our attack on Coonia; that he must go on some expedition against their enemies before he returns to his house, such being their custom : but at what part he is going against they do not as yet know. The custom of the Gooburites is at first that, when they elect a chief, which they do outside the walls of the capital, where they sacrifice a bullock, a sheep, and a goat, under a tree, they must go on some expedition against their enemies before they return to their house.

Tuesday, 12th.-Part of the tribe of Killgris, Tuaricks, or Berbers, who inhabit that part of the desert between 'Timbuctoo and Tuat, and to the north of Tadela, and Ader, come on their annual summer or dry season visit to Soccatoo; also part of the tribe of Etassan, from that part called Anbur, which lies to the north of Kashna and Zinder in Bornou. 'The latter brought the sultan a present of a fine Tuarick horse from their sultan, who has not come this year to pay his yearly respects to Bello, as is the custom. The Tuaricks, or Berbers, inhabiting the south part of the desert, consist of the tribes of Etassan, Killgris, Killaway, and Timsgeda. Ajudiz is the capital, and they jointly depose their sultan and elect another when they think fit, which is generally once every two or three years. 'They do not kill the old one; he only retires from his office, and remains as a common man. 
They yearly, after the grain has been cut and got in, arrive in Houssa with salt, which they visit in the latter end of harvest, or in the months of October or November, to exchange for grain, blue tobes or large shirts, mugabs or blue turban dresses for their women, and swords ; they also lay in a sufficient quantity of millet and doura to last them through the season, until they return to their own country, as they neither sow nor reap. During the whole of the dry season they remain in Houssa, principally in the provinces of Kano, Kashna, Zamfra, and Soccatoo. The latter mostly Killgris; and Kashna and Kano are the principal resort of the Etassan and Killaway: they do not live, except a few, in houses in the town; but build temporary huts in the woods, not far distant from them, where they have their wives, their bullocks, horses, and camels, the men only visiting the town: in this way they live until the month in which the rains commence, when they retire north to the desert. They are a fine manly looking race of men, but extremely dirty in their persons, not even washing before prayers, but going through the form with sand, as if washing. The poorest amongst them are armed with a sword and spear, which are their constant companions.

Wednesday, 13th.- The sultan sent me a present of a sheep and four Guinea fowls and some rice, from the Sanson, apologizing. for his long absence in the camp, as the 'Tuaricks were very unsettled, and they had not as yet determined what party to side with.

Thursday, 14th.-I to-day employed Hadji Omar and Malam Mohamed, the latter to give me a route, noting the northing and southing of the road, between Massina, the country in which he was born, to Soccatoo; the other, who has just returned from Mecca, to give me an account between this and Sennar, with a description of the countries, towns, and rivers: his route is from Kano 
to Adamowa, Bagermie, Rumza, Kaffins, Darfoor, and Kordofan: he says the Bahr-el-Abiad is only about four feet deep in the summer, as is also the Shari above Logan, before it is joined by the river Asha, which comes from the south-east, through Bagermie, and falls into the Shari above Logan. This is the only river not fordable in the summer between the Quorra and the Bahr-el Azrek.

Monday, 18th.- I was not a little surprised to-day with the arrival of a messenger from Kano, who had left, he said, my servants and baggage at the border town, or, as they call it, the Sanson, of 'Lamfra, with Hadji Salah, my agent; all of which he said had been sent for by the sultan's order: he also said that Pascoe had been taken and brought back by Richard, after his having got as far as Roma, in Zegzeg, and that he had twice run away since, and had been taken, committing a fresh robbery each time; the last time was at the Sanson The only construction I put on this strange proceeding was, that the sultan had done it, thinking that my things would be safer with me than at Kano; and, as my health was not very good, the account of Pascoe's repeated robberies would make me worse; and he, I thought, had judged that it would be time enough to tell me when all my things had arrived.

Tuesday, 19th.-I was visited by Sidi Sheik, who is one of the sultan's Arab secretaries and confidential friends, who, after a little conversation on the affairs of other people, asked me if I was not glad my things were coming, and my servants. I said it would put me to an expense I could ill afford, and I thought it a very strange proceeding of the sultan.

Wednesday, 20th.-I was very ill all day, and in the evening I had a visit from Mohamed Ben Haja Gumso and Sidi Sheik, who said they had been sent to me by the sultan, to tell me not to consider it strange that he had sent for my servants and baggage; and to tell me, that there were three roads by which I could 
return, one of which I must choose; also to speak the truth, had I come as a messenger from the king of England to Bello, or only to seek out a road? that one of the paths was through Yourriba, the way I had come; the other by 'Timbuctoo; and another' by way of Aghadez, Tuat, and Morzuk. I said that, after such a message, and such unwarranted proceeding on the part of the sultan, I could have no further communication with them; that they might act as they thought fit, all was the same to me. They went off, saying I was a very difficult man; had I nothing to say to the sultan? I said that my business with the sultan was now finished, and I would have no more to say.

Thursday, 21st.- In the morning I sent to the sultan to take possession of my baggage, as it now appeared from Sidi Sheik, who early visited me, that they considered I was conveying guns and warlike stores to the sheik of Bornou. He sent to say that no one should touch my baggage; he only wanted to see the letter of Lord Bathurst to the sheik. I answered, they must take it if they pleased, but that I would not give it. At noon the Gadado arrived, and a short while after Hadji Hat Salah; the latter called on me as he went to his house. He declared that he knew not on what business they had sent for him; that he did not fear them, he had done nothing amiss. As there were too many persons around, I did not ask him any further questions, and instantly went to the Gadado, whom I found alone, sitting by a warm fire. After the usual compliments were over, I asked him for what reason the sultan had sent for my baggage. He said of that he had not the least knowledge, until my servants and baggage had arrived at Magaria; but the sultan had told him, since his return, that all he wanted was to see the letter to the sheik of Bornou. I told him that to give up the letter was more than my head was worth. He said they did not want to open the letter, they only wanted to see 
the direction, and if it was really from Lord Bathurst. I told him of the strange conversation of Ben Gumso and Sidi sheik. He said, certainly such was not the message of the sultan, but an addition of their own; the sultan never sent to ask if I was really a messenger of the king of England.

At 3 P. M. my servant Richard arrived with my baggage and Pascoe. Richard had been very ill on the road, but had received every attention from the people in the different towns in which he had halted, and also from the messenger which the sultan of Kano had sent to accompany him, who had also given him five bullocks, and four men to accompany him and carry the baggage, and a camel which Hadji Salah had bought for me, for 60,000 cowries. 'The price of the bullocks was 12,000 each, and the pay of the men 4,000 cowries each. Richard's account of Pascoe was as follows:-The second day after Pascoe's first desertion, he, though very ill, secured all my baggage and goods in a secure room in the house, and went and gave Hadji Salah the key, declaring he must be answerable to me if any thing was lost, as he was going to bring Pascoe back. Hadji Salah advised him much not to go ; but Richard, with the Arab servant whom I had left sick, and who was now recovered, mounting the two horses, took the road to Quorra, the capital of Zegzeg. When they arrived at the town of Aushur, in Zegzeg, they were informed by a person who had just arrived that Pascoe had been firing a pistol in the market-place in the town of Roma, a day's journey ahead. They arrived at Roma, where the people informed them that Pascoe had been there, but had gone away. Richard stopped there that night, as the horses were unable to proceed. A short time after halting, some people came and informed him that he (Pascoe) was stopping in a woman's house near the market-place. Richard immediately sent people to the gates of the town to stop him, if he attempted to depart. 
Richard was too ill to go to the house, but sent Abdulfitha, the Arab, and some other people to secure him, and bring him to the house, which they did, and he promised faithfully to behave well for the future ; and Richard had him put inside of the hut, he and the Arab sleeping at the door. Next day they departed with their prisoner for Kano; but when within half a day's journey of Kano, where they halted for the night, during the time Richard was asleep, Pascoe slipped out of the hut, taking with him all the arms and money Richard had. He immediately mounted, and as he had now neither money nor arms, he started for Kano, where he arrived early in the morning, and told Hadji Salah to send instantly after him, which he did, and Pascoe was brought back in two days after, and put in irons in a house in Richard's charge until the arrival of the governor of Kano, when Richard set him at large, after his taking an oath before the governor that he would not run away, or misbehave, until he joined me: this was the day before Richard's departure from Kano. After leaving Kano, Richard was nearly dead with fatigue, weakness, and watching; but the fourth day he got better. Ten days after Richard arrived at the Sanson, or town, called Fofin Birnee, bordering on Goobur and the territory of the rebels of Zamfra. Here he was waiting for an escort to take him through the part of the road infested by the rebels of Goobur and Zamfra, when Pascoe, the third night after their arrival at the Sanson, took an opportunity, when Richard was asleep, of breaking open one of my trunks and a gun-box, taking a doublebarrelled gun, five gilt chains, two dozen and a half pairs of scissors, all my money, a brace of pistols, seven hundred needles, one dozen of penknives, and a large quantity of beads. Richard immediately gave the alarm, and the people of the town were sent after him directly: they returned with him the next night. He having taken the road towards Goobur, and the hyænas being numerous, and 
following him, he got up into a tree, and fired his newly-acquired gun at them, the report of which brought those in search of him to the place, when they brought him back, and pinioned him to the ground, and abused him very much. When Richard asked what the Fellatas were saying, he said they were cursing Richard for having him pinioned to the ground, but Richard would not have him let loose. On his arrival here, the Gadado asked me to forgive him: I told him that was impossible. They allow him to go at large, and he stops in the house of the Gadado's master of the camels. When I saw him, he appeared as if nothing had been the matter. I forbad my servants holding any communication with him.

Friday, 22d.-In the morning the Gadado sent for Allah Sirkie to tell me the sultan wished to see Richard my servant, as he had never seen another Christian besides myself; and he also wished to see me, and I was to bring the sheik's letter, which he by no means wished to take from me, or to open; he only wished to see how we addressed him, and if it was in a tin case like his. I went after the mid-day prayers with the Gadado, taking with me my servant Richard, whom they all called Insurah Coramina, or the little Christian, and Allah Sirkie, to the sultan's, where we found him sitting in an inner room, better dressed than usual, and Mohamed Ben Hadji Gumso and Sidi Sheik sitting on his left: the Gadado sat down on his right, I with my servants in front. After his asking Richard and I how we were, and a few other questions, he then said he had sent Ben Hadji Gumso and Sidi Sheik to me, to inform me that he had sent for my people and baggage. Before he had not informed me, but now he would tell me how matters stood. The king of England had sent me to him, but I wished to go to the Sheik of Bornou: that between him and the sheik there was war; and therefore, though I had come from the king of England, 
he would not allow me to go: that there were three roads, out of which I must choose one; and he would send people with me; one road was the way I had come, the second by way of Timbuctoo, and the third by way of Aghadiz and Fezzan. I answered, that by the way I had come he could not send me, nor was it safe I should attempt it, as all Yourriba and the other countries at war with the Fellatas were now well acquainted with my having come here as a messenger, with presents from the king of England to him, for the purpose of putting a stop to the slave trade. That the way by 'Timbuctoo was almost impassable, for the Fellatas from FootaTorra and Foota-Bonda, \&c. who had arrived here a short while ago, had with the greatest difficulty been allowed to come here with nothing but a staff and a shirt, and had been twelve months on the road, owing to the war; and that, were I to go, all the country would hear of me, and his enemies would have me and all my baggage before I had been two months on the road. That the road by Aghadiz would require a number of camels, more than I could afford to buy at present, also a great deal of provisions, waterskins, \&c. as there was no place for seven days' journey that supplied either wood or water: that the Tuaricks were a people without either law or government; and if they did allow me to go, I should have to pay very dear for their permission, at least two camelloads of blue tobes and turbans; but if he would allow me to go by the way of Baghermi, Darfoor, and Egypt, I would go at all risks. He replied that was just going by way of Bornou, as I must pass through from Adamawa to Logan. "With truth," said old Ben Gusmo with great earnestness to Sidi Sheik, and loud enough for the sultan to hear, "do you hear how that man talks before the prince of the faithful ?" He, the sultan, then asked to see the sheik's letter; I showed it to him, as also the Arabic list of medicines which I had brought as far as Badagry for the sheik, but 
had sent them back. He asked me to open the sheik's letter, after he had read the list of medicines. I said, it was more than my head was worth to do such a thing; that I had come to him with a letter and presents from the king of England, on the faith of his own letter the preceding year, and I hoped he would not break his promises and his word for the sake of seeing the contents of that letter which he had now lying beside him. He then made a motion with his hand for me to go, and I accordingly rose, made my bow, and went out: I saw Pascoe at the door, ready to have his audience, the Gadado accompanying me as far as the door. Instead of going to my house, I went to see Hadji Salah, who certainly was but poorly lodged by the Fellatas. I asked him, as there was none present but the son of the former sultan of Fezzan, and whom he had brought from Kano with him, what had brought him to Soccatoo? He said, they had not yet told him, but he did not care for them. The house, as soon as it was known that I was there, was soon filled with Fellatas, and I left him.

Saturday, 23d.-Hadji Salah to-day saw the sultan, and I was informed by the master of my house that he was to return to Kano in four days after this. In the evening, Hadji Salah, having asked the Gadado's permission to pay me a visit, came about eight P. M.: he was not watched, that I could see. He informed me that he had seen the sultan to-day, who had desired him to tell the truth, whether I had given him the sheik's present, or any thing for the sheik before I left Kano. He said he certainly never received any thing from me for the sheik, neither letter, nor goods, nor any thing else. After answering to this effect, as also the two friends that had come with him, the sultan told him it was well; he would allow him to return to his family in four days. He said, with respect to me, he would advise me, as a friend and a man of peace, to give up to them the present I had for the sheik, and return home by 
the way of Aghadiz, which they had proposed to me; that there was not a Fellata, from the sultan to the meanest man amongst them, that could bear the sheik of Bornou, or any one who had ever been friends with him; that, thank God! I had put nothing into his hands for the sheik, or he would have lost his head; that he would (most earnestly repeating it again) advise me to give up the sheik's present to them, as I could not keep it. I observed that it was the same thing as forcing the letter from me; it would be the last injury they could do me; that they had broken all faith with me; I could have no more to say to them: after their cheating or robbing me of the letter, they might take what they pleased. I was only one man, I could not fight against a nation : they could not, even by taking away my life, do worse with me than they had done.

Sunday, 24th.-I saw the Gadacio this morning, who complained that he had got a bad cold: I recommended him to take a dose of senna. He said he had to ride out of town a short distance, to meet Mohamed Ben Abdullahir, Bello's first cousin by the father's side: he is the Fellata king or sultan of Nyffe', and is coming here to get permission to go down this year, as before he had sent only a relation or head chief to command there, which was Omar Zurmie, whom I had seen when there. He asked me to go with him to meet Abdullahir. I told him no; my affairs with them were now at an end: after the manner in which the sultan had behaved to me, it was impossible for them to put a greater affront on me than what they had done. He said that when I came here before, I had come with letteis from the Bashaw of Tripoli and the Sheik of Bornou, and that at that time they were all at peace; now they were at war, and the sultan neither held, nor allowed others to hold, any communication with the sheik or his people: that I had come then with a letter and presents from the 
king, and delivered them; that I had a letter and presents from the king of England's vizier; that when I sent the sword from Katagum to Bello, from the king of England, the Sheik of Bornou had seized the letter that came with it, and they had now done the same by him; and that, if I would give up the present, they would send it by Hadji Salah. I said there was no letter whatever came with the sword and box I had sent from Katagum. I observed to him, that the conduct of Bello was not like that of a prince of the faithful, who, in defiance of his letter requesting the king of England to send a consul out, had broken all faith between us; that they had done every evil to me they could. The Gadado pleaded the letters sent from the Sheik and the two Hadjis of Tripoli, saying that I was a spy, and that we wanted to take this country, as we had done India. He was very sorry for what the sultan had done, he said-as sore at heart as I could be : that they had sent for Hadji Salah, who had been fourteen years in this country, and all that time transacting the business of the Sheik, to tell him, if he chose to go to Bornou, to go; if he remained, he must not interfere any more for the Sheik. I said, what had I to do with the Sheik or Hadji Salah's affairs? he was my agent before, and that was the reason I had employed him a second time. I then took leave of the Gadado, after repeating to him what I had said above, two or three times, till he perfectly understood what I had said; and adding, that I never wished to see the sultan again, and I must insist on the Gadado to repeat to him what I had said; and also that I must for the future consider every part of his dominions as a prison, for he had broken his word in every thing. Notwithstanding all this, the Gadado and his brother Moodie still send me milk and food the same as usual ; there is not the least difference in their conduct. The common conversation of the town now is, that the English intend to take Houssa. 
Monday, 25th._Being Christmas-day, I gave my servant Richard one sovereign out of six I have left, as a Christmas gift; for he is well deserving, and has never once shown a want of courage or enterprise unworthy an Englishman. The Gadado early sent to know how I was, and desired my servant to tell me he had acquainted the sultan with all I had said; and he inquired if my heart was difficult as ever, which is their way of asking if I meant to talk in the same strong language. Pascoe was to-day sent to the house of Ben Hadji Gumso, from that of the Gadado's servant, with all his baggage; whether for the purpose of fishing him or making him say what they want, or to make him a slave, I do not know. He made a fair recantation of his faith to-day before an Imam and the Gadado : the latter told him, when he had done, to go and wash limself from head to foot - that yesterday he was a Kaffir, but now he was friends with the prophet. I had provisions sent as usual in the evening.

Tuesday, 26th.-Early this morning I was visited by Hadgi Salah and Malem Moodie, the Gadado's brother. They said they had been sent by the sultan, who had read the letter addressed to the Sheik, in which it was said that I had six guns for the Sheik, two boxes of balls and one box of powder, and one chest of goods as presents, and they were come to demand them. I said it was untrue; no such thing could have been put in the letter, for that the guns belonged to myself and servants, except those of the gentlemen who accompanied me, and who had died in Yourriba, and two others as presents: this falsehood they must have had from their friend Pascoe. The present I had intended to give the Sheik I had all ready prepared, and the Gadado entering, I ordered my servants to bring it forth : the Gadado, looking over the articles, said he did not want any thing of mine; whatever belonged to the Sheik they would take, for he was making a very unjust war upon 
them, and they would not allow any one to carry arms or warlike stores to him. I told the Gadado that they were acting like robbers towards me, in defiance of all good faith; that no people in the world would act the same, and they had far better have cut my head off than done such an act; but I supposed they would do that also when they had taken every thing from me. The Gadado flew off in a great passion, and the rest followed, carrying the present for the Sheik with them. Hadji Salah said he was afiaid they would cut his head off, and he was a man with a large family; he would from this time forward have no further concern with me or my affairs. A short while after this, Hadji Salah and his attendants came with a message from the sultan, to say the sultan had ordered them to tell me that he did not wish to do any thing or say any thing unpleasant to me; all he wanted was to know if I had any arms or warlike stores for the Sheik-if I had, to give them up: I told him all I had for the Sheik they had already taken. Hadji Salah wanted me to give up all my own arms: I told him I would not give one. He said, I was once, he thought, a wise man, now I acted like an unwise one, not to give up all to save my head: I told him I would not give them a charge of powder to save my head. 'They went off displeased again.

My servants and all my visitors fell off at this time. My servants said they were afraid to remain, even Allah Sirkie. This cowardice and ingratitude I did not expect from one I had found a slave, with only a leather skin about his middle, and whom I had clothed, fed, given him wages the same as my other servants from the day I bought him, and made him free. I told them they were at perfect liberty to go where they thought proper; that I could soon get others who, after the manner in which I had behaved to them, could not behave worse : they however returned in the evening, and begged I would take them back, which I did; as lies, and 
ingratitude, and petty robbery, no servant who is a native of Houssa, Fezzan, or Bornou, is free from.

Thursday, 28th._- The Gadado left to-day for Magaria: before he went, he told me he should not stay long away; that if any thing unpleasant happened to me during his absence, to send an express off to him directly. In the afternoon the sultan left for the Sansan or new town, which he is building. He sent, by Sidi Sheik, to ask me to go and show him the way to build a house and fortify it; but as I did not believe what he said, I took no notice of the message. It afterwards turned out that Sidi Sheik had a relation who had lately arrived, who was a builder, and he wanted to introduce him to the sultan.

Friday, 29th.-I applied a large blister to my side, as, from the enlargement of the spleen, it gave me great pain, having increased to such a size that $I$ was unable to eat, and had little or no rest.

Sunday, 14th January, 1827.- No news from Magaria. After sunset, a messenger with a horse for me arrived from the Gadado at Magaria, wishing me to go there.

Monday, 15th.- Started at sunrise for Magaria; but I was so ill on the road that I did not arrive there before 5 P. M. All the reports of the enemy being near proved untrue.

Tuesday, 16th. - Waited on the Gadado and sultan. The latter told me, as soon as the reports of the rebels being out were found to be true or false, I should go ; that he intended I should go by the way of Asbur, and that I should visit the country of Jacoba during the interval; that he should send a Fellata to Tripoli with me. I returned in the afternoon, and arrived at Soccatoo a little after sunset.

Wednesday, 17th.-A small gaffle of Arabs arrived to-day from Timbuctoo, one of whom had seen Major Laing, who, he said, had lost his hand in an attack which the Tuaricks had made on him 
and his servants during the night, and that his servants, a Jew and a Christian, had got severely wounded.

Saturday, 20th.-Sent Richard to Magaria with a letter to the Gadado, urging him to apply to the sultan for permission to visit Jacoba and the southern parts of Houssa, that I might be able to ascertain whether and where the Quorra fell into the sea.

Friday, 26th.-Light airs, with a slight haze; at 8 strong breezes from the E. N.E. The sultan sent to inform me that a courier had arrived from the sultan of Kano, informing him of the sheik being only a day's journey to the south of that place ; and the Sultan Bello wished to know if, after such intelligence, I wished to go to Kashna. Sidi Sheik was the bearer of the message. I, of course, said I should remain where I was at present, without making any observations, as the news might be untrue, and it was only a catch to get at my intentions.

Saturday, 27th.-Cool and clear. At day-break the Gadado arrived from Magaria. In the forenoon I visited him, when he told me he was going to Kano : he said that as soon as every thing was settled he would write for me to come; but that I had better remain where I was until the sheik had returned, who was at Sangia, on his way to Kano. It seems the sheik, before he entered the territory of Houssa, had sent to the governors of Katagum, Hadiga, Lamema, and Kano, to say he was not at war with Bello or his people, but at peace; that he had only come to take Mohamed Mungo and Mohamed Nema, two of the Fellata chiefs on the frontiers, who were constantly invading Bornou, and carrying off the inhabitants and cattle. Instead however of looking after these chiefs, he entered the province of Shena, took all the people and cattle he could lay his hands on, and was now on his march to Kano, trying to cut off the sultan, who was at Dushie, the frontier town, to assist Hadgi Katagum in case of attack; but on hearing that the 
sheik was on his march to Kano, he had returned to secure that important city.

Sunday, 28th.-Clear and cloudless sky. Took leave of the Gadado, as he goes to Kano to-morrow to take command of the forces. The whole of the Fellatas are in the greatest state of alarm, as they expect the whole of the blacks will join the sheik, as also the Tuaricks: they are now busily employed in getting their grain into Soccatoo, expecting an attack here.

Monday, 29th.-The Gadado did not leave until the afternoon. The sultan, and every one that could muster a horse, besides a number on foot, accompanied him as far as the river side, which runs to the north, on the east of Soccatoo: here they repeated the fatha, after which all those not going to accompany him returned.

Thursday, February 8th.-Having taken leave of the sultan, I put all my baggage, except one trunk and the canteen, into the Gadado's house, as well to prevent robbery as to guard against fires; which are very common in Soccatoo; taking my two camels and all my servants for Magaria. At $8 \mathrm{~A}$. M. one of my camels being sickly and weak, we travelled very slowly until 3 P. M., when I halted at a village near the road-side, where the head man gave me a hut to sleep in; and the river being about two miles distant to the north, we sent the camels out to feed, and left Richard and Allah Sirkie to pitch the tent and take care of the horses. I went down to the river side with the gun, to look at the hunting ground: I was attended by Malem Moodie, the owner of the village, on horseback, and about twenty of his slaves. $\mathrm{He}$ is the only free man in the village, which consists of about seventy men, women, and children. After descending the rocky and gravelly side of the hill over which the road lies, I came upon the flat, which spreads out about four miles to the foot of the high ground or low hills. On the north side, the river overflows all the flat during the rains; and the former 
course of the river has left several pools and beautiful lakes of water. The soil in the flat is generally a blue clay and mould to a depth of from three to four feet; in the upper parts planted with cotton and gourds, and the other parts, during the rains, with rice, which is of a very good quality. The river runs at this place in a narrow winding bed, about twelve feet deep; the banks sandy below the strata of clay and mould; and the falling of trees, and the looseness of the soil, cause it often to shift its bed through the flats or swamps in the rainy season. The acacia trees were in blossom, and the traces of elephants were numerous. I saw only three antelopes, but great numbers of guinea-fowl, which were too wild to come near, as they are so much hunted by the young Fellatas; so I returned without any thing. I was very anxious to have shot a wild boar, of which there were great numbers; but Malem Moodie was quite shocked at the thought of my wanting the skin, so that he would not, I suppose, have let me or my people have any supper if I had touched it; though he had no objection to my shooting as many as I pleased of their Kaffirs and Eblis. I returned to my hut in the village, when the Malem, at meal-time, sent me a large store-pudding, and gravy made of butter and the leaves of the adansonia, with corn for my horses.

Friday, 9th.-After day-light, left the village of Malem Moodie, having given his female slaves who brought the pudding and millet the full price in cowries, and the old Malem two gora nuts: the old man was quite pleased with the present, and accompanied me a little distance on the road, calling at two other villages on the road-side to show his guest to the people. Though they have seen me fifty times, every man and woman, for twenty miles round Soccatoo, still their curiosity is as great as ever, examining my dress, and the dress of my servant Richard; the buttons of brass they always call gold: also my English bridles, and the cloth of my trousers, 
and my coat, which is a striped printed dressing-gown, draw the attention of all the women, young and old, who beg always a piece of the same to tie round their heads: all good things, they say, we have got. They call me the big Christian, and my servant Richard the little Christian : my old name of Abdulla is seldom used, except by those who knew me when $I$ was here before, and that only to my face. At 10 A. M. arrived at Magaria. My friend Malem Moodie was not at home; but I took up my quarters at my old house; and Moodie's wife, the one that lives here (for he has four wives and sixteen concubines), sent me plenty of milk and doura. Moodie arriving, I told him I had come to remain a few days to shoot, and I wanted a man to show me the ground: he soon got me one, and I had every thing ready to start next morning.

Saturday, 10th.-A little after day-light left Magaria, and riding through between a number of plantations of cotton on the low ground, which had been covered during the rains, we came on to the rice ground, which is now covered with fine green grass, and has several small lakes and pools of water formed by the ancient beds of the river. The sides of the lakes and pools were swampy for a considerable distance, so that there was no getting within reach of the birds with small shot. They consisted of the white and gray pelican, the Muscovy duck, Egyptian goose, ducks, widgeons, and snipes; the heron, adjutant, ibis, and a small white crane were numerous. On the low flat were feeding, amongst the herds of bullocks, five or six of the large red antelopes, between the size of the common antelope and the nylghau, of a red colour, about as high as a small ass, with large thick horns, called by the Arabs the hamoria, and by the people marea. I did not look after them, as there was little cover, but rode over to the north side of the flat, where the river lies, expecting to find plenty of game and plenty of cover. On approaching through the flats, and within about a 
mile of the river, the woods were almost impenetrable, abounding in wild hogs and guinea-fowl : of the latter I shot some, but the hogs were forbidden fruits. I had no wish to kill them, except to eat, or to have their skins; and my own servants would have been the first to have held me up to abomination if I had done so, as the less these rogues know about their religion, the more they adhere to the less scrupulous points of it; the whole they know being to repeat their prayers in Arabic, not a word of which they understand; abhor a Christian, a Kaffir, and a poor harmless pig. I saw five elephants, and the traces of a great many more. They hunt them, or set watch for them in their regular paths, sitting on the branch of some high tree which overhangs the path. 'Their weapon is a harpoon, with two moveable barbs, like our whale harpoons, but a shorter shaft, which is stuck into the end of the large wooden pestle with which the women beat the husks of the rice and millet in their mortars. 'The iron head is poisoned, and night being the time, they strike on the back as the animal passes under the branch. The hunter traces him for a little distance; the wood of the harpoon drops off, and if the animal does not soon fall, the hunter returns home until next morning, when he is sure to find him dead near to where he had left him. They eat the flesh, and sometimes sell the tusks for a few cowries, or they are oftener brought to the sultan or Gadado, along with the trunk, as a proof of their victory; the tusks they always give to the Arabs. Three have been killed since I have been here: they watch only in the evening. At sunset we returned to Magaria, all very tired, and I with my old dressing-gown torn to ribands.

Monday, 12th.-I went out to hunt on the flats on foot, with a Fellata to drive in the game, my servants being all knocked up, and too tired to accompany me. After getting on the ground, I lay down amongst the long grass, and sent out the Fellata, who 
twice drove the game close to where I was lying, but on both occasions I was sound asleep, being overcome with fatigue, and I got up and returned home. As I was returning I fell in with an old sow and five pigs: I let fly at her, as she with her whole family were coming up to take a look at me. This, as I did not hit any of them, did not at all disturb her or her brood, who, by their size, might be about nine months old; she, with four of the young ones, only turned on one side, and walked slowly amongst the long grass. As I came nearer, the fifth, a young boar, came snorting up, with his tail erect, to within pistol shot; I presented the gun to him, but he seemed to care very little for me, and I did not like to kill him. After both had satisfied ourselves with looking at one another, he, sceing the whole of his relations in safety, turned round with a grunt, and strutted after them, with as little fear in his gesture as if he had been lord of the soil. The wild hogs of Africa, both in Borgo, Houssa, and Bornou, are the same in appearance, having a head much larger in proportion to their bodies than the domestic hog of Europe. In Yourriba and Nyffe' the snout is very broad and round, with two large tusks on each side, one in each jaw, both upper and lower turning up, the lower fitting also the upper and outside; the back of the neck covered with a mane of upright bristles of a snuff-brown colour, no other hair appearing on any other part, except at the tip of the tail : they are universally of the same colour, a dark mouse or lead colour: the height of a full grown boar is about three and a half or four feet, and from the tip of the snout to the root of the tail about five feet. They have also two warts on each side of the head, on a line with the nose, the largest below the ear, two inches and a half, the other about an inch lower down, upon the end of the upper tusk, which look like two horus.

Tuesday, 13th. - I did not go out until nearly mid-day, and then went to the south of the town, amongst the hills and woods, but 
again was unsuccessful. Though the traces of game of all kinds were numerous, yet I saw nothing but one flock of antelopes, which I could not get near; guinea-fowl were in plenty, but as shy as before. The hills were composed of loose clay, iron-stone rocks on the surface, and a red clay and sand for the depth of about four or five feet, then a dull whitish or rather bluish clay, containing shining particles of mica underneath. Several of the stones had rounded pebbles imbedded in them; others were, on breaking, like yellow ochre; the outer surfaces of all as if they had been burnt in the fire. This is owing to the weather I suppose, as well as the appearance of having been melted from the rains and sand beating on them, and wearing away the soft parts. The blocks of rock never exceed six feet square when loose, and when covering a flat, never above three or four feet thick over the clay soil. I forgot to mention that the greater number, when broke, present a glistening or shining appearance, like iron-ore, and that they are much heavier than pieces of sandstone of the same bulk. After tiring myself amongst the hills to no purpose, and I and my guides being very thirsty, we went across to the north, to a small lake on the flat or plain, to drink. Here I fell in with a party of Fellata girls washing their gourds, from which their people, who had a temporary bullock or cattle village close at hand, under the shade of some large adansonia (kouka trees), had just gone out on the flats with their cattle. 'I'hey gave me curdled milk and water to drink; after which I lay down by the side of the lake, and took the bridle off my horse, to let him enjoy himself also amongst the fine green grass.

Wednesday, 14th.-I did not go out to-day, as I had had such bad success, and was too much fatigued. A courier arrived from the Gadado, bringing intelligence of the Sheik El Kanemi being defeated with great loss, and that he had fled towards Bornou; the governors of Fudba and Zegzeg had beaten him ; and that the governor of Kano had joined them, with all his forces, in the rear. 
Duncoroa, governor of Katagum, Ben Gumso of Hadiga, \&c. were in front of the sheik, so that he will not be able to return to Bornou if they manœuvre right. The Fellatas are all in great glee on the occasion, and they do not spare him the name of Dan Caria, or son of $a b-h$.

Thursday, 15th.- Took leave of Moodie, and left Magaria after 6 A. M., sending two camels with Richard and Moodie to the village where I had halted on my way to Magaria. I proceeded along the foot of the hills, skirting the river, the bed of which is now dry in a number of places. I shot one duck and two guinea-fowls, the latter of which were very numerous; but the boys had that morning been hunting them, and they were very wild. I also saw one elephant, a number of hogs, seven of what the Arabs call the red bullock, and the people of Bornou the corigum. I take them to be the nylghau, but only a variety in colour. In Bornou they are of a dark brown; here they are of a cream colour. I shot several; they are of the antelope tribe, very fierce when wounded, and will give battle when attacked. At sunset I returned, and had a plentiful supply of pudding from the old malem; and the guinea-fowls and duck feasted all hands.

Friday, 16th.-At daylight started, and rode on to the Sanson, where $I$ arrived at $10 \mathrm{~A}$. M. The sultan sent, as soon as I arrived, to ask how I was, and to tell me he wished to see me next day. The messenger between him and me, since the Gadado is gone, is old Yargoorma, who acts in that capacity when the Gadado is here. She also sits up all night in the room he sleeps in, and keeps his fire alight. She is a shrewd old woman, of strong natural sense; and has apartments in the Gadado's house, and also in the sultan's, and possesses upwards of forty male and female slaves, though herself a slave. This possessing slaves and property is not uncommon for slaves here, which, if they have no children, go at their death to their master. 
Saturday, 17th.-Clear and warm. At 3 A. M. old Yargoorma came and told me the sultan wished to see me. I went, and found him alone. He asked after my health, and if my exercise in hunting had cured me of the spleen, which is considerably reduced, and I am now free from pain. He also asked after Richard, my servant; if his legs and feet had got better; a disorder of which he is also cured. The feet and ankles first swell, and cause great pain, not being able to walk ; then it proceeds to the calves of the legs, knees, and thigh-joints. Purgative medicines are of little service ; and the soles and ankles are so painful the patient can walk but with great difficulty, and great pain afterwards. The swelling is not like the scurvy, as on pressing the finger on the part it is attended with great pain, and does not leave a hollow after the finger is taken off.

I told him of the difficulty and the impossibility it was for me to get the skin, head, and feet-bones of two wild hogs, as he wished, because my servants would not touch them if I killed them. He said he would send for two, and I might either have them skinned myself, or they would bring the skins for me. I thanked him, and said I would prefer them skinned in the woods, as, were they brought to me alive, my house would be filled with idle people, and the whole town would never leave off talking about it whenever they saw me. Good, he said, and ordered a eunuch to give orders to the hunters to bring two as soon as possible. He asked me if we eat pork? I said yes, and the flesh was very good when they were well fed; we only eat it sparingly; the fat, I said, was always used for salves. I said it was much better to eat than dogs' flesh, which they sold publicly in the market at Tripoli; and all the great in Fezzan eat dogs' flesh whenever they could procure it. This account Sidi Sheik, who had just come in, confirmed. The sultan said, it was strange what people would eat: in the district of $\mathrm{Um}$ burm, belonging to Jacoba, they eat human flesh. I said I did not think any people existed on the face of the earth that eat their own 
kind as food; that certainly there were some savages in different parts of the world who eat their enemies. The sultan said he had seen them eat human flesh; that on the governor of Jacoba telling him of these people, he could hardly believe it himself; but on a Taurick being hanged for theft, he saw five of these people eat a part, with which he was so disgusted that he sent them back to Jacoba soon after. He said that whenever a person complained of sickness amongst these men, even though only a slight headach, they are killed instantly, for fear they should be lost by death, as they will not eat a person that has died by sickness; that the person falling sick is requested by some other family, and repaid when they had a sick relation; that universally when they went to war, the dead and wounded were always eaten; that the hearts were claimed by the head men; and that, on asking them why they eat human flesh, they said it was better than any other; that the heart and breasts of a woman were the best part of the body; and that they had no want of food, as an excuse for eating one another. Indian corn, millet, doura, and sweet potatoes were in plenty; that both men and women went naked, though their houses were much neater and cleaner than those of the common people of Soccatoo; that, excepting this bad custom, they were very cleanly, and otherwise not bad people, except that they were Kaffirs; that he would make me a present of some of them to let the king of England see that such was the fact. I said, I would rather be excused taking them, as both the king and the people of England would be too much disgusted at seeing such a sight. You will see them, he said, when you go to Jacoba: he would write to the governor to show them to me when I went. I then told him I wished as soon as possible to go to Jacoba, as I had been here now five months very idle. He said that the rebels of Zamfra had sent to beg for peace, and that, as soon as their sultan or chief arrived, he would send me through that part of Zamfra which I had not seen, and I should 
see the gold ores said to be there; that I should also see Adamawa and the Shari; and that he would send me afterwards to the sea, by the way of a country called Kano, bordering on the sea, and going to the south of the province of Zegzeg, and whose sultan had sent a messenger a short while after I left Soccatoo on my former journey, wishing to open a trade with Houssa. I said that the sooner he could send me the better, as he would have every thing that he could wish from England much cheaper than he could have by the way of the desert. He asked me again who the eleven slave-dealers were that his cousin, Mohamed Ben Abdullah, had taken at his camp at Nyffé; and if I knew that they were Christians. He said they were black; and had come from, or by the way of Borgoo; and what ought to be done with them; for Abdullah had seized them, and written to know what he should do with them. I said, he had better either take their goods, and send them away home, or have them brought up here; that they were not Christians, but I thought natives of Dahomey, and part of the same gang I had seen at Wawa in Borgoo; as it was common for the Mahomedans to call all persons, not agreeing with them in faith, Christians or Jews. After this I took leave; and in the evening he sent me a fine fat sheep, and two pomegranates from his garden.

Monday, 19th.-A courier from the Gadado arrived at Kano with a letter to the sultan, informing him of the defeat of the sheik of Bornou, and his retreat, with the loss of all his baggage, camels, and tents, two hundred and nine horses, and a number of slaves. The sultan sent me the letter to read, and the sheik's waterpot, made of copper. This is an article of the first importance to a Mahomedan great man; he never travels without one. It had been cut in three different places by a sword, not in taking it, as it was found in the tent, but hacked by some of them to vent their rage on the poor pot, as they could not do it on the sheik.

Saturday, 24th.-At day-break the pagans whom the sultan had 
sent to kill and skin a wild boar for me arrived with the skins of a boar, a sow, and one of their young ones. All the idle people in the neighbourhood had come to have a peep, as did several of the better sort of people, some of whom sat down to see me and the poor pagan, whose name is Whidah, and his sons go through the operation of salting and packing the skins. They asked Whidah if he eat the flesh? He answered, Yes, and very good it is too. It is quite ridiculous to see how much those people dread even to touch any part of the animal's skin, and know not for what reason, only because they have heard others say so. I told them it was better meat than dogs' flesh, which the people of Fezzan and those of Tripoli eat; and at Tripoli dogs' flesh was publicly sold in the market; true they were Moslem, and had not a pig, which was more cleanly in its eating, and better to be eaten than a dog. My servants, the ignorant rascals, would not come near, and if there had been others to be hired, I would have paid them off. I first strewed the poison slightly over the inner part of the hides, then plenty of finely pounded salt, and made Whidah and his sons rub all well in, strewed them over with dried grass, and packed each separately in a mat, and gave them in charge to Whidah, to have them properly dried, and to take the flesh off the bones of the heads. 'The news soon got to the market that I had such things in my house; and on sending to the market to buy three new mats, the owner said he would sell them to me, but would not bring them to my house; and now the pigs and $I$ are the whole talk of Soccatoo.

Sunday, 25th.-Divine service. Nothing worth remarking has happened since the 25th, except that I was laid up for the last four days with ague.

Wednesday, 28th. - Paid Malem Mohamed 20,000 cowries for his writing me an account of the country between Soccatoo and Masina, and Kano and Sennar, and making a chart of the river Quorra, between Cubbie and Masina. 
Sunday, 11th March, nothing worth noting down, until the 12th, when a messenger of the governor of Boushi arrived, bringing with him part of the spoil taken from the sheik of Bornou, which consisted of an old Bornou tent, a horse, and two mares, with two drums. The tent was erected in the square in the front of the sultan's house, and two slaves set to beat the drums; the whole population of Soccatoo came to see them, and they continued beating all night. The sultan sent for me. I went, and found him alone, and appearing very good humoured with the news that had arrived. After my asking after his health, and just beginning to ask if he would send me as soon as convenient to Adamowa, and to write to the governor to allow me to proceed up the Shari as far as possible, and show me every thing worth seeing in that province; and after that, if the governor of Adamowa thought it safe, he would send me to Boushi, without coming back to Kano; and that from Bonshi I would proceed to Zari, and wait until after the rains, and then proceed with his messenger to the other Kano and the seabefore he could give me an answer, a number of the principal people of Soccatoo came in, and interrupted the conversation; so I took ny leave, he appointing another day to give me the information I requested.

(Note.-Here Clapperton's Journal finishes, and no notices of any kind appear among his papers subsequent to the above-mentioned date; but the following Journal, kept by his faithful servant, Richard Lander, amply supplies the deficiency.) 


\section{J O U R N A L}

or

\section{RICHAR D LA NDER,}

SERVANT TO THE LATE

CAPTAIN CLAPPERTON. 



\section{JOURNAL, \&c.}

FROM KANO TO SOCCATOO.

Novenber 20, 1826. - The sultan sent a messenger for me this morning, and after waiting in a coozie an hour, I was introduced to him. He informed me of his having received a letter from my father (after the death of Dr. Morrison I always passed for my master's son), desiring him to send me to Soccatoo, with the whole of the property intrusted to my care. I had myself received a letter from my master only two days previously, in which he expressed no such intention; but, on the contrary, said he should be with me shortly. In that letter he complained of a violent pain in his side, to whiclı he had been for some time subject; and 1 fancied, by his not writing me to-day, he had died; and that, from motives of delicacy, the king had withheld the news from me.

22d.- The sultan again sent for me, and said he would make my father a present of five pack bullocks to convey the goods to Soccatco, and send four men to take charge of them on the road; at the same time wished me to leave on the 25th.

24th.-Paid my respects to the sultan in the morning; remained with him upwards of an hour; and on leaving, he said in a feeling tone, shaking hands with me at the same time, "Good bye, little Christian; God take you safe to Soccatoo." He sent a letter by me to my master, and desired me to give his compliments to the ling of the Mussulmans (sultan Bello, who was invariably designated by that appellation). On returning to my house, found Hadji Hat Sallah waiting for me. He told me it was necessary I

L L 
should take the whole of my master's money, which consisted of 212,000 cowries, to him. As this could not be done conveniently without a camel, I purchased one for $6 \%, 000$ cowries.

25th.-At half-past seven in the morning, left my house, accompanied by old Pascoe, a messenger from sultan Bello, and one from the king of Kano. Could not, however, get without the gates of the city till ten, the bullocks being very restive, and throwing off their burdens repeatedly. At one o'clock halted at Zungugwa: the camel, in endeavouring to enter the gate, unfortunately broke two boxes in which was stationery, \&c. This accident detained us an hour outside the walls, and the inen were ultimately obliged to carry the goods on their heads to the residence of the chief, which was a quarter of a mile's distance. I waited on him, and gave him a pair of scissors, fifty needles, and a small paper of cloves, which pleased him highly. The chief slowed me into one of his best huts, where, he told me, I might remain till I thought proper to leave the place; and shortly afterwards sent me butter, sour milk, a couple of fine fowls, and tuah and corn.

26th.-At six in the morning left the hut of this hospitable chief; and, after a ride of six hours, came to Markee, a large, but rather thinly inhabited village. 'The chief, a kind-hearted old man, upwards, I should suppose, of ninety years of age, and very feeble, was delighted to see me, and testified the pleasure he felt by shaking hands with me repeatedly, and by doing me many acts of kindness. He presented me with fowls, rice, corn, and tuah. After a little conversation, he took me into an inner apartment, and bidding me to sit, took from a calabash, which was suspended to a piece of wood attached to the roof, a small box made of skin, round which was wound, with the greatest care, upwards of five hundred yards of thread, which occupied him twenty minutes in taking off. In this box he showed me four bits of tin, about the size of swan and common shot, which he told me were silver. The old chief gave 
me to understand, with much seriousness and earnestness of manner, that they had been given by an Arab fifteen years before, who told him they were possessed of life. The larger pieces, he continued, were males, and the smaller females; and were to produce young at the end of every twelve years, before which time they were by no means to be looked at. He had enveloped them in a quantity of cotton-wool, in order to impart warmth to them; and the thread was tied round the box that the offspring might have no opportunity of escaping! "But," said the old man, with a disappointed air, "though I kept them with the greatest care for twelve years, suffering no one to approach them, I found, to my sorrow, at the expiration of that time, they had made no increase; and I begin to fear they never will :" in saying which the old man was so grievously affected that he burst into tears. It was with considerable difficulty I could refrain from laughing aloud in his face. I succeeded, however, in subduing the great inclination I had to be merry; and told him, with all the solemnity the occasion deserved, that the Arab was a rogue, and had deceived him; that the articles were bits of tin, and not of silver; that they were without life, and therefore could not produce young. I consoled the old gentleman on the hoax that had been played off upon him, and sympathized with him in his sorrow. He soon afterwards became more composed, although at times he could not help sobbing audibly. After answering the numerous questions he put to me about my country, \&c. I complained of fatigue, and retired to rest. Ill with dysentery all day.

27th.-Passing a very restless night, got up at six in the morning and proceeded on my journey. At 10 A. M. passed close to a large Fellata town, called Kaowah, in the neighbourhood of which were numerous herds of cattle grazing. Here, as in other parts of Houssa, the cows are mostly white; and the sheep gene- 
rally white, with black and red spots, which had a very agreeable appearance at a distance, and put me strongly in remembrance of Jacob's spotted sheep, mentioned in Scripture. A ride of four hours brought us to Goguay, a large walled town. The beasts were unable to enter the gate with their loads, by reason of its extreme narrowness; and being ill, and much in want of rest, I was unwilling for so much time to be consumed in conveying them into the town on men's heads: I accordingly reposed for the night underneath the branches of a large tree. On learning of my arrival, the chief came to see me, seated himself by my side, and entered familiarly into conversation. He observed that tigers abounded in the neighbourhood, and advised me by all means to keep fires burning the whole of the night round my attendants and cattle, to prevent their being attacked by those rapacious animals, which would very likely be the case if that precaution were not used. The chief told me that about two years before the Gooberites took and plundered his town, and put to the sword nearly the whole of its inhabitants, he himself very narrowly escaping with his life. This was no doubt the reason of the scantiness of the population, and the poverty of the chief and his remaining subjects. As soon as the chief left me, a new married couple paid me a visit. I gave the bride, a very pretty girl of eighteen, guinea nuts to the value of one hundred cowries, for which she dropped on one knee, and thanked me in a graceful and becoming manner. I shortly afterwards received some butter-milk from her, which was a welcome present.

28th._Left Goguay at half-past six in the morning, and halted at Kookay, a small wretched looking village, at twelve at noon. The chief sent provisions for myself and people, and provender for the eattle; and the inhabitants complained sadly of the mischief done to their crops by wild pigs, a great part of which was completely 
destroyed. 'They were miserably clad, and exhibited signs of extreme poverty. This night slept a little, which is a comfort I seldom enjoy.

29th. - At half-past six in the morning proceeded on our jour ney, and at twelve stopped at Duncammee, a moderately sized walled town. I was both surprised and pleased to observe the neatness of this town, and the cleanliness of its inhabitants. Every inch of spare ground was planted with tobacco, and very tastefully fenced round with dried tobacco stalks. 'The natives manufacture large quantities of cotton cloths, which are neat and durable; and at the north end of the town are several dye-pits. The wall surrounding the town is in rather a ruinous state. 'The chief welcomed me to his house, and offered me the best apartment in it. Provisions were plentiful, and we fared exceedingly well. In return for his kindness, I gave him a clasp knife, and a hundred needles.

30th.-At six in the morning were again on our route, and halted at Gaza at one at noon. 'The chief was happy to see me, lodged me in his own house, and seemed to take pleasure in obliging me.

31st.-Continued our journey at the usual hour, and halted at Rayoo at one o'clock. In this town I was considerably worse, became debilitated in a surprising manner, lost my sight, and could not rise in bed. Fancying I should not be able to proceed any further, and that my life was drawing to a close, I called Pascoe to my bed-side, and advised him, after he had buried me, to make all haste to my master at Soccatoo; to take particular care of the property he would have the charge of, and I had no doubt my master would reward him.

December 1st.- This day was dreadfully ill-unable to taste any kind of food, and expecting every moment would be my last.

2d.-Did not find myself at all better this morning, and was surprised I had lived so long. At 2 P. M., finding myself a little revived, but unable to sit up, I determined to see my dear master, 
if I could, before I died. For this purpose ordered my people to make a couch on the back of the camel; after which they gently lifted me into it, and I almost immediately ordered them to proceed. The chief of Rayoo, who was one of Bello's principal fighting men, behaved particularly kind to me, and, I really believe, sincerely sympathized in my distress. He expressed much sorrow on parting, and hinted it would be dangerous to proceed, but did not oppose my determination. The path, the greater part of the way, being very narrow, and thickly lined on each side with a species of thorn, I was annoyed greatly, by reason of the thorns frequently tearing the covering from my bed, and exposing me to the intense heat of a burning sun. The sultan of Kano's messenger, however, seeing me in this state, rode before the camel, and dexterously lopped off the overhanging branches with his cutlass: this proved of the utmost advantage. 'The violent shaking of the camel caused me to be faint several times on the road; on which occasions my party uniformly halted until I revived. In this manner we journeyed till seven in the evening, when we entered a walled town called Koolefee. The chief, a very fine old man, never having seen a white man before, was in raptures when he learned of my being in the town; and running to the camel, took me from its back, and carried me in his arms into an apartment which had been hastily prepared for my reception. Placing me on a bed, he took a gora nut from his pocket, and holding it betwixt his finger and thumb, wished me to chew one end of it, that he might have the pleasure of eating with a Christian. I did it after some difficulty, when he immediately ate the remainder with much apparent satisfaction. His great men, who surrounded me, reproved him sharply for doing this. He quickly answered them, in a pleasant but firm tone, that he believed the "little Christian" was as good a man as himself or any of them; which effectually silenced their remarks. He shortly afterwards went out, and returned with a bowl, containing six 
quarts of new milk, with which a little flour and some honey had been mixed. He told me he was determined to see me eat the whole of it before he left the apartment. I partook sparingly of it at first, but in the night tasted it several times, which refreshed and invigorated me.

3d.-Finding myself considerably better this morning, I ordered a pillow to be laid across my horse's saddle, that I might travel for a short distance on his back. Entered a miserable village named Zunko, and slept there for the night.

4th.-Arose at sun-rise, and after a fatiguing journey reached Roma at two in the afternoon. This town is built on an eminence, and commands a delightful view of the country for miles round. Proceeded to the house of the chief, and slept there. He made me the accustomed presents of provisions, \&c. and received in return a pair of scissors, a hundred needles, and a paper of cloves. Several Fellata girls came to me this evening, of a bright copper colour, and extremely beautiful, with delicate and graceful forms. With a curiosity so natural to their sex, they were all eager to catch a glance of the "little Christian," having seen the "great Christian," as they termed my master, before. In the course of the afternoon. and evening they bronght me a little milk and butter, for which I recompensed them with a fer beads. Here, I am happy to say, the dysentery quite left me, and my health wonderfully improved. 5th.-Left Roma for Bogell early in the morning, and arrived there at half-past four in the afternoon. Found myself so well today that I was enabled to ride on horseback the whole of the journey. As usual, went to the residence of the chief, who gave me a little corn for the horses only. In the night slept profoundly, and next morning was completely recovered.

6th.-At six in the morning left for Zulamee, where we arrived at two in the afternoon. The chief was overjoyed to see me, and ordered four armed men to guard the beasts and property. A band 
of robbers having infested the town for some time, and committed numerous depredations, he was fearful some of my goods or cattle would be stolen, and desired me to fire a gun morning and evening, that the brigands might not think I was unprepared to meet them. They did not, however, molest me; but the king of Kashna was not quite so fortunate: he had a fine horse stolen from him yesterday, which he never afterwards recovered. Rested here two days, in order to recruit the spirits of my followers, and refresh the animals under their charge.

9th.-At six in the morning, having got every thing in readiness, left Zulamee. Both men and beasts seemed much invigorated with the rest they had enjoyed, and at two in the afternoon reached Gundumowah, a small but neat Fellata village. The chief sent me a little milk.

10th.-- Early in the morning started for Sansanee. 'The country traversed was thickly wooded, and the path lay for three hours through a large bush, which, having recently been visited by a horde of elephants, the prints of whose feet were very perceptible, rendered travelling extremely umpleasant, and even dangerous. Reached Sansanee at one at noon. The site on which the town is built not being long cleared, none of the houses were quite finished. On our arrival, the chief had an open shed, occupied by fifteen calves, cleaned out for our reception. In the evening, putting the goods in the centre, I ordered the men to lie around them, whilst I placed myself near the most valuable articles. Not deeming them sufficiently secure, my sleep was rather disturbed; and awaking about ten o'clock, I found my camel had strayed from outside the hut, and being unwilling to arouse my drowsy companions, went myself in search of him. On my return, to my infinite surprise and alarm, discovered Pascoe had decamped, taking with him a valuable gun, two pistols, a cutlass, six sovereigns, nineteen dollars, ten large and ten small knives, and several other articles, which he had contrived 
to take from the boxes in which they had been placed. To deceive me, the artful old villain had put a pillow into a sack, which he had laid along on his own mat. On the discovery, I immediately made an alarm, and sent to the chief for twelve horsemen to go in pursuit of him.

11 th. - About three o'clock in the afternoon, as I was standing in my shed, I perceived a party of horsemen coming towards me in full gallop. On coming within a few yards of me, they suddenly checked their horses, and flourishing their spears over their heads, exclaimed, "Nasarah, acqui de moogoo!" (Christian, we have the rogue!) They informed me that a little before day-break in the morning they heard the report of a gun, and going towards the place whence the sound seemed to proceed, saw Pascoe perched on the top of a high tree, and the stolen goods lying at the root of it. 'They threatened to shoot him with their poisoned arrows unless he immediately came down. 'This had the desired effect. He hastily descended, and delivered himself into their hands. One of the soldiers took the trembling scoundrel behind him on his horse, when the whole party immediately clapped spurs to their horses, and made all the haste they could to the village. I asked Pascoe what could have induced him to leave me in so disgraceful a manner. He replied that his countrymen (the Gooburites) were at war with the Fellatas, who would cut off his head on arriving at Soccatoo. 'The chief coming up at the instant, cried out, "A blessing, a blessing; you have taken the thief, let me take off his head!" This was Pascoe's third offence; and I ordered him to be heavily ironed and pinioned in the town dungeon.

12th.-Pascoe having expressed a wish to see me, I sent for him. He begged most piteously to be forgiven, and holding up his naked arms, which were swollen to thrice their natural size, implored me at least not to have him pinioned again. This I freely 
consented to, but he was not freed from his irons till the morning we left the town.

13th. - This day 500 camels laden with salt, obtained from the borders of the Great Desert, arrived at the town. They were preceded by a party of twenty Tuarick salt-merchants, whose appearance was grand and imposing. They entered at full trot, riding on handsome camels, some of them red and white, and others black and white. All the party were dressed exactly alike. They wore black cotton tobes and trousers, and white caps with black turbans, which hid every part of the face but the nose and eyes. In their right hand they held a long and highly-polished spear, whilst the left was occupied in holding their shields, and retaining the reins of their camels. 'The shields were made of white leather, with a piece of silver in the centre. As they passed me, their spears glittering in the sun, and their whole bearing bold and warlike, they had a novel and singular effect, which delighted me. They stopped suddenly before the residence of the chief, and all of them exclaiming, " Choir!" each of the camels dropped on its knees, as if by instinct, whilst their riders dismounted to pay their respects. They came in a body to see me just after, and notwithstanding their apparent respectability, felt not the least repugnance to beg money in a most importunate manner. One of them, in the hope of obtaining some, described himself as "God's own slave." I refused to accede to his request, observing, that God always loved his servants, and made them prosperous and happy, and could not believe what he had told me. Becoming at length very troublesome, I was under the necessity of turning him ont: as he went away, he muttered something I did not understand, and said, I was the first person that ever refused to give him money. Like thousands of others, these merchants were very inquisitive, and amongst other questions asked whether any of my countrymen had tails like 
monkeys? I assured them none of them had that elegant appendage, but they would not believe me. After remaining an hour, they went to look after their wives and children, who were on the camels on the road, and not yet arrived.

14th.-. The goods being properly secured, I took my gin this morning and shot enough of pigeons for dinner. 'The Tuarick men, women, and children, surrounded me in great numbers on hearing the report of my gun, and were amazed to see the birds falling dead at my feet from the tops of the high trees. They examined them with great attention, declaring I was a beautiful man, too good for a Kafer, and ought to be a worshipper of the true faith.

16th. - In the afternoon an escort, consisting of fifty armed horsemen sent by Bello, arrived, to conduct me to Soccatoo. They brought with them my master's two camels, to carry the goods, which, as I afterwards learnt, the Gadado had borrowed under false pretences. A messenger belonging to the sultan of Kano brought a letter from my master, unknown to the escort, and was on his way to Kano with it. The letter informs me of the total ignorance of my master of my having left Kano, and his expectations of seeing me there in a week or two. It struck me forcibly at the time that Bello wished to get me in his power, in order to put us out of the way, to become the sole possessor of the sheik of Bornou's presents, \&c. As soon as I had read the letter, $\mathbb{I}$ asked the Gadado's brother, who commanded the escort, if it was the sultan's intention to murder us on my arrival at Soccatoo, as my master knew nothing of the transaction. He answered, "Fear nothing, the king will not hurt you; as he has never seen but one Christian, he wishes to view a second."

17th and 18th.- The Gadado's brother came to me several times for money to buy goora nuts. I at lengtli told him the money in my possession belonged to my father, who would not 
permit me to part with any, unless I had previously obtained his consent. This answer by no means pleased him : but on my telling him he should be handsomely rewarded on our safe arrival at Soccatoo, he became a little appeased.

19th.-Liberated old Pascoe in the morning, who had behaved peaceably since his imprisonment, and seemed truly sorry for the offence he had committed; and at two in the afternoon went out of the town, but was obliged to leave a bullock behind, being lamed and mable to proceed. Travelled till eleven o'clock the next night, when we arrived much fatigued at Magaria. The poor camels and horses could hardly stand, and suffered dreadfully from thirst, not having drank during this long journey.

21 st and 22d.-The horses and camels not being sufficiently recovered to continue the journey, staid at Magaria both these days. Resided at a house belonging to the Gadado, who supplied me with abundance of provisions. Received a message from him to come to see him, with my gun, in order to show the head men of the town the manner in which birds were shot in my country. I soon gratified their curiosity by firing at a small bird, at a distance of fifty yards. The whole of them testified the greatest astonishment on taking it up, and would not for a long time believe it was really dead.

23d.- To my great joy I entered the gates of Soccatoo in the afternoon, about two o'clock, after a tedious and wearisome journey of nearly a month. Not having seen my master for three months, I hastened to his house; but not finding him at home, I went to the Gadado's, where, I was told, he had gone. My master was in earnest conversation with the Gadado and an old Arab, and was much surprised when informed of the reason of my leaving Kano: he spoke with warmth of the artful and unhandsome conduct of the sultan; and after this act of duplicity on the part of 
Bello, to the hour of his death, I never observed him to smile. My master had been ill of dysentery before my arrival, but was then much better.

RESIDENCE AT SOCCATOO-MY MASTER's DEATI-BURIAL.

On the 13th December, the day after my arrival, Sultan Bello sent for my master and myself to repair to his residence. As soon as we entered, he began to make inquiries of the nature of the presents I had with me, and was extremely desirous to know if I had left any with Hadji Ben Sallah for the sheik of Bornou. I replied, I had not. "Are you sure you have not?" said he. I again answered with firmness in the negative. The sultan then demanded the king of England's letters to the sheik of Bornou, which my master reluctantly produced; but refused to accede to the sultan's request to open and read them, observing that, when his king discovered, on his return to his country, he had so unfaithfully broken his trust, he would immediately be beheaded. The sultan himself took the letters, and waving his hand for us to withdraw, we left the apartment. We had not been in our hut more than a couple of hours when the Gadado, his brother, Hadji Ben Sallah, and several of the principal inhabitants of Soccatoo, entered, and demanded, in the name of Bello, the presents intended for the sheik of Bornou, together with all the arms and ammunition we did not want ourselves. My master became deeply agitated when he had heard their errand, and rising up from his couch, exclaimed with much energy and bitterness-_"There is no faith in any of" you; you are an unjust people; you are worse than highway robbers." 'They cautioned him to be more guarded in his expressions, or it might cost him his head. "If I lose my head," rejoined my 
master in the same determined manner, " 1 lose it for speaking for the just rights of my country only." Ben Sallah and other's entreated him to moderate his anger, or it might indeed be fatal to him. I also implored him to accede to the demands of the sultan, how unjust and tyramnic soever they might be, observing, that two debilitated white men stood no chance in holding out against the winited force of so many Fellatas, who only waited the command of their sovereign to assassinate them. After much entreaty, and not without considerable reluctance, my master desired that they should be given to them; and said to the Gadado, on his leaving the hut, "Tell your sovereign I never wish to see him again; my business with him is now at an end." A short time after Mallam Mudey returned with a message from the sultan, acquainting my master of his intention of writing to the king of England in explanation of his conduct. He desired Mallam Mudey to tell Bello that the king of England would not even look at a letter from him, after the treatment his subjects had received.

I took an opportunity one clay of acquainting my master of Pascoe's villany, who immediately dismissed him, without paying his wages. 'The old man went to a native lawyer to obtain advice in what manner he was to act; but instead of holding out the hope of obtaining the sum due to him, the learned Fellata expressed his astonishment that Abdullah had not cut off his head. Pascoe then turned snuff-merchant; but having given too extensive credit, soon became a bankrupt, and was finally obliged to cut wood from the adjoining country, and sell it in the market at Soccatoo, by which means he contrived to procure a precarious subsistence.

One day the Gadado came and begged me to lend him my camel to go to the war against the sheik of Bornou: knowing it would be impolitic to refuse, I let him have it. The animal was returned to me, about six weeks after, in a most shameful state, reduced 
to a mere skeleton, and having two immense holes in its back. I wished the Gadado to give me another in its stead, but he would not listen to me.

My master and myself enjoyed pretty good health for some time after my arrival at Soccatoo, and amused ourselves with going a shooting almost every day. At one shot my master brought down thirteen wild ducks, about two miles to the north-east of the city, ten of which were secured. We remained at Soccatoo much longer than was intended, believing the sultan would consent to our proceeding to Boinou when the war had become somewhat abated; but this he never granted.

On the 12th of March, 1827, I was greatly alarmed on finding my dear master attacked with dysentery. He had been complaining a day or two previously of a burning heat in his stomach, unaccompanied, however, by any other kind of pain. From the moment he was taken ill he perspired freely, and big drops of sweat were continually rolling over every part of his body, which weakened him exceedingly. It being the fast of Rhamadan, I could get no one, not even our own scrvants, to render me the least assistance. I washed the clothes, which was an arduous employment, and obliged to be done eight or nine times each day, lit and kept in the fire, and prepared the victuals myself; and the intermediate time was occupied in fanning my poor master, which was also a tedious employment. Finding myself unable to pay proper attention to his wants in these various avocations, I sent to Mallam Mudey, on the 13th, entreating him to send me a female slave to perform the operation of fanning. On her arrival $\mathbb{I}$ gave her a few beads, and she immediately began her work with spirit; but she soon relaxed in her exertions, and becoming tired, ran away, on pretence of going out for a minute, and never returned. Alla Sellakee, a young man my master had purchased on the road from Kano to take care of the camels, and whom he had invariably treated with his usual 
kindness, and given him his freedom, no sooner was made acquainted with his master's illness than he became careless and idle, and instead of leading the camels to the rich pasturage in the vicinity of Soccatoo, let them stray wherever they pleased, whilst he himself either loitered about the city, or mixed with the most degraded people in it: by this means the camels became quite lean; and being inforned of the reason, I told my master, who instantly discharged him from his service.

My master grew weaker daily, and the weather was insufferably hot, the thermometer being, in the coolest place, 107 at twelve in the morning, and 109 at three in the afternoon. At his own suggestion I made a couch for him outside the hut, in the shade, and placed a mat for myself by its side. For five successive days I took him in my arms from his bed in the hut to the couch outside, and back again at sunset, after which time he was too much debilitated to be lified from the bed on which he lay. He attempted to write once, and but once, during his illness; but before paper and ink could be brought him, he had sunk back on his pillow, completely exhausted by his ineffectual attempt to sit up in his bed. Fancying by various symptoms he had been poisoned, I asked him one day whether he thought that, in any of his visits to the Arabs or 'luaricks, any poisonous ingredients had been put into the camel's milk they had given him, of which he was particularly fond. He replied, "No, my dear boy; no such thing has been done, I assure you. Do you remember," he continued, "that when on a shooting excursion at Magaria, in the early part of February, after walking the whole of the day, exposed to the scorching rays of the sun, I was fatigued, and lay down under the branches of a tree for some time? 'The earth was soft and wet, and from that hour to the present I have not been free from cold: this has brought on my present disorder, from which, I believe, I shall never recover." 
For twenty days my poor master remained in a low and distressed state. He told me he felt no pain; but this was spoken only to comfort me, for he saw I was dispirited. His sufferings must have been acute. During this time he was gradually, but perceptibly, declining; his body, from being robust and vigorous, became weak and emaciated, and indeed was little better than a skeleton. I was the only person, with one exception, he saw in his sickness. Abderachman, an Arab from Fezzan, came to him one day, and wished to pray with him, after the manner of his countrymen, but was desired to leave the apartment instantly. His sleep was uniformly short and disturbed, and troubled with frightful dreams. In them lie frequently reproached the Arabs aloud with much bitterness; but being an utter stranger to the language, I did not understand the tenor of his remarks. I read to him daily some portions of the New Testament, and the ninety-fifth Psalm, which he was never weary of listening to, and on Sundays added the church service, to which he invariably paid the profoundest attention. The constant agitation of mind and exertions of body I had myself undergone for so long a time, never having in a single instance slept out of my clothes, weakened me exceedingly, and a fever came on not long before my master's death, which hung upon me for fifteen days, and ultimately brought me to the very verge of the grave. Finding myself unequal to pay that attention to my master's wants which his situation so particularly required, I solicited and obtained his consent to have old Pascoe once more to assist me. On entering the hut, he fell on his knees, and prayed to be forgiven, promising to be faithful to my master's service. Master immediately pardoned him, and said he would forget all that had passed, if he conducted himself well: by this means the washing and all the drudgery was taken from my shoulders, and I was enabled to devote all my time and attention to my master's person. I fanned him for hours together, and this seemed 
to cool the burning leat of his body, of which he repeatedly complained. Almost the whole of his conversation turned upon his country and friends, but I never heard him regret his leaving them ; indeed he was patient and resigned to the last, and a murmur of disappointment never escaped his lips.

On the 1st of April, he became considerably worse, and though evidently in want of repose, his sleep became more and more disturbed. He swallowed eight drops of laudanum, four times a day, for three days; but finding it did him not the least benefit, he discontinued taking it altogether: this, with the exception of two papers of Seidlitz powders and four ounces of Epsom salts, was the only medicine he had during his illness. On the 9th, Maddie, a native of Bornou, whom master had retained in his service, brought him about twelve ounces of green bark from the butter tree, and said it would do him much good. Notwithstanding all my remonstrances, master immediately ordered a decoction of it to be prepared, observing, "No man will injure me." Accordingly Maddie himself boiled two basins-full, the whole of which he drank in less than an hour. Next morning he was much altered for the worse, and regretted his not having followed my advice. About twelve o'clock of the same day, he said, "Richard, I shall shortly be no more; I feel myself dying." Almost choked with grief, I replied, "God forbid, my dear master : you will live many years yet." "Don't be so much affected, my dear boy, I entreat you," said he : " it is the will of the Almighty; it cannot be helped. Take care of my journal and papers after my death; and when you arrive in London, go immediately to my agents, send for my uncle, who will accompany you to the Colonial Office, and let him see you deposit them safely into the hands of the secretary. After I am buried, apply to Bello, and borrow money to purchase camels and provisions for your journey over the desert, and go in the train of the Arab merchants to Fezzan. On your arrival there, should your 
money be exhausted, send a messenger to Mr. Warrington, our consul at Tripoli, and wait till he returns with a remittance. On reaching Tripoli, that gentleman will advance what money you may require, and send you to England the first opportunity. Do not lumber yourself with my books; leave them behind, as well as the barometer, boxes, and sticks, and indeed every heavy article you can conveniently part with; give them to Malam Mudey, who will take care of them. The wages I agreed to give you my agents will pay, as well as the sum government allowed me for a servant ; you will of course receive it, as Columbus has never served me. Remark what towns or villages you pass through ; pay attention to whatever the chiefs may say to you, and put it on paper. The little money I have, and all my clothes, I leave you : sell the latter, and put what you may receive for them into your pocket; and if, on your journey, you should be obliged to expend it, government will repay you on your return." I said, as well as my agitation would permit me, "If it be the will of God to take you, you may rely on my faithfully performing, as far as I am able, all that you have desired; but I trust the Almighty will spare you, and you will yet live to see your country." "I thought I should at one time, Richard," continued he; " but all is now over; I shall not be long for this world : but God's will be done." He then took my hand betwixt his, and looking me full in the face, while a tear stood glistening in his eye, said, in a low but deeply affecting tone, "My dear Richard, if you had not been with me, I should have died long ago; I can only thank you, with my latest breath, for your kindness and attachment to me, and if I could have lived to return with you, you should have been placed beyond the reach of want; but God will reward you." 'This conversation occupied nearly two hours, in the course of which my master fainted several times, and was distressed beyond measure. The same evening he fell into a slumber, from which he awoke in much perturbation, and said he $\mathrm{N}$ N 2 
had heard with much distinctness the tolling of an English funeral bell : I entreated him to be composed, and observed that sick people frequently fancy they hear and see things which can possibly have no existence. He made no reply.

About six o'clock in the morning of the 11th, on asking how he did, my master answered he was much better, and requested me to shave him. He had not sufficient strength to lift his head from the pillow; and after finishing one side of the face, I was obliged to turn his head, in order to shave the other. As soon as it was done, he desired me to fetch him a looking-glass which hung on the other side of the hut. On seeing himself in it, he observed that he looked quite as ill at Bornon, on his former journey; and as he had borne his disorder so long a time, he might yet recover. On the following day he still fancied himself getting better. I began to flatter myself, also, that he was considerably improved. He eat a bit of hashed guinea-fowl in the day, which he had not done before since his illness, deriving his sole sustenance from a little fowlsoup and milk and water. On the morning of the 13th, however, being awake, I was much alarmed by a peculiar lattling noise, proceeding from my master's throat, and his breathing was loud and difnicult; at the same instant he called out "Richard!" in a low and hurried tone. I was immediately at his side, and was astonished at seeing him sitting upright in his bed, and staring wildly around. I held him in my arms, and placing his head gently on my left shoulder, gazed a moment on his pale and altered features: some indistinct expressions quivered on his lips; he strove, but ineffectually, to give them utterance, and expired without a struggle or a sigh. When I found my poor master so very ill, I called out with all my strength, "O God, my master is dying!" which brought Pascoe and Mudey into the apartment. Shortly after the breath had left his body, I desired Pascoe to fetch some water, with which I washed the corpse. I then got Pascoe and Mudey to assist me in 
taking it outside of the hut, laid it on a clean mat, and wrapped it in a sheet and blanket. Leaving it in this state two hours, I put a large clean mat over the whole, and sent a messenger to Sultan Bello, to acquaint him of the mournful event, and ask his permission to bury the body after the manner of my own country, and also to know in what particular place his remains were to be interred. The messenger soon returned with the sultan's consent to the former part of my request; and about 12 o'clock at noon of the same day a person came into my hut, accompanied by four slaves, sent by Bello to dig the grave. I was desired to follow them with the corpse. Accordingly I saddled my camel, and putting the body on its back, and throwing an union-jack over it, I bade them proceed. Travelling at a slow pace, we halted at Jungavie, a small village, built on a rising ground, about five miles to the south-east of Soccatoo. The body was then taken from the camel's back, and placed in a shed, whilst the slaves were digging the grave; which being quickly done, it was conveyed close to it. I then opened a prayer-book, and, amid showers of tears, read the funeral service over the remains of my valued master. Not a single person listened to this peculiarly distressing ceremony, the slaves being at some distance, quarrelling and making a most indecent noise the whole of the time it lasted. 'This being done, the union-jack was taken off, and the body was slowly lowered into the earth, and I wept bitterly as I gazed for the last time upon all that renained of my generous and intrepid master. The pit was speedily filled, and I returned to the village about thirty yards to the east of the grave, and giving the most respectable inhabitants, both male and female, a few trifling presents, entreated them to let no one disturb its sacred contents. I also gave them 2,000 cowries to build a house, four feet high, over the spot, which they promised to dlo. I then returned, disconsolate and oppressed, to my solitary habitation, and leaning my head on my hand, could not help being deeply affected 
with my lonesome and dangerous situation; a hundred and fifteen days' journey from the sea-coast, surrounded by a selfish and cruel race of strangers, my only friend and protector mouldering in his grave, and myself suffering dreadfully from fever. I felt, indeed, as if I stood alone in the world, and earnestly wished I had been laid by the side of my dear master: all the trying evils I had endured never affected me half so much as the bitter reflections of that distressing period. After a sleepless night, I went alone to the grave, and found that nothing had been done, nor did there seem the least inclination on the part of the inhabitants of the village to perform their agreement. Knowing it would be useless to remonstrate with them, I hired two slaves at Soccatoo the next day, who went immediately to work, and the house over the grave was finished on the 15th.

One instance, out of many, of the kindness and affection with which my departed master uniformly treated me, occurred at Jenna, on our journey into the interior. I was dangerously ill with fever in that place, when he generously gave up his own bed to me, and slept himself on my mat, watched over me with parental assiduity and tenderness, and ministered to all my wants. No one can express the joy he felt on my recovery: and who, possessing a spark of gratitude, could help returning it but by the most inviolable attachment and devoted zeal? It was his sympathy for me in all my sufferings that had so powerful a claim on my feelings and affections, and taught me to be grateful to him in hours of darkness and distress, when pecuniary recompense was entirely out of the question.

The great sufferings, both mental and bodily, I had undergone at the death and burial of my master, and the constant agitation in which I was kept, occasioned a rapid increase in my disorder ; and on the 16 th I could with difficulty crawl round my hut, and was obliged to lay myself on my mat, from which I had not strength to arise till the 27th; old Pascoe, during that period, being very kind and 
attentive to me. The Arabs in the city visited me daily, and did all in their power to raise my spirits; telling me not to be disheartened at the death of my father, and that no injury would happen to me. But I plainly saw these visits of condolence did not proceed from a charitable spirit; they came more for the purpose of obtaining presents than any thing else: but I did not give them any. T'he sultan also sent messengers to inquire after my health nearly as often. The weather was dreadfully warm; and I was obliged to have a tub of water close at my side, into which I frequently plunged my hands and arms, and occasionally sprinkled my head and body. This much refreshed me; indeed it was the only means by which I was enabled to obtain a little sleep. I had given up all hopes of life, when on the 26th I found my health improve in a wonderful manner; the next day I was able to sit up on my mat. In the course of this day (27th) the Gadado, Malem Moodie, and Sidi Sheik, came with a commission from the sultan to search my boxes, as he had been informed they were filled with gold and silver; but, to their great amazement, found I had not sufficient money to defray my expenses to the sea-coast. They, however, took an inventory of all my articles, and carried it to Bello. The gold watch intended for him, and the private watches of Captains Clapperton and Pearce, I had taken the precaution to conceal about my person. In a short time the Gadado and his companions returned with a message from the sultan, commanding me to deliver to them the following articles, viz. a rifle-gun, doublebarrelled ditto, two bags of ball, a canister of powder, a bag of flints, a ream and a half of paper, and six gilt chains, for which he promised to give me whatever I might ask. I consequently charged him 245,000 cowries, which I was to receive from Hadji Hat Sallah, at Kano; and an order was given me to receive this sum, and what more I might require in my journey over the Great Desert. A letter was also sent by me to Hadji Hat Sallah. 
On the 28 th I made Ben Gumso a present of four yards of blue, and the same quantity of scarlet damask, an unwritten journalbook, two pairs of scissors, and two knives: with these articles I endeavoured to get into the good graces of this old Arab. By a singular piece of good fortune he had just begun to exercise a powerful influence over the mind and opinions of the sultan. Bello, in an excursion into the Gooberite country, had come to an engagement with a large party of the natives; and in the midst of the fight was shot in the neck with a poisoned arrow, which turned the tide of victory in favour of his enemies. On his return to Soccatoo, Ben Gunso wrote a charm on a bit of wood, which was washed off into a calabash of water, and drank immediately by the sultan; who, shortly after recovering, attributed it solely to the virtues of this charm, and he was advanced accordingly. I begged Ben Gumso to use his influence with the sultan to obtain leave for my departure from his capital, and make the best of my way homewards. He accordingly represented to Bello the impolicy and injustice of detaining any longer a subject of the king of England; advised him to allow me to quit Soccatoo as soon as possible; and insinuated that, if I were to die in his dominions, a report would be circulated and believed that he had murdered both my father and me, by which he would get a bad name. 'I'he sultan approved of these weighty arguments of Ben Gunso; and word was sent me, almost immediately, to appear before him. After a little preliminary conversation, Bello asked me which route I should prefer. Although my master had advised me to proceed with the Arabs to Fezzan, just before his death, I much feared that the papers intrusted to my care would be stolen, and myself murdered, by that wily and treacherous race, whose behaviour to my master, from the time of his arrival in Houssa, I very much disliked; and would rather cast myself, unarmed and unprotected, upon the good faith of the natives, than go with them. Under these impressions I an- 
swered the sultan that, as I wished to get to England in as short a time as possible, the route to Kubbi, through Boussa, was most likely to answer that end. "It is impossible," he continued, "to travel that way: the rainy season is commenced; the rivers are overflowed; the country is inundated; and you will not be able to reach the sea-coast in safety. It will be much better for you to go over the desert; and, to facilitate your progress, I will write Hat Sallah to get a trustworthy person to accompany you; he will also furnish you with camels and provisions, and advance you what money it is likely you will want." I only replied, "Very well, sultan." He then asked if Abdullah had forgiven Pascoe in his book, for the roguery he had committed. I said, "He had not been able to write during the whole of his sickness; and therefore nothing was stated about the matter."- " If Abdullah has not pardoned him in his book," rejoined the sultan, "your king will certainly cut off his head on his arrival in England." I assured him Pascoe would not be punished by any one, if his future conduct was good; but this the sultan was in no haste to believe; and observed, "I cannot suffer him to go with you; he shall stay here to clean and repair my guns!" this latter consideration having evidently more influence with the sultan than Pascoe's safety, which he cared nothing at all about. I then besought Bello to permit him to accompany me as far as Kano, as an interpreter; to which he rather reluctantly consented, on condition that I should procure him a horse to return, and pay him wages, on my arrival at Kano, to the amount of 15,000 cowries, which of course I agreed to do; and finding the sultan had nothing more to say, I bowed profoundly and retired. I never saw him again. 
On the evening of the $3 \mathrm{~d}$ of May, a messenger came from the sultan, and told me to get every thing in readiness to depart on the following morning, with a promise of a camel and provisions, which I never received. Early next day, therefore, I left Soccatoo, where I had suffered so much, heartily tired of the place and its inhabitants; and, accompanied with a messenger from the kind old Gadado, Pascoe and Mudey, with our three camels and two horses, proceeded to a flat, five miles to the east of Magaria, where we arrived in the afternoon, and rested for the night under the branches of a large tree, near to a small lake. Mosquitoes were numerous and troublesome, and consequently could not sleep till morning, when a refreshing breeze springing up, it drove them away. At this flat we joined a party of above 4,000 people, consisting of Tuarick salt-merchants returning to Kilgris, pilgrims on their way to Mecca, Goora merchants returning to Kano and Nyffé, \&c. \&c.; all travelling in company, for mutual protection, with an immense number of camels, horses, and bullocks. The merchants invariably meet at Kashna, where they disperse for their different destinations. In the same train was the king of Jacoba, with fifty slaves, which he had driven to Soccatoo, as a present to the sultan, who, having learnt the dreadful losses he had sustained in men and cattle in his wars with the sheik of Bornou, and the number of his villages which had been plundered and burnt by the soldiers of the sheik, would not accept of them, and desired the king of Jacoba to re-conduct them to his own dominions.

At elevell o'clock in the morning of the 4th of May, a signal to prepare to depart was made with the horns and drums of the party, which made a loud and most discordant noise; and, about an hour after, the whole body was in motion. IVe travelled in great haste 
till three o'clock in the afternoon of the 5th, when Boussa Jack, the horse on which I rode, and which was made a present of by the king of Boussa to my late master, became much fatigued, and began to lag. The weather was at this time intolerably hot, and the dust was rolling in thick clouds in every direction, entering my eyes and nostrils, and penetrating into the very pores of the skin. I felt nearly suffocated, and was faint and exhausted. Finding I was unable to proceed, I ordered Pascoe to overtake the camels, his horse being fresh and vigorous, and bring me some water. I then dismounted, and sat under a tree by the road-side, whose branches afforded but an indifferent shelter against the scorching rays of an African sun, and holding the bridle of my poor horse in my hand, I implored the hundreds of Fellatas and Tuaricks who were passing to sell me a drop of water; but the cold-hearted wretches refused my earnest request, observing one to another, "He is a Kafir; let him die." At length a young Fellata, from Footatoora, accidentally seeing me, came to the spot, exclaiming, "Nasarah, Nasarah, triffi manora!" (Christian, Christian, go on!) I answered, "I am faint and sick for want of water; no one will give me any; and I am so weary that I cannot proceed." On hearing which the young man kindly gave me a small calabash full; part of which I drank, and with the remainder washed the nostrils of Boussa Jack, and sprinkled a little into his mouth. 'I'he people, who observed the Fellata performing this generous action, upbraided him in strong language for giving water to the Christian; but he, showing them a double-barrelled gun, remarked that he had obtained it of my countrymen, who were all good men, and would do no harm. This somewhat appeased them. On examining the gun shortly afterwards, I found it to be of English manufacture, with "Arnold, maker, London," on its lock. I, as well as the horse, was greatly refreshed with the small quantity of water I had taken; but soon becoming again weak and dispirited, I was almost in as 
bad a state as on the former occasion; my legs were swollen prodigiously, and I felt the most acute pains in every part of my body. At length I perceived Pascoe, whom I had sent for water three or four hours previously, comfortably seated under a tree, and seeming to be enjoying himself much with Mudey,- the camels feeding at a short distance. I had half an inclination to shoot the heartless old scoundrel, knowing as he did how keen my sufferings must have been. Reflecting, however, that the safety of my papers, and even my own life, was placed in some measure in his hands, I restrained myself, and merely asked why he did not return with the water, on which he answered, very composedly, "I was tired."

'The young Fellata who had so generously saved my life came to me on the 7 th, and informed me that the whole of the slaves of the king of Jacoba being missing, a party of horsemen had been sent in quest of them, and had just returned with the dreadful account of having seen thirty-five of their dead bodies exposed on the road; the remaining fifteen could not be found, but were strongly suspected of having met a similar fate. 'These unfortunate creatures had to carry heavy burdens on their heads the day before; and being unable to keep up with the rapid pace of the camels, were necessarily obliged to be left behind, and thus miserably perished of thirst. I congratulated myself on my own good fortune in having so narrowly escaped so horrid a death; and thanked the Almighty for having so providentially rescued me. On leaving me, I gave the Fellata a pair of scissors, and twenty flints for his gun, which pleased him highly. On our road to Kano, the king of Jacoba became very sociable with me, and was my constant companion. He pressed me very much to visit his country, where he would do all in his power to make my stay agreeable. He told me that his neighbours, the Yamyam people, who had assisted him in his war against the sheik of Bornou, were surrounded, with some of his own people, on a plain near Jacoba, by the sheik's soldiers, 
who made a dreadful slaughter of them. The fight lasted a whole day, when the Yamyams and people of Jacoba were entirely routed; he himself narrowly escaping being taken prisoner. The morning after, the surviving Yamyams repaired to the field of action, and bearing off a great number of the dead bodies of their enemies, made a fire, roasted, and ate them!

Soon after our arrival at Markee, on the 19th, the spouse of the chief, a finely formed and intelligent looking woman, aged about 22 years, came to me with tears in her eyes, and implored me to give her some magarie, as she had no child. I accordingly presented her with a couple of tea-spoonfuls of oil of cinnamon, and ordered her to put two drops of it into a pint of cow's milk, which should be taken three times a day till the whole was consumed. I told her that on my return to Markee I had not the least doubt I should have the pleasure of seeing her the happy mother of a numerous progeny. On her husband being made acquainted with the circumstance, he came and thanked me in the heartiest manner for my kindness, gave me abundance of fresh milk, fowls, rice, \&c.; telling me at the same time, that on my return from England he would give me a large sum of money, which, no doubt, he will do. Bidding them adieu the next morning, they said to me, "Christian! God send you safely to your country, and may you speedily come back to Markee."

On my arrival at Kano on the 25th of May, I delivered Sultan Bello's order and letter to Hadji Hat Sallah; but he declared, after perusing the letter, he would have nothing to do with it: he had nearly lost his head on my father's account at Soccatoo, and therefore positively refused to lend me a single cowrie. He had no objection to give, in goods and a slave, the amount of my demands on Bello, but refused to let me have any money. I accordingly received from him a strong female slave, a quantity of unwrought silk, and scarlet caps and beads. I sold my weakened and diseased 
camels for 15,000 cowries each, and discharged their keeper, Maddie. Not having sufficient money to purchase fresh camels; provisions, and presents for the chiefs on my way to Fezzan, I was necessitated to take a different route; and for that purpose purchased a horse and two asses. Bello had not forgotten to mention in his letter for Hadji Hat Sallah to send back Pascoe to Soccatoo, on his arrival at Kano. I begged of him, however, to let me take him as far as Coulfo, in Nyff'e, which he at first refused; but giving him two yards of scarlet damask, two pairs of scissors, two dollars, a large knife, and two yards of blue damask, the old Arab seemed to relax in his determination; and calling Pascoe to him, gave him leave to accompany me to Coulfo, but cautioned him to return the moment he arrived, on pain of having Jemb (the devil) sent after him. The old man came to me just after in great trepidation, every member of his body trembling like an aspen leaf, and gave me to understand, as well as he was able, the conversation he had had with Hadji Hat Sallah, and in consequence thereof, his great reluctance to quit Kano with me. I did all I could to laugh him out of his superstitious fears, but it utterly failed of the desired effect; the name of Jerrub being enough to put him in a fever. I had given the slave that Hadji Hat Salah had sold me to Pascoe as a wife. I told him that, unless he accompanied me, he should not have her. As soon as he learnt he was to be parted from the girl, all his scruples vanished, and he consented to go to Coulfo, but no farther, he having left a wife at Soccatoo, where he much wished to go. This woman, whom I had seen several times as Ben Gumso's slave, was remarkably ugly, and had had before marriage a male child, by a blind fiddler belonging to Sultan Bello's band at Soccatoo. On my asking what had induced him to marry so frightful an object, he replied, in a tone full of tenderness, it was because she loved him very much, and made the best tuah he had ever tasted: these powerful recommendations were irresistible to a man of Pascoe's 
stamp; and a very short time after he had first tasted her tuah, Ben Gumso's ugly slave became the wife of Abbou Boukir (Pascoe's native name).

On the 29th, Hadji Hat Sallah desired me to pay my respects to the king of Kano, who was then at Faniso, his country residence. I complied with his wishes, and on my leaving his majesty he said, "When you return to your own country, Christian, give the Fellatas a good name." He was not, however, kind enough to send a messenger with me, so I hired two men to accompany me as far as Funda, paying them 8,000 cowries each for their journey. 'The same day at one left Kano, and travelling at a quick pace, halted on the banks of the river Kogie, four hours' journey from that place; but being much swollen, did not dare to pass. To our great regret we found that the tent-poles had been left behind; I was consequently obliged to send back one of the hired servants after them, giving him a sword as a proof that he was sent by me; but the scoundrel never returned. It being necessary for $1 \mathrm{~s}$ to rest on the banks of the river that night, I slung the tent to the branch of a tree, and fastened the lower part to the earth. At seven in the evening it came to fall heavy rain, accompanied with the loudest thunder I ever recollect to have heard, and lightning, which continued with great violence till nine next morning. In the night, our tent becoming completely drenched and heavy, the bough to which it was attached gave way, and it fell on us as we were sitting on our mats, it being utterly impossible to sleep. We remained in this miserable plight till day-light, for no one could venture out in that dreadful weather.

30th.-As soon as things were put to rights this morning, I sent Pascoe to Kano to endeavour to bring back the fellow that had cheated me yesterday, but he had not been seen near the place; and Pascoe returned in the afternoon with the poles. 'The river was now become fordable, but, owing to the strength and rapidity 
of the current, we crossed with extreme difficulty. We had no sooner landed on the opposite side than four armed slaves from Soccatoo came up to us, and demanded 4,000 cowries of Pascoe, which Ben Gumso had lent him to defray the expenses of the marriage ceremony with his slave, the celebrated maker of tuah; and if Pascoe were unable to pay that sum, they were to take him back to Soccatoo. Pascoe informed them he had left English clothes and money in that capital worth 50,000 cowries, out of which Ben Gumso might pay himself. This answer by no means satisfied the slaves, who were about to take him away by force, when I myself paid the money demanded. This little affair being settled to the complete gratification of Pascoe, we stopped till morning on the spot. The weather during the whole of the night was just as bad as yesterday. In the evening sent Mohamed, the other hired servant, to a neighbouring village to purchase provisions; but he brought with hire a little com only.

31st.-The weather clearing up this morning about eight, we proceeded on our journey, and at two P. M. arrived at Madubie, a small walled town. The chief invited me to remain at his house, but I preferred staying in my tent, which I had fixed within the walls, close to the gate. In the evening the chief's daughter came to see me, bringing milk, a bowl of stewed beef, and tuah, sufficient for the whole of us for supper. I afterwards made her a trifling present. The weather as usual

June 1st.-Having dried our tent, at 9 A. M. journeyed till we came to the banks of the Gora, a narrow but deep and rapid river. I was much afraid the men would be washed down the stream in crossing; but at length every thing was landed on the opposite side. Passed the walled town of Bebajie at one at noon; and ordering the men to proceed ahead, I followed at some distance, being afraid the inhabitants would detain me if recognised. Half an hour after, came to a spot where are two roads, one leading to 
Nyffé, and the other to Funda. My master had said, before his death, at Soccatoo, that if I returned through Nyffé and Youriba, the inhabitants, who must have heard of our having taken presents to Sultan Bello, with whom they were at war, would certainly assassinate me; and feeling an earnest and irrepressible desire to visit Funda, on the banks of the Niger, and trace, in a canoe, that river to Benin, without hesitation I chose the Funda road. We therefore proceeded, and at $6 \mathrm{~A}$. M. pitched our tent within half a mile of the walled town of Koufa. Sent Pascoe to the town for provisions; who shortly afterwards returned with some of the inhabitants to look at the tent. 'The chief did not visit me, thinking I was an Arab on his way to Funda. I was fortunate enough to obtain a little sleep this night, for the first time since leaving Kano. The town is situated at the foot of an immense rock, on which there is not the slightest trace of vegetation, is about two miles in circumference, and pretty thickly inhabited. To the east of the town is a range of high hills, stretching from north to south as far as the eye can reach. Their sides had a most pleasing appearance, and vegetation looked green and luxuriant. Travelled in a south-east direction till ten in the morning, when our course lay more westerly.

2d.-Left Koufa at 6 A. M., the weather being rainy, and halted at the small walled town of Cookie at twelve at noon.

3d.-It began to rain at day-break, and continued without intermission till ten in the morning, when, brightening a little, we struck our tent, and started at eleven.

At 5 P. M. came near Carifo, a small walled town, similar in extent and form to those we had seen yesterday and the day before. In the course of the day crossed a large river and two smaller ones, all running in a westerly direction, but no one could tell me their names. The hills seen yesterday still on our left, and extending to the horizon.

At 9 A. M. a dreadful thunder-storm came on, with lightning 
and torrents of rain, which threatened to wash down our tent. The country traversed to-day and yesterday, though level, is picturesque and beautiful; all nature wears a gay and lively aspect: the soil rich, and of a deep red colour.

4th.-At eight this morning, after drying the tent, proceeded; and at eleven reached the foot of a high and craggy mountain, called Almena, consisting of gigantic blocks of granite, fearfully piled on each other, and seeming ready to fall to the ground below. They much resemble the rocks near the Logan-stone, in Cornwall, but infinitely larger. Mahomet, my servant, who is acquainted with the traditions of the natives of every part of this country, and had travelled far and near, gave me the following story:- 6 About 500 years ago a queen of the Fantee nation, having quarrelled with her husband about a golden stool, fled from her dominions with a great number of her subjects, and built a large town at the foot of this mountain, which she called Almena, from which it took its name." The town was surrounded with a stone wall, as the ruins which now remain plainly attest. Crossed three small streams in the day, flowing in a north-westerly direction. At 3 P. M. passed a small walled town called Gowgee; and at four halted at Gatas, which it exactly resembled. Here I met with some Kano merchants from Cuttup. The inhabitants of Gatas, discovering by some means my being a Christian, came in crowds to see me; but behaved in a quiet and orderly manner. I invited some of the most respectable of the females into my tent, which they greatly admired, and shortly afterwards presented me with milk and foorah. The natives of this, as well as every other town I have seen in this direction, are of Houssa, but tributary to the Fellatas.

5th.-At five in the morning, were again on the road, and halted at the south side of Damoy, a small walled town, at $2 \mathrm{P}$. M. The inhabitants of this town informed me that the range of hills I have mentioned extended to the salt water, and are inhabited 
by the ferocious Yamyams, whom they all declare, as did every one I had questioned on the road, to be cannibals. The Yamyams formerly carried on an extensive traffic with the Houssa men, in red cloth, beads, \&c. which they took in exchange for elephant's teeth: but five years before they assassinated a gaffle of merchants, and had afterwards eaten them; since which time the Houssa people have been shy in dealing with them.

6th. - Started at eight in the morning, and traversing a hilly and steril country, covered with small loose stones, reached the south side of a large river called by the natives Accra, at 3 P. M., running to the north-west. I was in hopes of getting into a town this day; but having a burning fever on me, and the nearest village being at some distance, we were obliged to fix the tent on the banks of the river, and remain there till morning without food of any kind.

7th.-Left at six in the morning, and proceeding in a southwest course, arrived at a walled town called Nammaleek, at twelve at noon; the north-east part of which is defended by a mountain, and the remaining parts by a high mud wall. The mountain is nearly perpendicular, and thickly covered with wood. Thousands of hyenas, tiger-cats, jackals, monkeys, \&c. inhabit it; and the terrific noise they made during the night prevented me from closing my eyes. These animals are so rapacious, that the poor inhabitants cannot keep a single bullock, sheep, or goat; in consequence of which no animal food could be obtained in the place. The chief put us into a hut, and gave us tuah, with a sauce made from the monkey's bread-fruit tree, which is most unpalatable stuff. I intended to stop a short time here, and take medicine; but the people coming in scores to see me, I had no opportunity of opening my box but in their presence, which I did not choose to do. This day, two Fellatas, messengers of the sultan of Zegzeg, unfortunately saw me, and asked where I was going. On my acquainting them, P P 2 
they immediately rode off, and, as I subsequently learnt, returned to Zegzeg, and informed the king that I was on my way to Funda with two asses, loaded with riches, and a beautiful horse, as presents to the king of that place.

8th.-At eight in the morning left Nammaleek, and keeping in a south-west direction, at the foot of a range of mountains, perceived an opening, and went through it at about twelve. Our course then lay more easterly, and crossing one large and three small rivers, whose names I could not learn, arrived at Fullindushie, the frontier town in Catica. On our journey to-day, we met, on their way to Zegzeg, as a tax to sultan Bello, from a neighbouring country, thirty slaves, men, women, and children, all apparently ill with the small-pox. The men were tied to each other by the neck with twisted bullocks' hide; but the women and children were at liberty. The inhabitants of Fullindushie were the first people I had seen in Africa who disdained to make use of any kind of dress. They laughed immoderately on seeing me; whilst I, on my part, made myself quite merry at their expense. They were soon on the most familiar footing with me, and seem an artless and goodhumoured people; but disgusting in their manners, and filthy in their persons : their sheep, goats, and poultry eat and sleep in the same hut with them, and a most intolerable stench is exhaled from all their dwellings. They do not appear to have the least affection for their offspring: a parent will sell his child for the merest trifle in the world, with no more remorse or repugnance than he would a chicken. They invariably wear a large piece of blue glass, in the shape of a semicircle, in their upper and lower lip; and a piece of red wood, about the size of a man's thumb, dangles from their ears. They rub red clay, softened with an oil extracted from the guineanut, over their heads and bodies, which by no means improves their appearance. Their features do not resemble in any way those of the Negro, but are fine and handsome, and bear great similitude to 
the European. The inhabitants make fetishes, like the natives of Yariba.

9th.-Leaving at seven in the morning, did not halt till we arrived at La Zumee, a small town, with a good population, at three in the afternoon. On my entering, perceived two men sitting under the date-tree, one of whom having a tobe on, I saluted, thinking him to be the chief; but was surprised at his telling me he was a Kano merchant, and that the person by his side was that individual. 'The chief is a mean and dirty looking old man, and had a sheep-skin covered with filth tied round his waist. After showing me a hut, and staying away two hours, he came back, and apologized for not sending me provisions, saying his wives were at work in the gardens, but that on their return I should have some: accordingly, about three hours after, they brought me a couple of fowls, and some tuah and rice; for which I gave them a pair of scissors and fifty needles. Surrounding the town is a remarkably broad and deep ditch, which appeared to have been formerly filled with water. The country in the vicinity of the town is well cultivated. The Catica or Bowchee people do not possess a single bullock.

10th.-Arose at six in the morning, and pursuing a S. W. direction, over a fine and rich country, arrived at Coorokoo, a small walled town, environed with hills, at twelve.

11th.-Started at half-past seven in the morning, and halted at twelve at noon on the north-east side of the banks of a large river, rolling to the north-west, called Coodoonia, which empties itself into the Niger, near Funda. Finding it too deep to cross, we were obliged to remain till next day without food.

12th. - Crossed the river at nine o'clock this morning, the water reaching to our chins; and immediately proceeded towards Cuttup, where we arrived after three hours' travelling. Having heard, on my route, so many different reports of Cuttup, its wealth, popula- 
tion, and celebrated market, I was rather surprised on finding it to consist of nearly five hundred small villages, almost adjoining each other; nearly the whole of which occupy a vast and beautiful plain, adorned with the finest trees. Here, for the first time since leaving the coast, I saw plantain, palm, and cocoa-nut trees, in great abundance, and in a flourishing condition; the country resembling, in a striking manner, some parts of Yariba. A considerable traffic is carried on here in slaves and bullocks; the latter are bred by Fellatas, a great number of whom reside here for no other purpose. Slaves, as well as bullocks and sheep, are exposed in the market, which is held daily; and also red cloth, gum, salt, goora nuts, trona, beads, tobacco, country cloth, rings, needles, cutlery articles, and honey, rice, milk, \&c. People from the most distant parts of the country resort here in vast numbers, to purchase these various articles. The sultan being a very great man, I thought it necessary to make him a present worthy the representative (however humble) of the king of England. I accordingly gave him four yards of blue damask, the same quantity of scarlet ditto, a print of my own gracious sovereign, and one of his royal highness the Duke of York, with several more trifling articles. In return, I received from him a sheep, the humps of two bullocks, and stewed rice sufficient for fifty men. Ten of the king's wives, on paying me a visit a day or two after my arrival, took a fancy to the gilt buttons on my jacket, which I cut off and presented to their sable majesties. Thinking them to be gold, they immediately stuck them in their ears. In this belief I took care not to undeceive them.

During my stay at Cuttup I was never in want of a bullock's hump (by far the best part of the animal, weighing from twelve to fifteen pounds), for the king invariably receives, as a tax from the butchers, the hump of every bullock they slaughtered; and one or two was sent me by his wives each day. Being in want of money, I sent to the market and informed the people I had needles and 
beads to sell; on which several buyers came into my hut and purchased freely, giving me fifteen or twenty cowries each for the needles, whilst the Arabs could only get ten at most for theirs; but whether they conceived my needles to be superior, or whether it was the desire of obtaining something of a white man, I did not learn. Unlike the princes of Houssa, Borgoo, Nyffe, Cuttumkora, and other places in the interior, the sultan of Cuttup gives his wives unrestricted liberty.

An old woman came to me one afternoon, full of grief, informing me of her having frequently been robbed of the little money she had saved from her earnings, from holes in her hut, where she had hid it, by some of her neighbours and acquaintances. She entreated me to let her have a charm to prevent such dishonest acts in future. Being ever willing to oblige the simple-hearted Africans, I gave her a tea-spoonful of common sweet oil, in a small phial, telling her that she must, on her return to her hut, pour it into the hole in which she intended concealing her money; and that if any one but herself touched the money while there, without her permission, he would not long survive. I advised her by all means to give the virtues of this charm as extensive a circulation as possible, and I had no doubt she would not be robbed again. The poor old woman could not express the gratitude she felt for my kindness; she dropped on her knees before me, thanked me in the warmest terms, and pressed me to accept of forty cowries, the only money she had then in the world. Of course I refused to deprive the old woman of her substance, and sent her away highly pleased with the treatment she had received.

16th.- - Having paid my respects to the king and his wives last evening, left Cuttup at six in the morning; and pursuing a southwest direction till half-past one, when we proceeded due south, arrived at Coogie, a small town, at half-past three in the afternoon. Owing to the bites and stings of myriads of flies, the asses, for the 
whole of the journey, were restive and unmanageable, frequently throwing off their loads, and detaining us on the way by their wanton pranks. The roads were of the very worst description; at one moment obliged to carry the loads ourselves over dangerous precipices, and at the next up to our waist in mud and water on the low grounds. Two Fellatas came to see me this day, but made no observations.

17th.-Pursuing our journey at half-past five in the morning, arrived at a town called Dungoora at two in the afternoon. It rained heavily during this day's journey, and consequently got wet to the skin on halting. The water rushed in torrents through the valleys, and in some places on the hills the beasts sank to their knees in mud and dirt. Crossed a large river to-day, named Rary, flowing to the south-east, our course being to the south-southwest. 'The country traversed is hilly and thickly wooded; the soil rich and fertile. Not being able to obtain provisions, and every article being wet through, obliged to remain in our wet clothes all night, without fire or food.

18th.-At 6 A. M. proceeded on our journey, and arrived at Dumrora at 6 P. M. Our route, some parts of the day, lay over steep and craggy precipices, some of them being of a most awful height. On the summit of one of these places the path was barely wide enough for a single beast to pass. The horse that carried the portmanteaus, in which were the journal, papers, watches, \&c. struck himself against a piece of rock projecting over the road, and was precipitated a distance of eighty yards, the ropes which were bound round the portmanteaus arresting his further progress. I was horror-struck on observing the poor little animal tumbling head over heels down the frightful declivity, and was much afraid he would be dashed to pieces, the portmanteaus broken, and their contents destroyed; but was most happy to see him entangled in some stunted trees which fortunately grew on the side of the pre- 
cipice, which is seven hundred yards in height. This accident occasioned us two hours' delay; but the horse was not materially hurt. We had been travelling about half an hour after leaving this spot, when we came to a place from which there was an extensive and beautiful prospect of the surrounding country; and eight days' journey might plainly be seen before us. I halted for a moment to gaze upon the fine and noble scene around me. About half a day's journey to the east stood a lofty hill, at the foot of which lay the large city of Jacoba. Mahomet affirmed that there is a river called Shar, or Sharry, about half a mile from that place, which derives its source from the lake Tchad; and that canoes can go from the lake to the Niger at any season of the year. The Sharry empties itself into the Niger at Funda; and the Niger, after leaving the towns of Cuttum Currijee, Gattoo, and Jibboo, joins the salt water, but at what particular place Mahomet could not rightly inform me, never having heard the word "Benin" mentioned before. Funda lies due west of Dunrora. Not being aware that the chief of Dunrora was so very great a man, I this day sent him only a pair of scissors and fifty needles, which were shortly afterwards returned to me with a request that I would give them to a less exalted personage. On asking the reason of this conduct, the people informed me I had insulted the dignity of their chief by offering so trifling a present, he being a mighty man. Not feeling disposed, however, to add any thing else to it, I sent back the messenger empty-handed. Dunrora contains 4000 inhabitants.

FROM DUNRORA BACK TO ZEGZEG.

19th.-This morning as I was loading my beasts, and preparing to depart, I perceived four armed men ride up at full gallop to the Q Q 
residence of the chief, their horses covered with foam and perspiration. The chief had no sooner been made acquainted with their errand than he came to me, followed by an immense multitude of people, and gave me to understand that I must immediately return with the messengers, who had just arrived, to the king of Zegzeg, who much wished to see me. I remonstrated with lim on the injustice of the command, telling him it was a hard case I should go back to Zegzeg, having proceeded so far on my way unmolested: his only reply was, that if he suffered me to depart he should lose his head. Finding entreaty and persuasion useless, I consented, with a bad grace, to return with the messengers. 'Thus, after seventeen days' perilous travelling from Kano, with a fair prospect of reaching Funda in twelve or thirteen more, from whence four days' sail would bring me to the salt water, a new country opening before me, and filled with the most lively anticipations of solving the geographical problem which had for so long a time puzzled Europeans, of ascertaining whether the Niger actually joins the sea in that direction, was I obliged to abandon my fondest and long cherished hopes, and return to 'Zegzeg; from thence to be transported the Lord knew whither. I felt depressed and unhappy at this sudden turn in my affairs, and cared not much whether I lived or died. We left the town in the course of the day, and entered Cuttup by the same route I had taken on the 21 st.

I was attacked with dysentery on my arrival, and remained at Cuttup four days, much against the inclination of my guards; suffering during that period, and indeed for several days after, more dreadfully than I can describe.

25th.-Left Cuttup by another route at eight in the morning, accompanied by two messengers on foot, in lieu of the horsemen, who, on finding me very tractable, and too ill to make the least exertion, had thought them strong enough to guard me. After 
proceeding in a northerly direction till twelve, reached an insignificant village, forming part of Cuttup. The country traversed level, but thickly wooded, and fertile.

26th.-Arose at 6 A. M., and did not halt till ten at night, when we fixed our tent on a clear space in the midst of a large wood; vast quantities of bamboo, palm, and cocoa-nut trees growing in every direction. 'The asses were very troublesome to-day, having been annoyed by the forest flies; myriads of which swarm in the woods, and alight in great numbers on men and animals. These insects bit the asses so severely that the blood streamed copiously from their sides and legs, and made them so restive that they frequently flung off their loads, and rolled themselves on the ground. Being unable to procure any better provisions, we contented ourselves with a little boiled corn. Although still very ill, found myself greatly improved.

27th.-At seven in the morning proceeded, and after a fatiguing journey, reached a Bowchee village, named Cokalo, at 2 P.M. The inhabitants being very poor, could procure nothing but corn. 'The chief of the village had made a fetish, and having roasted a dog, stewed a large snake in oil and water, and boiled a good deal of corn, invited his people to a feast, of which they partook freely. A small bowl of boiled corn, enriched witl a portion of the reptile, and the liquid in which it had been dressed, was sent me from the chief's table. Supposing it to be fish on the boiled corn, I ate a mouthful or two, but there being a peculiar, and not disagreeable flavour with it, I cursorily asked a person, who stood by my side, what kind of fish I was eating; but on his telling me it was part of the snake, I could eat no more. Pascoe, however, was not quite so fastidious, and consumed the remainder with great relisl, declaring that, in his opinion, it was much superior to dried ling.

28th. - Proceeding this morning at eight, arrived an hour after on the banks of the Coodoonia; but here it was broader, deeper, 
and more rapid than at Cuttup. In attempting to convey, on a small bamboo raft, one of my portmanteaus to the opposite side, found it would not bear its weight, and snatched it from the raft just in time to save it from sinking. Finding it, therefore, dangerous to cross, till the river became more shallow, I strenuously refused to accede to the wishes of the messengers, who strongly urged the necessity of my reaching Zegzeg as quickly as possible; observing, that I would neither risk my property nor person on so weak and dangerous a conveyance. 'They abused me in the most insolent terms, and threatened to go immediately and inform their king of my refusal to proceed. I desired them to give my best respects to his Zegzeg majesty, and told them they were at liberty to go as soon as they pleased. They left me in great anger, cursing me as they went; whilst I slowly proceeded with my horses and asses to the village we had left in the morning.

Whether the messengers did or did not go to Zegzeg I cannot tell, but they did not return till the 11 th July following. I remained all that time in the village, very ill, with nothing to eat but boiled corn, not by any means relishing their roasted dogs. The inhabitants, who came by hundreds each day to visit me, were destitute of apparel of any kind, but, nevertheless, behaved in a modest and becoming manner. 'The men did not appear to have any occupation or employment whatever, and spent their time in loitering about the village. The women were generally engaged most of the day in manufacturing an oil from a small black seed and the guinea nut.:

July 11 th. - - The messengers being returned, came to me, and, in a very submissive tone, requested me to accompany them, as the king did not think it proper to permit me to go any where until I had first seen him. Accordingly I loaded my beasts, and followed them a second time to the river, but found it still much too deep to walk through; and one bamboo raft being too small to bear a 
heavy article, I caused two to be lashed together, which answered the purpose extremely well. The portmanteaus, \&c. were first taken over; and I, laying myself flat on my face, was next ferried across by the two messengers, who swam behind, and dexterously propelled it forward with their hands. The horses and asses were not quite so fortunate; the current being strong and rapid, they were borne by it nearly a quarter of a mile from the place at which they entered the water. Every thing being at length safely landed on the opposite side, at $11 \mathrm{P}$. M. left the banks of the river, and pursuing a north-east course till sunset, pitched our tent on a rising ground near a small stream. The asses have been again troublesome the whole of the way.

12th.-Leaving at half-past six in the morning, pitched our tent outside a small walled town called Accoran, the first I had seen since leaving Nammaleek, at two in the afternoon. The west end of the town is defended by an immense naked rock, and the other parts by a mud wall and a deep ditch. It is inhabited by Bowchee people, miserably poor, who could not sell us even a single goat or fowl. A thunder-storm came on this afternoon, with its usual violence, accompanied with vivid lightning and floods of rain, which continued the whole of the night.

13th. - Started at eight in the morning, and reached Cowroo at thrce in the afternoon. The country traversed differed but little from that previously mentioned. The palm and cocoa-nut trees, however, which had been so plentiful since leaving Cuttup, suddenly disappeared, and I saw no more of them till our arrival near the sea-coast in Yariba. Crossed several streams in the day, and numerous steep and craggy but low mountains lay on our left and right, on the very summits of which small villages are built; the roads leading to them must be extremely dangerous. Remained here three days, in order to refresh my men and beasts. 'The chief' is a fine looking man, and was very neatly dressed in a plain white 
tobe and trousers, his feet bare, and stained red. I gave him an old piece of carpeting, a scarlet cap, white turban, and a gilt chain, in return for abundance of excellent provisions, \&c. The inhabitants of the town are principally Houssa people.

17th. - Started at seven in the morning, and keeping a north-east course, reached a large river called Makammee, rumning southerly, which derives its name from a town at a short distance. Were ferried across in a canoe, which cost one hundred needles and sixty cowries. On landing on the opposite side, suddenly altered our route to due east, and arrived at the town of Makammee, at two in the afternoon. Sent the chief a paper of unwrought silk, fifty needles, and a pair of scissors, which he was very grateful for, and returned me two fish, weighing seven or eight pounds each, and plenty of other provisions.

18th. - At six in the morning proceeded, and travelling north by east till twelve at noon, halted at Wautorah, another walled town. The chief sent me some tuah and corn; but there being no poultry to be had, shot a few pigeons, which surprised and terrified the inhabitants to an alarming degree. Gave the chief a pair of scissors and a hundred needles.

19th.-_This morning, it being damp and foggy, Mahomet and the two messengers refused to proceed, and told me I might go alone, thinking to detain me in the town till it would be too late to leave this day; but ordering Pascoe and his wife to assist me, loaded the beasts, and went on without them. Unfortunately the path leading to some gardens belonging to the inhabitants of Wautorah misled me. I had gone some distance when, discovering my mistake, instead of returning to the beaten track the way I came, crossed the country in order to save time; but owing to the marshy nature of the ground, and the swamps, which were numerous, did not get into the proper path till four in the afternoon; when, after travelling two hours on it, the beast became fatigued and exhausted, 
in consequence of which fixed the tent by the road-side; and being much distressed for water, luckily slaked my thirst from some which, oozing from the fissures of a neighbouring rock, I was enabled to obtain in small quantities.

20th.-At six in the morning proceeded on the path, and crossing a large river running to the south at one, entered a spacious town named Eggebee at two in the afternoon; the chief of which is one of the king of Zegzeg's principal fighting men. Eggebee is an extremely neat as well as large town, surrounded with a high wall, and situated in the centre of a fine and highly-cultivated plain. Nothing can be more beautiful than the appearance of the country for miles round. Lofty trees, covered with the most beautiful foliage, casting their welcome shade along the earth; plots of ground, planted with corn, every here and there enriching the landscape, and vegetation springing up at every step in the richest luxuriance, afforded a gratifying and delightful relief to the sameness of African scenery, which is welcomed with emotions of pleasure that a person who has never wandered in these regions can never know. The town contains six or seven thousand inhabitants, who are all dressed with peculiar neatness; while the cleanliness they display, both in their huts and persons, strongly reminded me of my own far-distant country.

21st.-Left Eggebee at six in the morning, and travelling till two in the afternoon, were obliged to fix our tent in the midst of a wood, the asses being completely exhausted. No village being near, could obtain no provisions. Our course this day was northerly. 22d.-Started at five in the morning, and entered Zegzeg at twelve at noon. The country the whole of the way from the "bush" is rich and fertile, principally laid out in gardens. The king of Zegzeg did not see me this day, but ordered me to lodge at the house of Abbel Crême, in which my late master and myself 
stopped on our way to Kano. In the evening plenty of provisions were sent by the king.

23d.- Visited the king this morning, taking with me four yards of blue, and the same quantity of scarlet damask; four yards of blue and scarlet silk, a gilt chain, six prints, among which is one of his majesty, and another of the duke of York, two pair of scissors, a quire of paper, a scarlet cap, six yards of white muslin, and a blank drawing book. This present pleased him highly; and not long after my return to my lodgings, he sent me two fine bullocks. The chief subsequently told me that the reason for his ordering me to be brought back to Zegzeg was on account of the war between Sultan Bello and the king of Funda, who would murder me as soon as he had me in his power, for having taken presents to his powerful enemy: it was therefore doing me a great act of favour. Abbel Crême, my host, thought it necessary for me to give something to the king's eldest son : I accordingly presented him, shortly afterwards, with two yards of blue and scarlet damask, an unwritten journal-book, half a canister of powder, a quire of paper, and a gilt chain. 'The prince is a remarkably fine and handsome young man, about twenty-two years of age, and was particularly kind to me. As an especial mark of favour, he took me into his inner apartments to see his wives, fifty in number, who, on my entrance, were all sitting in the shade outside their huts, and industriously occupied in preparing cotton, making thread, and weaving it into cloth. The prince said, "I have brought the Christian to see you." They no sooner looked up than they all instantly dropped their work, and ran, or rather flew, into their coozies, and I saw no more of them. Four of these ladies reside together in one coozic. In the course of the day the prince offered me a young female slave, named Aboudah, for a wife! I accepted of her with gratitude, as I knew she would be serviceable to me on my journey, 
and I should also have the satisfaction of giving her her freedom on arriving at the sea-coast. Mahomet came to me to-day, having just returned from Wantorah; but he had used me so ill that I immediately discharged him. I had seen enough to convince me that no dependence could be placed on the fidelity of hired domestics; I therefore purchased a young slave named Jowdie for seven dollars, to supply Mahomet's place. The asses being nearly worn out with our long and fatiguing journey, and wanting at least twenty days to recruit their strength, I thought it better to exchange them for a strong Yariba pony that remained in Zegzeg for so long a time. 'This pony, with the pack bullock the king had given me, were fully equal to supply the place of the asses. Presented Abbel Crême with an unwrought journal-book, a turban, and a scarlet cloth cap. Both the king and his son were at the wars when we passed through their territories on our way to Kano; and it was in order to gratify their curiosity, I verily believe, that I was so unfortunately stopped on my journey to Funda. Asked and obtained permission of the king to proceed to-morrow.

FROM ZEGZEG TO BADAGRY.

24th.-Left at 6 A. M., and halted at Wauree at 3 P. M., fixing: the tent within the walls.

25th.-Arose at the same hour, and entered Fatica at four in the afternoon. 'The king of Zegzeg had sent a messenger to the chief of this town, desiring him to provide us with an escort to conduct us through a wood which was infested with robbers.

26th.-Rested at Fatica to-day, the chief supplying us with abundance of provisions, \&c. Gave him two yards of scarlet silk, a cloth cap of the same colour, two pair of scissors, and a hundred needles. 
27th.-Left at eight o'clock in the morning, escorted by eight armed men on horseback and four on foot, passed unmolested through the wood, and pitched our tent near Kazigee, at 7 P. M. Giving the men fifty needles each for their trouble, I ordered then to return to Fatica. We had now left the Houssa country, and entered Guarie.

28th.-Previous to leaving Kazigee, a tax of 600 cowries, or a present was demanded, before we could go on : preferred paying the money; and, travelling till three in the afternoon, halted near Maccondie, a small walled town. Here I fell in with a gaffle of merchants on their way to Coulfo. Purchased a small goat of them for 1800 cowries.

29th. - Left the town at six in the morning, and at twelve at noon fixed our tent outside the walls of the city of Guarie, the king of which sent me a quantity of stewed beef, a calabash of honey, and milk and tuah.

30th.- Unable to cross the river to-day.

31st. - Waited on the king this morning, and gave him three yards of light blue damask, the same quantity of blue and scarlet silk, an unwritten journal-book, and a red cap. To one of the chief men a red cap and a hundred needles. The old king asked the reason of my having been so long on the road from Kano, as merchants had told him I had left a great while ago. I answered I had attempted the route to Funda, it being much nearer to my country than any other. He observed, in reply, that if I wished to go that way then, he would send a messenger with me, and had no doubt of my reaching Funda in safety, the king of that place being his particular friend. I expressed much regret at not being able to embrace his kind offer, telling him my presents were nearly exhausted, and I had nothing good enough to give the king: on this account I felt no inclination to pass through his dominions. The king of Guarie had a eunuch in his service who was born not far 
from Funda. This man, at the instigation of his sovereign, came to see me, and I had a long conversation with him, in the course of which he stated his native place was Gibboo, on the banks of the Niger, four or five days' journey from Funda. He was given as a slave to the king of the latter place, who had sent him to his present master. He had gone by water from Gibboo to Funda in eight days, the river running five knots an hour against him. The voyage from Funda to Gibboo might easily be done in three or at most four days. Fell in with a party of merchants in the town today, so far on their journey to Coulfo, who begged me to accompany them, observing that the road to that place was rendered dangerous by banditti, who had lately committed many excesses. Fearing there might be some truth in these reports, I waited for them three days; but not having then paid the accustomed duty, and not seeming to have the least inclination to depart, I preferred risking the dangers of the route to remaining any longer in Guarie.

August 2d.-Paid niy respects to the king this evening, who wished me to take a messenger as far as Womba; but declined his generous offer, observing I was not afraid to proceed with my own small party, and would not put him to any trouble or inconvenience.

3d.-At half-past five in the morning left Guarie, and reached Fullindushie at two in the afternoon.

4th.-Heavy rain the whole of the day, which disabled us from taking down the tent.

5th.-Leaving Fullindushie at six in the morning, pitched our tent outside the walled town of Kazzagebubba at four in the afternoon. The chief sent tuah and corn to us; but not being marketday, apologized for having nothing better. A red cap and a pair of scissors made him quite proud.

6th._-Started at the same hour as yesterday, and crossing a large river in a canoe at three in the afternoon, pitched our tent in the 
midst of about fifty small uninhabited grass huts, erected by a party of merchants, as a temporary abode, some months before. In the night, the mosquitoes were so numerous and troublesome that we were obliged to set fire to the huts to drive them away.

7th.- Took down our tent at six in the morning, and travelling till six in the evening, arrived at Womba, a large town, surrounded by a high wall. The chief sent us fowls, rice, milk, and a bowl of honey, with corn, \&c. for the horses. Being in want of money, sent needles to the market to sell, which fetched fifteen cowries each, and brought me in the whole 3,400 cowries. Presented the chief with two yards of scarlet and blue silk, a scarlet cap, and a pair of scissors.

8th. - This day paid my respects to the king, who insisted on sending a messenger with me, declaring the roads to be dangerous and unsafe without a guide.

9th.-At six in the morning left Womba, accompanied by the messenger; and at six in the evening, crossing a large river, halted on the south side, and fixed our tent amidst a number of grass huts, similar to those mentioned on the sixth. In the night burnt them to the ground, in order to destroy the mosquitoes and vermin, which annoyed us exceedingly.

10th.--Started at the same hour as yesterday, and halted in the town of Beari at 2 P. M. Instead of journeying in a southwest direction to Youri, took another road, and kept due south, having been informed that a party of merchants had been plundered, and many of them murdered, on the road I intended taking. 'The chief sent me a sheep, a Muscovy duck, a quantity of yams, and some beer made from Indian corn. Returned him one yard of scarlet and blue silk, a scarlet cap, and four prints, "which much delighted him. As soon as one of the head men was aware of my approach to the king's residence, he blew a shrill and loud blast through a long brass trumpet, the noise of which brought all the principal male inhabitants to the spot, who entered the hut, and 
seated themselves in a circle round their sovereign and myself. The chief is a fine looking man, apparently about fifty years of age, with a noble expression of countenance, and a commanding air. The coozie into which I was introduced is the largest I had ever seen in Africa, being not less, I should think, than eighty yards in circumference. A man stood by the side of the chief while I remained, who repeated to him what I had to say, and the answers were returned to me by the same individual: this singular custom is, I believe, peculiar to Beari, as I never observed it in any other town in Africa. The chief asked the usual questions about my king and country. The town is surrounded by a high wall and a deep ditch, and contains about four thousand inhabitants, some of whom had seen us before at Womba.

11 th.-At six in the morning continued our journey, and arrived at Ragada at two in the afternoon. Remained outside the walls, in order that the horses might feed on the rich grass which grew in abundance on the spot. The chief wished me to lodge with him in the town; but, for the reason above stated, did not accept his invitation. 'The walls of the town are about three miles in circumference.

12th.-In passing through the town this morning, at 6 A. M., waited on the chief, who was delighted to see me, and gave me a sheep, some fowls, and a jar of gear (a beer made from Indian corn), and offered me a messenger, which I declined. Journeyed onwards without halting, till we pitched our tent a little to the west of Wittesa, at three in the afternoon. It began to rain about an hour after leaving Ragada, and continued with great violence till after sunset. Although the portmanteaus were defended by a thick bullock's hide, every thing in them, with the exception of the papers, became completely soaked. Here I met with a party of merchants going to Koulfa.

13th.-Remained here to-day to dry our tent, clothes, \&c. Boussa 
Jack, the horse which was presented to my late master by the king of Boussa, became dangerously ill. I bled him profusely, and in the evening he was much revived. Sold an unwritten jourual-book and a few needles for 2000 cowries.

A man from the town in a state of intoxication came to my tent this evening, with a calabash of bum, and insisted, in an insolent tone, that I should come out and drink with lim. Being busily engaged in packing up the articles that had been put out to dry, I did not choose to oblige lim so far. When lie found I had no inclination to leave the tent, he said he was determined to come in. Wishing to intimidate the fellow, I took a loaded pistol, and went to him, threatening to shoot him unless he immediately left the place; but this, instead of laving the desired effect, only exasperated him the more; and flourishing a long spear he had with him over his liead, as quick as lightning he made a desperate thrust at me. Slipping a little on one side, I caught the weapon in my hands, within an inch of my breast, which saved my life. I was highly incensed at this violent act, and told the people who stood by, and were spectators of the whole affair, that if they did not that moment take him from the tent, I would shoot him in earnest: half a dozen of them accordingly dragged him away. Next morning the fellow returned, and throwing himself at my feet, begged I would not inform Sultan Magie of his conduct; for if it came to his ears he would lose his head. I forgave him, on condition that he should never get tipsy again.

14th.-Struck our tent at six in the morning, and passing through the ruins of a large town called Kabojie at twelve at noon, reached Dogo at three in the afternoon; but stopping only to pay the accustomed duty, halted a little to the westward of it. In the evening several respectable females of the town came to the tent, with tuah and stewed beef, for which I gave them a few beads. 15th.-At seven in the morning proceeded on our route, and 
arrived at Coulfo at two in the afternoon. I was met at the gates by the female in whose house we lodged on our way to Kano, accompanied by the most respectable of her sex in the town. 'They expressed the most lively joy at seeing me; but when I told them that my father was dead, they were deeply affected, and made loud lamentations. Although the town was full of merchants, and her own house occupied with some of them, this kind old woman turned out her lodgers, and gave me the best apartment in it. 'These merchants came from Cuttum Kora, Youri, Kano, Soccatoo, Borgou, and Yariba, to purchase Nyffé cloth, which is the best in central Africa, iron bits and stirrups, brass ornaments for saddles and bridles, and brass ear and common rings: this traffic is carried on to a considerable extent. The good old chief sent me fowls, tuah, milk, and bum: my hostess gave me a sheep; and during my stay, this excellent old lady sent me provisions daily.

Remained at Coulfo five days, and finding my Yariba pony, and the bullock the king of Zegzeg had given me, unfit to bear the fatigues of a journey to the sea-coast, exchanged the bullock and an old 'Turkish jacket for a couple of asses; but could not dispose of the pony, although I offered to sell him for a dollar. The morning before my departure found poor little Boussa Jack dead outside my hut. It was with the utmost reluctance ny hostess would part with me; and I left her with a promise of returning in two years. She gave me an order to purchase looking-glasses, \&c. for her on my arrival in England, which I was to bring with ne; all which I promised to do. Gave her a dollar to make a ring, and half a yard of scarlet damask. I took to the old chief a scarlet cap and one of my late master's turbans, and begged he would not compel me to visit Sultan Magie at Sanson, as I had nothing to give him. He replied, if I did not wish to visit the sultan, to leave as soon as possible, or he might send messengers for me. Sold 5000 cowries worth of needles to assist me on my journey. 
20th.-Having paid my respects to the king last evening, left Coulfo, in high spirits and good health, at six in the morning, and halted outside Makonja at five in the afternoon. Here I found a party of merchants going to Gonja, near Ashantee, for gora nuts. Unable to procure any kind of provisions in the town, I took my gun and shot a heron; not being aware that this, being a fetish bird, is allowed to be eaten only by the chiefs. On being made acquainted with the circumstance, one of the principal inhabitants came with a loaded gun, and threatened to shoot me, making use of the most abusive language. I dared him to fire, and said I should complain to Sultan Magie of his conduct.

21st. - Early this morning, the person who had threatened to shoot me yesterday came to beg my pardon, excusing his conduct on the plea of being intoxicated with drinking too much bum. At six in the morning continued our route, and at twelve at noon halted at Dalho, on the banks of the river Quontakora. At 3 P. M. every thing was safely landed on the opposite side; and journeying till sunset, reached the foot of a hill five miles to the east of the Niger, and rested there for the night. The country traversed to-day was one continued swamp, the mud and water frequently reaching up to the asses' side. Rained continually throughout the day.

22d.-At nine in the morning left the hill, and at eleven at noon came to the liver Niger, which was full one hundred yards wider than we found it on our way to Soccatoo. After waiting an hour, a canoe came to fetch us; but we did not get over till two in the afternoon, the horses, \&c. being obliged, by reason of the rapidity of the current, to be ferried across in the canoe. My poor slave Jowdie, never having in all his life seen so large a body of water before, became greatly agitated, and was afraid to cross. Getting him at length, after much persuasion, into the canoe, he reached the other side, but fainted the moment he put his foot on 
terra firma. We landed at Inguazhilligee, where the principal inhabitants pressed us to remain ; but having no presents to offer, declined stopping. Expecting to reach a village in the evening, made all possible haste to get out of the town; but at six o'clock, P. M. the asses being quite spent, were obliged to fix our tent on a marshy spot in the midst of a bush. The roads were horribly bad, through swampy ground, and could only travel two miles an hour. This evening, as well as the two former ones, went to rest without food.

23rd.-At six in the morning, proceeding on similar roads, and having heavy rain, reached a small village at one, and were obliged to remain there for the day to give the asses a little rest. The poor animals had stuck in bogs seven times in the morning, each of which times the loads were taken from their backs, and they themselves dragged with much difficulty and loss of time out of their unpleasant situation. None of the poor inhabitants of the village understanding the Houssa language, I entered a hut, the door of which was open, and giving the inmates a few beads, made signs with my hands that we stood in need of provisions and rest. One small lean fowl, however, was all that could be procured from them; but having the good fortune to shoot a guinea-fowl, made a tolerable meal, and slept soundly.

24th.-At seven in the morning left the village, and journeying till 3 P. M., halted at the pleasant town of Wowow, one of the handsomest, if not the handsomest, in the interior of Africa. It had taken us two days and a half on the road from Inguazhilligee, while in the dry season we did it with ease in one.

25th.-Took the old king a present, consisting of four yards of scarlet and four yards of blue damask, four yards of scarlet silk, a cap of the same colour, and a white turban. Though overjoyed to see me at first, he was much distressed on mentioning the death of 
Captain Clapperton at Soccatoo. He wondered at my being alive, after visiting the Fellata country, the inhabitants of which he described as the most barbarous in the world; said my preservation was miraculous, and that I was certainly one of God's favourites. I was obliged to comply with his request, which was tantamount to a command, to remain with him a few days to clean seven muskets and three pistols, which he afterwards told me belonged to the white men who were drowned at Boussa. They have the Tower mark on them.

26th.-Solicited and obtained permission to visit Boussa, to pay my respects to its king.

27th.-At five in the morning, accompanied by Pascoe, proceeded on the road to Boussa; but, after journeying till six in the evening, had only got half way. The country is full of bogs and swamps, which in some places took the lorses up to their saddles in mud and wet; and Pascoe being the worst rider I ever saw, was soused in them more than a hundred times. The remaining part of the road appearing still more difficult and dangerous, found it impossible to proceed any further.

28th.-Returned to Wowow.

29th.-C'The king sent me a goat, cut up into small pieces, and a large bowl of tuah, to make a sadacco for my poor master; a ceremony common in many places in the interior, on the decease of any person of consequence. The pieces of goat and the bowl of tuah are sent to the mallam or priest, who repeats a short prayer over them : it is however necessary, before this can be performed, to place a gold or silver coin, or at least an article made of either of those metals, on the top of the bowl. Having no coin I could part with, I put a silver pencil-case in its stead, which was never returned me. After the prayer has been pronounced over the tuah and goat's flesh, they are sent back to the person to whom they belong; and 
any one who is disposed comes and eats ; each person, before tasting, repeating this pious ejaculation, "God send him safe to heaven!" 'The goat's flesh and tuah sent to me were soon consumed.

30th.-Having finished cleaning the muskets and pistols, asked the chief permission to leave Wowow. The old man, smiling, told me not half my business was done; he wanted six charms, which I alone could write. 'These charms were to be worn on his person, and to possess the following virtues: 1st charm. If his enemies thought of making war on him, it would cause them to forget to put it in practice. 2d. If they should be on their way to his city, for the purpose of warring, it would turn them back. 3d. If they should discharge their arrows at his people, when close to the city walls, it would cause them to rebound in their own faces, and wound them. 4th. It was the province of this charm to prevent his guns from bursting. 5th, was to preserve the person who might hold the gun from receiving any injury, should it unfortunately explode. 'The 6th and last charm was to make him the happiest and most successful of men.

31st.-Carried the charms to the king, on which I had written scraps of old English ballads, which made him in the best humour in the world.

September 1st.--The king still wished to detain me longer, and insisted on my selling or giving him my gun and pistols, the only arms I had left. I endeavoured to soften him by every means in my power; but finding him firm in lis determination of having the gun, and at least one of the pistols, and knowing resistance would be ridiculous, I sent them to him, leaving it entirely to his generosity to give what he thought proper. The liberal-minded chief shortly afterwards returned 4,000 cowries (worth little more than a dollar), as a sufficient remuneration for the gun and pistol, but made me a present the next day of a beautiful little mare.

3d.-Early in the morning the old chief desired to see me before 
I left, and obtained from me a promise to return to him after having visited my own country. He showed me various patterns of silk for a tobe I was to bring from England for him; and said, as I was going out of the apartment, "Your countrymen may come here, and build a town, and trade up and down the Niger: we know now that they are good men, but we did not think so when the white men who were drowned at Boussa were in the country." He kept me with him till nine o'clock in the morning, when, on going to my hut, I found a party of merchants waiting for me, whom the kind old chief had detained on purpose that they might accompany me to Khiama (which had been concealed from me entirely), the roads to that city being infested with bands of robbers. Crossed the river Auli at twelve at noon. The current being very rapid, we had extreme difficulty in getting over; but no accident occurred, and we fixed our tent on the south bank of the river. In the evening the mallam, or priest of the merchants, came to my tent, and gave me the following account of Mungo Park and his unfortunate companions :

"You are not, Christian, the first white man I have seen. I knew three of your countrymen very well. They arrived at Youri at the fast of the Rhamadan (April). I went with two of them three times to the sultan. The person that appeared to be the head of the party made the sultan a valuable present on one of his visits, which consisted of a handsome gun, a cutlass, a large piece of scarlet cloth, a great quantity of beads, several knives, and a looking-glass. He was a very tall and powerful man, with long arms and large hands, on which he wore leather gloves reaching above the elbows. Wore a white straw hat, long coat, full white trousers, and red leather boots. Had black hair and eyes, with a bushy beard and mustachios of the same colour. The sultan of Youri advised your countrymen to proceed the remainder of the way on land, as the passage by water was rendered dangerous by numerous sunken rocks 
in the Niger, and a cruel race of people inhabiting the towns on its banks. 'They refused, however, to accede to this, observing that they were bound to proceed down the Niger to the Salt Water." The old mallam further observed that, "as soon as the sultan of Youri heard of their death, he was much affected; but it was out of his power to punish the people who had driven them into the water. A pestilence reaching Boussa at the time, swept off the king and most of the inhabitants, particularly those who were concerned in the transaction. The remainder, fancying it was a judgment of the white man's God, placed every thing belonging to the Christians in a hut, and set it on fire." It is not a little remarkable that it is now a common saying, all through the interior of Africa, "Do not hurt a Christian, for if you do, you will die like the people of Boussa." 'The old man left me shortly afterwards ; and I thanked him for his information thus voluntarily given.

4th. - At nine in the morning left the bank of the river, and at two in the afternoon fixed our tent in a bush. Proceeded this day by ourselves, the merchants not being ready to start in time. Notwithstanding the account the king of Wowow had given me of the dangers of the road, we were not molested in our journey.

5th.-At six in the morning were again in motion, and halted at four in the afternoon in a small town called Gorkie. This day one of the asses was taken suddenly ill on the road, and it was with the utmost difficulty we could drag him to the halting place. 'The chief of the town, at the instigation of the king of Wowow, supplied us abundantly with fowls, rice, yams, \&c. Gave him a pair of scissors and a few needles.

6th.-Finding the ass that was taken ill yesterday unable to proceed any farther, was obliged to leave him behind. On seeing his companion going away, the poor animal brayed most piteously, and made many ineffectual attempts to rise. At six in the morning left the town, and after sunset came to a number of grass huts, 
similar to those mentioned before; in the largest of which we rested for the night, and did not fix the tent. On crossing a river, apparently very narrow, to-day, my horse unexpectedly sunk several feet in mud and sand, and his legs becoming entangled in the roots of some trees lying at the bottom, fell on his side, and plunging violently, threw me off his back; but not being able to get one of my feet from the stirrup, lay several seconds under water, in a most perilous and distressed state. Freeing myself at length from the stirrup, I got out much exhausted, and succeeded in extricating the horse also from his no less unpleasant situation. Some merchants told me afterwards at Khiama, that I might think myself highly fortunate in escaping so easily, the river being filled with large crocodiles.

7th. - Started at six in the morning, and arrived at Yaro after sunset. The chief made us the usual presents of provisions, \&c. A dreadful hurricane came on about nine o'clock in the evening, which lasted three hours, when it became awfully still and calm. The storm was unusually violent, and tore up large trees by the roots; the peals of thunder were fearfully loud, and shook the ground on which our tent was fixed; while large masses of fire, falling from the heavens, added not a little to this scene of devastation and terror.

8th.- Heavy rain all day; unable to proceed.

9th.-At half-past six in the morning continued our journey, and at noon entered the city of Khiama. Went immediately to the king's residence, who, as soon as he saw me, asked how I dared to come into his town without having previously sent him a messenger to inform him of my approach. I answered I had sent one of his own men, three or four days before, to acquaint him of it. "That is of no consequence," he continued; "you should have sent another this morning. Get on horseback directly, and return an hour and a half's journey the way you came: on arriving there, 
send me a messenger, and I will order a sufficient escort to conduct you into the city, in a manner deserving your rank and respectability." I was in the act of obeying this odd mandate, when he bawled after me: "I forgive you this time, Christian; but never be so remiss again." 'The chief is an eccentric but friendly kind of man, and regretted very much my father's death, which had been told him some days before by a merchant. He had heard the Fellatas had behaved very roughly to us, and had robbed us; but asked what business we had at Soccatoo? I told him we were at Kano, on our road to Bornou, when Sultan Bello sent for us, and we were obliged in consequence to visit him. He offered to send me safely to Bornou, and said he was tributary to the sheik. I replied, that Bello had taken the presents intended for him, and that I had none left worthy so great a prince, therefore could not accept his kind offer. My present to the chief consisted of a silk sword-sash, three yards of scarlet and blue damask, the same quantity of blue silk, a red cap, two pairs of scissors, and a hundred needles. I likewise gave him my old tent, which was full of holes, and quite useless.

Remained at Khiama five days, during which time the queen's treatment was kind and generous, supplying us every day with excellent provisions in great abundance. The day before my departure the king gave me a strong pony; and observed that, " if my king wished, at any future period, to send any one to Bornou, he would conduct him there by a safe route, without the necessity of going through the Fellata country. 'The king of Khiama is, without exception, the finest and handsomest man we had seen in Africa (far superior to Bello); and, with the exception of the king of Yariba, was most respectably dressed.

14th.-At six in the morning left Khiama, and halted in Subia at one at noon. 'The country traversed is full of bogs, which caused the horses to fall repeatedly with their riders. The chief of this 
town gave me a goat and some yams, by command of the king of Khiama's messenger.

15th.--Started at six in the morning, and travelled the whole of the day, till ten at night, when we rested in a bush.

16th.-Crossing a creek at 6 A. M. arrived at Mossa, a town situated on the banks of a river of the same name, which divides Yariba from Borgoo. The river was overflown, and the current strong and rapid; in consequence of which the people of the town were afraid to ferry us over. No food of any kind this day.

17th.-Asked the king of Khiama's messenger why he was so much afraid of crossing the water, observing that I had myself swam across many larger and more rapid rivers; and among other's mentioned the Niger. The man, in great trepidation, begged me, as I valued my life, not to mention the names of rivers in the hearing of the Mossa, who was a female river, and had many rivals in the affections of the Niger, who was her husband. She had a capricious, jealous, and cruel disposition; and if I ventured to place myself in her power, she would certainly swallow me up, as I had spoken slightingly of her. She was continually quarrelling with her husband, thinking he was too familiar with other rivers; and where they met they made the "devil's own noise" with their disputes. I roared with laughter when the man had done speaking, at the loves of the Niger, which made him very angry, and I had much to do to pacify him. Being unable to procure provisions of any kind in the village, went to the chief, and wished to know whether he intended to starve us. The old scoundrel had a garden in which he grew a quantity of yams; but he refused to sell me any, asserting that he had none for himself. I then asked leave for Pascoe to cut grass in his garden for the horses, suspecting his yams might be hid in some part of it: this he sulkily granted. In the evening Pascoe returned with a bundle of grass, concealed in which were several yams he had had the good fortune to discover. If this 
had not been the case, I really believe we should all have died of hunger.

18th.-Went again to the chief in the morning, and demanded something to eat. He solemnly declared he was himself starving, and could get nothing to eat. I then pressed him to send his canoe to the opposite side for provisions: after much intreaty he consented to do so, but first made a charm that it might not be injured in its perilous voyage. For this purpose he killed a fetish fowl, sprinkled its blood in the river, placed some of the entrails in the bow of the canoe, and in the stern put a broken egg: he then muttered several expressions I did not understand; and a man was sent over with the boat, which arrived there in safety; but in returning loaded with poultry and yams, it ran foul of a tree which unluckily lay in the middle of the stream, and sunk immediately, in consequence of which the whole cargo was lost. 'The chief informed me of the accident, and said that the river could not be crossed in safety for three or four days. Pascoe returned in the evening with more of the chief's yams and grass.

19th, 20th, and 21st. - Nothing to eat on these days but the yams Pascoe stole from the king's garden.

22d.-Attempted to cross the river at noon; but did not succeed in getting every thing on the opposite side till five in the evening. The horses and asses were borne a quarter of a mile down the stream, and had nearly perished. Halted at Wantatah, the first town in Yariba, about two hours after.

23d.-At seven in the morning pursued our journey, and at eleven entered Hogie, where we remained for the day. 'The chief gave me a pig, yams, corn, \&c. A red cap and fifty needles fully satisfied him.

24th.-Rested at Hogie to-day.

25th.-Left at six in the morning, and arrived at Katunga, the capital of Yariba, at seven in the evening. The low grounds were 
rendered almost impassable by reason of the rain, which fell in torrents. On our arrival I was put into the same house we occupied on our journey into the interior.

26th.-The king would not let me wait on him, fearing it might wet my feet; and accordingly he visited me with five hundred of his wives (out of two thousand), and the principal inhabitants of the city. The wives welcomed my return by singing a simple and plaintive air, with much pathos and feeling: their voices were sweet and nusical; and the whole had a novel and pleasing effect. Nothing could be heard but their strains, to which every one listened with the profoundest attention until the conclusion of the performance. The king expressed his sorrow for my master's death; and questioned me very minutely on the motives that induced us to go into the interior. On telling him it was to see if there was any thing worth trading for in the country, he appeared satisfied. He was richly dressed in a scarlet damask tobe, and a pair of trowsers made of country cloth, scarlet ground with a blue stripe; the former ornamented with coral beads; his legs, as far as the knee, were stained red with hennah; and on his feet he wore red leather sandals. A cap made of blue damask, thickly studded with coral beads, was on his head; and silver rings hung round his neck, arms, and legs. I offered him the horse I had purchased at Kano, a fine animal, that had carried me the whole of the way from that city: and regretted my inability to make him a more valuable present; but promised, if he permitted two messengers to accompany me to the sea-coast, I would send him something else. In the evening I received a goat and a great quantity of yams from the king.

27th.-The king having desired me to call on some of his head men, I waited on the master of the horse, and two others. The former gave me a goat and a bottle of honey. I remarked I was very poor, and could make him no return. 
30th.-I informed the king I was short of money, on which he generously sent me a duck and four thousand cowries (little more than a dollar). The eunuch, the king's head man, begged of me my remaining pistol, two dollars, and a scarlet cap, which I was necessitated to give him. He also wanted my ass to make a fetish, but this I refused to let him have. This evening I sent for the ass from a neighbouring pasture, when I found the poor animal had been shot in the side with two poisoned arrows. I have no doubt but this cruel action was performed at the instigation of the disappointed eunuch. The beast became a complete skeleton, and after languishing for six days in great agony, I desired Pascoe and Jowdie to take him to a short distance, and cut his throat. When the king heard of the circumstance, he immediately ordered the carcass to be cut into quarters, and conveyed to his house. After which he ordered the meat to be dressed, and having assembled his wives and head men, they regaled themselves on it with pectliar satisfaction. Wishing to pay for so delicious a treat, the king sent me a goat and a thousand cowries for the dead ass.

The people of Yariba are not very delicate in the choice of their food; they eat frogs, monkeys, dogs, cats, rats, mice, and various other kinds of vermin. A fat dog will always fetch a better price than a goat. Locusts and black ants, just as they are able to take wing, are a great luxury. Caterpillars also are held in very high estimation. The caterpillars are stewed, and eat with yams and tuah. Ants and locusts are fried in butter, and are said to be delicious. I could never make up my mind to taste any of these rich insects; Pascoe, however, is particularly fond of them, and calls them land-shrimps.

It is a custom in Katunga, when the king dies, for his eldest son, first wife, and all the head men of the kingdom, to drink poison over his grave, and are afterwards buried with him. None of the 
king's sons ever come to the throne. After the king's death, his successor is chosen from among the wisest persons of the country; an elderly man is generally preferred.

Remained at Katunga till the 21st of October, when the king gave me 4,000 cowries, and some trona to sell on the road. He ordered his head messengers to accompany me, with a desire they should command the chiefs of every town through which we were to pass, to contribute, according to their means, to our support.

On the 22d of October I left Katunga, and after a rapid and hasty journey, during which nothing of consequence occurred, arrived at Engwa on the 9th of November following. I found the railing which had been placed round the grave of poor captain Pearce washed away by the rains, and the piece of wood on which I had myself cut out his name, age, \&c. and the day on which he died, either taken off by the natives, or also washed away by the rains. The only means by which I recognized the spot was the appearance of the earth, on which there was no vegetation, and its having sunk five or six inches. I went to the chief, and giving him half a yard of blue damask, and a pair of scissors, entreated him to build a house over the spot, and have it thatched, promising to send him a present from England in a short time, if he did it. He promised faithfully to erect a house as soon as the rains were over.

Nov. 12th.-Arrived at Jennah this afternoon, and found the grave of Dr. Morrison to be in a perfect condition. The king had had it kept in excellent order, and was to have been rewarded by Mr. Houston, who himself died shortly afterwards at Accra. In this city the horses the kings of Wowwow and Khiama had given me, unfortunately died.

Remained two days at Jennah, when we proceeded, and on the Q1st entered Badagry; all the natives on the road from Kano 
having behaved remarkably well to us. The country traversed was swampy, and full of water the greatest part of the way, which rendered travelling tedious and unpleasant.

The king was glad to see me, gave me his own house, constructed of bamboo, whilst he himself, much against my inclination, resided in a small miserable mud hut. Like every other prince on the road, he was grieved to learn the decease of my master. I gave him my little horse, which I had brought the whole of the way from Soccatoo, and all the articles for presents that were left, consisting of two yards of light blue damask, and the same quantity of scarlet ditto, two yards of scarlet and blue silk, and two dozen pair of stockings.

On the 28th I waited on captain Morrison, a Portuguese slavemerchant, and obtained from him goods amounting to ninety-four dollars: and a barrel of gunpowder, which cost a doubloon, I paid for myself.

Three of the Portuguese slave-merchants residing at Badagry, went to the king one day, and told him and his principal men that I was a spy sent by the English government, and if suffered to leave, would soon return with an army and conquer their country. This the credulous people believed, and I was treated with coldness and distrust by the king and his subjects, who seldom came to see me. All the chief men at length assembled at the fetish hut, and having come to a resolution that I was to drink a fetish, sent for me to appear before them. On my way five or six hundred people gathered round me, and I could proceed with difficulty. A great number of them were armed with hatchets, bows and arrows, and spears; and waited outside the hut till I came out. On entering one of the men presenting me with a bowl, in which was about a quart of a liquid much resembling water, commanded me to drink it, saying, "If you come to do bad, it will kill you ; but if 
not, it cannot hurt you." There being no resource, I immediately, and without hesitation, swallowed the contents of the bowl, and walked hastily out of the hut, through the armed men, to my own lodgings, took powerful medicine and plenty of warm water, which instantly ejected the whole from my stomach, and I felt no ill effects from the fetish. It had a bitter and disagreeable taste, and I was told almost always proved fatal.

When the king and chief men found, after five days, that the fetish had not hurt me, they became extremely kind, and sent me presents of provisions, \&c. daily, and frequently said I was protected by God, and that it was out of the power of man to do me an injury.

I. remained at Badagry two months, but was advised by the king never to go out unarmed, as the Portuguese took no pains to conceal theil inveterate dislike to me; and would no doubt assassinate me the first opportunity that might present itself. Several persons in canoes passed repeatedly from Badagry to Cape Coast, but although I offered to reward them, I could never get them to take a note for me to the latter place, so active had been the exertions of the Portuguese to debar me from every means of communicating with my countrymen.

There were five factories at Badagry, in which were upwards of one thousand slaves of both sexes, chained by the neck to each other, waiting for vessels to take them away.

Captain Morris, of the brig Maria, of London, hearing of my being at Badagry, kindly came from Whydah to fetch me, and on the 20th of January I went on board, and arrived at Cape Coast on the 31 st of the same month. Here I gave my faithful slaves, Aboudah, Jowdie, and Pascoe's wife their freedom, who testified their sorrow on my departure by heaping sand on their heads, and other marks of grief peculiar to the African race. Colonel Lumley 
generously promised to give them pieces of ground and a small sum of money, and I have no doubt they will do well.

Sailed from Cape Coast in the Esk sloop of war February 9 . and arrived in England the 30th of April following. 
. 


\section{A P P E N D I X.}

\section{A LIST, OR SUMMARY ACCOUN', OF THE LATE CAP'TAIN CLAPPERTON'S ARABIC PAPERS, TRANSLATED BY MR. A. V. SALAMÉ.}

1. A geographical description of the course of the river Cówara, the road from Soccatoo to Maséna, from Timbuctoo to Soccatoo, and the countries thereabouts, with their inhabitants, produce, \&c. \&c. as delineated in the chart annexed.

2. An account of an expedition of discovery, made some years ago, by forty Christians, who had built a ship or vessel in the interior of Africa, and procceded down the river Cówara.

3. A geographical account of the country, rivers, lakes, \&c. from Bornou to Egypt, Nubia, Sennar, the Nile, its sources, \&c. \&c.

4. A traditional account of the people and country of Malí, \&c. \&c.

5. A traditional account of the origin of the Felan tribe, whom we have hitherto erroneously called "Fellatahs."

6. A traditional account of the people and country of Bargho, \&c. \&c.

7. An Itinerary, or the road from Sérá to Nubia, Sennar, and Egypt.

8. A traditional account of the people and country of Nefí, \&c. \&c.

9. A traditional account of the people and country of Noofy, \&c. \&c.

No. I.

The following is a translation of the Arabic which was written on the original chart (as Clapperton calls it), and of which the annexed is a reduced copy, professing to describe the course of the Cówara river, the road from Soccatoo to Maséna, and from Timbuctoo, with the names and geographical description of the towns and countries adjoining.

A. "Representation of the city of Soccatoo, metropolis of the Prince of the Believers (Sultan Bello)." 
B. "The island and town of Oodel or Goodel, together with the branch of the river which surrounds them."

C. "The town of Boory, two days' journey from Bagrá-foogal."

D. "The town of Bagrá-foogal, one day's journey from Ghagró."

E. "The town of Ghagró, three days' journey from 'Toondebí."

F. "The town of 'Toondebí, one day's journey from Sharif."

G. "The town of Sharif, three days' journey from Kasbi, or Kasb."

H. "The town of Kasbi, two days' journey from Seegho, or Sheeghó."

I. "The town of Seegho, or Sheeghó, one day"s journey from Kabará."

J. "The town of Kabará, half a day's journey from Timbuetoo."

K. "'The eity of Timbuetoo, ten days' journey from Jéri."

L. " Representation of the eity of Timbuctoo."

M. "The island and town of Jéri, together with the braneh of the river that sur. rounds them. This island is in the middle of the territory of Maséna, or Masera, and between it and Sego is seven days' journey."

N. "This braneh of the river is called, in the language of the Felan people, Bálió, and in Arabie the Black Sea or River. It extends from Jéri to Foota-Jaló."

O. "This branch is called by the Felans Ranioo, and in Arabie the White Sea or River. It extends from Maséna to Sego, Foota-toroo, and to Darhoz (perhaps San Salvador), one of the towns of the Freneh Christians."

P. "The road from Soecatoo to Maséna, which is frequented in these days, across the river and the island of Oodel, with the names and deseription of the towns and countries that are on it, between the river and Maséna.

"On the west bank of the river the country of Biténkoobi lies. Its inlrabitants are of the tribe of Felan; it abounds with mountains, rocks, plains, elephants, and buffaloes; and has along the bank of the river many white hills. Some of the people drink their water from the river, and others have shallow wells.

"Next to this, at one day's journey through an inhabited country, the territory of Maázo-moudi lies, whose inhabitants are of the tribe of Tooroodi. It is a low mountainous eountry, and abounds with thorny trees and wells. Its prinee is a tall and extremely strong man, and renowned for his eourage and wars."

Q. "Is the country of Yaghrá; between it and Maázo-moudi is about three days' journey, through desert and stony plains, with a few trees and some mountains. In the midst of the plains, however, there is a well-known river, ealled Sirba. Yaghra is now possessed by a prince of the Felans, named Ibrahim (Abraham) Boonti. It contains woods, small mountains, and a well-known deep river, ealled Yali, from which the people get their water."

R. "Is the eountry of Lebtakó; between it and Yaghrá is two days' journey, through woody plains and low ground. Its inhabitants are Felans, and its prinee is 
named Saléh. They are a great warlike people, possessing fine swift horses and many cattle. They subsist upon the corn called dokhun (millet); and their country is hilly and sandy, and has a large lake, called Dúry."

S. "Is the country of Jelghooji ; between it and Lebtakú is two days' journey, one of which is through villages, and the other through desert plains, in the midst of which there is a large lake, called Bookma. The king of this country is named Hamarkoli, and the people are Felans, and well known as great warriors. They possess abundance of swift horses, oxen, and other cattle. The country is mountainous, woody, and has a well-known lake, called Jeboo, besides a great many wells."

T. "Is the territory of Hajrí, one day's journey from Jelghooji. It is extensive, but very rocky, stony, and mountainous; has a great many sandy hills and a few vales; water in it is very scarce, and it has but few wells, so much so, that its inhabitants are obliged to store their water, during the rainy season, within the trunks of trees. The inhabitants of the vales are the Felans, who originally conquered these countries; but the mountains are inhabited by a people called Benoo-Hami (the children of $\mathrm{Fam}$ ), of the tribe of Sokai. They are great warriors, subsist upon the dokhun, and have abundance of swift horses and oxen. In the middle of this country there is a very great and lofty mountain, equal to which is not known in those parts, and here is its representation. [See $\triangle$ in the chart.] Upon it there is a town called Oonbori, whose king is named Noohoo-ghaloo-farma, of the tribe of Sokai, and is renowned for his generosity and munificence.

"All these countries, except Oonbori, are subject to our Lord the Prince of the Believers, Mohammed Bello, whom may God cause to be ever victorious, for the glory of the faithful, and the annihilation of the infidels."

U. “Is the territory of Maséna, seven days' journey from Hajrí: it is very extensive, fertile, and abounds with rivers and lakes. Its villages join both the old and modern ones of the Felans. Its imhabitants are powerful warriors, since ancient times possessing abundance of oxen and sheep, and are blessed with every comfort of food and living; most of them subsist upon rice, butter, fish, and meat. In the middle of the country there are two lofty mountains, called Soroba and Goran, and its cattle feed, throughont the four seasons of the year, upon grass; and as the lands are almost continually eovered with water, the shepherds and herdsmen gather the grass, heap it up in large stacks, and, while the cattle are grazing, live upon the tops thereof till the waters are dried up. Though this may appear marvellous, it is the fact with these people."

Nos. 1, 2, 3, and 4. "Are four rivers (perhaps canals) belonging to Maséna."

"The present Sultan of Maséna is Ahmad Hamad Labo, who rules over Timbuctoo, Jeri, and Oonbori, and indeed he may be called the sovereign of the Gharb (West) in Soodan. He is now at war with Sego,

"From Soccatoo to Benji is one day's journey through Sisilbi, which is the me- 
tropolis of Ghalooji. This country is level and fertile, and contains rivers, woods, gardens, and wells. On the east side of it there are two rocky, rugged mountains; on the right there is a river, and on the left there are plains and barren deserts. In the environs of the capital of Benji there are, however, several villages or towns belonging to the Mohammedans. Between the territory of Benji and that of Mouri is three days' and nights' journcy, through barren and sandy deserts. Mouri contains small mountains, woods, and has two roads on the left; on one of which there is a deep stream, and on the other are two lakes, surrounded with flowering and fruitful trees. This country originally belonged to the Sultan of Kabi, and its inhabitants are infidels. Its present sultan is named Ghagara, and has a city for his residence named Lukoo-you, which has a great lake near it. The chief towns of this country are Dogordoosi, Myzani, Toonsubi, and Tabada. There are many smaller ones, which need not be mentioned for brevity's sake. The lands are mostly stony, sandy, and hilly. 'There are a great many deep wells, well supplied with water; but the country altogether has but few trees, though it abounds with reptiles.

"Next to it, at two days' journey through dry deserts, with onc track of road oniy, though woody and hilly, the country of Emanoo lies, the first town of which is Bakendoosi, which is of a moderate size; and has, on the cast, a lake surrounded with trees; and, on the west, a well-known great and very tall tree. Between this town and the metropolis of the sultan, whose name is Aghmarak, is half a day's journey. Emanoo is part of the countries of the Tuaricks, and contains lakes, wells, mountains, hills, and sands. Its people live upon the dokliun, and possess a great many cattle.

"Next to this, at one day's journey, is the territory of 'Taghzar, which also belongs to the Tuaricks, and contains hills, wells, and natron lakes, which is called in our lan. guage káwa, or salt. East and west of this country therc are mountains well stocked with cattle. The people are the worst and most ill-disposed of the tribes of Tuarick; and their chief living is peas and dokhun. Their sultan is named Hama-ráwadó, and also Hama-zanzamá, which means in our language Dog.

"On the right of this country the territory of Jerma lies; it is a narrow vale, between high hills and hillocks of sand; and on the east it has a lofty mountain; it contains natron and other deep lakes. It is inhabited by the tribe of Benoo-Hami, who are great warriors, possessing swift and well-trained horses, and their spears are extremely long and wcll-ironed with sharp blades. They are ill-disposed people, and have no lawful sultan, but their chief is one chosen out of the tribe. They subsist mostly upon dokhun, and their country abuts on the great sea or river Cówara.

"On the left of the before-mentioned country ('Taghzar) that of Azwa lies, which is inhabited both by the Tuarick and by Benoo-Hami. It contains plains, vales, mountains, hills, and sands; and has deep streams. They possess abundance of cattle, and most of their living is the dokhun. 
"Between Taghzar and the river Cówara is three days' journey, through a barren desert, without any human being in it, inhabited only by wild beasts; and it has a long and deep stream ruming through sandy hills. From this stream the people of Taghzar provide themselves with water when they go to the chase of the giraffe in the winter season. The distance between their town and this stream is half a day's journey, through some woody plains, a few small mountains, and sandy hills. On the road, however, there is a small lake, surrounded with shrubs and trees, in which water is found only in the autumn.

"Near the river there are a great many white hills, without any trees upon them; but on the banks there are very large tall trees of tamarinds, under the shade of which travellers rest themselves.

W. "Now the great river Cówara comes, and here is its representation. This great river is the largest in all the territories of Houssa; we know not of its source, nor of any one who has seen it. It rushes and precipitates itself through the country from left to right, and contains many islands inhabited by fishermen, herdsmen, husbandmen, and settlers. As to the variety of its animals, birds, and fish, it is only known to the Lord Creator; it has rocks and mountains, which break and shatter to pieces all vessels that are driven against them; and its great roaring and noise, with the agitation of its waves, astonish the hearer and terrify the beholder; and, at the same time, exhibit the wonderful power of the Omnipotent Creator.

$\mathrm{X}$. "Is an undescribed branch of the river.

Y. "The writing of this copy ended on Thursday afternoon, the 5th of Rajab, 1242, of Hegira-(January 31, 182\%, A. D.), in the city of Soccatoo, residence of the Prince of the Faithful Sultan Mohammed Bello, by his special command to me, Mohammed, son of Ahmad Masané-(i.e. native of Maséna) - for Abdálláh the English Christian."

A. V. SALAMÉ.

No. II.

Translation of the Account of the "Expedition of Forty Christians," \& \&. \&c.

"In past years a company of Christians came from the side of Darwadar*, a town belonging to the Christians, following the river to Foota-tooro, and from thence they pro-

* It is perhaps Salvador. $-\mathrm{A} . \mathrm{S}$. 
ceeded to Ségo. They were forty men, and, on their arrival, the Sultan of Ségo received them hospitably, gave them presents, and lodged them in one of his towns ealled Sansaní (Sansanding of Park). They then aequainted him that they wished to build a ship; to do which he gave them leave. During their residence there, and the building of the ship, most of them died, and by the time the slip was finished, five only werc alive. These five men embarked on board the vessel, and proceeded eastwards till they arrived at Jeris, where they resided as long as God was pleased. They thence went on to Maséna, following the river till they came to one of our towns ealled Seebi *, between Jeri and Timbuctoo, that they might cross the way of the river $†$. They sojourned there with the prinee, who was one of the sons of the Sultan of Timbuctoo, and whose name was Babal-kydiali. He entertained them, and gave them leave to proceed to Timbuctoo. They continued their voyage till they arrived in safety, five as they were, at the eity of Timbuetoo, where they resided as long as God was pleased. Thence they went on towards the country of Soghy till they came to one of its towns called Gharwal-gáoo. There the Tuarieks met, and fought them severely till three were killed, and two only of them eseaped with the vessel.

"They proceeded towards the east till they arrived at Boussa; but the inhabitants fought and killed them, and their ship is to this moment there. This is the substanee and the truth of the case."

Observation.-From the melancholy termination of this adventure, and the place where the boat now exists, no one ean doubt that this account relates to Mungo Park and his party; and that it is the most authentic and circumstantial that can be had. As to their number being "forty Christians," it is easily aecounted for, when we know that those people call any one who might be in the service of an European "a Christian." So that it is not improbable that all those who were employed by Mungo Park were eonsidered "Christians," and thus formed the number of forty.

\section{A. V. S.}

- It should here be observed that the writer, who is the secretary of Sultan Bello, and wrote this by his order out of their records, is a native of Maséna.-A. S.

+ Whether this means the course, the current, or a reach of the river, I cannot make out. $-\mathrm{A} . \mathrm{S}$. 


\section{No. III.}

A Geographical Account of the Country, Rivers, Lakes, \&c. from Bornou to Egypt, \&c.

"The territory of Bornou is very extensive, and contains mountains, sands, and lakes: it has also two well known cities; one is called Sira, the other Kataghoon, whose prince is named Dankawa. To the name of Bornou that of Ghoodri is sometimes added.

"At twenty days' journey from Bornou the territory of Adamawá lies, which is moun. tainous, and contains vales, hills, and rivers. Two-thirds of its inhabitants are infidels, and one-third Felan Mahomedans. The metropolis of their sultan is called Ghórin. They possess plenty of horses and oxen, and subsist upon the dura (Indian corn). To the name of Adamawa the word Foobina is often added.

" Next to Adamawá, at two days' journey through a mountainous desert abounding with rivers, the country of Lúghwí (Loggun of Denham) lies; it contains a great many rivers, lakes, forests, and trees. Its inhabitants are Soodan Mahomedans; but the desert between it and Adamawá is infested with infidel robbers, who ride their horses without saddles, fight most desperately, often interrupt traffie on the road, and kill any one who falls into their hands.

"From Lúghwí to the territory of Baghármy, which comes next to it, is two days' journey through a desert containing a great and extensive fresh-water sea, ealled Asoor or Ashoo*. This country is hilly, sandy, and has small mountains; its width is a distance of ten days, and its length is mueh more. Its inhabitants are Soodan, Kahlans, and Arabs, who are robbers, and a treacherous set of people. Their sultan, whose name is Borkoomada, is as cruel as themselves, and even slays sheiks and Mahomedans. They possess abundance of lorses and oxen, get their water from wells, and subsist upon the dokhun.

" Next to Baghármy the country of Roogá lies, which is stony, abounding with rivers, and inhabited by infidels.

"At three days' journey through places inhabited by Arabs is the territory of Wadaí; it is very extensive, hilly, sandy, mountainous, and eontains vales, lakes, and deep wells. Its sultan is named Yousuf, and his eapital, whieh is situated under high mountains, is called Hoowara they are renowned for courage in war, swift horses, and the abundance of their camels, oxen, and sheep. They have a great many market places or towns, and their living is the dokhun and dura.

* This must be another name for the great lake Shad or Tchad.-A. S.-Perhaps rather the Asu river of Lander.-ED.

t The crown prince of Wadaí, if we can call him so, was last year in Egypt; and, upon his autho= rity, this country lies unler, or at the foot of, the Mountains of the Moon.-A.S. 
"Next to TVadai the country of Foor (Dar-foor) lies, at two days' journey through mountains and woody deserts, in the midst of which there is a vale containing dom trees. The territory of Foor is very extensive, hilly, sandy, and droughty, so much so, that, notwithstanding the great many deep wells they have, the people are obliged to preserve their water within the trunks of trees. They are a mixture of Felans, Arabs, and Kahlans; they possess plenty of swift horses, camels, oxen, and sheep; they have all sorts of warlike weapons, as shields, spears, armour, and so forth *, and are great warriors. Their sultan is named Mohammed Fadlú, who is a genteel, handsome, black man, and renowned for his munificence and generosity. His capital is called Nantalti, through which a river runs during the rainy season; but in winter the people are obliged to dig wells in the bed of that river for water. They live upon the dokhun and dura, and have some date gardens.

" At ten days' journey from Foor, through a mountainous, hilly, sandy, and droughty desert, is the country of the Kordofal, which extends seven days in length, and is inhabited by Arabs and Kahlans; it is however possessed now by the Turks + . It is very fertile, and has small mountains, hills, and sands; as also it contains fine horses, and plenty of cattle and asses. The capital of jts sultan is called Loobi, and the living of the people is the dokhun.

"Next to Kordofal is Sonnar, which is a ver'y extensive and fertile country; and its inhabitants, who are Arabs, are blessed with every sort of comfort by being able to cultivate the lands at all seasons of the year. 'This fertility is owing to the situation of the country being between two branches of the Nile; one of which, it is said, runs from the eastward, and the other, which is called the White river, runs from the westward; so that Sonnar is an island between the two rivers. It is, however, now in possession of the Turks $\neq$. It is a very cheap country, and its inhabitants possess plenty of oxen and asses, and subsist upon the dokhun.

"The White river becomes very full of water during the rainy season, which brings with it, from the Blue river, the animal called Anghorotú $§$; but during the summer it becomes so shallow as to be waded, the water not reaching above the thighs of people.

"Between Sonnar and Sawaken, which is on the Salt Sea coast (the Red Sea), is a distance of forty days."

A. S.

* When the present Pasha of Egypt sent his army to these countries, a few years ago, some of these pieces of armour and helmets were brought over to Cairo; and it was surprising to see them resembling, in every respect, those of the ancient Romans and Greeks.-A. S.

+ Mohammed Ali, the present Pasha of Egypt.-A.S.

$\ddagger$ See last Note.

$\S$ Whether this name is meant for the crocodile or hippopotanus I cannot say.-A. S. 


\section{Nos. IV. V. VI. VII. VIII. and IX.}

Traditional Account of different Nations of Africa, \&.c.

4. "The territory of Malee is extensive, contains a gold mine, and is inlabited by Soodans, whose origin is said to be from the remnants of the Copts. Among its inhabitants are also 'Towroods, Felans, Arabs, Jews, and Christians. These last are subject to two Christian sovereigns, who send their ships to the harbour of this place; and it is said that this country was formerly possessed by a people called Sarankali, who, it is presumed, were Persians.

"The kingdom of Malee is an ancient and flourishing country, and comprises two other provinces : one is Banbara, which contains rivers, woods, sands, a gold mine, and is occupied by the Soodan, who are still infidels, and possess great power; the other, on the west of it, is Foota, which is inhabited by the 'Towrood, and the Sarankali, or Persians. The Towrood people, it is said, were originally Jews, others say Christians; that they came from the land between the two rivers, the Nile* and the Euphrates, and established themselves next to the Jews who inhabited the island; and that whenever they oppressed or encroached upon the Jews, the latter had always recourse to the protection of the officers of the Sehabat (the immediate friends or companions of Mohammed), who then ruled over them; that they (the Jews) used to say to them: "We came to live in these islands to wait the coming of a prophet (after whom there will be no other); after whose coming and death a relation of his, named Aboo-Bakr, will succeed him ; and Aboo-Bakr's successor will be Amroo, whose troops will come upon the surface of this water (by which they meant Termes), protect us against you, and enable us to conquer your country $\uparrow$.'

"This is what we found written in our books."

N. B.-The above account, with the exception of the latter part, and a few small variations, has been already given to us in Sultan Bello's Geographical Account. (See Appendix, p. 166, First Journey.)

A. S.

5. "The origin of the Felan tribe is stated to be as follows: When the army of the Sehabat, during the reign of Omar Ben El-khattab, penetrated in to the Gharb, they arrived first at Termes; the Towrood people having seen them, went immediately under

* This is a mistake: it should be the Tigris.-A. S.

+ The inventor of this story had, there is no doubt, meant it to be as a prophecy for the coming of Mahomed, and that to show that even the Christians themselves had foretold his coming; for all these words which he puts into the mouth of these Christians are the very result of Mahomed's career, as recorded by the Mahomedan historians. $-A$. S . 
their protection, and became Mooslemeens, before the Jews who were waiting for them *; in eonsequenee of whieh they were enabled to fight and subdue the Jews and Sarankali (Persians). When the Sehabat wished their troops to retire from the Gharb, the prinee of the Towrood said to them: "You eame to us with a faith of whieh we were ignorant, and you are now going away without leaving any one to instruet us in it and its laws.' The Sehabat, hearing this appeal, left behind them, for their instruetion, Okbat Ben Aamer. He married a daughter of the prinee, named Gajmáa, and begot by her four sours, Dytá, Náser, Wáyá, and Rerebi. He afterwards returned to Egypt, and left his four sons behind with their mother. They grew up, and spoke a different language from that of their father, whieh was the Arabic, as well as from that of their mother, which was the old Towrood, ealled Wakoori. They married, and had sons and daughters, from whom the Felans deseended; so that the father of the Felans was an Arabian, and their mother' a 'Towrood.

"This we found recorded in our books $\uparrow . "$

6 "The eountry of Barghoo is situated on the right side of the river; it is woody and sandy, and inhabited by tribes of the Soodan, who, it is said, are deseended from the slaves of the Felans, who were left behind when their masters erossed the river; and thus they peopled those eountries. They are insubordinate and stubborn, as also very powerful in magie; and it is reeorded that, when the equitable Prinee Hadgi Mohamed Allah-kaja ruled over this province, he could gain no advantage over them.

"Next to Barghoo, the provinee of Ghoorma lies; it is extensive, mountainous, woody, sandy, and has various rivers. Its sultan is named Boojujú, and the inhabitants are almost of the same description as those of Barghoo, robbers, and depraved.

"On the west of Ghoorma, the country of Mooshier, or Mooshee, is situated. It is extensive, and eontains a gold mine, rivers, woods, and mountains. It is inhabited by tribes of the Soodan, who possess plenty of swift horses, very tall asses, and are very powerful in war. Their sultan is named Wagadoogo, and their asses are imported to Ghoonja to earry the drums of the army.

"On the right of Mooshér the territory of Asantí lies, whieh is very extensive."

N. B.-The above aecount, with the exeeption of a few small variations, has also been given to us in Sultan Bello's geographieal aceount. (See Appendix, p. 165-6, First Journey.)

* See No. 4.

+ Fgypt was conquered by the Mahomedans in the 20th year of Hegira, or the 10th after Mahomed's death, under the Khalifat of Omar Eben Elkattab, who, by the instigation of an intrepid officer named Amrú Ben El-Aàss (who, under some very singular circumstances, happened to visit Egypt and see its splendour a few years previous), sent an army, consisting of no more than 4000 men, to subdue that mighty and rich country. Amrú succeeded in his enterprise, and pushed on his conquest to the Gharb; but Okbat Ben Amer's name appears only as a witness to the treaties concluded between the conqueror and the people of Alexandria; though he was considered an officer of rank and valour.-A.S. 


\section{\%. Itinerary.}

"From Sira to Boogho is a distance of twenty days; thence to Mooshkoom-Foosh, to Sary, to Sarwa, to Indam or Indag, to Warshá, to Booshrá, to the mountain called Kaghoom, to Mount Kinghá, to Mount Dooziyat, to Mount Aboo-Talfan, to Mount Aboo-Zarafat ; then to Rooga, to Dygo, to Kájá, to Katoonú; then to the mountain of Nubia, to the gold mine called Tagly, which has no less than ninety-nine mountains, the name of each of which begins with $\mathrm{F}$; but three only of these mountains are known, whose names are as follow: Fazooglú, Fafaklú, and Foondooflú. In two days from this place, you will get to the Nile of Sonnar; but from 'Tagly to Egypt, or Cairo, which lies northward on the left side of it, is a journey of forty days, travelling continually by the bank of the Nile; while from Tagly to Sawaken, which is on the sea coast (the Red Sea), is a distance of thirty days only."

N. B.-This is the last of the seven papers which, it appears, were written in Captain Clapperton's memorandum book, by order of Sultan Bello, and are dated "the 5th of Shában, 1242, A.H;" about the 3d of March, 1827, A.D.

$$
\text { A. V. S. }
$$

8. "The people of Nefé came originally from Kashná, and their prince, Thoodyar, from Atághér. He first conquered the territory of Beni, from the river called Bakoo to that which is named Kaduná; then the territories of Booduor Boodi, and of Bassa or Boosa. He thence embarked on the river Kowárá, and subdued the people on its bank, called Abágha; after which he conquered the country of Abbi (in which we now are*), and that of Kanbari, in conjunction with the Prince of Yaouri. The river of these countries is called Kantagoora. From Yaouri he proceeded to the great mountain, or mountains, where Nefé, Beni, and Fatti-attu are: he then went to the river Katha, or Kasha, and conquered the countries thereabouts; which are, Ghoor-noofu, Koográ, Jemma, Doonfee, Taboo, and $\mathrm{Aza}_{3}$ or Azai. This prince was succeeded by Ithshab, whose successor was Ithkootoo; and the whole number of princes who ruled over this kingdom were thirteen. The rest of the eastern parts, as far as Katáná, are in possession of a prince named Bakoo.

" About the right of Atághér the country called Nafry lies, by the side of a river larger than that of Kowárá.

" The people of Beni are now extremely poor. They are submissive to their princes, till and cultivate the lands of others, and pay capitation tax. Sheep, goats, oxen, horses, and fowls, are scarce in their country; and as to asses, there are none, except what are imported from other countries. They have, however, plenty of elephants.

"The river in the territory of Kowára lies west, on the right hand side; and that of Kaduná is in the centre ; while the river Bakoo, or Gakoo, is in the east."

* The writer of this account, it seems, was in Captain Clapperton's company, or attached to his service.-A.S. 
9. "The tribes who inhabit Noofee, it is said, were originally from Beni ; others say from Takra; and some assert that they came from the middle of the river, perhaps an island. Their first town was Jemma; but afterwards they inhabited Kafath or Kifath, Ayaki, Karkena, and the eastern Kowárá, by a river ealled Matny. They had also Kasoo or Kashoo, Zeer, the west of Malee or Moulee, Abyou, and Wádá.

"The river of Kowárá runs through mountains, and a great many woods and forests; and has mountains on the north and the east. This great river issues from the Mountain of the Moon; and what we know of it is, that it eomes from Sookan to Kiya, to Kabi, to Yaouri, to Boossa, to Wá-wá, and to Noofee; but in that plaee there is another river which springs from Zirmá, to Ghoober, to Zeffra, to Kory or Koora, and then enters Noofee; its name is Kachuna. On the north of it Kanbari lies; on the east is Kory; on the south are Cankan and Kafath; and on the west is Bassoa, or Bashwa. About the eentre of it is the kingdom of Noofee, with that of Abyou.

"Noofee was once subjeet to the Felans; but when Edrees, a prince of the Felans, ruled over it, and eommitted so many exeesses as even to violate its virgins, the people rose up against him, sword in hand, and freed themselves; and thus they are now at war with the Felans. Amongst them there are Mahomedans; but the greater part are infidels, without either religion or law: they are drunkards and oppressors; they neither pray, nor worship any god. They walk with you during an hour as friends, while in the next they do not hesitate to kill you. When one of them dies, they fasten the arms aeross the chest, plaee the body in a sitting position in the grave, and one of them lies by it, while another sits at the entranee. They have a large and extensive eavern, in whieh they plaee their dead; but those who guard this eavern, though they are something like priests, are the most depraved persons. They sometimes send messengers to call the relatives of the dead, enjoining them to bring with them the best of every thing they have; and when these innoeent people arrive at the eavern, they are immediately plundered of what they take there; and if they be females, their ehastity is violated.

"This is the life and habits of these infidel Pagans; and consequently the roads about Noofee are very dangerous and perilous.

"When their king dies, they enter his house, and live in it."

N. B.-It is proper here to observe, that the above two papers, Nos. 8 and 9 , are written, or rather serawled out, unorthographieally and ungrammatieally, and their eomposition is no more than a sort of incoherent jargon. The translation, therefore, I have given of them is mostly made out by eonjecture. There is no doubt, however, that Clapperton, who made some residence among these people, has given some further account of them.

A. S. 
A VOCABULARY OF THE YOURRIBA TONGUE.

\begin{tabular}{|c|c|c|c|c|}
\hline Fowl, & Ade'a & & Mouth, & En'oo \\
\hline Goat, & Aoor'ey & & Teeth, & E'hee \\
\hline Sheep, & Agon'ta & & Ears, & Eff'ee \\
\hline Pig, & Ale'day & & Chin, & Ebb'ee \\
\hline Salt, & Ee'yo & & Neck, & Enaff'oo \\
\hline Corn, & Agbad'doo & & Sloulders, & Edgeookalı \\
\hline Millet, & Ok'kablebba & & Arm, & $\mathrm{Epk}^{\prime}$ wa \\
\hline Grass, & Co'co & & Elbow, & Ebah'wa \\
\hline Beads, & Le'key & & Wrist, & Onawa'wa \\
\hline Gold, & Sic'ca & & Hand, & $\mathrm{A}^{\prime}$ wa \\
\hline Coral, & In'yolı & & Thumb, & Atang'pako \\
\hline Silver, & Patak'ka & & Fingers, & Ama'wa \\
\hline Cloth, & Atchio & & The body, & Agwid'demoo'gu \\
\hline Man, & Okon'a & & Belly, & Inn'oh \\
\hline Woman, & Obin'a & & Thigh, & $\mathbf{E}^{\prime} \mathrm{tah}_{\mathbf{n}}$ \\
\hline King, & Ob'bah & & Knee, & Okk'oo \\
\hline Horse, & Ep'pee & & Leg, & Ajoo'goo \\
\hline Saddle, & Gar'ree & & Ankle, & Coco'sey \\
\hline Bridle, & Ja'noo & & Foot, & Atalis'sey \\
\hline Pepper, & Att'ah & & Toes, & Amalis'sa \\
\hline Shallots, & Allabous'sa & & Boots, & Sa'labattoo \\
\hline Yams, & Ish'oo & & Sandals, & Battoo \\
\hline Plantains, & Ayid'dey & & Fan, & Abab'bey \\
\hline Fire, & Jun'ah & & Cow, & Mall'oo \\
\hline Water, & Om'mee & & Dog, & $\mathrm{Aj}^{\prime} \mathrm{ah}_{\mathrm{h}}$ \\
\hline Wood, & Ig'gie & & Cub, & Aloghin'ne \\
\hline A pot, & Coc'co & & Mouse, & Acoo'fu \\
\hline A calabash, & E'bah & & Tiger, & Ek'ka \\
\hline Duck, & Pap'ayelı & & Hyena, & Eco'co \\
\hline Soup, & $\mathrm{Ob}^{\prime} \mathrm{eh}$ & & Vulture, & Awood'ce \\
\hline House, & Ill'eh & & Jacket, & Kook'oomah \\
\hline Mug, & Tank'ara & & Trousers, & Shock'ootoo \\
\hline Plate, & $A^{\prime}$ wo & & Turkey, & Fu'lutu'loo \\
\hline Knife, & O'belı & & Elephant, & Gen'acoo \\
\hline Head, & Or'ree & & Hippopotamus, & En'emy \\
\hline Eyes, & Oj'oo & 8 & Cotton wool, & $\mathrm{O}^{\prime}$ woo \\
\hline Nose, & Em'oo & & Palm oil, & Ep'eh \\
\hline
\end{tabular}




\begin{tabular}{|c|c|c|c|}
\hline Cocoa-nut, & Ay'ba & Five, & Mall'oo \\
\hline Tornado, & Oj'uma'ri & Six, & Mai'ffa mai'fa \\
\hline A mule, & Barak'ka & Seven, & Ma'gee \\
\hline A jackass, & Kettékettéh & Eight, & Ma'jo \\
\hline A mat, & Enn'ee & Nine, & Mai'ssu \\
\hline A bag, & Ok'key & 'Ten, & May'wah \\
\hline A gun, & E'bah & Twenty, & Ok'ko \\
\hline A cutlass, & Jom'ma & Thirty, & Agboug \\
\hline Silk, & Ce'dah & Forty, & Ogojee \\
\hline Damask & Ala'ri & Fifty, & Adett'a \\
\hline Scarlet cloth, & Doh'do & Sixty, & Ogotta \\
\hline Blue ditto, & Iss'ado'doh & Serenty, & Ado'nee \\
\hline Green ditto, & Alar'ooya'goo & Eighty, & Ogonee \\
\hline Yellow ditto, & & Ninety, & Adónoo \\
\hline Tree, & E'wajass'kway & One hundred, & Ogo'noo \\
\hline Sun, & O'noo & Two hundred, & Egbe'o \\
\hline Moon, & A joo'pa & Three ditto, & Oa'doo \\
\hline Star, & Era'wo & Four ditto, & In'ee \\
\hline God, & Ala'noo & Five ditto, & Edag'bett'a \\
\hline Thunder, & Ar'oo & Six ditto, & Eg'bett'a \\
\hline Lightning, & Mannumanu & Seven ditto, & Edag'be'ne \\
\hline Rain, & Odigoo & Eight ditto, & Eg'be'ne \\
\hline Wind, & Aroo'voo & Nine ditto, & Edegba'noo \\
\hline Cap, & Fill'ah & One thousand & Eggba'noo \\
\hline Hat, & Atte' Ebo & Two ditto & Ebah \\
\hline Hair, & Olloo & Three ditto & Egba'dagoo \\
\hline Beard, & Eg'bee & Four ditto & Egbagie \\
\hline Skin, & All'ah & Five ditto & Egbe'dogmoo \\
\hline Nail, & Eff'eh & Six ditto & Egbaa'ta \\
\hline One, & Ok'ka & Seven ditto & Edegbaa'nee \\
\hline Two, & Ma'jee & Eight ditto, & Egba'nee \\
\hline Three, & Mai'ta & Nine ditto, & Edegbaa'noo \\
\hline Four, & Me'ne & Ten ditto, & Ebaa'noo \\
\hline
\end{tabular}

FELLATAH.

$\begin{array}{llll}\text { One, } & \text { Go } & \text { Five, } & \text { Jowie } \\ \text { Two, } & \text { Diddie } & \text { Six, } & \text { Jowego } \\ \text { Tlıree, } & \text { Tattie } & \text { Seven, } & \text { Jowaddie } \\ \text { Four, } & \text { Ni } & \text { Eight, } & \text { Jowatittie }\end{array}$




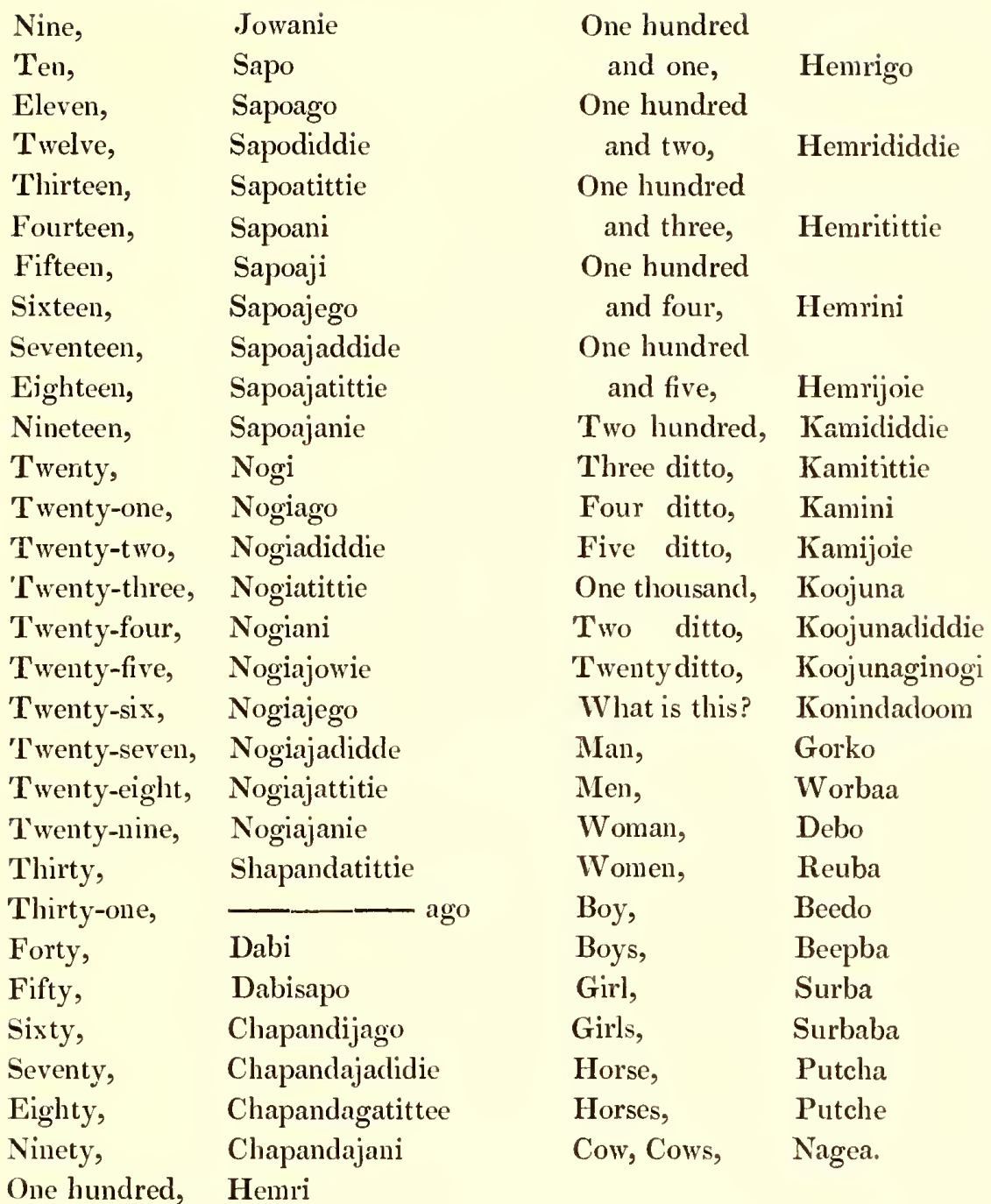


METEOROLOGICAL TABLE.

\begin{tabular}{|c|c|c|c|c|}
\hline Date. & Hours. & $\mathrm{Fah}^{\dagger}$ 。 & Bar. & \\
\hline 1825. & & & & BADAGRY. \\
\hline \multirow[t]{3}{*}{ Dec. 2} & 6 A.M. & $80^{\circ}$. & $99^{\circ} .813$ & Calm and hazy. \\
\hline & Noon. & 91 & .705 & South-west winds. \\
\hline & 3 P.M. & $91 \frac{1}{2}$ & .653 & \\
\hline \multirow[t]{3}{*}{3} & $6 \mathrm{~A} . \mathrm{M}$. & 78 & .912 & Cloudy and calm. \\
\hline & Noon. & 92 & .631 & South, fine breezes. \\
\hline & 3 P.M. & 91 & .515 & \\
\hline \multirow[t]{3}{*}{4} & $6 \mathrm{~A} . \mathrm{M}$. & $7 \%$ & .854 & Calm. \\
\hline & Noon. & 90 & .568 & Soutl, fine breeze. \\
\hline & 3 P.M. & 90 & .532 & Moderate. \\
\hline \multirow[t]{3}{*}{5} & 6 A.M. & 79 & .786 & Thin showers. \\
\hline & Noon. & 89 & .623 & South-east, fine breezes. \\
\hline & 3 P.M. & 86 & .578 & Cloudy, thick weather. \\
\hline 6 & 6 A.M. & 76 & .899 & Thin rain, light breezes, and cloudy. \\
\hline 1826 & Noonti. & DO & ש & Chiado. \\
\hline \multirow[t]{2}{*}{ Jan. 10} & 3 P.M. & 89 & 28.700 & Hazy. \\
\hline & & 85 & .700 & South south-west light air. \\
\hline \multirow[t]{5}{*}{11} & 6 A.M. & 75 & .750 & Calm and clear. \\
\hline & & 82 & .750 & Same. \\
\hline & Noon. & 90 & .695 & Light airs. \\
\hline & 3 P.M. & 94 & .675 & Ditto and clear. \\
\hline & & 90 & .675 & Koosoo. \\
\hline \multirow{4}{*}{15} & 6 P.M. & 89 & .800 & Calm. \\
\hline & 6 A.M. & 75 & & Strong breezes, east hy north Harmattan. \\
\hline & Noon. & 89 & & \\
\hline & 3 P.M. & 90 & .709 & \\
\hline \multirow[t]{5}{*}{20} & 1 P.M. & 91 & .696 & \\
\hline & & 91 & & \\
\hline & 3 & 93 & .646 & North north-east strong Harmattan. \\
\hline & 4 & 92 & & \\
\hline & 5 & 84 & & Katunga or Eyeo. \\
\hline \multirow[t]{3}{*}{25} & 6 A.M. & 83 & 28.640 & North north-west, clear. \\
\hline & Noon. & $89 \frac{1}{2}$ & .580 & Strong breeze, fine, north-east. \\
\hline & 3 P.M. & 90 & .549 & East. \\
\hline \multirow[t]{3}{*}{26} & 6 A.M. & 70 & & Clear, light breezes, and cool. \\
\hline & & 83 & .587 & Fresh breezes, north north-east. \\
\hline & Noon. & 89 & .524 & Light ditto. \\
\hline & 3 P.M. & 90 & .519 & Mild ditto. \\
\hline \multirow{4}{*}{ Feb. 3} & Noon. & 81 & .552 & Tube broke. \\
\hline & 6 A.MI. & 74 & .560 & Dull and hazy. \\
\hline & 9 & $\begin{array}{l}82 \\
89\end{array}$ & .516 & \\
\hline & & & .000 & \\
\hline
\end{tabular}




\begin{tabular}{|c|c|c|c|c|}
\hline Date. & Hours. & Faht. & Bar. & \\
\hline 1826. & & & & Katunga or Eyeo. \\
\hline \multirow[t]{3}{*}{ Feb. 4} & 6 A.M. & $79^{\circ}$ & $28^{0} .510$ & \\
\hline & & 89 & .510 & \\
\hline & $\begin{array}{l}\text { Noon. } \\
3 \text { P.M. }\end{array}$ & 89 & 458 & \\
\hline 5 & $\begin{array}{l}3 \text { P.M. } \\
6 \text { A.M. }\end{array}$ & 77 & .458 & Thunder storm. \\
\hline \multirow{4}{*}{6} & 6 A.M. & 77 & .510 & Cloudy, and strong breeze. \\
\hline & $\begin{array}{l}0 \\
9\end{array}$ & 89 & .458 & Fresh breeze and clear. \\
\hline & Noon. & 91 & .500 & Moderate breézes. \\
\hline & 3 P.M. & $91 \frac{1}{2}$ & .488 & Calm and clear. \\
\hline \multirow[t]{4}{*}{7} & 6 A.M. & 78 & .500 & Fresh breeze during the night. \\
\hline & & 88 & .555 & Moderate, north-east. \\
\hline & Noon. & 94 & .517 & Calm. \\
\hline & 3 P.M. & 91 & .480 & Light airs. \\
\hline \multirow[t]{4}{*}{8} & 6 A.M. & 75 & .552 & Light airs and hazy. \\
\hline & & 84 & .611 & Ditto and flying clouds. \\
\hline & Noon. & 89 & .568 & Mild, east-north-east. \\
\hline & 3 P.M. & 90 & .484 & \\
\hline \multirow[t]{4}{*}{9} & 6 A.M. & 72 & .497 & Fresh breeze, clear and cool, south-west. \\
\hline & & 87 & .521 & West-north-west. \\
\hline & Nooll. & 91 & & Light airs. \\
\hline & 3 P.M. & 89 & .449 & Calm. \\
\hline \multirow[t]{4}{*}{10} & 6 A.M. & 76 & .524 & Moderate and clear. \\
\hline & & 82 & .568 & West-north-west, flying clouds. \\
\hline & Noon. & 92 & .515 & Light airs, east-north-east. \\
\hline & 3 P.M. & 88 & .475 & \\
\hline \multirow[t]{3}{*}{11} & $\begin{array}{l}6 \text { A.M. } \\
9\end{array}$ & $\begin{array}{l}75 \\
85\end{array}$ & $\begin{array}{l}.535 \\
.543\end{array}$ & Light breezes and clear. \\
\hline & Noon. & 90 & .472 & \\
\hline & 3 P.M. & 93 & .455 & Calm. \\
\hline \multirow[t]{4}{*}{12} & 6 A.M. & 76 & .506 & Fresh breezes, north-west. \\
\hline & & 86 & .544 & Light airs. \\
\hline & Noon. & 92 & .509 & Squally, north-east. \\
\hline & 3 P.M. & 94 & 420 & Fresh breeze. \\
\hline \multirow[t]{4}{*}{13} & 6 A.M. & 78 & .472 & Strong breeze and cloudy. \\
\hline & & 86 & .540 & Moderate and cloudy, north-east. \\
\hline & Noon. & 97 & .475 & Light airs and clear. \\
\hline & 3 P.M. & 94 & .435 & Ditto and cloudy. \\
\hline \multirow[t]{4}{*}{14} & 6 A.M. & 80 & .505 & Strong breeze and cloudy. \\
\hline & & 84 & .550 & Moderate breeze. \\
\hline & Noon. & 91 & .504 & Light airs. \\
\hline & 3 P.M. & $94 \frac{1}{2}$ & .440 & Cloudy-midnight, fresh breeze and \\
\hline \multirow[t]{3}{*}{15} & $\begin{array}{l}6 \text { A.M. } \\
9\end{array}$ & $\begin{array}{l}75 \\
84\end{array}$ & $\begin{array}{l}.537 \\
.591\end{array}$ & S cloudy. \\
\hline & Noon. & $\begin{array}{l}84 \\
91\end{array}$ & $\begin{array}{l}.591 \\
.539\end{array}$ & Clear and moderate. \\
\hline & 3 P.M. & $91 \frac{1}{2}$ & .420 & \\
\hline \multirow[t]{2}{*}{16} & 6 A.M. & 80 & .590 & K Harmattan from north_east all day \\
\hline & 3 P.M. & 91 & .537 & 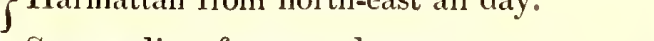 \\
\hline 17 & 6 A.M. & 74 & 612 & Strong ditto from north-east. \\
\hline
\end{tabular}




\begin{tabular}{|c|c|c|c|c|}
\hline Date. & Hours. & Faht. & Bar. & \\
\hline 1826. & & & & Katunga or Eyeo. \\
\hline \multirow[t]{3}{*}{ Feb. 17} & 9 A.M. & $83^{\circ}$ & $28^{\circ} .696$ & \\
\hline & Noon. & 89 & .628 & \\
\hline & 3 P.M. & $89 \frac{3}{4}$ & .568 & \\
\hline \multirow[t]{4}{*}{18} & 6 A.M. & 75 & .600 & Harmattan from north-east. \\
\hline & 9 & 84 & .708 & \\
\hline & Noon. & 89 & 635 & \\
\hline & 3 P.M. & 92 & .515 & \\
\hline \multirow[t]{3}{*}{19} & 6 A.M. & 70 & .500 & (Strong Harmattan from north-east, with \\
\hline & Noon. & 84 & .534 & thick fog. \\
\hline & 3 P.M. & 88 & .426 & \\
\hline \multirow[t]{4}{*}{20} & 6 A.M. & 70 & .510 & \\
\hline & & 82 & .580 & \\
\hline & Noon. & 88 & .530 & Harmattan continued. \\
\hline & 3 P.M. & 88 & .475 & \\
\hline \multirow[t]{3}{*}{21} & 6 A.M. & 70 & .568 & \\
\hline & Noon. & 80 & .602 & The same. \\
\hline & 3 P.M. & 89 & .572 & \\
\hline \multirow[t]{4}{*}{22} & 6 A.M. & 70 & .520 & \\
\hline & & 80 & .580 & The same. \\
\hline & Noon. & 85 & .534 & \\
\hline & 3 P.M. & 86 & .460 & \\
\hline \multirow[t]{4}{*}{23} & 6 A.M. & 70 & .535 & \\
\hline & & 79 & .552 & The same. \\
\hline & Noon. & 84 & .520 & \\
\hline & 3 P.M. & 86 & .482 & \\
\hline \multirow[t]{2}{*}{24} & 6 A.M. & 69 & .515 & CThe same. \\
\hline & & $\begin{array}{l}78 \\
88\end{array}$ & .571 & \\
\hline \multirow{4}{*}{25} & $\begin{array}{l}\text { Noon. } \\
6 \mathrm{~A} . \mathrm{M} \text {. }\end{array}$ & 72 & .442 & \\
\hline & & 80 & .571 & The same \\
\hline & Noon. & 88 & .510 & 1 \\
\hline & 3 P.M. & 89 & .430 & \\
\hline
\end{tabular}

AT VARIOUS PLACES ON THE ROUTE.

\begin{tabular}{|c|c|c|c|c|}
\hline $\begin{array}{c}\text { Week, Mo. } \\
\text { Days. }\end{array}$ & $\begin{array}{c}\text { Time of } \\
\text { observation. }\end{array}$ & $\begin{array}{c}\text { Therm. } \\
\text { Faht. }\end{array}$ & Barometer. & REMARKS, \&c. \\
\hline $\begin{array}{c}1826 . \\
\text { March } 14\end{array}$ & $\begin{array}{l}\text { Noon. } \\
3 \text { P.M. } \\
6 \\
6 \text { A.M. } \\
9 \\
\text { Noon. } \\
3 \text { P.M. } \\
6 \\
6 \text { A.M.M. }\end{array}$ & $\begin{array}{l}94 \\
94 \\
91 \\
78 \\
88 \\
91 \\
94 \\
91 \\
74\end{array}$ & $\begin{array}{l}.580 \\
.634 \\
.604 \\
.510 \\
.548 \\
.586\end{array}$ & $\begin{array}{l}\text { \{ City of Kiama in Borgoo. Fresh breezes and } \\
\text { clear, wind north-east. } \\
\text { Fresh breezes, wind east-north-east. } \\
\text { Fresh breezes, with light flying clouds. } \\
\text { The same. } \\
\text { Calm and cloudy. } \\
\text { Calm, with light clouds. }\end{array}$ \\
\hline
\end{tabular}




\begin{tabular}{|c|c|c|c|c|}
\hline $\begin{array}{l}\text { Week, Mo. } \\
\text { Days. }\end{array}$ & $\begin{array}{c}\text { Time of } \\
\text { observation. }\end{array}$ & $\begin{array}{l}\text { Therm. } \\
\text { Faht. }\end{array}$ & Barometer. & REMARKS, \&c. \\
\hline \multirow{6}{*}{$\begin{array}{r}\text { March } 15 \\
16\end{array}$} & 9 A.M. & $85^{\circ}$ & $28^{\circ} .651$ & Light breezes from the east-north-east. \\
\hline & Noon. & 91 & .610 & The same, with light flying elouds. \\
\hline & 3 P.M. & 93 & .550 & The same. \\
\hline & & 91 & .540 & The same. \\
\hline & 6 A.M. & ry & .595 & Light airs and elear, wind-north-east. \\
\hline & 9 & 82 & .696 & $\left\{\begin{array}{l}\text { Freshening breezes, with a slight haze, wind } \\
\text { north-east. }\end{array}\right.$ \\
\hline \multirow[t]{2}{*}{17} & Noon. & 89 & .625 & Moderate and hazy. \\
\hline & 3 P.M. & 91 & .575 & Hazy and sultry, with little wind. \\
\hline \multirow[t]{12}{*}{ April 7} & 8 A.M. & 86 & .411 & $\left\{\begin{array}{l}\text { dom of Borgoo, about } 50 \text { feet above the river } \\
\text { Quorra, on the west bank. }\end{array}\right.$ \\
\hline & 9 & 89 & $.37 \%$ & $\{$ Fresh breezes from the eastward, with a slight \\
\hline & & $89 \frac{1}{2}$ & .400 & Cloudy, with fresh breezes. \\
\hline & Noon. & $93^{2}$ & .375 & The same. \\
\hline & 3 P.M. & 90 & & Strong breezes, and dark cloudy weather. \\
\hline & & 89 & .300 & Moderate breezes, with dark eloudy weather. \\
\hline & 6 A.M. & 179 & 29,320 & $\left\{\begin{array}{l}\text { Dull eloudy weather, with little wind from the } \\
\text { south-west. }\end{array}\right.$ \\
\hline & 9 & 82 & .368 & The same. \\
\hline & Noon. & 90 & .375 & The same. \\
\hline & 3 P.M. & 99 & .320 & Clear, with light airs from the south-west. \\
\hline & & 93 & .280 & Calm and clear. \\
\hline & 10 A.M. & 89 & 29.85 & $\left\{\begin{array}{l}\text { Town of Tabra in Nyffe. Cloudy, with mode- } \\
\text { rate breezes, wind south-west. }\end{array}\right.$ \\
\hline \multirow[t]{5}{*}{17} & Noon. & 95 & 60 & The same, with light flying clouds. \\
\hline & 3 P.M. & 98 & .45 & Moderate breezes. \\
\hline & & 91 & 28.992 & Calm, with light elouds. \\
\hline & 6 A.M. & \% 4 & $.96 \%$ & City of Tabra in Nyffé. Calm with light elouds. \\
\hline & & 86 & 29.80 & Light breezes, flying elouds, wind south-west. \\
\hline \multirow[t]{4}{*}{18} & Noon. & 96 & 28.920 & Moderate breezes, with light clouds. \\
\hline & $\begin{array}{l}3 \text { P.M. } \\
6\end{array}$ & $\begin{array}{l}97 \frac{1}{2} \\
9 j^{2}\end{array}$ & .866 & Light airs, wind south-west. \\
\hline & 6 A.M. & 80 & .943 & Dull and cloudy, with fresh breezes. \\
\hline & & 88 & 29.11 & Fresh breezes, wind south-west. \\
\hline 19 & 3 P.M. & 97 & 28.953 & Moderat \\
\hline \multirow{8}{*}{ July 5} & 4.M.M. & 80 & 27862 & f Light airs and eloudy, with thunder and light- \\
\hline & & & & \\
\hline & 6 A.M. & 73 & .986 & $\left\{\begin{array}{c}\text { Moderate breezes, with dark cloudy weather, } \\
\text { wind south-west. }\end{array}\right.$ \\
\hline & 9 & 78 & .942 & Light airs and eloudy. \\
\hline & Noon. & 85 & .985 & The same, with light flying elouds. \\
\hline & 3 P.M. & 85 & .940 & Light breezes, with thunder clouds to eastward. \\
\hline & & 84 & .952 & Light airs and eloudy. \\
\hline & 6 A.M. & 75 & 28.011 & $\left\{\begin{array}{l}\text { Dull and eloudy, with light breezes from the } \\
\text { south-west. }\end{array}\right.$ \\
\hline
\end{tabular}




\begin{tabular}{|c|c|c|c|c|}
\hline $\begin{array}{l}\text { Week, Ho. } \\
\text { Days. }\end{array}$ & $\begin{array}{c}\text { Time of } \\
\text { observation. }\end{array}$ & $\begin{array}{l}\text { Therm. } \\
\text { Faht. }\end{array}$ & Barometer. & REMARKS, \&c. \\
\hline 1826. & & & & \\
\hline \multirow{4}{*}{$\begin{array}{r}\text { July } 6 \\
7\end{array}$} & 9 A.M. & $7 \%$ & $28^{\circ} .067$ & A little rain, with light airs from the south. \\
\hline & Noon. & 85 & .124 & Moderate, with thiek elouds. \\
\hline & 3 P.M. & & 28. & The same, wind south-west. \\
\hline & 10 A.M. & 79 & 27.917 & $\begin{array}{l}\text { Zegzeg. Dull and eloudy, with light airs from } \\
\text { the soutl. }\end{array}$ \\
\hline \multirow[t]{5}{*}{12} & Noon. & 81 & .888 & Light airs, with dull eloudy weather. \\
\hline & 3 P.M. & 83 & .858 & The same, wind south-west. \\
\hline & & 81 & .985 & Cloudy. \\
\hline & 6 A.M. & 75 & 28.820 & Cloudy, with a fresh breeze. \\
\hline & & 78 & .820 & The same. \\
\hline \multirow[t]{5}{*}{13} & Noon. & 84 & .815 & Cloudy, with light dull airs from the south. \\
\hline & 3 P.M. & 85 & .780 & $\left\{\begin{array}{l}\text { Moderate breezes and cloudy, thunder clou } \\
\text { to the south-east. }\end{array}\right.$ \\
\hline & 6 & 80 & .785 & Calm. \\
\hline & 6 A.M. & 75 & .805 & $\left\{\begin{array}{l}\text { Fresh breezes and eloudy from the east, with } \\
\text { low elouds. }\end{array}\right.$ \\
\hline & 9 & $8 \%$ & .842 & Fresh breezes, and dark eloudy weather. \\
\hline \multirow[t]{3}{*}{14} & Noon. & 80 & .781 & $\left\{\begin{array}{l}\text { Strong breezes and squally, with thick el } \\
\text { weather, wind west. }\end{array}\right.$ \\
\hline & 3 P.MI. & 82 & .751 & Thiek cloudy weather. \\
\hline & 6 & 80 & .735 & $\left\{\begin{array}{l}\text { Moderate breezes, with dull eloudy weather, } \\
\text { wind south-west. }\end{array}\right.$ \\
\hline 17 & 6 P.M. & 74 & 27.765 & $\left\{\begin{array}{l}\text { A single observation taken at the town of } \\
\text { Aushin, provinee of Zegzeg. Dull eloudy } \\
\text { weather, with a fresh breeze from the west- } \\
\text { south-west. }\end{array}\right.$ \\
\hline \multirow[t]{3}{*}{20} & 10 A.M. & 75 & $\cdot 438$ & $\left\{\begin{array}{l}\text { Town of Baebaegie, provinee of Kano. Calm } \\
\text { and eloudy, with a little rain. }\end{array}\right.$ \\
\hline & Noon. & 78 & .354 & Fresh breezes and eloudy, wind south-west. \\
\hline & $\begin{array}{l}3 \text { P.M. } \\
6\end{array}$ & $\begin{array}{l}80 \\
80\end{array}$ & .289 & $\begin{array}{l}\text { Light airs and eloudy. } \\
\text { Calm and eloudy. }\end{array}$ \\
\hline \multirow[t]{4}{*}{ Aug. 9} & 3 P.M. & $85 \frac{1}{2}$ & 23.252 & $\left\{\begin{array}{c}\text { City of Kano. Fresh breezes and eloudy, threat- } \\
\text { ening rain. }\end{array}\right.$ \\
\hline & & 81 & .237 & Moderate breezes and cloudy, wind south-east. \\
\hline & $6 \mathrm{A.M}$ & 76 & .269 & Light breezes with rain. \\
\hline & & $78 \frac{1}{2}$ & .269 & Fair ; at 10 A.M. rain. \\
\hline \multirow[t]{5}{*}{10} & Noon. & 79 & .251 & $\left\{\begin{array}{l}\text { Fresh breezes from the south-west, with rain; } \\
\text { at } 1 \text { P.M. fair. }\end{array}\right.$ \\
\hline & 3 P.M. & 79 & .199 & Fresh gales and eloudy, wind west-south-west. \\
\hline & & 78 & & S Moderate and eloudy, wind south; it had rained \\
\hline & 6 A.M. & 76 & .192 & a all night. \\
\hline & 9 & $79 \frac{1}{2}$ & .234 & Fresh breezes and eloudy, wind soutl-west. \\
\hline \multirow[t]{2}{*}{11} & Noon. & 81 & .212 & $\left\{\begin{array}{l}\text { Fresh gales, with tying clouds, and a tew drops } \\
\text { of rain. }\end{array}\right.$ \\
\hline & & 84 & .202 & $\left\{\begin{array}{c}\text { Fresh gales and eloudy, rain, heavy thunder } \\
\text { clouds. }\end{array}\right.$ \\
\hline
\end{tabular}




\begin{tabular}{|c|c|c|c|c|}
\hline $\begin{array}{l}\text { Weekr MIo. } \\
\text { Days. }\end{array}$ & $\begin{array}{c}\text { Time of } \\
\text { observation. }\end{array}$ & $\begin{array}{l}\text { Therm. } \\
\text { Faht. }\end{array}$ & Barometer. & REMARKS, \&c. \\
\hline & & & & \\
\hline \multirow{3}{*}{ Aug. 11} & 6 P.M. & $80^{2}$ & 28.227 & Moderate breczes, with light clouds. \\
\hline & $6 \mathrm{A.M}$ & 76 & .320 & $\begin{array}{l}\text { Light airs, } \\
\text { cloudy. }\end{array}$ \\
\hline & 9 & 79 & .371 & Fresh breezes and cloudy, wind west-south-west. \\
\hline \multirow[t]{4}{*}{12} & Noon. & 83 & .346 & $\left\{\begin{array}{l}\text { Fresh breezes and cloudy, thunder and rain, } \\
\text { wind south-west. }\end{array}\right.$ \\
\hline & 3 P.M. & $82 \frac{1}{2}$ & .305 & Fresh breezes and cloudy, with a light hazc. \\
\hline & 6 A.M. & $\begin{array}{l}81 \\
78 \frac{1}{2}\end{array}$ & $\begin{array}{l}.280 \\
.344\end{array}$ & $\begin{array}{l}\text { Light airs and light clouds. } \\
\text { Light breczes, cloudy, wind south-south-wcst. }\end{array}$ \\
\hline & & 81 & .375 & $\{$ Moderate and cloudy, with slight rain at times; \\
\hline \multirow{5}{*}{13} & Noon. & 176 & .318 & 2 at \\
\hline & 3 P.M. & 1979 & .273 & $\begin{array}{l}\text { Heavy rain, thumde } \\
\text { Light winds and he }\end{array}$ \\
\hline & & 79 & .240 & Moderate breezes and cloudy. \\
\hline & 6 A.M. & 75 & .291 & $\{$ Moderate and clear, with light flying clouds; \\
\hline & & 79 & .368 & Fresh breezes and cloudy, threatening rain. \\
\hline \multirow[t]{4}{*}{14} & Noon. & $82 \frac{1}{2}$ & .311 & Woderate breezes, with clouds and suushine. \\
\hline & 3 P.M. & $86 \frac{1}{2}$ & .220 & Moderate and fine, wind south-west. \\
\hline & 6 & 84 & .270 & ariable, with dark cloudy weather, thunder \\
\hline & 9 A.M. & 178 & .364 & Fresh breczes and cloudy, wind south-west. \\
\hline \multirow[t]{5}{*}{15} & Noon. & 83 & .344 & Moderate breezes, with light white clouds, wind \\
\hline & 3 P.M. & 85 & .270 & The samc. \\
\hline & & 86 & .246 & Light airs and fine. \\
\hline & 6 A.M. & 73 & .325 & $\begin{array}{l}\text { with thunder, lightning, aud rain; during the } \\
\text { night a tornado. }\end{array}$ \\
\hline & 9 & 79 & .337 & $\left\{\begin{array}{l}\text { Modcrate and cloudy, with a light haze, wind } \\
\text { south-west. }\end{array}\right.$ \\
\hline \multirow[t]{3}{*}{16} & Noon. & $83 \frac{1}{2}$ & .329 & Fresh breczes and cloudy from the south-ivest. \\
\hline & 3 P.M. & 85 & .269 & \\
\hline & 6 & $83 \frac{\pi}{2}$ & .329 & Moderate breezes, with light flying clouds. \\
\hline
\end{tabular}

HEIGHT OF THERMOMETER IN KANO, AS OBSERVED BY RICHARD LANDER, AUGUST 25, 1826.

95. Dull morning, 6 A.M. ; 12 noon, clear ; 3 P.M. clear

26. A thunder storm and heavy rain; 12 noon, dull ; 3 P.M. do. $\quad 75 \quad 79 \quad 79$

2\%. 6 A.M. clear light air ; 12 noon, clear; 3 P.M. clcar $\quad . \quad 76 \quad 81 \quad 84$

28. Clear at 6 A.M. ; 12 noon, calm and cloudy; 3 P.M. light airs $777 \quad 81 \quad 85$

29. 6 A.M. heavy rain; 12 noon, clear and calm; 3 P.M. clear and calm $73 \quad 82 \quad 83$

30. 6 A.M. clear; 12 noon, a thunder storm and heavy rain $\quad \begin{array}{rrrr}72 & 79 & 79\end{array}$

31. Clear and cold; 12 noon, clear and cold . . $\quad \begin{array}{cccc}73 & 80 & 84\end{array}$ 
1. Dull morning; 12 noon, dull; 3 P.M. dull and cloudy

8. Dull morning; 12 noon, clear ; 3 P.M. clear

$\begin{array}{lll}76 & 83 & 82\end{array}$

10. Dull morning; 12 noon, dull; 3 P.M. heavy rain

$\begin{array}{lll}79 & 80 & \% 9\end{array}$

11. Clear and calm

$\begin{array}{lll}77 & 85 & 86\end{array}$

12. Clear and caln

$\begin{array}{lll}80 & 85 & 86\end{array}$

13. Clear and light air

$\begin{array}{lll}79 & 84 & 83\end{array}$

14. Clear and light air

15. Clear and light air

$\begin{array}{lll}79 & 86 & 85\end{array}$

16. Clear and light air

$\begin{array}{lll}80 & 85 & 86\end{array}$

1\%. Clear and light air

18. Clear until noon; 3 P.M. a thunder storm and rain

$79 \quad 86 \quad 83$

19. Clear and ealm

$\begin{array}{lll}78 & 84 & 88\end{array}$

20. Clear and calm until 3 P.M. and light air

21. Clear and ealm

22. Clear and calm until 12 noon, light air

23. Clear, light air

24. Clear and ealm; 12 noon, and light air

25. Clear and calm

26. Clear; 12 noon, light breezes

$78 \quad 84 \quad 87$

2\%. Clear, light air

28. Clear; 12 noon, light rain

$77 \quad 84 \quad 88$

$\begin{array}{lll}76 & 85 & 88\end{array}$

$\begin{array}{rrr}79 & 90 & 90\end{array}$

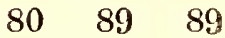

$79 \quad 86^{\circ} \quad 88$

$\begin{array}{lll}79 & 86 & 89\end{array}$

$\begin{array}{lll}79 & 86 & 89\end{array}$

29. Cleal; 3 P.M. heavy rain

$80 \quad 86 \quad 90$

30. Dull and foggy; 3 P.M. heavy rain and wind

$\begin{array}{lll}79 & 86 & 89\end{array}$

$\begin{array}{lll}79 & 85 & 87\end{array}$ Oct.

1. Heavy rain and a thunder storm

$\begin{array}{lll}70 & 76 & 79\end{array}$

2. Clear and cold, light breezes

$\begin{array}{lll}\% 0 & 80 & 80\end{array}$

3. Clear and cold, light breezes

$\begin{array}{lll}70 & 83 \quad 85\end{array}$

4. Clear, light air, and cold

5. Clear and light breezes

71 $84 \quad 84$

$70 \quad 83 \quad 85$

6. Clear and ealm

$\begin{array}{lll}80 & 88 & 88\end{array}$

\%. Clear, light air

$\begin{array}{lll}80 & 87 & 87\end{array}$

8. Clear and calm

9. Clear and light breezes

$75 \quad 89$ 89

10. Clear and light breezes

$\begin{array}{lll}80 & 87 & 88\end{array}$

11. Clear and ealm

7588 88

12. Clear and fine breezes

13. Clear, light air

$\begin{array}{lll}75 & 87 & 87\end{array}$

$\begin{array}{lll}75 & 88 & 88\end{array}$

$\begin{array}{lll}76 & 89 & 89\end{array}$

14. Clear, light breezes

24. Clear and eold

$\begin{array}{lll}76 & 87 & 87\end{array}$

25. Clear light breezes

$\begin{array}{lll}75 & 86 & 86\end{array}$

$\begin{array}{lll}75 & 83 \quad 8 \%\end{array}$ 
Oct.

26. Clear and cold, light air

27. Clear and eold, light air

28. Clear and cold, light breezes

29. Clear and light breezes

30. Clear; 12 at noon, light breeze from east

31. Clear; 12 noon, light breeze

Nor.

1. Clear and calm

2. Clear; 12 noon, light air

3. Clear; 12 noon, light breeze

4. Dull and hazy

5. Clear; 12 noon, a light breeze

6. Clear; 12 noon, light breeze

7. Clear; 12 noon, light breeze

8. Clear at $8 ; 12$ noon, hazy and light breeze

9. Clear at $9 ; 12$ noon, cloudy, and light breeze

10. Clear at $8 ; 12$, light breezes

11. Clear at $9 ; 12$, light breezes

12. Clear at $8 ; 12$, light breezes

13. Clear at $9 ; 12$, light air

14. Clear; 12, light breezes

15. Clear; 12 at noon, a light breeze

16. Clear; 12, light breezes

17. Clear; 12 noon, a light breeze

18. Clear; 12 noon, a light air

19. Clear; 12 noon, a light breeze

20. Clear, strong breeze, wind east

21. Clear, light breezes
6 A.M. Noon. 3 P.M.

$75^{\circ} \quad 84^{\circ} \quad 83^{\circ}$

$\begin{array}{lll}75 & 87 & 86\end{array}$

$\begin{array}{lll}75 & 85 & 85\end{array}$

$\begin{array}{lll}75 & 86 & 85\end{array}$

$\begin{array}{lll}75 & 84 & 85\end{array}$

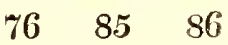

$76 \quad 84 \quad 85$

$\begin{array}{lll}76 & 88 & 88\end{array}$

$\begin{array}{lll}76 & 85 & 86\end{array}$

$\begin{array}{lll}76 & 86 & 86\end{array}$

$\begin{array}{lll}75 & 87 & 86\end{array}$

$\begin{array}{lll}75 & 85 & 86\end{array}$

$\begin{array}{lll}75 & 85 & 86\end{array}$

$\begin{array}{lll}75 & 85 & 86\end{array}$

$75 \quad 86 \quad 8 \%$

$\begin{array}{lll}75 & 88 & 88\end{array}$

$7585 \quad 86^{\circ}$

$\begin{array}{lll}77 & 86 & 87\end{array}$

$76 \quad 85 \quad 86$

$\begin{array}{lll}75 & 85 & 87\end{array}$

$\begin{array}{lll}75 & 86 & 86\end{array}$

$76 \quad 84 \quad 85$

$\begin{array}{lll}77 & 85 & 87\end{array}$

$\begin{array}{lll}76 & 86 & 86\end{array}$

$76 \quad 85 \quad 85$

$\begin{array}{lll}75 & 85 & 85\end{array}$

$75 \quad 89 \quad 89$

\section{SOCKATOO, JANUARY \%, $182 \%$}

Jan.

7. Strong breeze from east-riorth-east, clear . $\quad \begin{array}{lllll}\text { 7. } & 70 & 90 & 92\end{array}$

8. Monday, 6 A.M. light breeze, hazy; 12 noon, wind east-north-east $\% \quad 90 \quad 92$

9. 6 A.M. eold and elear, a strong wind east-north-east; 12, elear, light air

10. 6 A.M. eold and hazy; 12 , strong breezes, clear, north-east wind; 3 P.M. clear . . . . . . 60

11. Cold and hazy; 12, a fine breeze, wind north-east, elear, light breeze $62 \quad 89 \quad 90$ 
12. 6 A.M. cold and hazy; 12, light breeze, wind north-east, clear; 3 P.M. clear . $\quad . \quad$. $\quad . \quad$. $\quad . \quad 6 \quad 64^{\circ} 86^{\circ} 85^{\circ}$

13. Clear and cold, wind north-east; 12 at noon, clear and cold ; 3

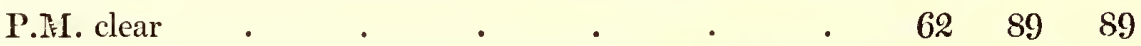

14. 6A.M.hazy, calm; 12, strong breezes, wind north-east;3P.M.clear 62 $88 \quad 88$

15. Clear, cold, wind north-east; 12, strong breezes; 3 P.M. clear $\quad \begin{array}{llll}62 & 86 & 86\end{array}$

16. Clear and cold, wind north-cast, strong breeze, clear; 3P.M. clear $60 \quad 80 \quad 80$

1\%. Hazy calm; 12 noon, strong breeze and clear, wind north-east $\quad \begin{array}{llll}62 & 80 & 80\end{array}$

18. Thureday, clcar and cold, wind north-east; 12 noon, clear, strong $\begin{array}{llllllll}\text { breeze, wind north-east } & 0 & 0 & 0 & 0 & 62 & 81 & 83\end{array}$

19. Clear and cold, a strong breeze from north-east $\quad . \quad \begin{array}{lllll} & \text {. } & 65 & 84 & 86\end{array}$

20. Clear; 12 at noon, strong breeze, wind east, 3 P.M. clear . $\quad 64 \quad 68 \quad 89$

21. Sunday, clear and calm; 12 noon, light breeze, wind east ; 3

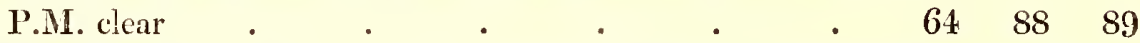

29. Morning hazy, a light air; 12 noon, clear, light breeze, wind east $62 \quad 89 \quad 90$

23. Morning hazy ; 12 noon, light breeze and clear, wind north-east $\begin{array}{llll}65 & 90 & 93\end{array}$

24. IVednesday, morning hazy, calm; 12 noon, clear, fine breeze, $\begin{array}{lllllllll}\text { east ; } 3 \text { P.M. clear } & 0 & . & 0 & 0 & 0 & 72 & 96 & 98\end{array}$

25. Morning lazy, calm; 12 noon, clear, a light breeze, wind east; 3 P.M. clear . . . . . . . . 70

26. Hazy, calm; 12 noon, clear, a light breeze, wind north-east;

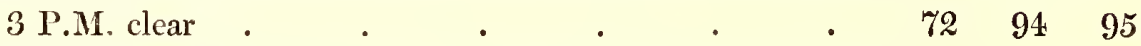

2\%. Morning hazy and calm; 12 noon, light breezes, clear, wind $\begin{array}{llllllll}\text { north-east ; } 3 \text { P.M. clear } & 0 & 0 & 0 & 0 & 63 & 9 & 9\end{array}$

28. Morning hazy and calm; 12 noon, light breeze; 3 P.M.clear, wind

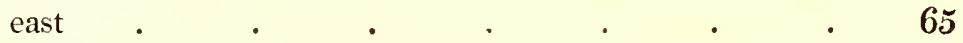

2). Morning clear, a light air; 12 noon, light breeze, clear, wind east ; 3 P.M. clear . . . . . . 75

30. Hazy and a light air; 12 noon, clear, light breeze, wind north-east;

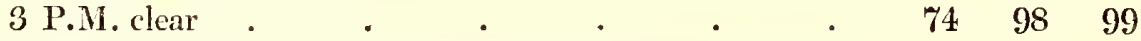

31. Wednesday, clear; 12 noon, clear, light breezc, wind south-east; 3 P.M. clear . . . . . . . 75

1. Thursday, morning hazy and calm; 12 noon, light breeze, wind south-east, clear; 3 P.M. clear . . . . . 75

2. Morning hazy and calm; 12 noon, a light breeze, wind northeast; 3 P.M. clear . . . . . . 75

3. Morning hazy and calm; 12 noon, light breeze, wind north-east; 3 P.M. clear 
Feb.

6 A.M. Noon. 3 P.M.

4. Sunday, morning hazy and calm; 12 noon, light breeze and clear, $\begin{array}{lllllllllll}\text { wind north-east } & 0 & 0 & 0 & 75^{\circ} & 98^{\circ} & 99^{\circ}\end{array}$

5. Morning hazy and calm; 12 noon, light breeze, clear, wind north-east $75 \quad 100 \quad 104$

20. Morning hazy and calm; 12 noon, light breeze, clear, wind ditto $75 \quad 95 \quad 100$

21. Morning hazy; 12 noon, light breeze and clear, wind north-east $75 \quad 100100$

22. Thursday, morning hazy; 12 noon, light breeze and clear, wind $\begin{array}{lllllllllll}\text { north-east } & 0 & 0 & 0 & 0 & 75 & 100 & 100\end{array}$

23. Morning hazy; 12 noon, light breeze and clear, wind north-east $7 \% \quad 100 \quad 100$

24. Saturday, morning hazy; 12 noon, light breeze, clear, wind

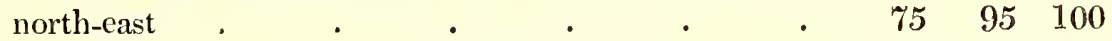

25. Morning hazy; 12 noon, a fine breeze, wind north-east . $\quad 75 \quad 100 \quad 100$

26. Morning hazy, calm; 12 noon, light breeze, wind north-east;

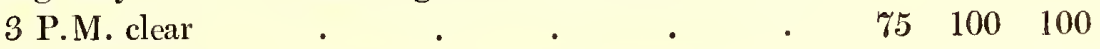

2\%. Tuesday, morning hazy, calm; 12 noon, light breeze, clear,

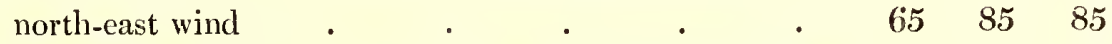

28. Strong gales, hazy; 12 noon, strong gales; 3 P.M. strong gales, north-east wind . $\quad . \quad$. $\quad . \quad$.

During a whirlwind at 2 P.M. the thermometer fell from $100 \frac{\mathrm{r}}{2}$ to 98 , and at 3 P.M. rose to 101 .

March.

1. Strong gales during the day, and hazy, north-east wind $\begin{array}{llll}\text { 1. } & 85 & 85 & 100\end{array}$

2. Strong gales and hazy during the day, north-east wind $\begin{array}{lllll}65 & 85 & 85\end{array}$

3. Strong gales and cloudy during the day, north-east wind - $\quad \begin{array}{llll}65 & 85 & 85\end{array}$

4. Sundry light breezes during the day, north-east wind $\begin{array}{lllll}\text { 4. } & 74 & 89 & 90\end{array}$

5. Morning hazy; 12 noon, light breezc, north-east $\quad \begin{array}{llll}72 & 95 & 98\end{array}$

6. Calm and hazy; 12 noon, clear, east wind; 3 P.M. hazy, light air $71 \quad 96 \quad 96$

7. 6 A.M. hazy, calm; 12 noon, cloudy, a light breeze, east wind;

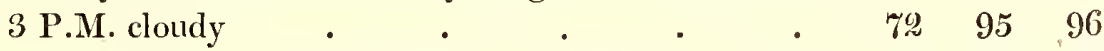

8. Hazy, calm ; 12 noon, hazy, a light breeze; 3 P.M. hazy, light air $70 \quad 96 \quad 95$

9. Friday, 6 A.M. hazy, calm; 12 noon, light breeze, clear, east

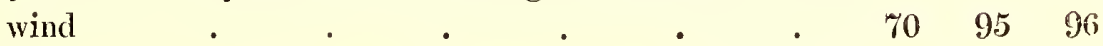

10. 6 A.M. hazy and calm; 12 noon, strong breeze, clear; 3 P.M. clear . . . . . . . . . . $\%$

11. Hazy and calm; 12 noon, a light breeze, clear; 3 P.M. clear,

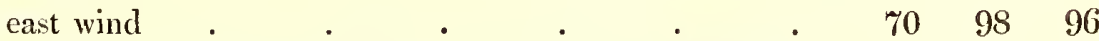

12. Hazy and calm; 12 noon, fine breeze and clear, east wind $\quad 70 \quad 95 \quad 96$

13. 6 A.M. strong breeze, south-by-east wind; 12 noon, strong breezes, south-by-east wind ; 3 P.M. a fine breeze $\begin{array}{lllll}70 & 99 & 97\end{array}$

14. Hazy, light air; 12 noon, strong breeze, south-by-east wind, clear $70 \quad 95 \quad 96$ 
March.

6 A.M. Noon. 3 P.II.

15. Hazy and calm; 12 noon, strong breezes, south-by-east wind, clear; 3 P.M. clear $70^{\circ} \quad 96^{\circ} 95^{\circ}$

16. Light breeze and hazy; 12 noon, light breeze and clear; 3 P.M. clear

\%0 $100 \quad 98$

1\%. Hazy and calm; 12 noon, a light breeze, clear, east-north-east wind; 3 P.M. clear . . . . .

$70 \quad 98 \quad 99$

18. Sunday, calm and hazy; 12 noon, light breeze and clear, east wind .

$70 \quad 100 \quad 100$

19. 6 A.M. calm and clear; 12 noon, calm and clear; 3 P.M. light wind .

20. Calm and clear; 3 P.M. a light breeze, west wind

$73 \quad 101 \quad 101$

21. Calm and clear until 3 P.M., a fine breeze, west wind

71102102

75102103

92. 6 A.M. calm and clear; 12 noon, a strong breeze, east wind

$75 \quad 104 \quad 105$

23. 6 A.M. calm and clear; 12 noon, light breeze; 3 P.M. light breeze, clear

$74 \quad 101 \quad 100$

24. 6 A.M. calm and hazy; 12 noon, light breeze, hazy; 3 P.M.

44 $\quad 100 \quad 100$

25. Sunday, 6 A.M. calm and hazy; 12 noon, hazy, light breeze, east wind

26. 6 A.M. a clear light breeze; 12 noon, hazy, a light breeze, east wind; 3 P.M. a light breeze

$74 \quad 101 \quad 100$

2\%. 6 A.M. a light breeze; 12 noon, hazy, a light breeze, east wind; 3 P.M. light breeze

$73 \quad 104 \quad 101$

98. 6 A.M. light breeze; 12 noon, a light breeze, clear, south-east

$72 \quad 100 \quad 100$

99. 6 A.M. strong breeze, clear, south-east wind; 12 noon, light air ; 3 P.M. light air

72 $99 \quad 100$

30. 6 A.M. hazy, a light air ; 12 noon, hazy, a light breeze, east wind; 3 P.M. a light air

12 $101 \quad 100$

31. 6 A.M. hazy, a light south-east wind; 12 noon, hazy, light south-east wind; 3 P.M. hazy, light air

$57 \quad 106 \quad 105$ April.

1. Sunday, sultry and hazy, calm; 12 noon, sultry and hazy .

$74 \quad 101 \quad 102$

2. Hazy during the day, light air . . . . . . $\quad \begin{array}{lllll}70 & 101 & 105\end{array}$

3. Hazy and calm; 19 noon, light breeze, south-east wind, light air 74 $103 \quad 107$

4. Calm and hazy; 12 noon, light breeze, south-west wind; 3 P.M.

$\begin{array}{lllllllllll}\text { hazy, light breeze } & 0 & 0 & 0 & 0 & 78 & 104 & 104\end{array}$

5. A dull hazy day, light breezes . . . . . . $\quad \begin{array}{llll}78 & 110 & 108\end{array}$

6. Dull and hazy; 3 P.M. a light breeze from west . $\quad . \quad 7 \% \quad \begin{array}{rrr}700 & 100\end{array}$ 
April.

7. Dull and hazy ; 3 P.M. light breezes, south-west wind

8. Sunday, dull and hazy, light air during the day .

9. Clear day and light breezes, south-west wind .

10. Tuesday, clear day and light breezes, south-west wind

11. Clear, and light breezes from the south-west

12. Clear morning, and light breezes 3 P.M.

14. Clear morning, calm; 12 noon, light breezes, south-west wind

15. Clear morning, calm; 3 P.M. light breezes, south-west wind, clear

16. 6 A.M. misty and calm; 12 noon, light breezes, south-west wind ; 3 P.M. light breezes, south-west wind .

1\%. 6 A.M. misty, west wind; 12 noon, light air; 3 P.M. calm and misty

23. 6 A.M. clear morning, a fine breeze from the west; 3 P.M. calm .

24. Cloudy day; a fine breeze from the west

25. Cloudy and calm; 12 noon, a strong breeze from the west; 3 P.M. calm and clear; 6 P.M. a thunder storm

26. Clear and calm; 12 noon, light breeze from the west, and clear; 3 P.M. calm and misty

27. Clear and calm; 12 noon, light breeze from the west; 3 P.M. clear .

28. Clear morning, light air; 12 noon, a fine breeze from the west; 3 P.M. fine breeze

29. Sunday, morning clear and calm; 12 noon, cloudy, light breeze; 3 P.M. a gale of wind, with thunder storm

30. Morning calm and clear; 12 noon, light breeze from the west; 3 P.M. light breezes and clear May.

1. Tuesday, cloudy during the day, light breeze from the west
6 A.M. Noon. 3 P.M.

$79^{\circ} \quad 100^{\circ} 100^{\circ}$

77 $102 \quad 103$

$\begin{array}{lll}77 & 103 \quad 104\end{array}$

$\begin{array}{lll}77 & 104 & 107\end{array}$

$\begin{array}{lll}79 & 104 & 103\end{array}$

$7 \% \quad 104 \quad 104$

$\begin{array}{lll}77 & 105 & 106\end{array}$

$\begin{array}{lll}80 & 105 & 106\end{array}$

$79 \quad 106 \quad 106$

$\begin{array}{lll}80 & 109 & 108\end{array}$

$\begin{array}{lll}76 & 105 & 106\end{array}$

$\begin{array}{lll}79 & 102 & 103\end{array}$

$78 \quad 102 \quad 104$

$\begin{array}{lll}79 & 103 \quad 105\end{array}$

$\begin{array}{lll}78 & 105 \quad 106\end{array}$

$\begin{array}{lll}78 & 103 & 105\end{array}$

$76 \quad 100 \quad 90$

$\begin{array}{lll}78 & 100 & 100\end{array}$

$\begin{array}{lll}77 & 100 & 10 z\end{array}$ 






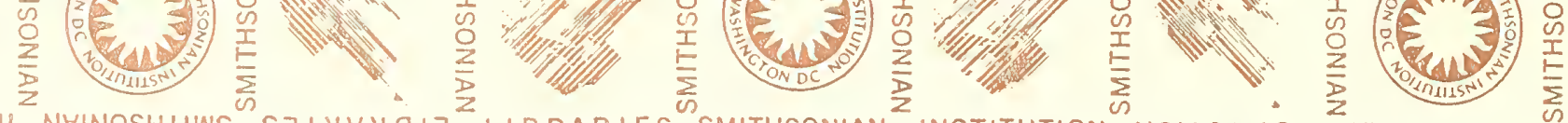

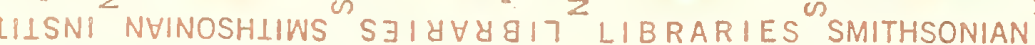
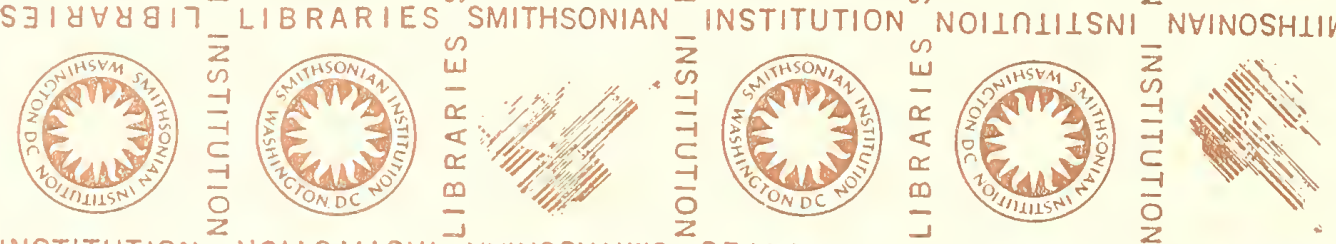

$s^{n}$
s
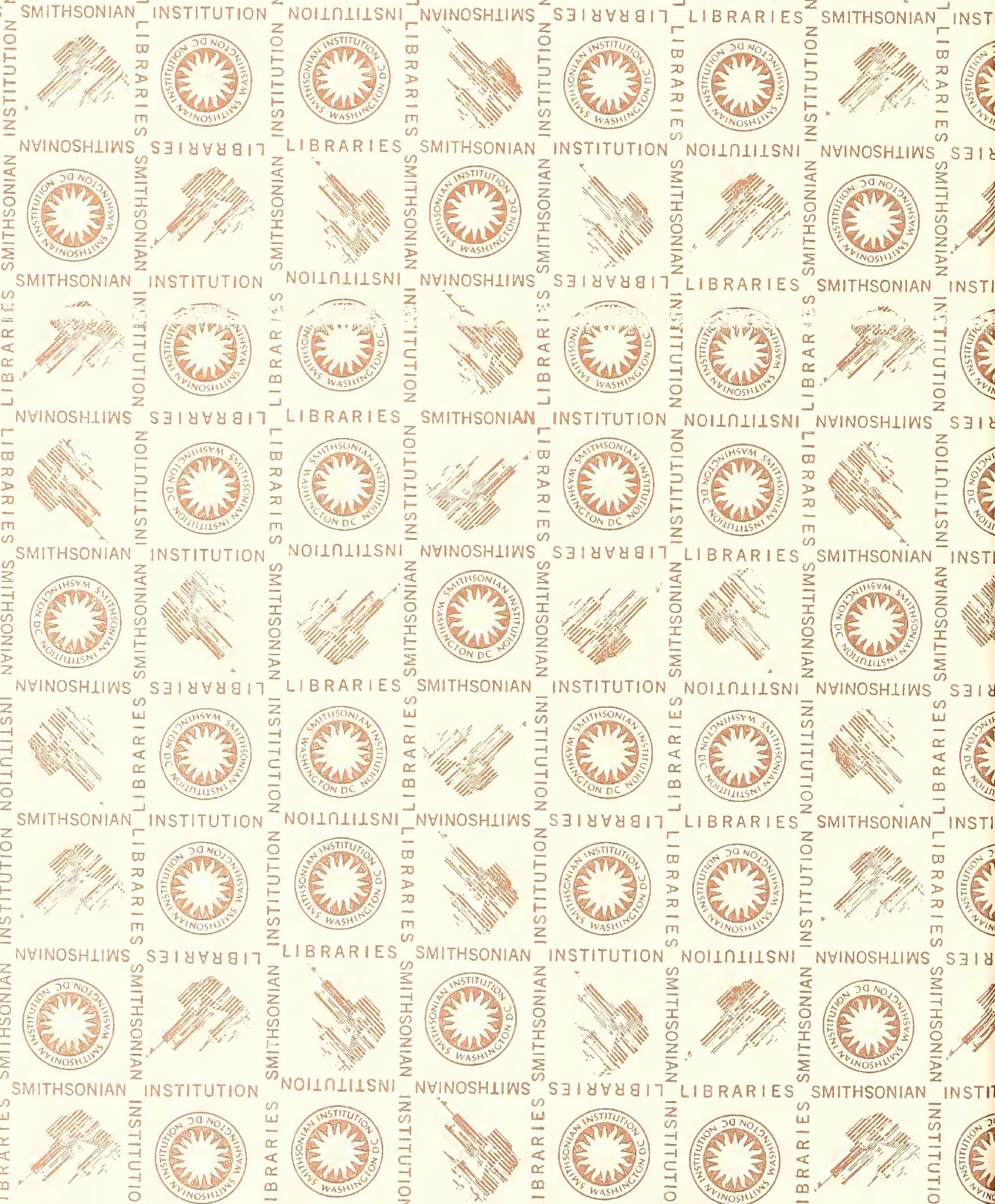

LIBRARIES SMITHSONIAN INSTII 
